\title{
RENDA: DESIGUALDADE E POBREZA NO ESTADO DO PIAUÍ
}

\author{
JAÍRA MARIA ALCOBAÇA GOMES \\ Economista
}

Orientador: Prof. Dr. RODOLFO HOFFMANN

Tese apresentada à Escola Superior de Agricultura "Luiz de Queiroz", Universidade de São Paulo, para obtenção do título de Doutor em Ciências, Área de Concentração: Economia Aplicada.

\section{PIRACICABA}

Estado de São Paulo - Brasil

Julho - 1998 
Gomes, Jaíra Maria Alcobaça

Renda: desigualdade e pobreza no Estado do Piaui / Jaíra Maria Alcobaça Gomes.

- - Piracicaba, 1998.

$187 \mathrm{p}$.

Tese (doutorado) - - Escola Superior de Agricultura Luiz de Queiroz, 1998.

Bibliografia.

1. Condição sócio-econômica 2. Desenvolvimento econômico 3. Distribuição de renda 4. Economia aplicada 5. Pobreza I. Título 
"Conquistemos o inédito, porém o possivel"

\section{Paulo Freire}

"Todo mundo sonha em realizar grandes coisas, mesmo quando estas grandes coisas possam apenas carregar a marca duma felicidade nas pequenas coisas que realizam".

\section{Frei Neylor J. Tonin}

Para meu filho, 


\section{AGRADECIMENTOS}

Agradeço

Ao apoio e à amizade dos meus pais Salvador e Jesus, das minhas irmãs Jussara e Giane, e a Pedinha, pela paciência.

Ao apoio doméstico da Eliana, Regina, Milcíades, Sílvia, Valdo e Taniana, em Piracicaba.

Aos amigos Lysia e Antônio de Pádua Santos (Departamento de Economia/UFPI) e Marta (Departamento de História), pelo incentivo e indicação bibliográfica.

Ao Ricardo Ribeiro, Chefe do Departamento de Economia, pelo apoio material.

À Pró-Reitoria de Pesquisa e Pós-Graduação, através do PICD/UFPI, pela concessão da bolsa de estudo (CAPES).

Ao Airton Sampaio, pela revisão de linguagem, à Regina Silva, pela orientação na normalização e ao Soares, pela encadernação.

Aos colegas da pós-graduação Estevão e Regina, pelo material emprestado. 
Aos funcionários do DESR/ESALQ, Maielli, Lú, Cris, Helena e Márcia, pelo atendimento das minhas necessidades burocráticas, como cópias, livros, etc.

Aos professores do DESR/ESALQ, Geraldo Barros e José Carlos Caetano Bacha, pela confiança depositada em meu trabalho, e aos professores Paulo Cidade e Oriowaldo Queda, pelas sugestões e críticas durante o processo de elaboração da tese.

Ao Professor Orientador Rodolfo Hoffmann, cujo exemplo acadêmico reconheço, deixo meu muito obrigado pelos ensinamentos, críticas e sugestões durante todo o Curso de Doutorado (disciplinas e tese). 


\section{SUMÁRIO}

Página

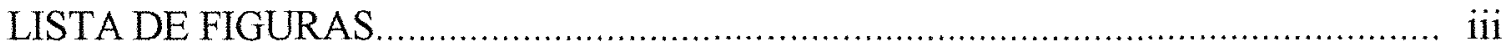

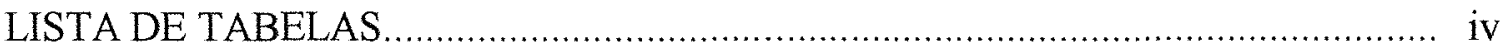

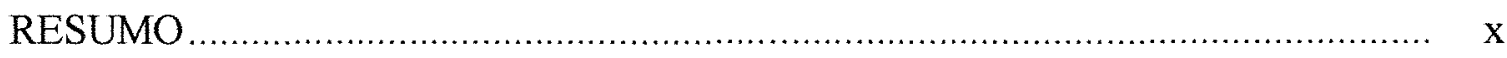

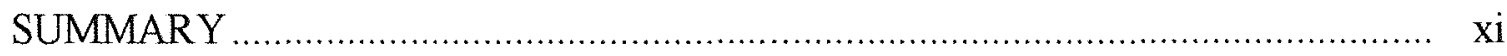

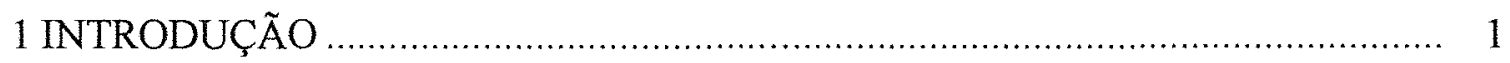

2 RENDA E DESENVOLVIMENTO HUMANO ….......................................... 5

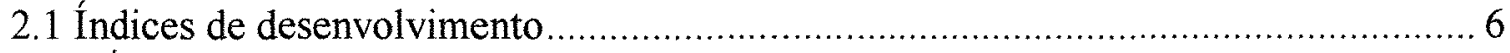

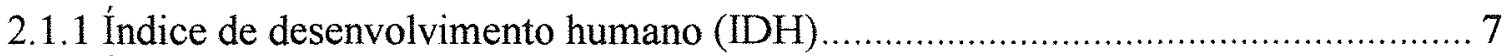

2.1.2 Índice de desenvolvimento social (IDS) ….............................................. 10

2.1.3 Índice de bem-estar social para a agricultura (IBES) …................................. 12

2.1.4 Os índices de desenvolvimento social e humano para o Estado do Piauí ............. 13

2.2 Fatores explicativos da distribuição da renda no Brasil ........................................ 18

2.2.1 Controvérsia sobre a distribuição da renda na década de $1970 \ldots \ldots \ldots \ldots \ldots \ldots \ldots \ldots . . . . . . .19$

2.2.2 Condicionantes da distribuição da renda nas décadas de 1980 e 1990 ................ 22

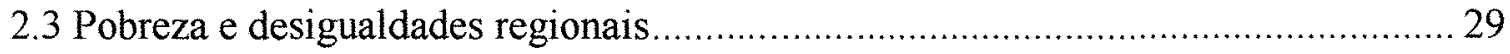

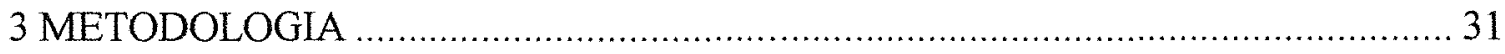

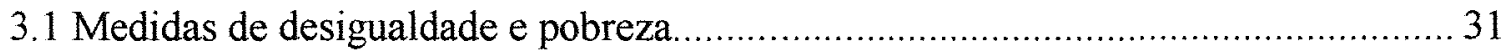

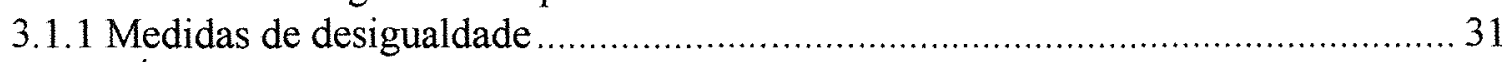

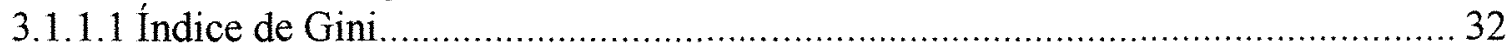

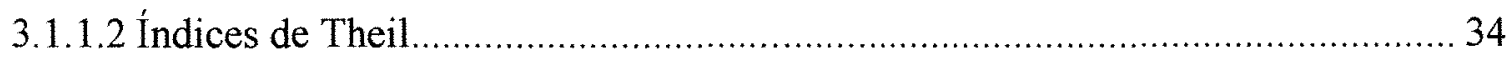

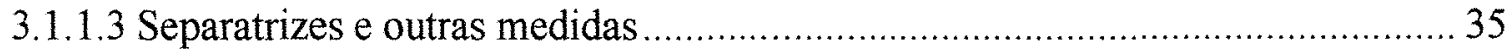




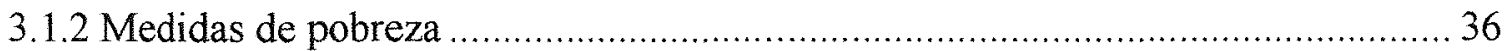

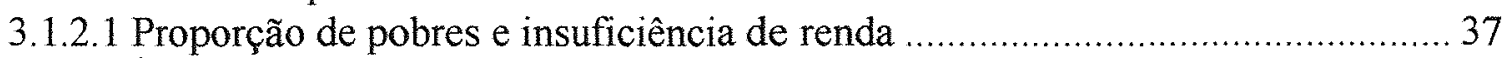

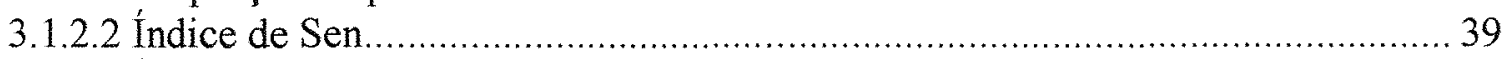

3.1.2.3 Índice de Foster, Greer e Thorbecke ........................................................ 40

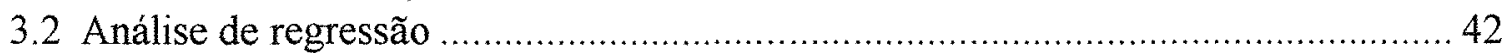

3.3 Escolha das variáveis e limitações dos dados..................................................... 43

4 DISTRIBUIÇÃO DA RENDA E POBREZA NO ESTADO DO PIAUI: 1960,1970 e

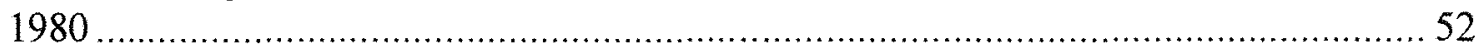

4.1 Configuração da distribuição da renda e pobreza nas décadas de 1960,1970 e

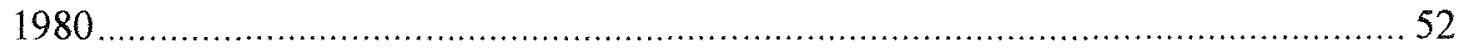

4.2 A desigualdade e a pobreza em 1980: análise dos dados individuais.................... 61

4.2.1 Condicionantes sócio-demográficos e econômicos da desigualdade da distribuição da renda 66

5 DESIGUALDADE E POBREZA NO PIAUÍ: ANOS 90 ..................................... 73

5.1 Evolução da distribuição da renda e pobreza no período de 1984 a 1996 .............. 74

5.1.1 Relação funcional entre pobreza, desigualdade e renda média ........................... 86

5.1.2 Relação funcional entre pobreza, desigualdade e inflação ............................... 88

5.2 Desigualdade econômica e pobreza absoluta em 1992, 1993 e 1995: análise

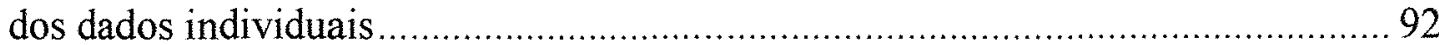

5.2.1 A desigualdade da distribuição da renda ................................................... 114

5.2.2 Componentes estruturais da desigualdade da distribuição da renda ................. 123

5.3 Grau da pobreza absoluta no Estado do Piauí................................................... 138

5.3.1 Fatores contribuintes da pobreza piauiense ................................................... 146

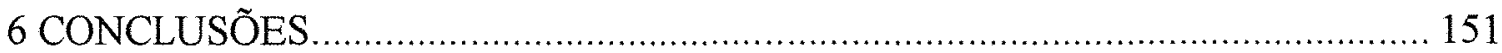

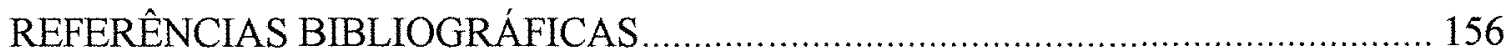

APÊNDICES 


\section{LISTA DE FIGURAS}

1 Média e mediana para população economicamente ativa, excluindo os sem

Página rendimento; Piauí - 1960, 1970 e 1980

2 Índice de Gini, índice de Sen e índice de FGT para população economicamente ativa com rendimento; Piauí- 1960, 1970 e 1980 56

3 Renda média e mediana (em SM) para pessoas economicamente ativas com rendimento; Piauí - 1984 a 1990, 1992, 1993, 1995 e 1996

4 Evolução do produto interno bruto per capita (US\$ constantes em 1995);

Brasil, Nordeste e Piauí- 1985 a 1995 78

5 Renda média (em SM) para pessoas economicamente ativas com rendimento; Brasil, Nordeste e Piauí; 1984 a 1990, 1992, 1993, 1995 e 1996 78

6 Índice de Gini para pessoas economicamente ativas com rendimento; Brasil, Nordeste e Piauí - 1984 a 1990, 1992, 1993, 1995 e 1996.

7 Índice de Sen para pessoas economicamente ativas com rendimento; Brasil, Nordeste e Piauí - 1984 a 1990, 1992, 1993, 1995 e 1996

8 Proporção de domicílios particulares permanentes, segundo algumas características do domicílio urbano; Piauí- 1984 a 1996

9 Proporção de domicílios particulares permanentes, segundo algumas características do domicílio rural. Piauí- 1984 a 1996.

10 Proporção de domicílios particulares permanentes, segundo alguns bens duráveis existentes no domicílio urbano; Piauí -1984 a 1996 
11 Proporção de domicílios particulares permanentes, segundo alguns bens duráveis existentes no domicílio rural; Piauí -1984 a 1996 86

12 Histograma da renda para PEA com rendimento e domicílio urbano; Piauí -1992 ..97

13 Histograma da renda para PEA com rendimento e domicílio urbano; Piauí -1995 .. 97

14. Histograma da renda para PEA com rendimento e domicílio rural; Piauí -1992 _... 98

15 Histograma da renda para PEA com rendimento e domicílio rural; Piauí -1995 ...... 98

16 Proporção das pessoas economicamente ativas com rendimento, segundo o sexo; Piauí - 1992, 1993 e 1995

17 Pessoas ocupadas em atividade não-agrícola por formas de inserção; Piauí -1992 108

18 Pessoas ocupadas em atividade não-agrícola por formas de inserção; Piauí - 1995 108

19 Pessoas ocupadas em atividade agrícola por formas de inserção; Piauí -1992 ....... 109

20 Pessoas ocupadas em atividade agrícola por formas de inserção; Piauí -1995 ,...... 109

21 Histograma da renda para pessoas ocupadas na atividade agrícola; Piauí $-1992 \ldots 112$

22 Histograma da renda para pessoas ocupadas na atividade não-agrícola; Piaui-1992

23 Histograma da renda para pessoas ocupadas na atividade agrícola; Piauí - $1995 \ldots 113$

24 Histograma da renda para pessoas ocupadas na atividade não-agrícola; Piauí -1995

25 Curva de Lorenz para as pessoas economicamente ativas; Piauí -1992, 1993 e 1995

26 Curva de Lorenz para as pessoas economicamente ativas, situação do domicílio urbano; Piauí-1992, 1993 e 1995.

27 Curva de Lorenz para as pessoas economicamente ativas, situação do domicílio rural; Piauí - 1992, 1993 e 1995 
28 Rendimentos médio e mediano para pessoas economicamente ativas com rendimento, segundo situação do domicílio urbano ou rural; Piauí - 1992, 1993 e 1995

29 Proporção da renda apropriada pelos $50 \%$ mais pobres, pelos $10 \%$ mais ricos e pelos $5 \%$ mais ricos entre as pessoas economicamente ativas com rendimento, conforme domicílio urbano ou rural; Piaú - 1992, 1993 e 1995

30 Proporção de pobres $(H)$ entre as pessoas economicamente ativas com rendimento; Piauí- 1992, 1993 e 1995

31 Proporção de pobres $(H)$ entre as pessoas economicamente ativas, conforme a situação do domicílio; Piauí; 1992, 1993 e 1995.

32 Contribuição das pessoas economicamente ativas com domicílio urbano e rural no total da pobreza (em percentual); Piaú-1992,1993 e 1995 


\section{LISTA DE QUADROS}

Página

1 Composição do IDS 12 


\section{LISTA DE TABELAS}

Página

1 Indicadores de saúde, educação e renda e o índice de desenvolvimento social para Brasil, Nordeste e Piauí em 1980/1984 e 1991

2 Índice de desenvolvimento humano (IDH) para Brasil, Nordeste e Piauí-1991 16

3 Medidas de tendência central, desigualdade e pobreza para população economicamente ativa, incluindo os sem rendimento; Piauí - 1960, 1970 e1980

4 Medidas de tendência central, desigualdade e pobreza para população economicamente ativa, excluindo os sem rendimento; Piauí - 1960, 1970 e $1980 \ldots . .54$

5 Evolução da população residente e taxa média geométrica de crescimento anual; Piauí-1960, 1970 e 1991

6 População economicamente ativa (PEA) do Piaui, conforme os setores produtivos; 1960/1980 58

7 Variação percentual do PIB do Brasil, Região Nordeste e Estados nos quinqüênios 1960-65, 1965-70, 1970-75 e 1975-80

8 Medidas de desigualdade e pobreza para as pessoas economicamente ativas, incluindo os sem rendimento, por setores; Piauí - 1980

9 Medidas de desigualdade e pobreza para as pessoas economicamente ativas com rendimento, por setores; Piauí - 1980 .

10 Decomposição da medida de pobreza (Índice de FGT) por setores; Piauí -1980 _..... 64

11 Decomposição da medida de pobreza (Índice de FGT) por sexo; Piauí -1980 64 
12 Coeficientes da equação de rendimento ajustada, valores $t$ e números-índices; Piauí- 1980 .

13 Coeficientes das equações de rendimento ajustadas para cada setor; Piauí $-1980 \ldots 69$

14 Número de observações, valores de $\mathrm{F}$ e $\mathrm{R}^{2}$ e contribuição marginal de cada fator para os modelos estimados para cada setor; Piauí- 1980

15 Números-índices do nível do rendimento estimado para as categorias dos fatores considerados no modelo de regressão; Piauí- 1980

16 Medidas de tendência central e desigualdade para a população economicamente ativa com rendimento; Piaui - 1984 a 1990, 1992, 1993, 1995 e 1996.

17 Variação percentual do PIB do Brasil, da Região Nordeste e dos Estados nos quinqüênios; 1980-85, 1985-90 e 1990-95

18 Crescimento percentual do rendimento médio; Brasil, Nordeste e Piauí nos períodos de 1992 a 1996, 1995 a 1996 e 1993 a 1995

19 Medidas de pobreza para a população economicamente ativa com rendimento; Piauí - 1984 a 1996 80

20 Indicadores demográficos e econômicos; Piauí- 1992, 1993 e 1995 93

21 Freqüência, freqüência relativa e densidade de freqüência relativa das pessoas economicamente ativas com rendimento por classes de rendimento, segundo situação do domicílio; Piauí - 1992

22 Freqüência, freqüência relativa e densidade de freqüência relativa das pessoas economicamente ativas com rendimento por classes de rendimento, segundo situação do domicílio; Piauí - 1993

23 Freqüência, freqüência relativa e densidade de freqüência relativa das pessoas economicamente ativas com rendimento por classes de rendimento, segundo situação do domicílio; Piauí - 1995

24 Distribuição percentual da população economicamente ativa com rendimento por classes de rendimento, segundo sexo; Piauí - 1992 
25 Distribuição percentual da população economicamente ativa com rendimento por classes de rendimento, segundo sexo; Piauí - 1993.

26 Distribuição percentual da população economicamente ativa com rendimento por classes de rendimento, segundo sexo; Piauí - 1995

27 Distribuição percentual das pessoas economicamente ativas com rendimento por classes de rendimento, segundo idade; Piauí - 1992.

28 Distribuição percentual das pessoas economicamente ativas com rendimento por classes de rendimento, segundo idade; Piauí - 1993.

29 Distribuição percentual das pessoas economicamente ativas com rendimento por classes de rendimento, segundo idade; Piauí - 1995.

30 Distribuição percentual da população economicamente ativa com rendimento por classes de rendimento, segundo anos de estudo (escolaridade); Piauí - 1992

31 Distribuição percentual da população economicamente ativa com rendimento por classes de rendimento, segundo anos de estudo (escolaridade); Piauí - 1993.

32 Distribuição percentual da população economicamente ativa com rendimento por classes de rendimento, segundo anos de estudo (escolaridade); Piauí - 1995

33 Pessoas ocupadas no mercado de trabalho por forma de inserção;

Piauí - 1992, 1993 e 1995

34 Distribuição percentual das pessoas ocupadas por classes de rendimento, segundo setor de atividade do trabalho principal; Piaui -1992

35 Distribuição percentual das pessoas ocupadas por classes de rendimento, segundo setor de atividade do trabalho principal; Piauí -1993

36 Distribuição percentual das pessoas ocupadas por classes de rendimento, segundo setor de atividade do trabalho principal; Piauí - 1995

37 Distribuição do rendimento da população economicamente ativa (em percentis) e rendimento médio do estrato; Piauí - 1992, 1993 e 1995

38 Medidas de desigualdade da distribuição da renda entre as pessoas economicamente ativas com rendimento; Piauí - 1992, 1993 e 1995 118 
39 Medidas de desigualdade da distribuição da renda entre as pessoas economicamente ativas com rendimento e domicílio urbano; Piauí - 1992,1993 e 1995 120

40 Medidas de desigualdade da distribuição da renda entre as pessoas economicamente ativas com rendimento e domicílio rural; Piauí- 1992, 1993 e 1995

41 Coeficientes da equação de regressão ajustada; Piauí- 1992, 1993 e 1995

42 Número de observações, valores de $\mathrm{F}$ e $\mathrm{R}^{2}$ e contribuição marginal de cada fator para o modelo estimado; Piauí- 1992, 1993 e 1995.

43 Número de observações, valores de $\mathrm{F}$ e $\mathrm{R}^{2}$ e a contribuição marginal de cada fator para o modelo estimado, por situação do domicílio; Piauí-1992, 1993 e 1995

44 Número de observações, valores de $\mathrm{F}$ e $\mathrm{R}^{2}$ e a contribuição marginal de cada fator para o modelo estimado, conforme atividade principal agrícola;

Piauí- 1992, 1993 e 1995

45 Números-índices do nível do rendimento estimado para as categorias dos fatores considerados no modelo de regressão; Piauí- 1992, 1993 e 1995

46 Números-índices do nível do rendimento estimado para as categorias dos fatores considerados no modelo de regressão, conforme situação do domicílio urbano; Piauí- 1992, 1993 e 1995

47 Números-índices do nível do rendimento estimado para as categorias dos fatores considerados no modelo de regressão, conforme situação do domicílio rural; Piauí- 1992, 1993 e 1995

48 Números-índices do nível do rendimento estimado para as categorias dos fatores considerados no modelo de regressão, conforme atividade principal agrícola; Piauí- 1992, 1993 e 1995 136

49 Medidas de pobreza absoluta entre as pessoas economicamente ativas com rendimento; Piauí -1992, 1993 e 1995

50 Pobreza absoluta entre as pessoas economicamente ativas com rendimento no domicílio urbano; Piauí -1992, 1993 e 1995 
51 Pobreza absoluta entre as pessoas economicamente ativas com rendimento no domicílio rural; Piauí -1992, 1993 e 1995

52 Pobreza absoluta entre as pessoas economicamente ativas com rendimento na atividade agrícola; Piauí -1992, 1993 e 1995

53 Decomposição da pobreza, considerando as pessoas economicamente ativas com rendimento, por situação do domicílio; Piauí - 1992, 1993 e 1995

54 Decomposição da pobreza, considerando as pessoas economicamente ativas com rendimento e ocupadas em atividade agrícola, por faixa etária; Piauí- 1995

55 Decomposição da pobreza, considerando as pessoas economicamente ativas com rendimento e ocupadas em atividade agrícola, por nível de escolaridade; Piauí- 1995

56 Decomposição da pobreza, considerando as pessoas economicamente ativas com rendimento e ocupadas em atividade agrícola, por sexo; Piauí- 1995

57 Decomposição da pobreza, considerando as pessoas economicamente ativas com rendimento e ocupadas em atividade agrícola, por formas de inserção no mercado de trabalho; Piauí- 1995 


\title{
RENDA: DESIGUALDADE E POBREZA NO ESTADO DO PIAUÍ
}

\author{
Autora: JAÍRA MARIA ALCOBAÇA GOMES \\ Orientador: Prof. RODOLFO HOFFMANN
}

\section{RESUMO}

O Estado do Piauí é classificado pelo IPEA (1996) como um estado de baixo nível de desenvolvimento humano, apresentando o pior indicador de renda entre as Unidades da Federação.

Analisa-se a distribuição da renda no Piauí, identificam-se os condicionantes sócio-demográficos e conjunturais dessa distribuição e verifica-se a influência das variáveis situação do domicílio urbano e rural, educação, sexo, idade, posição na ocupação, horas de trabalho e setor de atividade no perfil distributivo da renda e na pobreza entre as pessoas economicamente ativas.

A pobreza é enfocada sob o ponto de vista da insuficiência de renda, associandose também outras variáveis relativas à caracterização dos domicílios, segundo infraestrutura básica e alguns bens duráveis. 
Os dados censitários de 1960, 1970 e 1980 mostraram que o crescimento econômico determinou a elevação da renda média, da desigualdade e a redução da pobreza no Piauí, semelhante ao ocorrido no Nordeste e Brasil. As características sóciodemográficas e produtivas do Piauí determinaram que o crescimento da renda média fosse superior ao da nordestina e brasileira nesses anos, mas a desigualdade da distribuição da renda cresce a taxas maiores, reduzindo os efeitos positivos do aumento da renda média sobre a diminuição da pobreza.

As informações individuais da Amostra de 0,8\% do Censo Demográfico de 1980 indicaram que a desigualdade da distribuição da renda entre as pessoas economicamente ativas está associada ao sexo (32,3\%), à idade (31,9\%) e à posição na ocupação $(14,2 \%)$ no setor agrícola. No setor industrial, à idade $(37,7 \%)$ e ao sexo $(28,0 \%)$ e, nos serviços, à escolaridade $(29,2 \%)$, à idade $(26,2 \%)$ e ao sexo $(25,9 \%)$. Essas contribuições para as variações do rendimento refletem a composição do mercado de trabalho estadual.

Os resultados das regressões, considerando os dados publicados nas PNAD de 1984 a 1996, indicaram que o nível de pobreza absoluta no Piauí está mais associado com as variações na renda média do que com as mudanças no grau da desigualdade da distribuição da renda.

As equações de regressões ajustadas mostraram que a influência da inflação sobre a desigualdade e a pobreza é positiva, entretanto, verificou-se que o coeficiente dessa variável não é estatisticamente diferente de zero.

A análise dos dados individuais das PNAD de 1992, 1993 e 1995 mostrou que os principais determinantes da renda de uma pessoa economicamente ativa no Piauí são a idade e a escolaridade. No domicílio urbano destacam-se a idade e a escolaridade e, no rural, a idade, horas de trabalho e a escolaridade. $\mathrm{Na}$ atividade agrícola, a idade, a posição na ocupação e horas de trabalho. 
A pobreza nos anos 90 é ainda elevada, com uma proporção de pobres de $50,8 \%$ (1995) das pessoas economicamente ativas com domicilio urbano. Essa proporção se eleva para $78,3 \%$, quando se considera o domicílio rural e para $80,1 \%$ quando as pessoas são ocupadas na agricultura.

O desenho de políticas sociais deve, então, passar prioritariamente pelo incentivo à educação e alternativas de renda agrícola, mas contemplando formas de renda oriundas de atividades não-agrícolas. 


\title{
INCOME: INEQUALITY AND POVERTY IN THE STATE OF PIAUÍ
}

\author{
Author: JAÍRA MARIA ALCOBAÇA GOMES \\ Adviser: Prof. RODOLFO HOFFMANN
}

\section{SUMMARY}

The State of Piaui is classified by the IPEA (1966) as a state of low level of human development, showing the worst indicator of income among the Unities of the Federation.

This work analyzes the income distribution in Piaui, it identifies the socialdemographic conditioning and combined factors of this distribution and it verifies the influence of variable situations of urban and rural domicile, education, sex, age, position in occupation, work hours and the activity sector in the distributive profile of income and in poverty among persons economically active.

Poverty is focused under the point of view of income insufficiency, being also associated to other variables related to the characterization of domiciles according to the basic infra-structure and to some durable assets. 
The census data of 1990,1970 and 1980 show that the economic growth has determined the elevation of the average income, of inequality and the reduction of poverty in Piaui, similar to what has occurred to the Northeast region and to Brazil. The social-demographic and productive characteristics of Piaui have determined that the growth of average income has been superior to the Northeast and to the Brazilian incomes during these years, but the inequality of income distribution grows under highest rates, reducing the positive effects of the increase of the average income over the diminution of poverty.

The individual informations of the Sample of $0,8 \%$ of the Demographic Census of 1980 , indicated that the inequality of income distribution among the persons economically active is associated to sex $(32,3 \%)$, to age $(31,9 \%)$, and to the position in the occupation $(14,2 \%)$ in the agricultural sector. In the industrial sector it is associated to age $(37,7 \%)$, to sex $(28.0 \%)$ and, to services, to school level $(29,2 \%)$ and to sex $(25,9 \%)$. These contributions to the variations of income reflect the composition of the state work market.

The results of regressions, considering the data published in the PNAD from 1984 to 1996, indicated that the level of absolute poverty in Piaui is more associated with the variations of the average income than with the changes in the degree of inequality of income distribution.

The equations of adjusted regressions showed that the influence of inflation over the inequality and poverty is positive, however it was verified that the coefficient of this variable is not statistically different from zero.

The analysis of individual data of the PNAD of 1992, 1993 and 1995 showed that the principal determinants of income of a person economically active in Piaui are age and school level. In the urban domicile, age and school level are emphasized; and in the 
rural domicile, age, work hours and school level are emphasized. In the agricultural activity, age, position in the occupation and work hours are emphasized.

Poverty in the 90 's is still elevated, with a proportion of poor people of $50,8 \%$ (1995) of people economically active with urban domicile. This proportion is elevated to $78,3 \%$ when the rural domicile is considered and for $80,1 \%$ when people are occupied in the agriculture.

The design of social politics must then pass with priority by the incentive to education and to alternatives of agricultural income but regarding forms of income derived from non agricultural activities. 


\section{INTRODUÇÃO}

Sem refutar outros indicadores relevantes na caracterização do grau de desenvolvimento humano de uma sociedade, tais como longevidade, saúde e nível educacional, destaca-se a importância do estudo da distribuição da renda, haja vista que $\sigma$ indicador de renda, em qualquer circunstância, temporal e/ou espacial, é elemento decisivo para a análise do processo de desenvolvimento das nações, regiões, estados e municípios. Aliás, segundo Cacciamali (1992, p.420),

"A análise da evolução da distribuição da renda é vital para diagnosticar os beneficiários do processo de crescimento econômico e para orientar grupos e partidos políticos nas demandas sociais que conduzam a sociedade a um nivel de consumo material mais igualitário e justo - de acordo com os valores sociais determinados."

Essa idéia já vem sendo colocada desde a década de 1970, com Fishlow ( 1973), quando afirma que é através de diagnósticos abrangentes das características dos pobres que se podem formular e implementar políticas eficientes que produzam efeitos permanentes.

A carência da literatura sobre a distribuição da renda e pobreza no Estado do Piauí é grande, na medida em que o estado é apenas citado nos estudos para o Brasil e 
região Nordeste, pelo seu alto grau de desigualdade na distribuição da renda e pobreza. Portanto, partir do princípio de que os estudos, em particular aqueles sobre a distribuição da renda na região Nordeste, explicam o caso do Piauí, é negar as especificidades inerentes aos estados.

Nas palavras de Cavalcanti (1978, p.283),

"Qual o sentido de se destacar o Estado do Piauí numa apreciação do panorama de pobreza encontrado no Nordeste do Brasil, uma região pobre por si própria, conforme amplamente sabido? Na realidade, justamente por se sobressair como área de concentração de baixos padrões de vida na macrorregião brasileira mais atrasada, merece o Piaui tratamento especial. O estado, além disso, possui algumas características econômicas e demográficas que o singularizam no cenário nacional. Seu território, com efeito, está na transição entre o espaço semi-árido do sertão nordestino e o ecúmeno úmido da região amazônica, o parentesco embora sendo nitidamente maior com o primeiro. É um território de população pouco adensada, com níveis de vida miseráveis, mas onde se realiza um esforço árduo, até resvalando para padrões épicos, no sentido de se conseguir assegurar o sustento das pessoas. $O$ conjunto de fatores que delineiam as peculiaridades econômicas piauienses constrói assim um cenário de desafio de tal ordem que qualquer iniciativa tendente a modificar o quadro de coisas observado deve ser projetado sobre a tela de dificuldades e de traços específicos da realidade do Piauí. Sem esse confronto, uma apreciação do valor das iniciativas perde força e solidez."

A disponibilidade e o acesso às informações sobre a distribuição da renda e pobreza no Piauí constituem requisitos essenciais para um processo de desenvolvimento com equidade, na medida que as atividades de coleta, sistematização, análise e divulgação dos dados sócio-econômicos assumem caráter fundamental para uma ação ordenada global e maior aprofundamento das políticas de redução da pobreza. 
Segundo o IPEA (1996), o Piauí é classificado como um estado de baixo nível de desenvolvimento humano, apresentando o pior indicador de renda entre as Unidades da Federação. Assim, a explicação do baixo nível de desenvolvimento humano está em grande parte na estrutura da distribuição da renda e pobreza.

Objetiva-se, pois, analisar a distribuição da renda no Estado do Piauí (PI), no período de 1980-96. Especificamente, pretende-se conhecer como se distribui a renda no Piauí, identificar os condicionantes sócio-demográficos e econômicos, e os conjunturais dessa distribuição, bem como calcular e analisar a influência desses condicionantes nas variações dos rendimentos das pessoas economicamente ativas.

A pobreza, nessa pesquisa, será enfocada sob o ponto de vista da insuficiência de renda, embora seja válido o argumento de que a utilização da renda como indicador único da pobreza é insuficiente. Faz-se, portanto, necessário associar à caracterização da pobreza outras variáveis relativas à satisfação ou insatisfação de necessidades básicas (infra-estrutura social e acesso a bens de consumo duráveis).

A pesquisa apresenta quatro conjuntos de informações. No primeiro, mostra-se o comportamento das medidas de desigualdade e pobreza nas décadas de $1960,1970 \mathrm{e}$ 1980, com base nos dados dos Censos Demográficos. Esse período se caracteriza pelo forte crescimento da economia brasileira.

No segundo, analisa-se a situação em 1980, utilizando os dados individuais da Amostra de 0,8\% do Censo Demográfico de 1980, verificando-se os fatores que mais contribuíram para desigualdade e pobreza.

No terceiro, examina-se a evolução da desigualdade e pobreza no período de 1984 a 1996, a partir das informações publicadas nas Pesquisas Nacionais por Amostra de Domicílios - PNAD, observando-se como a crise e estagnação da economia nacional 
afeta a economia piauiense e sua distribuição da renda. A seguir, o quadro dos anos 90 é focalizado através dos microdados das PNAD de 1992, 1993 e 1995, enfatizando-se as modificações ocorridas na estrutura da distribuição da renda com a implementação do Plano Real e seus reflexos na pobreza do Piauí.

A metodologia consiste em analisar a relação entre desenvolvimento e distribuição da renda, através dos índices de desenvolvimento social e humano para Brasil e região Nordeste, contextualizando o Estado do Piauí. A análise empírica usa como instrumental as medidas de desigualdade e pobreza para mostrar a estrutura da distribuição da renda e pobreza, nas décadas de 1980 e 1990, e a análise de regressão e decomposição do índice de Foster, Greer e Thorbecke (FGT) para verificar a influência das variáveis sócio-demográficas e econômicas no rendimento das pessoas economicamente ativas.

Esse estudo compõe-se de um capítulo inicial em que se discute a relação entre desenvolvimento e distribuição da renda e revisa-se o debate das causas da desigualdade da distribuição da renda no Brasil, nas décadas de 1970 e 1980. No segundo capítulo indicam-se os procedimentos metodológicos, e, no terceiro, mostra-se a distribuição da renda e pobreza no Piauí nas décadas de 1960, 1970 e 1980. No quarto capítulo analisase a evolução da distribuição da renda de 1984 a 1996, identifica-se a estrutura da distribuição da renda nos anos 90 , distinguindo-se pessoas com domicilio urbano ou rural e destacando a atividade agrícola, e examinam-se os fatores explicativos desse perfil e da pobreza. 


\section{RENDA E DESENVOLVIMENTO HUMANO}

O conceito de desenvolvimento humano tem sua divulgação pelo Programa das Nações Unidas para o Desenvolvimento (PNUD), no início da década de 90, e está associado ao ciclo de conferências sociais da Organização das Nações Unidas (ONU).

A concepção de desenvolvimento humano se apresenta como uma alternativa à visão mais tradicional e estritamente econômica do processo de desenvolvimento. Nessa concepção estão presentes três princípios básicos: desfrutar uma vida longa e saudável, adquirir conhecimento e ter acesso aos recursos necessários a um padrão de vida decente.

Essa noção de desenvolvimento é ampla e, por isso, exige a incorporação de múltiplas dimensões, entre elas as econômica, social, política, cultural e ambiental. A amplitude desse conceito não significa uma contraposição ao conceito estritamente econômico que se identifica com crescimento, porque, a longo prazo, nenhum país pode manter ou aumentar o bem-estar de sua população se não experimentar um processo de crescimento que implique aumento da produção e da produtividade do sistema econômico, ampliação das opções oferecidas a seus habitantes e oportunidades de empregos produtivos e adequadamente remunerados. 
Do ponto de vista do desenvolvimento humano o relevante não é apenas a magnitude de expansão da atividade produtiva, mas sua natureza e qualidade, incluindo a forma pela qual os frutos do crescimento econômico são partilhados. Nesse contexto, o desenvolvimento humano pressupõe a identificação e implementação de trajetórias de crescimento econômico que viabilizem um desenvolvimento sustentável.

Os novos condicionantes do processo de desenvolvimento humano no Brasil são um novo padrão demográfico, caracterizado pela queda acentuada da taxa de fecundidade e o declínio, rápido, da proporção de jovens, enquanto a proporção de idosos cresce ainda muito lentamente; as exigências do crescimento econômico e da formação de uma economia global que exige uma política de estabilização para controle da inflação, difusão de um novo paradigma tecnológico e organizacional, competitividade comercial do país no contexto do processo de globalização e da constituição do Mercosul; e a definição dos níveis de utilização dos recursos naturais que não impliquem em degradação e exaustão, para qualquer tentativa de delinear e perseguir trajetórias de sustentabilidade.

O reconhecimento desses condicionantes demográficos, econômicos e ambientais é fundamental para que se possa consolidar uma trajetória estável de expansão no Brasil, com melhor distribuição interpessoal e interregional dos frutos do crescimento e redução da pobreza.

\section{1 Índices de desenvolvimento}

Nessa seção, conceituam-se os índices de desenvolvimento humano, social e de bem-estar rural que foram utilizados para mensurar o grau de desenvolvimento do Brasil, de suas Macrorregiões e Estados. 


\subsection{1 Índice de desenvolvimento humano (IDH)}

O processo de desenvolvimento humano, por sua natureza de múltiplas dimensões, é de difícil mensuração. É necessário, portanto, um conjunto de indicadores estatísticos que focalizem as diversas facetas desse processo. Essas estatísticas têm sido divulgadas sistematicamente nos Relatórios de Desenvolvimento Humano e desde seu início, em 1990, vem sendo estudada a construção de um indicador com o objetivo de aperfeiçoar o sistema de estatísticas sociais dos países e desalojar a medida de renda (PIB per capita) da condição de única medida síntese do processo de desenvolvimento.

O índice de desenvolvimento humano (IDH) proposto pelo PNUD é um indicador que tenta captar e sintetizar as diversas e complexas dimensões do processo de desenvolvimento humano. Esse índice vem sendo calculado para grande número de países dentro das três opções básicas do desenvolvimento humano: desfrutar uma vida longa e saudável, adquirir conhecimento e ter acesso aos recursos necessários para um padrão de vida decente.

Essas opções são incorporadas ao IDH através das variáveis que medem a longevidade, o nível educacional e a renda. As variáveis que compõem esse índice sofrem alterações desde 1990 e as estabelecidas no Relatório de Desenvolvimento Humano do Brasil em 1996 seguem a metodologia do Relatório de Desenvolvimento Humano da ONU de 1995.

As variáveis são a esperança de vida ao nascer para indicador de longevidade; a taxa de alfabetização dos adultos e a taxa combinada de matrícula nos ensinos fundamental, médio e superior, reunidas num indicador único através de média ponderada, com pesos dois e um, respectivamente, para o indicador do nível educacional e a renda per capita para o indicador do acesso a recursos (padrão de vida). 
Um dos problemas metodológicos ${ }^{1}$ que se apresenta no $\mathbf{I D H}$ é combinar indicadores medidos em diferentes unidades. Então, para encontrar uma medida comum, o IDH considera um mínimo e um máximo para cada dimensão e mostra onde cada país ou estado está em relação a estes valores extremos.

A primeira etapa de construção do $\mathbf{D H}$ é definir a medida da privação de uma dada região em relação a cada uma das quatro variáveis consideradas. A medida é obtida situando-se o valor efetivamente observado para a variável na região em uma escala de 0 a 1 , limites que correspondem ao valor mínimo e máximo que pode ser atribuído à variável.

Os limites mínimo e máximo estabelecidos foram os seguintes: para esperança de vida ao nascer, 25 e 85 anos; para a taxa de alfabetização dos adultos, $0 \%$ e 100\%; para a taxa combinada de matrícula nos ensinos fundamental, médio e superior, $0 \% \mathrm{e}$ $100 \%$; e para renda real per capita, US\$ 100 e US\$ 40.000. Com esses limites, o valor de cada um dos indicadores que compõem o IDH é definido para cada região pela expressão

Indicador $=($ valor observado - valor mínimo $) /($ valor máximo - valor mínimo $)$

O indicador de longevidade $\left(L_{i}\right)$ é dado pela simples aplicação dessa expressão ao valor observado da esperança de vida ao nascer $\left(I_{i}\right)$ :

$L_{i}=\left(I_{i}-25\right) /(85-25)$

O indicador de nível educacional $\left(E_{i}\right)$ é dado pela aplicação na equação (1) dos valores observados para as variáveis relacionadas à educação (a taxa de alfabetização dos adultos $a_{i}$ e a taxa combinada de matrícula nos ensinos fundamental, médio e

\footnotetext{
${ }^{1}$ Vide quais os dados utilizados para o cálculo do IDH em IPEA (1996, p. 152)
} 
superior $m_{i}$ ), calculando-se a média ponderada das duas variáveis na qual a primeira tem peso dois e a segunda peso 1 , ou seja,

$E_{i}=2 / 3\left\{\left(a_{i}-0\right) /(100-0)\right\}+1 / 3\left\{\left(m_{i}-0\right) /(100-0)\right\}$

O procedimento do cálculo do indicador renda ${ }^{2}$ é mais complicado e admite a hipótese de que a contribuição da renda para o desenvolvimento humano apresenta rendimentos decrescentes. Esta hipótese é incorporada ao IDH pela fórmula de Atkinson relativa à utilidade da renda, em que

$W(y)=[1 /(1-e)] y^{1-e} \quad$ para $0<e \neq 1$

e

$W(y)=\ln y$ para $e^{=1}$

em que $W(y)$ é a utilidade ou bem-estar derivado da renda $y$. Verifica-se que $d W / d y=y^{-e}$, mostrando que a elasticidade da utilidade marginal em relação à renda é $-e$.

Segundo IPEA (1996), o valor assumido pela elasticidade é relacionado à renda $y^{*}$. Este parâmetro $y^{*}$ indica o nível de renda a partir do qual esta variável passa a apresentar rendimentos decrescentes, e foi definido como equivalente à renda média mundial e fixado em US $\$ 5.120(\mathrm{PPC})^{3}$, valor da renda média mundial em 1992. Podese verificar que, o limite superior para o bem-estar $W$, isto é, o valor descontado do limite de US $\$ 40.000$, estabelecido anteriormente, é $W=5449$.

O indicador renda $\left(R_{i}\right)$ é determinado pela expressão

\footnotetext{
${ }^{2}$ Para esclarecimentos sobre o cálculo do índice de renda, consultar nota técnica em IPEA (1996, p.151 152).

${ }^{3}$ Considera-se o PIB per capita ajustado ao custo de vida local, isto é, em unidades com paridade de poder de compra (PPC).
} 
$R_{i}=\left(W_{i}-100\right) /(5449-100)$

onde $W_{i}$ é a utilidade ou bem-estar derivado da renda $y_{i}$.

A etapa final consiste em agregar os indicadores de longevidade, educação e renda em um indicador único, através da média simples dos valores obtidos para as três dimensões.

$I_{i}=\left(L_{i}+E_{i}+R_{i}\right) / 3$

Esses índices, calculados para regiões geográficas e estados revelam um perfil mais pormenorizado da privação de cada região ou estado. Por isso é uma ferramenta indispensável para o planejamento do desenvolvimento e sua avaliação. O IDH apresenta-se como alternativa ao PIB para medir o progresso sócio-econômico relativo, em nível nacional e internacional, habilitando as pessoas e os seus governantes a avaliar permanentemente o progresso e a definir políticas de intervenção. $\mathrm{O} I \mathrm{DH}$ permite comparar as experiências em diferentes países, estados e municípios.

\subsection{2 Índice de desenvolvimento social (IDS)}

Rodrigues (1994a) propõe o Índice de Desenvolvimento Social (IDS) com o objetivo de medir o desenvolvimento social e detectar até que ponto o crescimento econômico vem beneficiando a população brasileira. 
O IDS fundamenta-se no Índice de Desenvolvimento Humano (IDH), das Nações Unidas ${ }^{4}$, e visa ao ordenamento dos países ou estados pesquisados segundo os valores obtidos para os indicadores selecionados.

A autora tenta diferenciar os dois índices acima, incorporando a idéia de que, para os países em desenvolvimento, urge introduzir um conceito intermediário de desenvolvimento que extrapole a noção de crescimento econômico e que também não pretenda avaliar somente o grau de realização pessoal dos indivíduos.

"Esse conceito pode ser denominado desenvolvimento social
e passa a ser definido como grau de justiça social, ou seja,
a forma pela qual os resultados do desenvolvimento
econômico revertem em beneficio para a sociedade como um
todo ou para frações dela. O desenvolvimento social pode ser
entendido, então, como pré-requisito para o desenvolvimento
humano, este último mais adaptado à análise da realidade
dos países desenvolvidos." (Rodrigues, 1994a, p.7).

Para o caso do Brasil, a autora considera fundamental incorporar uma medida de desigualdade da distribuição da renda na composição do índice de renda. Os indicadores mais utilizados, em nível internacional, são o coeficiente de Gini e a razão da participação na renda de diferentes estratos da população. A autora apresenta três versões para o $\operatorname{IDS}^{5}$, e, na última, de fevereiro de 1994, o índice de renda incorpora um indicador de renda média e um outro de distribuição da renda, sendo composto pelos indicadores que constam no quadro 1.

\footnotetext{
${ }^{4}$ Rodrigues (1994a) comenta as criticas de Osvaldo Sunkel e Gustavo Zuleta, ambos da Comissão Econômica para América Latina (CEPAL), sobre o $\mathrm{IDH}$, quanto à utilização da esperança de vida e taxa de alfabetização de adultos nos indicadores de saúde e educação, vez que não retratam as disparidades regionais e distorcem os niveis de qualidade de vida alcançados. A autora acata a crítica, mas, paradoxalmente, usa os mesmos indicadores para compor o IDS, justificando sua opção por eles representarem uma primeira aproximação em termos de mensuração do indice. No que se refere à relatividade do índice, supor que o indicador de um pais está explicitamente ligado ao de outro, em particular quando esse pais apresenta o valor máximo ou minimo de desenvolvimento social, pode ser contestada, mas a definição do intervalo de variação para os indicadores que compõem o IDS pretende delimitar apenas o contexto espacial ou temporal dentro do qual se pretende analisar determinada realidade social. Esse procedimento metodológico não implica, de forma alguma, atribuir qualquer grau de dependência aos resultados observados para paises distintos. Um último ponto da crítica é quanto ao indice de renda, pois a Organização das Naçðes Unidas (ONU) inclui apenas a renda média, desconsiderando a distribuição.

${ }^{5}$ Consulte Rodrigues (1994a, p.2a.).
} 
Quadro 1. Composição do IDS.

\begin{tabular}{|c|c|c|c|}
\hline VERSÃO/DATA & INDICADOR SAÚDE & INDICADOR EDUCACCÃO & INDICADOR RENDA \\
\hline $3^{a}$ versão (fev. .94) & $\begin{array}{l}\text { - Esperança de vida ao nascer } \\
\text { (anos) (peso } 0,4) \\
\text { Taxa de mortalidade } \\
\text { infantil }(\%)(\text { peso } 0,6)\end{array}$ & $\begin{array}{l}\text { Taxa de analfabetismo de } \\
\text { adultos }(\%) \text { (peso 0,3) } \\
\text { - Escolaridade média (anos) (peso } \\
0,2) \\
\text { - Taxa de escolaridade superior } \\
(\%) \text { (peso } 0,2) \\
\text { - Taxa de escolaridade básica } \\
\text { deficiente }(\%) \text { (peso } 0,3 \text { ) }\end{array}$ & $\begin{array}{l}\text { Renda média da PEA com } \\
\text { rendimento } \\
\text { (em salários mínimos) (peso } 0,4) \\
\text { Razão } 10 \% \text { mais ricos }(10 \%+\text { ) } \\
20 \% \text { mais pobres }(20 \%-) \\
\text { (vezes) (peso } 0,6)\end{array}$ \\
\hline
\end{tabular}

Fonte: Rodrigues (1994a, p.2a).

Nota: Os pesos se referem aos indicadores de referência.

Os indicadores parciais são compostos pela média ponderada das variáveis definidas no citado quadro e o IDS resulta da média aritmética simples de índices parciais, construídos a partir dos indicadores saúde, educação e renda, pois esses três indicadores são igualmente importantes do ponto de vista do bem-estar.

\subsection{3 Índice de bem-estar social para a agricultura (IBES)}

Outro índice para avaliar o bem-estar no Brasil é proposto por Kageyama e Rehder (1993) para o setor agrícola. Esse setor teve o melhor desempenho no período entre 1980 e 1990 , com o produto crescendo $28,2 \%$, contra $3,8 \%$ da indústria. Por outro lado, a renda média e extensão da pobreza tiveram comportamento mais desfavorável no meio rural do que nas cidades.

A complexidade do conceito de bem-estar permite um certo consenso em alguns indicadores como variáveis básicas, tais como moradia, habitação, etc. Quanto à construção de um índice existe controvérsia sobre o do uso de indicadores individuais ou adoção de índice único composto ${ }^{6}$.

\footnotetext{
${ }^{6}$ Vide as argumentações em Kageyama e Redher (1993, p.25-26).
} 
“... a mensuração do bem-estar ainda é matéria que merece muitas pesquisas. Mesmo depois de se obter um indice de nivel de vida ou de bem-estar, ainda existe toda uma discussão acerca da relação entre crescimento econômico e bem-estar, ou da interdependência entre os elementos economicos e sociais." (Kageyama e Rehder, 1993, p.26).

No trabalho desses autores são elaborados dois tipos de índices compostos. Um baseado na metodologia da ONU e procedimentos básicos do IDS de Rodrigues (1994a), denominado IBES (Índice de Bem-Estar Social Rural), em que acrescentaram um número maior de indicadores e diferentes índices parciais?

Essa metodologia não permite comparações adequadas ao longo do tempo, mas apenas entre países (ou regiões) num corte temporal. O outro índice, o IBES-médio, avalia o bem-estar ao longo do tempo. A diferenciação básica está no fato de o índice geral (IBES) efetuar a padronização dos indicadores originais pela conversão em indices simples.

Os índices de desenvolvimento humano (IDH), social (IDS) e bem-estar rural (IBES), calculados nos estudos do IPEA (1996), Rodrigues (1994a) e Kageyama e Redher (1993), respectivamente, são utilizados, na próxima seção, para mostrar o grau de desenvolvimento do Estado do Piauí.

\subsubsection{Os índices de desenvolvimento social e humano para o Estado do Piauí}

O índice de desenvolvimento social (IDS) é a agregação dos resultados dos indicadores saúde, educação e renda, decodificados numa escala entre zero e um.

\footnotetext{
${ }^{7}$ A relação dos indicadores constam no Anexo em Kageyama e Redher (1993, p.39-44),

${ }^{8}$ Vide os procedimentos metodológicos em Kageyama e Redher ( 1993 ).
} 
Quanto mais próximo de um, melhor terá sido a performance dos indicadores sociais de um dado estado em termos da realidade social brasileira dos anos 80 , e vice-versa.

Os resultados de Rodrigues (1994a) apontaram três grupos de estados com padrões de desempenho distintos entre si, que os caracterizam como de elevado, médio e baixo desenvolvimento em saúde, educação e renda, no cenário brasileiro.

A partir das informações contidas na pesquisa da autora supracitada, elabora-se a tabela 1, que apresenta os indicadores de saúde, educação e renda e o IDS para o Brasil, Região Nordeste e Piauí em 1980/1984 e 1990.

Tabela 1. Indicadores de saúde, educação e renda e o índice de desenvolvimento social (IDS) para o Brasil, Nordeste e Piauí em1980/1984 e 1990.

\begin{tabular}{l|c|c|c|c|c}
\hline \multirow{2}{*}{ ÍNDICES } & \multirow{2}{*}{ BRASIL } & \multicolumn{2}{|c|}{ NORDESTE } & \multicolumn{2}{c}{ PIAUÍ } \\
\cline { 5 - 6 } & & Índice & Classificação & Indice & Classificação \\
\hline Saúde & & & & \\
1980 & 0,528 & 0,217 & 4 & 0,335 & 14 \\
1990 & 0,755 & 0,547 & 4 & 0,727 & 12 \\
Educação & & & & & 20 \\
1984 & 0,538 & 0,177 & 4 & 0,031 & 20 \\
1990 & 0,626 & 0,264 & 4 & 0,153 & 20 \\
Renda & & & & & 20 \\
1984 & 0,388 & 0,135 & 4 & 0,037 & $18^{(3)}$ \\
1990 & 0,370 & 0,148 & 4 & 0,000 & $16^{(4)}$ \\
IDS & & & 4 & 0,134 & \\
$1980 / 1984$ & 0,485 & 0,176 & 4 & 0,293 & \\
1990 & 0,584 & 0,320 & 4 & & \\
\hline
\end{tabular}

Fonte: Dados extraidos de Rodrigues (1994a)

(1) Considerando as quatro macrorregiões brasileiras. (2) Considerando vinte Unidades da Federação. (3) Acima dos Estados da Paraíba (19) e Ceará (20). (4) Acima dos Estados do Ceará (17), Maranhão (18), Alagoas (19) e Paraíba (20). 
O Piauí faz parte do grupo de estados de baixo desenvolvimento. O índice de saúde foi o que obteve melhor desempenho, passando de 0,335 em 1980 para 0,7 $7 \overline{\mathrm{em}}$ 1990. Esse índice obteve elevação devido, em parte, ao decréscimo da mortalidade infantil.

Convém alertar que esses dados sobre mortalidade infantil podem estar falseados pela falta de registro de nascimento. Segundo informações divulgadas na Folha de São Paulo, de 17/11/96, há, no Brasil, 50 milhões de pessoas sem registro de nascimento, não tendo, portanto, existência legal. No Piauí, segundo Salomon (1996) apud Simões (1996), a estimativa elaborada por é de que $72,07 \%$ dos piauienses vivem e morrem sem registro de nascimento, percentual superado apenas pelo Maranhão, com 81,96\%. Para o total da população brasileira, esse percentual é de $30,56 \%$.

Quanto ao indicador de educação, o Piauí ocupa o $20^{\circ}$ lugar, o último na classificação geral dos estados brasileiros, com índice de 0,031, em 1984, e 0,153, em 1990.

Pelo critério da renda, o Piaú é classificado no $20^{\circ}$ lugar em 1984 e 1990 , entre os vinte Estados considerados, com os índices de 0,037 e 0,000, respectivamente.

Em resumo, o grupo de baixo desenvolvimento social engloba todos os estados do Nordeste. O Piauí atinge IDS de 0,134 em 1980/84 e 0,293, em 1990, classificando-se em $18^{\circ}$ lugar e $16^{\circ}$ lugar, respectivamente. O IDS cresceu em todos os estados no período de 1984 a 1990. No Piauí esse crescimento decorre basicamente da elevação do índice da saúde.

$O$ índice de desenvolvimento humano (IDH) torna-se o ponto de partida para o exame do estágio atual do desenvolvimento humano no Brasil e dos desníveis regionais. 
O IPEA (1996) calcula o IDH para o país e cada um dos estados. Os resultados dos IDH para os estados apontam três "Brasis", segundo parâmetros definidos pelo PNUD para comparações internacionais: 1. elevado nível de desenvolvimento humano (Rio Grande do Sul, Distrito Federal, São Paulo, Santa Catarina, Rio de Janeiro, Paraná, Mato Grosso do Sul e Espírito Santo); 2. médio nível de desenvolvimento humano (Minas Gerais, Goiás, Mato Grosso, Rondônia, Amapá, Roraima e Amapá); 3. Baixo nível de desenvolvimento humano (Pará, Acre e os Estados da Região Nordeste).

A tabela 2 apresenta o IDH e seus componentes para o Brasil, Nordeste e Piauí, em 1991. Verifica-se que o índice de esperança de vida ao nascer no Piauí $(0,69)$ é maior do que no Nordeste $(0,57)$. O índice de educação do Piauí $(0,61)$ equipara-se ao do Nordeste $(0,62)$, mas está bem abaixo do índice no Brasil $(0,76)$. A maior discrepância encontra-se no índice da renda: 0,23 para o Piauí, 0,46 para o Nordeste e 0,94 para o Brasil.

Tabela 2. Índice de desenvolvimento humano (IDH) para Brasil, Nordeste e Piauí 1991.

\begin{tabular}{c|c|l|c|l|l|l|l|l}
\hline Unidade & $\begin{array}{c}\text { Esperança } \\
\text { de vida } \\
\text { ao nascer } \\
\text { (anos) }\end{array}$ & $\begin{array}{l}\text { Taxa de } \\
\text { alfabetização } \\
\text { de adultos } \\
(\%)^{(1)}\end{array}$ & $\begin{array}{l}\text { Taxa combinada } \\
\text { de matrículas nos } \\
\text { três níveis de } \\
\text { ensino (\%) }\end{array}$ & $\begin{array}{l}\text { PIB } \\
\text { per } \\
\text { capita } \\
\text { US\$ }\end{array}$ & $\begin{array}{l}\text { Índice de } \\
\text { esperança } \\
\text { de vida }\end{array}$ & $\begin{array}{l}\text { Índice de } \\
\text { educação }\end{array}$ & $\begin{array}{l}\text { Índice } \\
\text { do PIB }\end{array}$ & $\begin{array}{l}\text { Índice de } \\
\text { desenvolvimento } \\
\text { humano }\end{array}$ \\
\hline Brasil & 66 & 79,9 & 68 & 2,920 & 0,69 & 0,76 & 0,94 & 0,797 \\
Nordeste & 59 & 62,4 & 60 & 1,426 & 0,57 & 0,62 & 0,46 & 0,548 \\
Piauí & 65 & 58,3 & 65 & 746 & 0,67 & 0,61 & 0,23 & 0,502 \\
\hline
\end{tabular}

Fonte: IPEA (1996, p.169-170).

(1) coluna 2, referente à população com 15 anos ou mais. (2) coluna 3, percentagem da população de 7 a 22 anos.

A Região Nordeste (IDH igual a 0,548) é identificada como de baixo desenvolvimento humano, incluindo os seus nove estados. No Piauí, o IDH é de 0,502, acima, apenas, dos índices dos estados de Alagoas (0,500) e Paraíba $(0,466)$. 
As diferenças nas posições são explicadas pelos desempenhos com relação à esperança de vida ao nascer ou ao nível educacional. Ocorre uma forte correlação positiva entre a posição ocupada pelo estado em relação à renda per capita e ao nível de escolaridade, isto é, os estados com renda per capita mais elevada apresentam também alto nível de escolaridade. E a variável esperança de vida é a que apresenta maior discrepância com as demais na ordenação.

Para Kageyama e Redher (1993), a evolução do bem-estar rural na década de 80 teve um sentido regional divergente, aumentando as disparidades regionais, posto que os maiores progressos ocorreram nos estados de agricultura moderna.

$O$ índice de bem-estar social rural (IBES) coloca o Piauí em $20^{\circ}$ lugar entre os 20 estados analisados por Kageyama e Redher (1993), tanto em 1981 quanto em 1990. O estado apresenta, também, os piores índices parciais em relação ao Brasil e aos nove estados nordestinos, seja na metodologia da ONU, seja na da média aritmética.

O grau do bem-estar rural é influenciado pela produtividade do trabalho e urbanização. Em 1990, essa influência é positiva para as duas variáveis, que explicam $80 \%$ da soma de quadrados, ou seja, da variabilidade do bem-estar rural, segundo resultados obtidos por Kageyama e Redher (1993). Concluem os autores que as diferenças das condições de vida (bem-estar) da população rural no Brasil podem ser explicadas pela produtividade e urbanização, fatores que representam os efeitos do desenvolvimento econômico sobre o bem-estar rural.

Os índices IDH (IPEA, 1996) e IDS (Rodrigues, 1994a) apontam o baixo nível de desenvolvimento humano e social do Piauí. No que diz respeito à renda e educação, o Piauí é o estado com os piores índices do Nordeste. $O$ índice da saúde é o melhor colocado pela baixa mortalidade e esperança de vida ao nascer relativamente 
alta no Nordeste, mas não se pode esquecer do problema da falta de registro, que permite questionar esses dados.

\subsection{Fatores explicativos da distribuição da renda no Brasil}

A temática da distribuição da renda assume papel fundamental no contexto do desenvolvimento tanto no aspecto qualitativo quanto no de medição do grau desse desenvolvimento. O Brasil tem um perfil distributivo da renda extremamente desigual e se posiciona entre os piores do mundo.

Nas diversas correntes teóricas da ciência econômica surgem interpretações que visam explicar as causas da distribuição da renda. Conforme Dobb (1977), as teorias dependem da visão do processo econômico do pesquisador, além de serem historicamente condicionadas, dificultando uma análise com independência e neutralidade. Por isso, explicar a distribuição da renda é algo muito complexo.

É possível agrupar as teorias explicativas da repartição da renda em dois grandes blocos: (a) teorias da distribuição funcional da renda ${ }^{9}$, que partem da concepção da divisão da renda entre classes sociais participantes do processo de produção ou da repartição da renda pela remuneração dos fatores de produção, de acordo com sua contribuição marginal no processo produtivo; e (b) teorias da distribuição pessoal da renda.

\footnotetext{
${ }^{9} \mathrm{Na}$ teoria da distribuição funcional da renda destacam-se as escolas de pensamento econômico chamadas clássica, marxista e neoclássica.
} 
As explicações sobre a distribuição pessoal da renda foram agrupadas em dois conjuntos explicativos por Bonelli e Ramos $(1993)^{10}$ e estão retratadas na ampla literatura acadêmica sobre a desigualdade da distribuição da renda e pobreza no Brasil, a partir da década de 1970.

Então, para entender a discussão das causas da desigualdade da distribuição da renda e da pobreza como insuficiência de renda, nos anos 90, no Brasil, é importante considerar os elementos que marcaram a discussão nas décadas de 70 e 80, considerando o processo de crescimento econômico acelerado que se implementou a partir do chamado "milagre brasileiro", sob a liderança do setor industrial.

\subsubsection{Controvérsia sobre a distribuição da renda na década de 1970}

O debate sobre a distribuição da renda no Brasil torna-se mais agudo com a divulgação do Censo Demográfico de 1970, que revela o aumento da concentração da renda na década de 1960. Destacaram-se os trabalhos de Albert Fishlow (1972), Rodolfo Hoffmann e João Carlos Duarte (1972) e de Carlos Geraldo Langoni (1973a, 1973b).

Langoni (1973a e 1973b) considera que a elevação do coeficiente de Gini, no período de 1960/70, decorre dos efeitos redistribuitivos do processo de crescimento econômico, em que algumas mudanças na estrutura da população economicamente ativa são responsáveis por grande parcela do aumento da desigualdade na distribuição da

\footnotetext{
${ }^{10}$ Bonelli e Ramos (1993) consideram um primeiro conjunto de teorias, em que os agentes econômicos alocam seu tempo à educação, baseando-se em preferências individuais e nos retornos de mercado nos diferentes niveis educacionais.

Um segundo conjunto de teorias. agrupadas em: 1) Segmentação e outras imperfeiçðes de mercado. (a) Teorias dos mercados internos de trabalho e dualismo _ as variáveis explicativas são representadas por itens como educação, condições específicas da região onde opera a firma, custos de rotatividade e poder de barganha dos sindicatos;

(b) Teorias de competição por emprego _ os salários são determinados pelas características dos postos de trabalho, ou seja, a produtividade decorre do montante do capital humano acumulado e dos fatores específicos às próprias ocupaçzes.

(2) Fatores Institucionais: esses fatores referem-se, basicamente, ao papel do salário mínimo e das politicas econômicas na conformação de estrutura de salários e outras rendas.
} 
renda. Essas transformações seriam o deslocamento de trabalhadores para regiões com produtividade mais elevada, a presença de jovens e mulheres no mercado de trabalho e a melhoria do nível educacional da mão-de-obra.

Para esse autor, nos setores tradicionais, o grau de desigualdade estava mais relacionado com o nível de renda do que com a taxa de crescimento, porque a variância na taxa de crescimento não deve ser significativa; o impacto da taxa de crescimento no mercado de trabalho é relativamente pequeno por causa da alta elasticidade da oferta e alto grau de homogeneidade da mão-de-obra empregada; o mercado é relativamente pequeno e imperfeito; e a parcela da desigualdade associada ao capital físico deve estar positivamente correlacionada com o nível de renda.

Nos setores modernos, o grau de desigualdade está mais relacionado ao crescimento, pois, no mercado de trabalho, ocorre uma expansão da demanda por todos os tipos de mão-de-obra, aumentando os diferenciais relativos de salários pela hipótese de que essa oferta é mais inelástica para um maior nível de qualificação, tendência de certa forma reforçada quando ocorre complementaridade entre capital físico moderno e mão-de-obra qualificada.

O desenvolvimento econômico permite um certo grau de concentração de renda pela acumulação do capital humano e/ou físico. Isso se explica pelo fato de que o desenvolvimento caracteriza-se pela transformação de setores tradicionais em setores modernos, existindo uma fase de transição, isto é, de crescimento acelerado. A correlação positiva entre taxa de crescimento e desigualdade deixa de existir à medida que a taxa de crescimento se desacelera.

O principal problema do trabalho de Langoni é concluir que a concentração da renda é um fenômeno autocorrigivel com o processo de desenvolvimento econômico e desconhecer o quadro social e político dos anos 60, que afetou a vida econômica do 
país, através de medidas como política salarial e repressão aos sindicatos. Porém, o estudo é um marco da análise da distribuição da renda na literatura acadêmica, sendo que, posteriormente, vários estudos são elaborados na linha de sua pesquisa ou incorporando variáveis por ele não consideradas.

Destacaram-se, ainda, como aplicações da teoria do capital humano, os trabalhos de Senna (1976) e Castello Branco (1979), que tentam explicar o agravamento da desigualdade da distribuição da renda entre os anos de 1960 e 1970.

Por outro lado, Fishlow (1972) aponta a política econômica adotada a partir de 1964, principalmente a política salarial, como a responsável pelo aumento da concentração da renda.

O estudo de Fishlow (1973) consiste numa crítica ao trabalho de Langoni (1973a e 1973b) sobre as causas da elevação da concentração da renda na década de 1960.

As críticas à tese de Langoni (1973b) sustentam que as modificações na estrutura da força de trabalho provocam maior concentração da renda, dependendo do uso do modelo e das medidas de desigualdade. Assim, o modelo utilizado pode ser inapropriado para captar qualquer influência da política econômica na crescente desigualdade da renda.

Fishlow (1973) apud Tavares (1971) e Furtado (1972) que defendem a tese de que o governo pós-64, ao incentivar a demanda por bens de consumo duráveis, através de políticas creditícias e manipulação dos juros, beneficia determinadas classes sociais e altera a distribuição da renda, idéia que leva à conversão de um resultado ex post numa meta ex ante. 
Convém citar que Singer (1978) concebe a concentração da renda no Brasil como conseqüência direta do processo produtivo vigente no processo de acumulação monopolista no Brasil, que requer inovações tecnológicas e mão-de-obra qualificada, criando um segmento privilegiado da classe média formado por técnicos, administradores e burocratas em geral, que constituem um ótimo mercado para os bens de consumo durável.

Esse autor afirma, ainda, que a concentração de renda no Brasil pós-64 decorre do enfraquecimento da força política dos trabalhadores, possibilitando uma redistribuição de renda para os segmentos mais elevados da pirâmide social brasileira.

Infere-se do exposto que as explicações sobre a distribuição da renda pessoal são complexas e envolvem um conjunto de aspectos diversificados, como a dotação inicial de riqueza, a origem familiar, as decisões de investimento, etc. Não dispomos de uma formulação teórica completa capaz de esclarecer todas as diferenças de renda pessoal no Brasil.

Assim, os vários estudos sobre a desigualdade da distribuição da renda nas décadas de 80 e 90 vão retomar as mudanças qualitativas na composição da PEA (sexo, idade, escolaridade) e a política econômica como variáveis explicativas dessa desigualdade dentro, é claro, de um novo contexto econômico, social e político.

\subsubsection{Condicionantes da distribuição da renda nas décadas de 1980 e 1990}

Vários estudos sobre a desigualdade da distribuição da renda e pobreza nos anos 80 e 90 no Brasil são elaborados, principalmente em linhas de pesquisas centradas na política econômica, que tentam explicar a relação do nível de crescimento econômico e 
os seus aspectos distributivos, considerando-se a seqüência de planos econômicos visando à estabilização ${ }^{11}$.

Revisam-se algumas interpretações sobre os fatores explicativos da desigualdade da distribuição da renda nos anos 80 e 90 , que podem ser esquematizados em:

1. conjunto de fatores sócio-demográficos e econômicos, denominados de "estruturais", em que se destacam os estudos que têm como variáveis a educação e o mercado de trabalho, incluindo as características da força de trabalho em termos do sexo, idade e posição na ocupação;

2. conjunto de fatores conjunturais ou macroeconômicos, que têm como variáveis inflação, salário mínimo, desemprego e taxa de câmbio.

No conjunto de fatores "estruturais" destaca-se o mercado de trabalho que, segundo o IPEA (1996), cumpre o principal papel de gerador de desigualdade na distribuição da renda. Os resultados, comparados com outros países e a posição relativa dos diversos estados no Brasil, apontam a qualidade da força de trabalho e a qualidade dos postos de trabalho (que reflete a produtividade e o poder de barganha do trabalhador e o preço do produto) como os principais fatores determinantes dos diferenciais de renda per capita do Brasil em relação aos países desenvolvidos e entre os diversos estados brasileiros. A pesquisa destaca, ainda, que o padrão de desigualdade observado no país não é de natureza apenas econômica, mas reflete as diferenciações segundo gênero e cor.

O crescimento do mercado de trabalho urbano no Brasil possibilitou a formação de um mercado geral para trabalhadores de baixa ou nenhuma qualificação, combinada com a existência de indústrias com distintos níveis de produtividade e a capacidade

\footnotetext{
${ }^{11}$ Entre os estudos estão o de Barros e Mendonça (1992) e o de Bonelli e Ramos (1993)
} 
diferenciada de pagamento de salários, implicando em trabalhadores mal remunerados e elevada disparidade entre os menores e maiores salários.

O desemprego leva uma parcela da população a se integrar no setor informal em ocupações de baixa remuneração e sem carteira assinada, ficando à margem dos mecanismos de proteção social, dos direitos trabalhistas e da ação dos sindicatos.

Para Oliveira, Porcaro e Jorge (1995), a crise e o processo de ajustamento econômico que caracterizam a década de 1980 no Brasil acentuaram algumas tendências esboçadas nas décadas anteriores e, simultaneamente, introduziram novas e significativas mudanças no perfil do trabalho.

As tendências foram a intensificação do processo de urbanização e o crescimento das ocupações não-agrícolas através do emprego público e das oportunidades de trabalho abertas tanto na prestação de serviços, exclusive serviços domésticos, quanto no comércio em geral.

As transformações operadas no mercado de trabalho entre 1981 e 1990 se traduziram por um crescimento acentuado de atividades que demandaram baixa qualificação, como o comércio ambulante e a prestação de serviços, pela expansão da produção independente em áreas urbanas, por uma participação maior das mulheres na população economicamente ativa e por uma menor proporção de contribuintes à Previdência Social.

Os fatores que contribuíram para a definição desse novo perfil foram a crise e o processo de ajustamento econômico dos anos 80, com a expansão do fenômeno microempresarial, o crescimento do setor informal e as estratégias empresariais de "flexibilização". Os traços distintivos dos anos 90 são a perda da importância relativa do trabalho assalariado em contraposição ao trabalho autônomo, o crescimento de formas 
de "emprego" sem vínculo contratual e uma redução generalizada dos níveis de cobertura social.

O estudo de Sedlacek, Barros e Varandas (1989) enfoca a influência da segmentação do mercado de trabalho brasileiro na desigualdade da distribuição da renda. Os indivíduos com o mesmo potencial produtivo (número de anos de estudo, idade, etc.) recebem salários significativamente diferentes, independentemente das causas da persistência desses diferenciais de salário no tempo. As explicações comuns da origem e persistência da segmentação no mercado de trabalho estão na heterogeneidade das firmas (tecnologia, tamanho, propriedade do capital, grau de imperfeição do produto final, etc.) e nos aspectos institucionais (sindicatos e legislação trabalhista).

Portanto, o mercado de trabalho brasileiro condiciona as diferenciações pessoais da renda e a pobreza no Brasil.

No conjunto de fatores conjunturais destacam-se a inflação e o salário mínimo. O processo inflacionário não é neutro e explica em boa parte a perda do poder aquisitivo da população. As perdas serão maiores para quem tem menor capacidade de se proteger contra o aumento dos preços. Portanto, a inflação se constitui num mecanismo de transferência de renda entre assalariados, empresas, bancos e o Estado.

Segundo o DIEESE (1995), o impacto da inflação sobre a distribuição da renda guarda correspondência direta com a inserção de cada um na economia. Embora ocorra de distintas maneiras, todos aqueles cujos rendimentos não acompanham de perto a elevação dos preços sofrem com isso. É, portanto, inquestionável a perda do valor dos rendimentos do trabalho com a inflação. E é a partir de 1985 , com a aceleração inflacionária e seqüência de planos de estabilização, que as perdas se consolidam, acumulando-se novas perdas a cada fracasso da política econômica. 
A relação entre as mudanças no grau de desigualdade da distribuição da renda no Brasil, no período de 1981/1990, e a intensidade da inflação foi estabelecida por Hoffmann (1992b), obtendo nas equações ajustadas a influência positiva e altamente significativa da inflação sobre a desigualdade.

$\mathrm{O}$ autor distinguiu dois efeitos da inflação acelerada sobre as medidas de desigualdade obtidas a partir dos dados das PNAD, considerando a distribuição da renda entre as pessoas economicamente ativas: um efeito real de aumento da desigualdade devido ao atraso sistemático no reajuste dos rendimentos de certos grupos de pessoas e um efeito denominado de "ruído estatístico", devido à inflação provocar grandes mudanças no valor nominal das remunerações de um mês para outro e erros de declaração em decorrência de as pessoas perderem a noção dos valores monetários. Esses erros aleatórios aumentam a dispersão dos dados e, consequentemente, o grau de desigualdade.

Cardoso, Barros e Urani (1993) analisam a inflação e o desemprego como determinantes da desigualdade da renda no período 1981/1991, considerando as seis áreas metropolitanas. Os autores mostram que a recessão e a megainflação desempenharam seu papel na explicação da elevada desigualdade da renda.

Na opinião de Cardoso (1993), as explicações macroeconômicas são adequadas para esclarecer no curto prazo as variações na distribuição da renda, em que a desigualdade varia ciclicamente e aumenta com a inflação e o desemprego. A legislação do salário mínimo também não tem contribuído para melhorar a distribuição da renda no Brasil.

No que diz respeito ao salário mínimo, a argumentação da autora supracitada é a de que o aumento do salário mínimo real eleva a desigualdade no Brasil, porque esse 
acréscimo reduz o emprego formal e faz crescer o número de trabalhadores recebendo menos que o salário mínimo.

A política do salário mínimo foi introduzida na década de 1940 e passou por profundas modificações ao longo do tempo. O valor do salário mínimo (SM) era, inicialmente, fixado pelo presidente da República, de acordo com os relatórios produzidos pelas comissões tripartites do salário mínimo, que estabeleciam as necessidades básicas do trabalhador urbano.

Com o golpe de 1964, a política do SM muda com a extinção das comissões tripartites. O valor do mínimo passa a ser fixado pelo governo federal independentemente da elevação do custo de vida e do aumento da produtividade da economia.

Esse salário mínimo era limitado aos empregados com carteira de trabalho nas cidades (na década de 1960, a política do salário mínimo incorpora gradualmente os trabalhadores rurais) e diferenciava-se regionalmente. Havia 14 diferentes níveis de salários mínimos, sendo reduzidos paulatinamente até a unificação nacional, em novembro de 1984. A região nordestina se caracterizava pelos menores valores dos salários mínimos e alguns Estados, a partir de 1960, têm seus valores aproximando-se dos níveis de salários mínimos maiores.

Segundo Macedo (1982), no caso do Nordeste brasileiro, a política do salário mínimo objetivou reduzir os diferenciais regionais.

"O Piaui é o caso em que é nítida a tendência de aproximação do salário mínimo de sua capital ao salário mínimo do Rio de Janeiro ou de São Paulo. Assim, o salário mínimo de Teresina, que representava cerca de $42 \%$ do salário mínimo do Rio de Janeiro, passou para 66\% em 1970 e 73\% em 1979." (Macedo, 1982, p.257). 
Conforme dados do DIEESE, na segunda metade dos anos 40 , o poder de compra do SM caiu rapidamente, mas recuperou-se na década de 50, mantendo-se no mesmo nível até 1962, em decorrência da forte presença de interesses sociais organizados. A partir de 1963 começa a decrescer.

Para Pochmann (1994), a política do salário mínimo deixa de ser mecanismo de proteção dos salários dos trabalhadores de base para ser instrumento de combate à inflação, assim como instrumento de equilíbrio das contas públicas das Prefeituras de regiões economicamente atrasadas e da Previdência Social.

O período de 64/70 foi marcado pelo aumento da concentração da renda e a forte pressão sobre os sindicatos, o que achatou a base salarial, ao mesmo tempo em que o crescimento econômico propiciava melhores condições para o aumento dos salários dos trabalhadores mais qualificados ou em melhor posição hierárquica.

A recessão de 1983 coloca cada vez mais a política salarial como a variável de ajuste da política macroeconômica. $O$ fracasso das seguidas experiências de estabilização pós-1986 sempre pressupõem expurgos dos índices de preços, mudanças na política salarial e rompimento de contratos, impondo perdas de renda a cada plano fracassado.

Em síntese, o salário mínimo é um instrumento de garantia de renda mínima ao trabalhador e sua variação interfere no comportamento da desigualdade da renda. A magnitude do impacto na distribuição da renda depende da proporção da população que recebe salário mínimo. 


\subsection{Pobreza e desigualdades regionais}

Lampreia (1995) constatou que a pobreza no Brasil, em particular a indigência ${ }^{12}$, são fenômenos predominantemente rurais e regionais, particularmente expressivos no Nordeste, que se vinculam ao padrão de ocupação produtiva e de desenvolvimento sócio-econômico na área rural.

O IPEA (1996) aponta três focos de pobreza regional: o Nordeste rural, o Nordeste urbano e o Sudeste metropolitano.

A pobreza rural nordestina é a pobreza típica das sociedades tradicionais à margem do crescimento urbano-industrial. Caracteriza-se por tamanho médio das famílias pobres maior que no Sudeste, como também pelo maior número de crianças. A chefia feminina é baixa e a maioria dos chefes de família são analfabetos e ocupados na agropecuária, isto é, na pequena produção agrícola.

No Nordeste urbano, existe uma incidência de pobreza alimentada, em grande medida, pelas migrações internas rurais-urbanas, em que os migrantes, em geral, não são absorvidos pelo mercado de trabalho, ampliando-se o desemprego e o subemprego

As metrópoles do Sudeste estão articuladas com o funcionamento do centro dinâmico da economia nacional. As famílias pobres são menores e o número médio de crianças mais baixo. A chefia feminina é maior que no Nordeste e constitui um traço característico da pobreza urbana em sociedades modernas. A maioria dos pobres trabalha em comércio e serviços. A taxa de desemprego entre os chefes de famílias

\footnotetext{
${ }^{12}$ Lampreia (1995) classificou como pobres aqueles cuja renda, inferior à linha de pobreza, não atendem necessidades básicas de alimentação, moradia, vestuário, etc., indigentes aqueles cuja renda não permite atender nem mesmo às necessidades básicas de alimentação, e não-pobres aqueles cuja renda se situa acima da linha de pobreza.
} 
pobres tem tendência à elevação nas áreas em que o mercado de trabalho é mais formalizado.

Pode-se, portanto, inferir que a diversidade física, econômica e social do Brasil possibilita que a pobreza assuma múltiplos aspectos, identificando-se pólos distintos e opostos em suas características. 


\section{METODOLOGIA}

Os procedimentos metodológicos para estudo da distribuição da renda no Piauí compreendem a discussão da relevância desse tema como um aspecto do grau de desenvolvimento do Estado do Piauí, e a análise empírica da distribuição da renda e pobreza, utilizando as medidas de desigualdade e pobreza para caracterizar o perfil distribuitivo e a pobreza do Estado, a análise de regressão e a decomposição do índice de FGT para obter os fatores explicativos da desigualdade da renda e da pobreza.

Neste capitulo são apresentados os conceitos e métodos estatísticos a serem utilizados e suas dificuldades metodológicas. Além disso, são descritos os dados que serão analisados e suas limitações.

\subsection{Medidas de desigualdade e pobreza}

\subsubsection{Medidas de desigualdade}

Vários métodos são utilizados para medir o grau de desigualdade na distribuição da renda, posse da terra, educação escolar etc. Dentre as medidas de desigualdade estão o Índice de Gini, a Redundância (ou T de Theil) e o L de Theil. 


\subsubsection{Indice de Gini $(G)$}

O índice de Gini é uma medida usada na mensuração do grau de desigualdade de qualquer distribuição estatística. Este índice se associa diretamente com a posição da curva de Lorenz e foi proposto por Corrado Gini (1914). Ao longo deste estudo, será empregado para se medir a desigualdade na distribuição da renda.

Seja uma população de $n$ pessoas (ou famílias) e $x_{i} \quad(i=1,2, \ldots, n)$ o rendimento da $i$-ésima pessoa (família). O rendimento médio é

$$
\mu=\frac{1}{n} \sum_{i=1}^{n} x_{i}
$$

O índice de Gini é expresso por

$$
G=\frac{2}{n^{2} \mu} \sum_{i=1}^{n} i x_{i}-\left(1+\frac{1}{n}\right)
$$

Esse índice varia de $0 \leq G<1$. Quanto mais próximo de 1 , maior será o grau da desigualdade.

O índice de Gini pode ser expresso como uma medida de dispersão relativa:

$$
G=\frac{\Delta}{2 \mu}
$$

sendo $\Delta$ a diferença (absoluta) média dada por 


$$
\Delta=\frac{1}{n^{2}} \sum_{i} \sum_{i}\left|x_{i}-x_{i}\right|
$$

Sen, apud Hoffmann (1991, p.277), diz que esse índice “...apresenta a vantagem de medir diretamente as diferenças de renda, levando em consideração diferenças entre as rendas de todos os pares de indivíduos."

Neste caso o conceito de desigualdade se confunde com o de dispersão relativa. Nesse sentido, cabe destacar a variância dos logaritmos das rendas $\left(V_{z}\right)$, definida como

$$
V_{z}=\frac{1}{n}\left[\sum\left(\ln x_{i}\right)^{2}-\frac{1}{n}\left(\sum \ln x_{i}\right)^{2}\right]
$$

A média geométrica das rendas $(g)$ é $\ln g=\frac{1}{n} \sum \ln x_{i}$

Substituindo (12) em (11) obtém-se

$$
V_{z}=\frac{1}{n} \sum\left(\ln x_{i}-\ln g\right)^{2}=\frac{1}{n} \sum\left(\ln \frac{x_{i}}{g}\right)^{2}
$$

Hoffmann (1997) afirma que é o fato de utilizar-se os logaritmos das rendas que dá à equação. (13) o caráter de uma medida de desigualdade. Se $z=\ln x$, temos $d z=d x / x$, mostrando que uma variação (infinitesimal) em $z$ corresponde uma variação relativa na renda $x . V_{z}$ é função das rendas relativas $\frac{x_{i}}{g}$ e não é definido se houver uma ou mais rendas iguais a zero 
O autor supracitado também aponta o problema da variância dos logaritmos não obedecer à condição de Pigou-Dalton, mas argumenta que essa desvantagem pode ser suprimida se a renda é uma variável com distribuição log-normal ${ }^{13}$.

\subsubsection{2 Índices de Theil}

Para definir as medidas de desigualdade de Theil em função das rendas individuais considere-se um conjunto $n$ de pessoas e seja $x_{i}$ a renda da $i$-ésima pessoa, com $i=1, \ldots, n$ e $\mu$ a renda média. A participação da $i$-ésima pessoa na renda total é

$$
y_{i}=\frac{x_{i}}{n \mu}
$$

A redundância $(R)$ ou $T$ de Theil da distribuição é definida como

$$
T=\sum_{i=1}^{n} y_{i} \ln n y_{i}
$$

Verifica-se que $0 \leq T \leq \ln n$, sendo $T=0$ no caso de distribuição com perfeita igualdade e $R=\ln n$ no caso de distribuição com máxima desigualdade.

Por sua vez, o $\boldsymbol{L}$ de Theil é dado pela fórmula

$$
L=\frac{1}{n} \sum_{i=1}^{n} \ln \frac{1}{n y_{i}}=\frac{1}{n} \sum_{i=1}^{n} \ln \frac{\mu}{x_{i}}
$$

Segue-se que

${ }^{13}$ Consulte Hoffimann (1997, p.197-201) para maiores esclarecimentos. 


$$
L=\ln \left[\frac{1}{n} \sum_{i=1}^{n} x_{i}\right]-\frac{1}{n} \sum_{i=1}^{n} \ln x_{i}=\ln \mu-\ln g
$$

Verifica-se que $0 \leq L<\infty$. $O L$ de Theil não pode ser calculado quando há rendas nulas, pois a média geométrica teria valor zero e o índice não é definido. Se uma das rendas tende a zero, $L$ tende a infinito. Se todas as rendas são iguais (caso de perfeita igualdade), o valor de $L$ é zero.

Como não existe uma medida de desigualdade perfeita, escolhe-se o índice de Gini e o $T$ de Theil para analisar a desigualdade no Piauí, visto que essas medidas são comumente utilizadas na análise acadêmica, permitindo a comparação com outros estudos, e obedecem ao princípio de Pigou-Dalton (equivalente ao critério de Lorenz) ${ }^{14}$.

\subsubsection{Separatrizes e outras medidas}

As separatrizes são valores da renda que dividem a distribuição em determinado número de partes iguais. A mediana, por exemplo, divide a distribuição em duas partes iguais e os nove decis dividem a distribuição em dez partes iguais. A relação entre o $9^{\circ}$ decil e $1^{\circ}$ decil pode ser utilizada como medida de desigualdade.

Outras medidas utilizadas são as proporções da renda total apropriadas por certos grupos da população, como os $50 \%$ mais pobres $\left(50^{-}\right)$, os $10 \%$ mais ricos $\left(10^{+}\right)$e os $5 \%$ mais ricos $\left(5^{+}\right)$. Em termos genéricos, essas medidas de desigualdade são o valor de $100(1-\Phi) \%$ para os $100(1-p) \%$ mais ricas, onde $\Phi$ é a proporção acumulada da renda e $p$ a proporção acumulada da população colocada em ordem crescente de renda.

\footnotetext{
${ }^{14}$ Para esclarecimentos adicionais, consultar Corrêa (1996, p.31-42).
} 
Há, ainda, as medidas decorrentes da composição desses indicadores, como a razão entre a proporção da renda apropriada pelo $1 \%$ mais ricos e os $40 \%$ mais pobres (R $1 / 40)$.

Essas medidas são largamente usadas nas análises sobre o perfil distributivo no Brasil, por serem indicadores simples, de fácil interpretação, e não existir consenso sobre qual seja a medida mais relevante para uma avaliação da distribuição da renda em termos de suas conseqüências econômicas e sociais.

Langoni (1973) considera que para descrever adequadamente o perfil da distribuição da renda é necessário a combinação de índices de desigualdade com estimativas desagregadas dos perfis de renda, como a distribuição por grupos delimitados por percentis.

\subsubsection{Medidas de pobreza}

A pobreza é um fenômeno complexo por envolver várias carências e sua mensuração engloba diferentes metodologias. Segundo Romão (1982), a mensuração da pobreza constitui duas operações distintas e inter-relacionadas: a identificação e a agregação.

O processo de identificação exige estabelecer quem são os pobres, e, para isso, se faz necessário um conceito de pobreza que, pela natureza desse fenômeno, torna-se uma tarefa complicada porque se termina por eleger um determinado conceito que se adapte aos objetivos e dados da pesquisa.

O autor supracitado diz que muitas vezes a pobreza é enfocada pelo ponto de vista meramente subjetivo e contém juízo de valor sobre os limites toleráveis de 
sobrevivência em uma sociedade. Em outras ocasiões, a pobreza é vista pela noção de "privação relativa" ou pela noção, em termos absolutos, que estabelece um padrão mínimo de suficiência para a população, sendo que a proporção desta que não atinge esse padrão é considerada pobre.

O IPEA (1996) diz que o estudo da pobreza é relevante por suas implicações do ponto de vista das políticas públicas, embora seja um fenômeno complexo e relacionado a diversos tipos de carências. A pobreza pode ser mensurada por diferentes metodologias, mas, em geral, está associada à insuficiência de renda. A definição da insuficiência de renda depende da linha de pobreza adotada - parâmetro de valor equivalente ao custo de atendimento de todas as necessidades básicas de um indivíduo em determinado lugar e tempo. Esse valor é superior ao que pode ser associado a uma linha de indigência, que levaria em consideração apenas o custo de atendimento das necessidades alimentares.

A pobreza também pode ser avaliada pelas condições inadequadas de habitação, saneamento, mortalidade infantil, desnutrição, etc.

\subsubsection{Proporção de pobres e insuficiência de renda}

Admita-se uma população com $n$ indivíduos (ou famílias), em que $x_{i}$ (com $i=$ $1, \ldots, n)$ representa a renda do $i$-ésimo indivíduo, supondo que os indivíduos estão ordenados conforme valores crescentes da renda, isto é,

$$
x_{1} \leq x_{2} \leq \ldots \leq x_{n}
$$

Considera-se pobre a pessoa com renda menor ou igual a $z$, sendo o valor de $z$ denominado "linha de pobreza". Neste sentido, se $k$ indivíduos são pobres, então, 


$$
x_{k} \leq z<x_{k+1}
$$

ficando a proporção de pobres na população assim representada:

$$
H=k / n
$$

Verifica-se que $0 \leq H \leq 1$. O valor de $H$ é um indicador da incidência ou extensão da pobreza, mas é totalmente insensível a variações na intensidade dessa pobreza, uma vez que não é afetado quando a renda dos pobres é reduzida. Por outro lado, a razão de insuficiência de renda é dada por

$$
I=\frac{1}{k z} \sum_{i=1}^{k}\left(z-x_{i}\right)
$$

em que $z-x_{i}$ (com $i \leq k$ ) é a insuficiência de renda de um pobre, mostrando em quanto deveria crescer a renda de um pobre para atingir a "linha de pobreza" e $k z$ o valor máximo dessa insuficiência de renda, quando os $k$ pobres tivessem renda nula. A medida $I$ é a razão entre a insuficiência de renda e o seu valor máximo, dado o número de pobres.

$$
\begin{aligned}
& \text { Ora, sendo } \mu^{*} \text { a renda média dos pobres, isto é, } \\
& \mu^{*}=\frac{1}{k} \sum_{i=1}^{k} x_{i}
\end{aligned}
$$

verifica-se que $I=\frac{z-\mu^{*}}{z}$ e $0 \leq I \leq 1$,

com $I=1$ na situação extrema em que todos os pobres têm renda igual a zero. 
A expressão comprova que, dados os valores de $z$ e $\mu^{*}$, o valor da razão de insuficiência de renda é insensivel ao número de pobres, como reitera Hoffmann (1992, p.47):

\footnotetext{
"Se aumentar o número de pobres de uma população, sem que haja alteração na renda média dos pobres, o valor de $H$ aumenta mas a razão de insuficiência de renda (I) permanece inalterada. Por outro lado, se ocorrer uma diminuição da renda média dos pobres, mantendo-se o número de pobres, o valor de $H$ permanece o mesmo e I aumenta. Verifica-se, portanto, que $H$ é sensivel à extensão da pobreza, mas insensivel à intensidade da pobreza, ao passo que $I$ é insensivel à extensão da pobreza e sensivel à intensidade da pobreza."
}

A relação entre a insuficiência de renda e a renda total da população, em porcentagem, resulta da equação

$$
r \%=\frac{100}{n \mu} \sum_{i=1}^{k}\left(z-x_{i}\right)
$$

Essa medida de pobreza fornece o percentual da renda total cuja redistribuição seria necessária para eliminar a pobreza absoluta.

\subsubsection{2 Índice de Pobreza de Sen}

Sen, em 1976, propôs uma medida de pobreza que inclui a desigualdade da distribuição da renda entre os pobres:

$$
P=H\left[I+(1-l) G^{*}\right]
$$


onde $G^{*}$ é o Índice de Gini da desigualdade da distribuição de renda entre os pobres.

Quando os pobres têm renda idêntica, o valor de $G^{*}$ é igual a zero e o Índice de Pobreza de Sen é igual ao produto $H I$. Verifica-se que $0 \leq H I \leq 1$ e que o valor de $H I$ é afetado tanto pela extensão da pobreza (número de pobres) quanto pela intensidade da pobreza, mas não pela redistribuição de renda entre os pobres. Se um montante de renda é transferido de um pobre para outro menos pobre, sem que aquele que recebe a renda adicional deixe de ser pobre, tanto o número de pobres quanto a insuficiência de renda não são alterados e, portanto, o valor de $H I$ permanece o mesmo. O índice de Sen, entretanto, vai aumentar em decorrência dessa transferência regressiva de renda.

\subsubsection{3 Índice de Foster, Greer e Thorbecke (FGT)}

Seja $\boldsymbol{x}=\left(x_{1}, x_{2}, \ldots, x_{n}\right)$ o vetor com as rendas das pessoas em ordem crescente. Fixada a linha de pobreza $z, \operatorname{com} z>0, g_{i}=z-x_{i}$ é a insuficiência de renda da $i$-ésima pessoa. Seja $k=k(x ; z)$ o número de pobres com renda não maior que $z \mathrm{e} n$ o número total de pessoas. A nova medida da pobreza, proposta por Foster, Greer e Thorbecke (1984), genericamente, é

$$
\varphi(\alpha)=\frac{1}{n z^{\alpha}} \sum_{i=1}^{k}\left(z-x_{i}\right)^{\alpha} \quad, \operatorname{com} \alpha \geq 0
$$

Trata-se de uma família de índices em que o parâmetro $\alpha$ pode ser interpretado como um indicador de "aversão à pobreza". Essa medida é igual à proporção dos pobres $(H)$ quando $\alpha=0$ e igual a $H I$ quando $\alpha=1$. 
Segundo Hoffmann (1997, p.241), “Pode-se verificar que $\varphi(\alpha)$, da mesma maneira que o índice de Sen, varia de zero a 1 , com $\varphi(\alpha)=0$ quando todas as pessoas têm renda maior do que z e $\varphi(\alpha)=1$ quando todas as rendas são iguais a zero."

Quando $\alpha=2$, tem-se o indice de Foster, Greer e Thorbecke (FGT) expresso por

$\varphi=\frac{1}{n z^{2}} \sum_{i=1}^{k}\left(z-x_{i}\right)^{2}$

ou $\varphi=H\left[I^{2}+(1-I)^{2} C^{2}\right]$,

onde $C$ é o coeficiente de variação da distribuição da renda entre os pobres, dado por

$$
C^{2}=\frac{1}{k\left(\mu^{*}\right)^{2}} \sum_{i=1}^{k} x_{i}^{2}-1
$$

Portanto, o índice de FGT pode ser expresso como uma função de uma medida de desigualdade entre os pobres, da proporção de pobres e da razão de insuficiência da renda, de maneira semelhante ao que ocorreu com o Índice de Sen. Se não houver desigualdade entre os pobres, têm-se $C=0$ e $\varphi=H I^{2}$.

O índice de FGT apresenta a qualidade de ser decomponível, isto é, quando a população é dividida em grupos, pode-se determinar a contribuição de cada grupo para o total da pobreza. Hoffmann (1995) situa o índice de FGT como um marco no desenvolvimento das medidas de pobreza. 
O efeito do aumento da pobreza em determinado grupo sobre a pobreza global depende da participação da população do grupo no total $\left(n_{j} / n\right)$. Quanto maior a proporção, na população maior o impacto.

A contribuição do grupo no total da pobreza é dado por

$T_{j}=\left(\frac{n_{j}}{n}\right) \varphi_{j}$,

onde $\varphi_{j}$ é a medida de pobreza dentro do j-ésimo grupo, e a percentagem da contribuição do grupo $j$ é estabelecida por

$\frac{100 T_{j}}{\varphi_{j}}$

A decomposição do índice de FGT será aplicada para determinar a contribuição das variáveis situação do domicílio (rural e urbano), sexo, grupos educacionais, idade e condição na ocupação na formação da pobreza.

Observa-se que esse instrumental foi pouco empregado nos estudos sobre a pobreza no Brasil e macrorregiões, citando-se os trabalhos de Ramos (1994) e Hoffmann (1997). Em nível estadual, supõe-se ser esta a primeira aplicação, que pode ser considerada uma contribuição importante para esclarecer os componentes que melhor explicam a pobreza no Piauí, em virtude do Estado apresentar os piores indicadores de pobreza no país.

\subsection{Análise de regressão}

Nesta pesquisa a influência dos fatores estruturais (demográficos e econômicos) no rendimento das pessoas economicamente ativas é captada através do modelo de 
regressão múltipla, incluindo um conjunto de variáveis binárias (que assumem valor 1 ou zero, conforme a característica correspondente seja ou não observada).

A contribuição marginal para a soma de quadrados de regressão mostra a importância de cada fator nas variações no logaritmo do rendimento ( $\boldsymbol{Y}$ ), isto é, o aumento da parte explicada das variações de $\boldsymbol{Y}$ obtido com a introdução da respectiva variável ou grupo de variáveis binárias, depois que todas as demais variáveis já tivessem sido incluídas.

Esta forma funcional log-linear segue as formulações de Langoni (1973), Fishlow (1973), Hoffmann (1993, 1994, 1996 e 1997), Ramos (1993) e Corrêa (1995). Os fatores selecionados foram situação do domicílio, sexo, idade, escolaridade e posição na ocupação, tendo em vista a disponibilidade de dados e os objetivos propostos.

A análise de regressão também é utilizada para verificar a relação funcional do nível absoluto da pobreza com a desigualdade da distribuição da renda, renda média, inflação e salário mínimo, considerando as pessoas economicamente ativas com rendimento.

\subsection{Escolha das variáveis e limitações dos dados}

Hoffmann (1991) assinala que no estudo sobre distribuição da renda as unidades de análise podem ser pessoas economicamente ativas (PEA), pessoas ocupadas, familias ou os próprios domicílios. Por sua vez, as variáveis configuram-se ora como a renda recebida pelas pessoas, ora como a renda familiar, ora como a renda por domicílio, ora como a renda familiar per capita. 
A complexidade do conceito de pobreza ${ }^{15}$ exige que sejam selecionadas algumas variáveis. Assume-se o conceito de pobreza como insuficiência de renda. Nesse caso, são classificados como pobres aqueles com renda igual ou inferior a um valor, denominado "linha de pobreza".

Esse tipo de conceituação detém, segundo o autor supracitado, a desvantagem da renda ser uma medida imperfeita das condições de vida de uma pessoa ou família, apesar de figurar, na economia de mercado, como a principal medida isolada, haja vista que a pobreza não é determinada tão-somente pelo nível de renda, mas também pelas condições de vida de cada família.

Com relação à definição da "linha de pobreza", os estudiosos do assunto questionam qual o critério adequado para defini-la. Nesse sentido, a escolha de um valor é arbitrária, não restando dúvidas de que a opção por uma cesta básica, ou valor do conjunto de bens e serviços considerados essenciais, ou ainda o cálculo de medidas de pobreza para vários valores da "linha de pobreza" possam levar a resultados diferentes.

Hoffmann (1991) considera que nas comparações ao longo do tempo uma alternativa é comparar, em datas distintas, o valor do mesmo conjunto de bens e serviços essenciais. A outra é manter fixo o valor real da "linha de pobreza", utilizando como deflator um índice de custo de vida. Reconhece-se certa dose de arbitrariedade nessa opção, sem contudo diminuir a validade das medidas calculadas. O autor citado considera ideal uma "linha de pobreza" cujo valor real cresça com as variações de despesas decorrentes das novas condições de vida, mas evidencia as dificuldades de sua quantificação.

As linhas de pobreza estimadas no estudo do IPEA (1996) foram feitas segundo regiões e local de residência, a partir de cestas de consumo observadas em famílias de

\footnotetext{
${ }^{15}$ Vide Romão ( 1993 ).
} 
baixa renda nas diversas regiões e dos preços ao consumidor praticados em 1990. A utilização de valores específicos para cada região e local de residência, e não de um único parâmetro nacional, como é mais habitual, tem como objetivo levar em conta as reconhecidas diferenças locais quanto ao custo de vida dos pobres.

Para o estudo da pobreza, como insuficiência de renda, no Piauí, adota-se uma linha de pobreza igual ao maior salário mínimo vigente no país em agosto de 1980 (SM), mantido seu valor real constante ao longo do tempo. A utilização de um único parâmetro possibilita fazer comparações sobre o grau de pobreza absoluta do Piauí com outros estados, a Região Nordeste e Brasil.

O deflator escolhido é o INPC restrito (Índice Nacional de Preço ao Consumidor - IBGE), por ser um índice de custo de vida que tem cobertura nacional e as mudanças na renda média real obtidas com esse índice serem em geral coerentes com as mudanças no Produto Interno Bruto per capita (Hoffmann, 1997). É importante registrar que a escolha de um índice influencia os valores das medidas de pobreza ao longo dos anos, devido ao fato do processo inflacionário brasileiro ter sido intenso e irregular, possibilitando diferenças substanciais entre os diversos índices de preços existentes na economia brasileira.

Nesse estudo são utilizados quatro conjuntos de dados. O primeiro são as informações dos Censos Demográficos de 1960, 1970, 1980, para a população economicamente ativa, objetivando caracterizar a evolução da distribuição da renda e a pobreza desde 1960 .

Os dados referentes à distribuição da renda dos Censos de 970 e 1980, segundo Hoffmann e Kageyama (1986), possuem uma série de limitações. Em primeiro lugar, a subestimação da renda total, devido à coleta via questionários e à própria metodologia, que não computa a produção para autoconsumo. Além disso, registra-se a incorreção 
dos rendimentos percebidos e declarados no mês de referência desses censos. Chamam ainda a atenção para o fato de que tais limitações não afetam, de forma uniforme, todos os estratos de renda. Ao contrário, incidem sobre os extremos da distribuição, o que aumenta a incerteza das medidas de desigualdade calculadas.

Além desses fatores de subestimação da renda total, existe a questão da subdeclaração das rendas altas, deliberadamente ou não. Esta afirmação é respaldada em pesquisas como a de Pfeffermann e Webb (apud Hoffmann e Kageyama, 1986).

Entre outros entraves, está a forma de publicação dos dados, que requer estimativas para cálculo dos índices de desigualdade, sendo necessário fazer pressuposições que podem representar fielmente ou não os fenômenos estudados. Ademais, há dificuldades para a comparação dos dados entre os censos, porque as metodologias de coleta e a apresentação dos dados, muitos vezes, variam bastante.

Outra desvantagem é a subestimação da renda do setor primário e de regiões específicas, bem como a renda real dos empregados domésticos. Aqui, é preciso lembrar que, por toda a complexidade da temática, Hoffmann e Kageyama (1986) remetem a Fishlow e Meesook (1972), para esclarecimentos adicionais.

O segundo conjunto de informações analisadas são as informações individuais de uma Amostra de 0,8\% do Censo Demográfico de 1980. O terceiro são os dados divulgados pelo IBGE das PNAD de 1984 a 1990, 1992, 1993, 1995 e 1996 e o quarto, as informações individuais das PNAD de 1992, 1993 e 1995.

Os dados individuais incluem várias características de cada pessoa da amostra, e seu respectivo peso (ou fator de expansão), que é o número de pessoas da população representado pela pessoa incluída na amostra. Todos os cálculos a partir das informações individuais são feitos ponderando-se cada observação pelo seu respectivo peso. 
É importante destacar as vantagens de se utilizar dados individuais em pesquisas sobre distribuição da renda, ao invés de dados por classes de renda. Na opinião de Langoni (1973a), o problema não é a agregação em classes, mas o desconhecimento $a$ priori da renda total dentro de cada classe que permite calcular a porcentagem de cada grupo da população no total da renda. Porém, mesmo conhecendo a renda total e a renda média, surge o problema de qual método adotar para interpolar os valores entre as classes que permita o cálculo preciso da distribuição por percentis e índices de desigualdade. No geral, a solução desse problema é escolher uma função que descreva adequadamente os dados observados, como as funções clássicas de Pareto (rendas altas) e Log-Normal (rendas baixas).

Assim, a vantagem dos dados individuais é não requerer nenhum ajustamento artificial dos dados originais, podendo-se fazer a ordenação dos indivíduos por nível de renda e sua distribuição pelos percentis. Além do que o perfil da distribuição da renda é praticamente contínuo, evitando a subestimação das medidas de desigualdade.

Os dados da Pesquisa Nacional por Amostra de Domicilios (PNAD) apresentam restrições semelhantes aos dados censitários, com tendência a subdeclarar os rendimentos, especialmente no caso das rendas relativamente elevadas, e omitindo o valor da produção para autoconsumo. Isso faz com que os dados levem a subestimar a renda média e também a desigualdade da distribuição. Apesar dessas limitações, as PNAD são ricas em informações sobre a década de 80 , tendo a vantagem da regularidade anual no periodo de 1981 a 1990 , sem alterações metodológicas ${ }^{16}$.

As características gerais da população economicamente ativa nos anos 90 são analisadas de acordo com os conceitos do IBGE para as PNAD. Cabe, portanto, salientar

\footnotetext{
${ }^{16}$ As PNAD de 1981 a 1990 tiveram cobertura nacional, exceto a área rural da Região Norte. Para maiores esclarecimentos sobre o esquema amostral das PNAD, vide Barros et al (1993, p.750)
} 
as modificações introduzidas no âmbito das características do trabalho e rendimento nas PNAD de 1992, 1993 e 1995.

As PNAD de 1981 a 1990 consideraram como trabalho o exercício de ocupação econômica remunerada em dinheiro, mercadorias, produtos ou somente benefícios, e ocupação sem remuneração na produção de bens e serviços quando exercida normalmente durante pelo menos 15 horas por semana, em ajuda a membro domiciliar que tenha uma atividade econômica ou a instituição religiosa, beneficente ou de cooperativismo, ou, ainda, como aprendiz, estagiário, etc.

Nas PNAD a partir de 1992 a 1996, o trabalho em atividade econômica é definido como o exercício de:

- trabalho remunerado em dinheiro, produto, mercadorias ou benefícios na produção de bens e serviços, e remunerado em dinheiro ou benefícios no serviço doméstico

- trabalho não remunerado desenvolvido pelo menos uma hora na semana

- trabalho na produção para o próprio consumo ou na construção para o próprio uso desenvolvido pelo menos uma hora na semana

A alteração nesse conceito em relação à definição das PNAD de 1981 a 1990 é considerar o trabalho sem remuneração desenvolvido em pelo menos uma hora na semana e o trabalho na produção para o próprio consumo ou na construção para o próprio uso desenvolvido em pelo menos uma hora na semana, elevando o total de pessoas ocupadas e criando as categorias de trabalhador para o próprio consumo e trabalhador na construção para o próprio uso ${ }^{17}$.

\footnotetext{
${ }^{17}$ Para maiores esclarecimentos consultar IBGE (1996, p.XVI).
} 
São consideradas as seguintes categorias de posição na ocupação: empregado (empregado com carteira assinada, militares, funcionários públicos e outro), trabalhador doméstico ( com carteira assinada e sem carteira assinada), conta-própria, empregador, trabalhador não remunerado membro da unidade domiciliar ${ }^{18}$, outro trabalhador não remunerado $^{19}$, trabalhador na produção para o próprio consumo ${ }^{20}$ e trabalhador na construção para o próprio uso ${ }^{21}$.

A mudança de 15 horas de trabalho para apenas uma hora de trabalho vai ocasionar quase inexistência das pessoas desocupadas, reduzindo a taxa de desemprego aberto. Salienta-se que, segundo Silva e Del Grossi (1997), as diferenças entre o atual conceito ampliado de trabalho das novas PNAD e o anterior não afetaram a enumeração dos trabalhadores com rendimento, sejam eles empregados, conta-própria ou empregadores, porque nesse caso as pessoas que trabalharam pelo menos uma hora na semana de referência já eram enumerados. Para os trabalhadores não remunerados a mudança no conceito causa um aumento de cerca de $10 \%$ no seu número.

As pessoas foram classificadas na semana de referência, quanto à condição de ocupação em ocupadas e desocupadas. As pessoas ocupadas foram as que tinham trabalho durante todo ou parte desse período, incluindo-se as pessoas que não exerceram o trabalho remunerado no período especificado por motivos de férias, licença, greve, etc. As pessoas desocupadas foram as sem trabalho que tomaram alguma providência efetiva de procura de trabalho na semana de referência.

\footnotetext{
${ }^{18}$ Definida como a pessoa que trabalhava sem remuneração, durante pelo menos uma hora na semana, em ajuda a membro da unidade domiciliar, que era empregado na produção de bens primários (compreende as atividades da agricultura, silvicultura, pecuária, extração vegetal ou mineral, caça, pesca e piscicultura), conta-própria ou empregador.

${ }^{19}$ Definida como a pessoa que trabalhava sem remuneração, durante pelo menos uma hora na semana, como aprendiz ou estagiário ou em ajuda a instituiçâo religiosa, beneficente ou de cooperativismo.

${ }^{20}$ Definida como a pessoa que trabalhava, durante pelo menos uma hora na semana, na produção de bens do ramo que compreende as atividade da agricultura, silvicultura, pecuária, extração vegetal, pesca e piscicultura, para a própria alimentação ou de pelo menos um membro da unidade domiciliar.

${ }^{21}$ Definida como a pessoa que trabalhava durante pelo menos uma hora na semana, na construção de edificações, estradas privativas, poços e outras benfeitorias (exceto as obras destinadas unicamente à reforma) para o próprio uso ou de pelo menos um membro da unidade domiciliar.
} 
Na condição de atividade, o IBGE classifica as pessoas em economicamente ativas e não economicamente ativas. As pessoas economicamente ativas compuseramse das pessoas ocupadas e desocupadas e as não economicamente ativas foram definidas como as pessoas que não foram classificadas como ocupadas nem desocupadas na semana de referência.

O rendimento mensal de trabalho investigado pelas PNAD de 1992, 1993, 1995 e 1996 constitui-se no valor do rendimento em dinheiro e em produtos ou mercadorias, provenientes do trabalho principal que a pessoa tinha na semana de referência, não sendo investigado o valor da produção para consumo próprio. Os empregados e trabalhadores domésticos que recebiam apenas alimentação, roupas, medicamentos, etc. (benefícios), à guisa de rendimento de trabalho, foram incluídas no grupo sem "rendimento".

O rendimento mensal de outras fontes é constituído pelo rendimento mensal, relativo ao mês de referência, proveniente de aposentadoria, complementação ou suplementação de aposentadoria, pensão, pensão alimentícia, abono de permanência, aluguel e doação ou mesada (proveniente de pessoa não-moradora na unidade familiar) e pelo rendimento médio mensal proveniente de aplicação financeira (juros de papel de renda fixa e de caderneta de poupança, dividendos, etc.), parceria, etc.

A unidade de análise ${ }^{22}$ dessa pesquisa são as pessoas economicamente ativas com rendimento e a variável básica do estudo o rendimento geral das pessoas economicamente ativas (10 anos ou mais) que se constitui na soma do rendimento mensal de trabalho com o rendimento mensal proveniente de outras fontes.

\footnotetext{
${ }^{22}$ Vide em Barros et al (1993, p.753), a tabela 3, que sintetiza as distribuições de renda, unidade de análise, universos de análise e conceitos de renda utilizados nos trabalhos empíicos, de acordo com a disponibilidade das informações existentes
} 
Os fatores sócio-demográficos e econômicos explicativos da desigualdade e pobreza foram selecionadas de acordo com os objetivos propostos e a própria disponibilidade das informações, sendo eles sexo, faixa etária (idade), nível educacional (anos de estudo), posição na ocupação, condição de ocupação do trabalho principal ${ }^{23}$, ramos de atividade, situação do domicílio (urbano e rural) e horas de trabalho.

Assim, vários mecanismos associados à produção da desigualdade de rendimentos pessoais podem ser considerados, como a contribuição de treinamento e experiência, representadas pela educação e idade; a influência de discriminações associadas a sexo (incluindo discriminações salariais no mercado de trabalho e também as limitações impostas às mulheres se forem empregadoras ou autônomas, pelos padrões patriarcais da sociedade brasileira) e os efeitos da distribuição da posse prévia da propriedade e riqueza, conforme representado pela posição na ocupação.

\footnotetext{
${ }^{23}$ Estas atividades são classificados de acordo com a finalidade ou ramo do negócio. As agricolas agrupam agricultura, silvicultura $\mathrm{e}$ pecuária, extração vegetal, pesca e piscicultura, extração mineral. As não-agricolas agrupam indústrias de transformação e construção, serviços industriais de utilidade pública, comércio de mercadorias, Instituições de crédito, de seguros e de capitalização, comércio e administração de imóveis e valores imobiliários, transportes, comunicaçðes, serviços de alojamento e alimentação, serviços de reparação e conservação, serviços pessoais, serviços domiciliares, serviços de diversões, radiodifusão e televisão, serviços técnico-profissionais, serviços auxiliares das atividades econômicas, serviços comunitários e sociais (excluindo-se os serviços médicos, odontológicos, veterinários e de ensino), ensino, administração pública, defesa nacional e segurança pública, organizaçôes internacionais e representações estrangeiras.
} 


\section{DISTRIBUIÇÃO DA RENDA E POBREZA NO ESTADO DO PIAUÍ: 1960, $1970 \mathrm{E} 1980$}

Trabalhos que analisam, especificamente, a distribuição da renda no Estado do Piauí são praticamente inexistentes. Na maioria das vezes, esse tema é tratado como item dos diagnósticos sobre a economia piauiense e se restringe a uma pequena análise de alguns dados publicados das PNAD e Censos Demográficos, como, por exemplo, os estudos de Cavalcante (1978) e Martins et al (1979).

Citam-se, também, os estudos de Hoffmann e Kageyama (1985 e 1986) e Hoffmann (1990, 1992 e 1996) sobre a desigualdade e pobreza no Brasil, que contêm as medidas de desigualdade e pobreza para todas as Unidades da Federação, com o Estado do Piauí se destacando pela sua elevada pobreza, principalmente entre as pessoas ocupadas na agricultura.

\subsection{Configuração da distribuição da renda nas décadas de 1960, 1970 e 1980}

Examinam-se as medidas de desigualdade e pobreza calculadas com base nas informações censitárias de 1960,1970 e 1980 sobre os rendimentos das pessoas economicamente ativas (PEA), incluindo e excluindo os sem rendimentos. As limitações 
dos dados sobre renda publicados nos Censos já foram ventiladas no capítulo metodológico.

A tabela 3 mostra que a renda média foi de $0,42 \mathrm{SM}^{24}$ em 1960,0,56 SM em 1970 e 0,98 SM em 1980 para a PEA, incluindo os sem rendimento. Observa-se que a renda média cresceu $33,3 \%$ no período de 1960 a 1970 e $75,0 \%$ no de 1970 a 1980 .

Tabela 3. Medidas de tendência central, desigualdade e pobreza ${ }^{(1)}$ para população economicamente ativa, incluindo os sem rendimento; Piauí - 1960 - 1970 1980.

\begin{tabular}{l|c|c|c|c|c|c|c|c|c}
\hline ANOS & $\begin{array}{c}\text { Número } \\
\text { de } \\
\text { pessoas }\end{array}$ & $\begin{array}{c}\text { Renda } \\
\text { média } \\
(\mathrm{SM})\end{array}$ & $\begin{array}{c}\text { Mediana } \\
(\mathrm{SM})\end{array}$ & $\begin{array}{c}\text { Indice } \\
\text { de } \\
\text { Gini }\end{array}$ & $\begin{array}{c}\text { Indice } \\
\text { de } \\
\text { Theil }\end{array}$ & $\begin{array}{c}\text { Proporção } \\
\text { de pobres } \\
(\mathrm{H})\end{array}$ & $\begin{array}{c}\text { Razão de } \\
\text { insuficiência } \\
\text { de renda (I) }\end{array}$ & $\begin{array}{c}\text { Indice } \\
\text { de Sen } \\
(\mathrm{P})\end{array}$ & $\begin{array}{c}\text { Índice } \\
\text { de } \\
\text { FGT }\end{array}$ \\
\hline $\mathbf{1 9 6 0}$ & 377.586 & 0,42 & 0,33 & 0,549 & 0,507 & 0,943 & 0,690 & 0,780 & 0,506 \\
$\mathbf{1 9 7 0}$ & 480.632 & 0,56 & 0,41 & 0,572 & 0,558 & 0,911 & 0,643 & 0,724 & 0,442 \\
$\mathbf{1 9 8 0}$ & 656.727 & 0,98 & 0,49 & 0,659 & 0,646 & 0,779 & 0,608 & 0,624 & 0,378 \\
\hline
\end{tabular}

Fonte: IBGE. Dados básicos do Censo Demográfico de 1960, 1970 e 1980.

(1) Linha de pobreza igual a 1 SM em valor real de agosto de 1980.

Por outro lado, eleva-se a desigualdade da distribuição da renda nesses anos. $\mathrm{O}$ índice de Gini cresce de 0,549 (1960) para 0,572 (1970) e 0,659 (1980) e diminui a proporção de pobres de 0,943 (1960) para 0,911 (1970) e 0,779 (1980). Esse decréscimo da pobreza é também verificado pelo índice de FGT, que foi de 0,506 em 1960, 0,442 em 1970 e 0,378 em 1980.

A tabela 4 apresenta as medidas de desigualdade e pobreza para a PEA com rendimento em 1960, 1970 e 1980. Percebe-se que houve um crescimento da renda

\footnotetext{
${ }^{24}$ SM representa aqui o valor real de um salário minimo de agosto de 1980.
} 
média e mediana e das medidas de desigualdade e uma diminuição das medidas de pobreza no período de 1960 a 1980.

Tabela 4. Medidas de tendência central, desigualdade e pobreza ${ }^{(1)}$ para população economicamente ativa, excluindo os sem rendimento; Piauí - 1960, 1970 e 1980.

\begin{tabular}{l|c|c|c|c|c|c|c|c|c}
\hline ANOS & $\begin{array}{c}\text { Número } \\
\text { de } \\
\text { pessoas }\end{array}$ & $\begin{array}{c}\text { Renda } \\
\text { média } \\
(\mathrm{SM})\end{array}$ & $\begin{array}{c}\text { Mediana } \\
(\mathrm{SM})\end{array}$ & $\begin{array}{c}\text { Indice } \\
\text { de } \\
\text { Gini }\end{array}$ & $\begin{array}{c}\text { Indice } \\
\text { de } \\
\text { Theil }\end{array}$ & $\begin{array}{c}\text { Proporção } \\
\text { de pobres } \\
(\mathrm{H})\end{array}$ & $\begin{array}{c}\text { Razão de } \\
\text { insuficiência } \\
\text { de renda (I) }\end{array}$ & $\begin{array}{c}\text { Indice } \\
\text { de Sen } \\
(\mathrm{P})\end{array}$ & $\begin{array}{c}\text { Índice } \\
\text { de } \\
\text { FGT }\end{array}$ \\
\hline $\mathbf{1 9 6 0}$ & 285,724 & 0,56 & 0,39 & 0,404 & 0,348 & 0,924 & 0,583 & 0,635 & 0,347 \\
$\mathbf{1 9 7 0}$ & 390.439 & 0,69 & 0,50 & 0,473 & 0,456 & 0,890 & 0,551 & 0,600 & 0,313 \\
$\mathbf{1 9 8 0}$ & 514.277 & 1,25 & 0,75 & 0,564 & 0,548 & 0,718 & 0,457 & 0,443 & 0,205 \\
\hline
\end{tabular}

Fonte: IBGE. Dados básicos do Censo Demográfico de 1960, 1970 e 1980.

(1) Linha de pobreza igual a 1 SM em valor real de agosto de 1980.

A figura 1 mostra a trajetória das rendas média e mediana entre 1960 e 1980, no Estado do Piauí. A renda média cresceu 81,2\% de 1970 a 1980, enquanto de 1960 a 1970 a variação observada foi de apenas $23,2 \%$. 


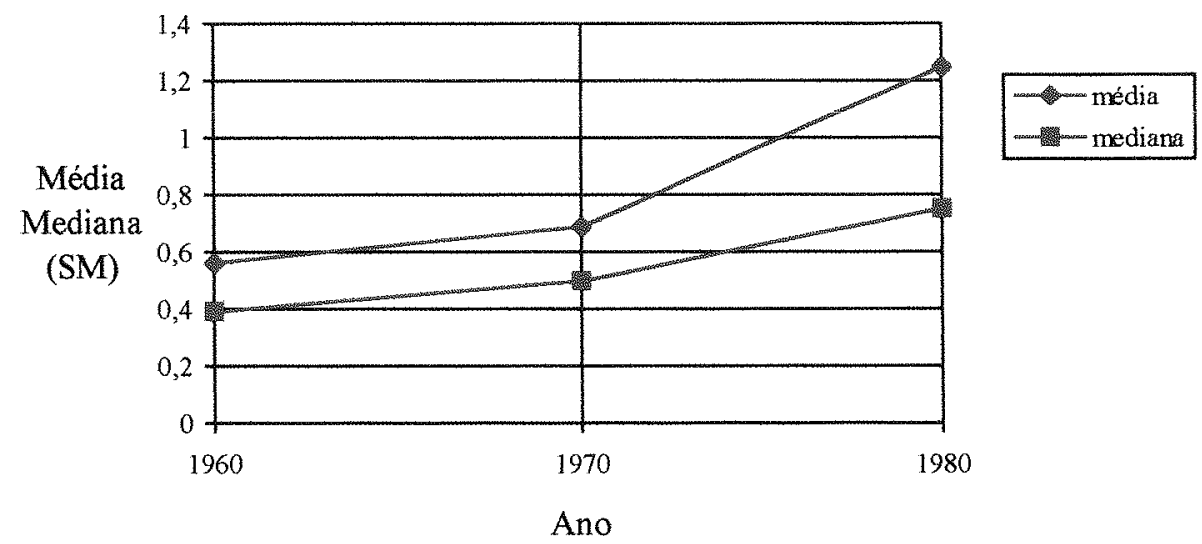

Figura 1. Média e mediana para população economicamente ativa, excluindo os sem rendimento; Piauí - 1960, 1970 e 1980.

O índice de Gini cresce de 0,404 (1960) para 0,473(1970) e 0,564 (1980), e é menor que no Brasil, onde foi de 0,504 (1960), 0,561 (1970) e 0,592 (1980). A desigualdade no Piauí pode ser considerada baixa em 1960 e 1970, visto que o índice de Gini é menor que 0,500, considerando as pessoas economicamente ativas com rendimento. Para o Brasil, esse índice está acima de 0,500.

Verifica-se, por outro lado, que o índice de Gini no Piauí se eleva em $17,3 \%$ de 1960 a 1970 e em $19,2 \%$ de 1970 a 1980 , enquanto no Brasil o crescimento foi de apenas $11,3 \%$ no período de 1960 a 1970 e $5,5 \%$ no de 1970 a 1980 . É claro, portanto, o crescimento mais intenso da desigualdade no Piauí, principalmente no período de 1970 a 1980.

O que chama atenção nesse período é a elevada proporção de pobres - $92,4 \%$ (1960) e $89,0 \%$ (1970) - entre as pessoas economicamente ativas com rendimento, permitindo inferir que o problema mais grave da estrutura da renda no Estado até 1970 é 
a insuficiência de renda, uma vez que no Brasil a proporção de pobres é de apenas $58 \%$ em 1960 e $55 \%$ em 1970.

A figura 5 apresenta o comportamento do índice de Gini, do índice de Sen e do índice de FGT entre 1960 e 1980, em que se visualizam o crescimento da desigualdade e o decréscimo da pobreza.

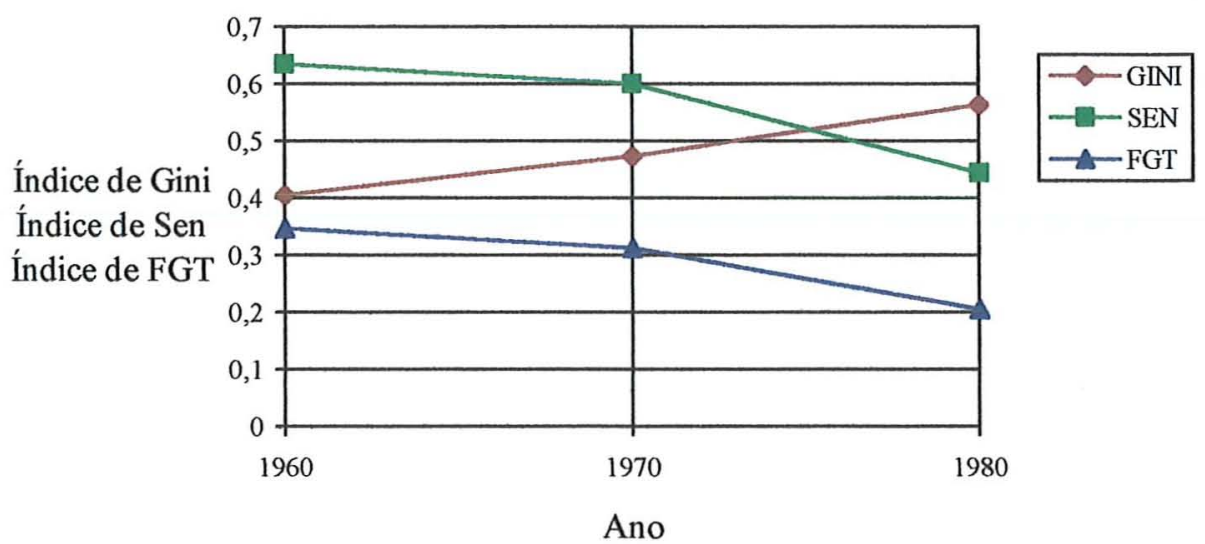

Figura 5. Índice de Gini, índice de Sen e índice de FGT para população economicamente ativa com rendimento; Piauí- 1960, 1970 e 1980.

Em síntese, o Estado do Piauí apresentou baixo índice de desigualdade e elevada pobreza, considerando a PEA com rendimento, em 1960 e 1970 . Já no período de 1970 a 1980 ocorre o crescimento mais intenso da desigualdade da distribuição da renda no Piauí em relação ao Brasil, decorrente não só do crescimento econômico da economia brasileira, mas também das características demográficas e econômicas do Estado.

Conforme mostra a tabela 5 , observa-se um padrão geral de desaceleração demográfica no Piauí, seguindo o padrão brasileiro, em decorrência das quedas contínuas nas taxas de fecundidade. 
Tabela 5. Evolução da população residente e taxa média geométrica de crescimento anual; Piauí - 1960, 1970, 1980 e 1991.

\begin{tabular}{l|c|c|c}
\hline $\begin{array}{c}\text { Data dos recenseamentos } \\
\text { gerais }\end{array}$ & População residente & $\begin{array}{c}\text { Taxa geométrica de } \\
\text { crescimento anual (\%) }\end{array}$ & $\begin{array}{c}\text { Variação da taxa de } \\
\text { crescimento (\%) }\end{array}$ \\
\hline $\begin{array}{l}\text { TOTAL } \\
\text { 01/09/1960 }\end{array}$ & 1.242 .136 & 3,07 & $-20,82$ \\
$01 / 09 / 1970$ & 1.680 .573 & 2,44 & $-29,10$ \\
$01 / 09 / 1980$ & 2.139 .021 & 1,73 & \\
01/09/1991 & 2.582 .137 & & $-18,89$ \\
URBANA & 285.566 & 6,51 & $-26,14$ \\
01/09/1960 & 536.612 & 5,28 & \\
01/09/1970 & 897.994 & 3,90 & $-54,70$ \\
01/09/1980 & 1.367 .184 & & $-123,17$ \\
01/09/1991 & & & \\
RURAL & 956.570 & 1,81 & \\
$01 / 09 / 1960$ & 1.143 .961 & 0,82 & \\
$01 / 09 / 1970$ & 1.241 .027 & $-0,19$ & \\
$01 / 09 / 1980$ & 1.214 .953 & & \\
$01 / 09 / 1991$ & & & \\
\hline
\end{tabular}

Fonte: Dados extraídos de IBGE (1995)

Destaca-se que a população rural corresponde a $77,0 \%$ da população total em 1960 , decrescendo para $68,1 \%$ em 1970 e $58,0 \%$ em 1980 . Outro aspecto é que $47,1 \%$ da população está concentrada na faixa etária de 0 a 14 anos em 1960, 47,6\% em 1970 e $45,5 \%$ em 1980, sendo significativo o peso relativo de jovens na população total. Informa-se, ainda, que em 1980 as taxas de analfabetismo, segundo IBGE (1995), são $49,5 \%$ no total, $29,5 \%$ na área urbana e $65,1 \%$ na rural.

O comportamento da população economicamente ativa, no Piaú, está representado na tabela 6. De 1960 a 1980 a PEA agrícola diminui sua participação relativa, passando de $74,2 \%$ para $62,3 \%$, embora se mantenha como o setor em que a maioria das pessoas ocupadas estão inseridas. A indústria, caracterizada pela 
predominância de microempresas familiares e artesanais, participa com 6,6\% em $1960 \mathrm{e}$ $9 \%$ em 1980. Por outro lado, a presença do setor serviços se fortalece, sobretudo quanto ao setor informal, mantendo os seguintes percentuais: $19,2 \%$, em 1960, e $28,7 \%$, em 1980. Existe uma tendência de crescimento da PEA na indústria, na medida que mostra uma taxa de crescimento de $11,6 \%$ no período $70 / 80$. Nesse período, a taxa de crescimento é apenas $1,5 \%$ na agricultura e $4 \%$ no setor de serviços.

Tabela 6. População economicamente ativa (PEA) do Piauí, conforme os setores produtivos; 1960/1980.

\begin{tabular}{l|c|c|c|c}
\hline $\begin{array}{c}\text { Discriminação da população } \\
\text { economicamente ativa }\end{array}$ & Agricultura & Indústria & Serviços & Total \\
\hline 1960 & 281.039 & 25.071 & 72.783 & 378.893 \\
1970 & 334.473 & 26.016 & 124.177 & 484.666 \\
1980 & 390.882 & 56.426 & 179.626 & 626.934 \\
Distribuição percentual (\%) & 74,2 & 6,6 & 19,2 & 100,0 \\
1960 & 69,0 & 5,4 & 25,6 & 100,0 \\
1970 & 62,3 & 9,0 & 28,7 & 100,0 \\
1980 & & & & \\
Taxa crescimento anual(\%) & 1,7 & 0,4 & 5,5 & 2,5 \\
1960 a 1970 & 1,5 & 11,6 & 4,0 & 5,3 \\
\hline 1970 a 1980 & & & & \\
\hline
\end{tabular}

Fonte: Dados extraidos de Santos (1995).

A tabela 7 mostra a variação percentual do PIB no Brasil, Nordeste e Piauí, verificando-se que o maior crescimento percentual do PIB no Piauí é no período de 1970 a $1975(60,8 \%)$, acima da variação nordestina, de 54,5\%, e abaixo da brasileira, de $63,2 \%$. 
Tabela 7. Variação percentual do PIB do Brasil, Região Nordeste e Estados nos quinquênios 1960-65, 1965-70, 1970-75, 1975-80.

\begin{tabular}{c|c|c|c|c|}
\hline Unidade & \multicolumn{3}{|c}{ Quinquênios } \\
\cline { 2 - 5 } & $1960-65$ & $1965-70$ & $1970-75$ & $1975-80$ \\
\hline NORDESTE & 27,1 & 17,4 & 54,5 & 51,9 \\
Maranhão & 20,1 & 19,1 & 46,0 & 60,4 \\
PIAỨ & 46,0 & $\mathbf{2 0 , 0}$ & $\mathbf{6 0 , 8}$ & $\mathbf{4 4 , 4}$ \\
Ceará & 40,8 & 0,4 & 46,1 & 63,3 \\
Rio Grande do Norte & 26,8 & $-9,0$ & 80,5 & 48,7 \\
Paraíba & 24,0 & $-20,3$ & 59,4 & 31,1 \\
Pernambuco & 32,8 & 15,9 & 49,1 & 33,3 \\
Alagoas & 22,4 & 32,8 & 45,5 & 51,6 \\
Sergipe & 31,0 & 28,2 & 51,2 & 36,0 \\
Bahia & 17,7 & 41,7 & 60,4 & 66,7 \\
BRASIL & 23,3 & 47,4 & 63,2 & 40,8 \\
\hline
\end{tabular}

Fonte: Dados do PIB a custo de fatores dos Estados, Região Nordeste e Brasil (em US\$ 1,000,00 constantes de 1995) extraidos de Azzoni (1997, p.380-383).

O comportamento do PIB piauiense reflete sua estrutura econômica, baseada, até o final da década de 1950, segundo Martins et al (1978), na pecuária extensiva, extrativismo e agricultura de subsistência. Essas atividades caracterizavam-se pela pequena divisão social de trabalho, mercado consumidor restrito e agricultura voltada, de início, somente para autoconsumo.

Destaca-se que o extrativismo exportador causou certo dinamismo na economia piauiense, fortalecendo as finanças públicas, propiciando melhoramentos urbanos $\mathrm{e}$ intensificado o processo de urbanização de Teresina e Parnaíba.

A economia piauiense é marcada pela multiplicação da pequena produção agrícola, como resultado do decréscimo da produção extrativa até a década de 1970. Para Domingos Neto (1983), a criação extensiva de bovinos e a exploração extrativa perdem importância frente às roças.

De acordo com Martins et al (1978), Bandeira (1983), Rocha (1988) e Santos (1995), a economia piauiense, no período de 1970 a 1980 , se caracteriza por 
investimentos em infra-estrutura básica (estradas, energia, abastecimento d'água, eletrificação, telecomunicações, etc.), bem como por ascendente participação das transferências federais nas receitas do Estado. O Piauí continua a importar grande parte dos seus produtos agrícolas e pecuários.

Rocha (1988), entretanto, chama a atenção para a intensificação do processo de concentração de terras a partir de 1970 , devido a elementos variados, quais sejam: incentivos fiscais vindos da Superintendência do Desenvolvimento do Nordeste (SUDENE); política de crédito agrícola subsidiado; medidas de combate às secas; grilagem; alienação de grandes extensões de terra pertencentes ao Estado; programa Proálcool; incentivos do atual Instituto Brasileiro do Meio Ambiente e Recursos Naturais Renováveis (IBAMA), na época, Instituto Brasileiro de Desenvolvimento Florestal (IBDF), visando ao reflorestamento e à implantação de infra-estrutura física, o que estimula novas grandes propriedades de cidadãos vindos de outras regiões ou de outros estados, reduzindo mais as perspectivas de acesso à terra pelos pequenos produtores.

Mesmo com esses aparentes incentivos, o Piauí não incorpora a modernização da agricultura que vem se processando no Brasil. Por isso é, no mínimo, conclusão precipitada, segundo Domingos Neto (1983), considerar a agricultura piauiense modernizada, pois seu grau de transformação é pequeno e visualizado apenas em algumas culturas alimentares e em áreas privilegiadas por algum programa governamental. Portanto, qualquer indicador de modernização só se sustenta nas zonas beneficiadas por grandes projetos agropecuários financiados pela SUDENE e/ou por iniciativas de reflorestamento do IBAMA.

Outro aspecto a considerar, dentro das características econômicas do Estado do Piauí, é a formação do seu de trabalho. As particularidades desse mercado são 
apontadas, de maneira unânime, pelas várias pesquisas no Brasil e Nordeste, como um dos fatores responsáveis pela má distribuição da renda.

Nessa perspectiva, os elementos que formam o mercado de trabalho no Piauí, segundo Lopes (1996), surgiram com o extrativismo. Essa atividade permitiu uma incipiente acumulação de capital, criando as condições para a conformação de um frágil mercado de trabalho, dentro de processo de urbanização e avanço da divisão social do trabalho. Tal mercado de trabalho se estrutura com o crescimento populacional, ação do setor público e consolidação de alguns núcleos populacionais, como Teresina (capital).

$\mathrm{Na}$ agricultura predomina a parceria (meação, etc.), tendo menor importância o assalariamento. Isso está associado à elevada concentração da terra, que marca a estrutura fundiária do estado. Nas cidades, a mercantilização da força de trabalho é restrita pelo reduzido mercado interno, mas se destaca a presença do Estado como agente absorvedor de força de trabalho, estimulando o emprego no setor serviços e expandindo a camada intermediária e o consumo urbano.

É, pois, esse contexto demográfico e econômico que subsidia a compreensão da configuração da distribuição da renda em 1960, 1970 e 1980.

\subsection{A desigualdade e a pobreza em 1980: análise dos dados individuais}

A configuração da distribuição da renda e pobreza em 1980 pode ser melhor esclarecida através dos dados individuais da amostra de $0,8 \%$ do Censo Demográfico de 1980. A tabela 8 apresenta as medidas de desigualdade e pobreza entre as pessoas economicamente ativas, incluindo os sem rendimento. A participação relativa das pessoas no setor agrícola é de $61,2 \%$ e, nos setores urbanos (ou não-agrícola), 38,8\%. 
Essa concentração da PEA na agropecuária determina o baixo rendimento e influencia a distribuição da renda.

Tabela 8. Medidas de desigualdade e pobreza para as pessoas economicamente ativas, incluindo os sem rendimento, por setores; Piauí - 1980.

\begin{tabular}{|c|c|c|c|c|c|c|c|c|}
\hline Setores & $\begin{array}{c}\text { Número } \\
\text { de } \\
\text { pessoas }\end{array}$ & $\begin{array}{l}\text { Renda } \\
\text { média }\end{array}$ & $\begin{array}{l}\text { Indice } \\
\text { de Gini } \\
(G)\end{array}$ & $\begin{array}{l}\text { Indice } \\
\text { de Theil } \\
\text { (T) }\end{array}$ & $\begin{array}{c}\text { Proporção } \\
\text { de pobres } \\
(\mathrm{H})\end{array}$ & $\begin{array}{c}\text { Razão de } \\
\text { insuficiência } \\
\text { de renda (I) }\end{array}$ & $\begin{array}{l}\text { Indice } \\
\text { de Sen } \\
\text { (P) }\end{array}$ & $\begin{array}{c}\text { Índice } \\
\text { de } \\
\text { FGT }\end{array}$ \\
\hline Agrícola & 389.330 & 0,47 & 0,622 & 0,568 & 0,907 & 0,692 & 0,781 & 0,518 \\
\hline Urbanos $^{(1)}$ & 247.304 & 1,82 & 0,609 & 0,581 & 0,576 & 0,452 & 0,360 & 0,171 \\
\hline TOTAL & $636.634^{(2)}$ & 0,98 & 0,673 & 0,661 & 0,781 & 0,648 & 0,634 & 0,391 \\
\hline
\end{tabular}

Fonte: IBGE. Dados individuais da Amostra de 0,8\% do Censo Demográfico de 1980.

Nota: Sem declaração de 13.763 pessoas.

(1) Os setores urbanos se compõem de todas as atividades não-agrícolas.

A desigualdade da distribuição da renda e a pobreza são mais elevadas no setor agrícola, como se verifica pelos índices de Gini $(0,622)$ e de Sen $(0,781)$. Entretanto, quando se considera o índice de Theil, a desigualdade da distribuição é maior nos setores urbanos $(0,581)$ do que no agrícola $(0,568)$.

A tabela 9 registra as medidas de desigualdade e pobreza para a PEA com rendimento nos setores agrícola e urbanos, em que o índice de Gini é igual a 0,433 e 0,602 , e índice de FGT igual a 0,278 e 0,156 , respectivamente, indicando baixa desigualdade e alta pobreza no setor agrícola e alta desigualdade e pobreza menor do que no setor agrícola, nos setores urbanos ${ }^{25}$.

\footnotetext{
${ }^{25}$ Hoffmann (1982) verifica, com base nas Tabulaçốes Avançadas do Censo Demográfico de 1980, que não se pode dizer que o elevado grau de desigualdade da distribuição da renda no Brasil seja devido, em grande parte, à desigualdade rural-urbana, porque apenas $6,4 \%$ da redundância da renda entre as pessoas de 10 anos ou mais com rendimento se deve à desigualdade rural-urbana e $93,6 \%$ se deve à desigualdade dentro dessas áreas.
} 
Tabela 9. Medidas de desigualdade e pobreza para as pessoas economicamente ativas com rendimento, por setores; Piauí - 1980.

\begin{tabular}{l|l|c|c|c|c|c|c|c}
\hline Setores & $\begin{array}{c}\text { Número } \\
\text { de } \\
\text { pessoas }\end{array}$ & $\begin{array}{c}\text { Renda } \\
\text { média }\end{array}$ & $\begin{array}{c}\text { Indice } \\
\text { de Gini } \\
(\mathrm{G})\end{array}$ & $\begin{array}{c}\text { Indice } \\
\text { de Theil } \\
(\mathrm{T})\end{array}$ & $\begin{array}{c}\text { Proporção } \\
\text { de pobres } \\
(\mathrm{H})\end{array}$ & $\begin{array}{c}\text { Razão de } \\
\text { insuficiência } \\
\text { de renda }(\mathrm{I})\end{array}$ & $\begin{array}{c}\text { Indice } \\
\text { de Sen } \\
(\mathrm{P})\end{array}$ & $\begin{array}{c}\text { Indice } \\
\text { de } \\
\text { FGT }\end{array}$ \\
\hline $\begin{array}{l}\text { Agricola } \\
\text { Urbanos }^{(1)}\end{array}$ & 259.721 & 0,71 & 0,433 & 0,352 & 0,860 & 0,513 & 0,562 & 0,278 \\
TOTAL & 242.898 & 1,84 & 0,602 & 0,574 & 0,569 & 0,434 & 0,342 & 0,156 \\
& $502.619^{(2)}$ & 1,25 & 0,581 & 0,565 & 0,720 & 0,482 & 0,457 & 0,218 \\
\hline
\end{tabular}

Fonte: IBGE. Dados individuais da Amostra de 0,8\% do Censo Demográfico de 1980.

Nota: Sem declaração de 4.646 pessoas.

(1).Os setores urbanos se compãem de todas as atividades não-agrícolas.

Os fatores que mais contribuíram para a pobreza em 1980 são analisados através da decomposição do índice de FGT, aplicada aos dados da amostra de $0,8 \%$ do Censo Demográfico de 1980, considerando-se os setores agrícola e urbanos, e o sexo (masculino e feminino).

As tabelas 10 e 11 revelam a contribuição de cada fator considerado no total da pobreza. O setor agrícola contribuiu com $66 \%$ no total da pobreza e os setores urbanos $34 \%$, visto que $51,7 \%$ da PEA com rendimento encontra-se na agropecuária. A pobreza piauiense é, assim, de natureza essencialmente rural, como se pode observar pela proporção de pobres na agropecuária $(86 \%)$ e nos setores urbanos $(56,9 \%)$. Este indicador reafirma o Piauí como um foco de pobreza rural. 
Tabela 10. Decomposição da medida de pobreza (índice de FGT) por setores; Piauí1980.

\begin{tabular}{|c|c|c|c|c|c|}
\hline Setores & $\begin{array}{l}\text { Número de } \\
\text { pessoas }\end{array}$ & $\begin{array}{c}\text { Indice de } \\
\text { FGT } \\
(\varphi)\end{array}$ & $\begin{array}{c}\text { Contribuição no } \\
\text { total da pobreza } \\
(\%)\end{array}$ & $\begin{array}{l}\text { Renda } \\
\text { média do } \\
\text { pobre }\end{array}$ & $\begin{array}{l}\text { Proporção de } \\
\text { pobres em cada } \\
\text { grupo }\end{array}$ \\
\hline Urbanos ${ }^{(1)}$ & 242.898 & 0,156 & 34,0 & 0,57 & 0,569 \\
\hline Agrícola & 259.721 & 0,278 & 66,0 & 0,49 & 0,860 \\
\hline TOTAL & $502.619^{(3)}$ & 0,218 & 100,0 & 0,52 & 0,720 \\
\hline
\end{tabular}

Fonte: IBGE. Dados individuais da Amostra de 0,8\% do Censo Demográfico de 1980.

Nota: Sem declaração de 4.646 pessoas.

(1) Inclui todas as atividades não-agrícolas. (2) Em SM/ago.80, igual a Cr\$4.149,6.

Tabela 11. Decomposição da medida de pobreza (índice de FGT) por sexo; Piauí 1980.

\begin{tabular}{l|c|c|c|c|c}
\hline Sexo & $\begin{array}{c}\text { Número de } \\
\text { pessoas }\end{array}$ & $\begin{array}{c}\text { Indice de } \\
\text { FGT } \\
(\varphi)\end{array}$ & $\begin{array}{c}\text { Contribuição no } \\
\text { total da pobreza } \\
(\%)\end{array}$ & $\begin{array}{c}\text { Renda média } \\
\text { do pobre }\end{array}$ & $\begin{array}{c}\text { Proporção de } \\
\text { pobres em cada } \\
\text { grupo }\end{array}$ \\
\hline Homem & 380.737 & 0,176 & 60,4 & 0,56 & 0,695 \\
Mulher & 126.527 & 0,347 & 39,6 & 0,40 & 0,795 \\
TOTAL & 507.265 & 0,218 & 100,0 & 0,52 & 0,720 \\
\hline
\end{tabular}

Fonte: IBGE. Dados individuais da Amostra de 0,8\% do Censo Demográfico de 1980.

(1) em SM/ago.80, igual a Cr\$4.149,6

No que diz respeito ao sexo, a freqüência relativa dos homens no total da PEA com rendimento é de $75,1 \% \mathrm{e}$, das mulheres, $24,9 \%$. Os homens contribuíram em $60,4 \%$ e as mulheres em $39,6 \%$ na pobreza. Portanto, a PEA com rendimento tem 3 vezes mais homens do que mulheres. Por outro lado, a proporção de mulheres pobres é superior $(79,5 \%)$ à proporção de homens pobres $(69,5 \%)$.

Em resumo, os dados analisados para os anos de 1960, 1970 e 1980 permitem inferir que o crescimento da desigualdade da distribuição da renda no Piauí foi mais 
intenso que a elevação da desigualdade no Brasil, apesar do crescimento maior da renda média, fazendo com que a redução da pobreza absoluta seja menor do que a que ocorreu nacionalmente, delineando a tendência de que num estado atrasado como o Piaú os pobres são menos beneficiados pelo crescimento da renda.

Há, no Piauí, essencialmente, uma pobreza rural, conforme as características demográficas e econômicas apontadas anteriormente, que se compatibilizam com as características traçadas nos estudos do IPEA (1995) e Alburquerque (1995) para o Nordeste rural. Esta pobreza é típica das sociedades atrasadas, em que a PEA com rendimento desenvolve atividade agrícola de subsistência e possui baixa escolaridade.

No que diz respeito à diminuição da pobreza, as mudanças demográficas e produtivas que se processaram ao longo das décadas, principalmente a crescente urbanização, apesar de agravar os problemas nas cidades e criar um foco de pobreza urbana, em especial na capital (Teresina) e nas cidades de médio porte (Parnaiba, Floriano, Picos e Campo Maior), de certa forma consegue diminuir os níveis de pobreza, porque a população em área urbana tem acesso aos serviços públicos, que, embora em níveis insatisfatórios, atendem, relativamente, melhor do que no campo, onde sequer existem, e participa do mercado informal de trabalho, obtendo algum tipo de renda monetária.

Portanto, dados censitários de 1960, 1970 e 1980 mostraram uma crescente desigualdade na distribuição da renda e um percentual em torno de $90 \%$ de pobres entre as pessoas economicamente ativas, podendo-se inferir que a insuficiência de renda decorre tanto das características demográficas, quanto das econômicas do Estado do Piauí. 
4.2.1 Condicionantes sócio-demográficos e econômicos da desigualdade da distribuição da renda

Os condicionantes "estruturais" da distribuição da renda são analisados com base nos dados da amostra de $0,8 \%$ do Censo Demográfico de 1980. Os fatores "estruturais" selecionados foram o sexo, a idade, a escolaridade, a posição na ocupação e o setor, o que caracteriza o mercado de trabalho no Piauí, devido a se ter tomado, como unidade de análise, a pessoa economicamente ativa com rendimento.

A influência destes fatores no rendimento das pessoas economicamente ativas foi captada por meio de uma regressão múltipla, utilizando conjuntos de variáveis binárias definidas da seguinte forma:

1. uma variável binária para distinguir os dois sexos, indicada por $S$.

2. um conjunto de 8 variáveis binárias para as 9 faixas de idade: 10 a 14 anos, 15 a 17 anos, 18 a 19 anos, 20 a 24 anos, 25 a 29 anos, 30 a 39 anos, 40 a 49 anos, 50 a 59 anos e 60 anos e mais, representadas por $D_{i}, \operatorname{com} i=1, \ldots, 8$.

3. um conjunto de 7 variáveis binárias para captar 8 níveis de escolaridade (anos de estudo): sem instrução ou menos de um ano, 1 ano, 2 anos, 3 anos, 4 anos, 5 a 8 anos, 9 a 11 anos, 12 anos e mais), indicadas por $E_{j}, \operatorname{com} j=1, \ldots, 7$.

4. quatro variáveis binárias para distinguir 5 categorias de posição na ocupação: sem remuneração, trabalhador agrícola volante, empregado (incluindo parceiro empregado), conta-própria (ou autônomo, incluindo parceiro conta-própria), empregador (incluindo parceiro empregador ), indicadas por $P_{h}, \operatorname{com} h=1, \ldots, 4$.

5. duas varáveis binárias para distinguir os três setores: agrícola (agricultura, silvicultura, pecuária, extração vegetal, pesca e piscicultura), indústria (indústrias de transformação, extração mineral, construção e serviços) e serviços (comércio, transporte, comunicação, serviço de ensino e administração pública), indicadas por $T_{m}$, com $m=1,2$. 
A equação de rendimentos é expressa por

$Y=\alpha+\beta S+\sum_{i=1}^{8} \gamma_{i} D_{i}+\sum_{j=1}^{7} \omega_{j} E_{j}+\sum_{h=1}^{4} \theta_{h} P_{h}+\sum_{m=1}^{2} \lambda_{m} T_{m}+u$

onde $u$ é um erro aleatório que representa os efeitos de todas as demais variáveis que afetem o logaritmo do rendimento $(Y)$ e não foram incluídas no modelo.

O modelo foi ajustado pelo método de mínimos quadrados ponderados, usando, como fator de ponderação, o fator de expansão fornecido pelo IBGE para cada pessoa da amostra. $\mathrm{O}$ ajuste do modelo é feito apenas para a PEA com rendimento positivo e com informação válida para todas as variáveis exploratórias consideradas.

Os coeficientes estimados das variáveis explanatórias podem ser interpretados como a diferença no valor esperado de $Y$ para a categoria onde a variável é 1 em relação à categoria tomada como base. $O$ termo constante representa o valor esperado de $Y$ na categoria tomada como base, que corresponde a pessoas do sexo feminino, com 10 a 14 anos de idade, menos de um ano de escolaridade, cuja posição na ocupação é de empregado e está ocupado na agricultura. A tabela 12 apresenta os coeficientes da equação de regressão ajustada, os valores de $t$ e números-índices.

Todos os fatores considerados (setor, sexo, idade, escolaridade e posição na ocupação) mostraram influência estatisticamente significativa ao nível de $1 \%$. $\mathrm{O}$ coeficiente de determinação indica que a equação de regressão explica 46,2\% das variações do logaritmo do rendimento das pessoas. Como o rendimento individual possui partes aleatórias e afetadas por características pessoais cuja mensuração é praticamente impossível (ambição, tino comercial, etc.), coeficientes de determinação nessa ordem de grandeza ou menores são usuais nesse tipo de análise. 
Tabela 12. Coeficientes da equação de rendimento ajustada, valores $t$ e númerosíndices ${ }^{(1)}$; Piauí- 1980.

\begin{tabular}{|c|c|c|c|}
\hline Fatores & Coeficientes estimados & Valores de $t^{(2)}$ & Números-índices $^{(3}$ \\
\hline \multicolumn{4}{|l|}{ SETOR } \\
\hline serviços & 0,540 & $17,51^{*}$ & 172 \\
\hline indústria & 0,567 & $16,93^{*}$ & 176 \\
\hline agricultura & 0,000 & & 100 \\
\hline \multicolumn{4}{|l|}{ SEXO } \\
\hline Homem & 0,867 & $35,54 *$ & 238 \\
\hline Mulher & 0,000 & & 100 \\
\hline \multicolumn{4}{|l|}{ IDADE } \\
\hline 10 a 14 anos & 0,000 & & 100 \\
\hline 15 a 17 anos & 0,234 & 3,31 草 & 126 \\
\hline 18 a 19 anos & 0,354 & $4,91 *$ & 142 \\
\hline 20 a 24 anos & 0,608 & $9,52^{*}$ & 184 \\
\hline 25 a 29 anos & 0,793 & 12,31 & 221 \\
\hline 30 a 39 anos & 0,974 & $15,60 *$ & 265 \\
\hline 40 a 49 anos & 1,093 & 17,21 * & 298 \\
\hline 50 a 59 anos & 1,031 & $15,68 *$ & 280 \\
\hline 60 anos ou mais & 1,093 & $15,55 *$ & 298 \\
\hline \multicolumn{4}{|l|}{ ESCOLARIDADE } \\
\hline sem instrução e menos de 1 ano & 0,000 & & 100 \\
\hline 1 ano & 0,081 & 1,74 & 108 \\
\hline 2 anos & 0,152 & $3,92 *$ & 116 \\
\hline 3 anos & 0,223 & $5,73^{\star}$ & 125 \\
\hline 4 anos & 0,407 & $11,79^{\star}$ & 150 \\
\hline 5 a 8 anos & 0,553 & $13,48 *$ & 174 \\
\hline 9 a 11 anos & 1,219 & $28,79 *$ & 338 \\
\hline 12 anos ou mais & 2,244 & 29,03 & 943 \\
\hline \multicolumn{4}{|l|}{ POSIÇÃO NA OCUPAÇÃO } \\
\hline sem remuneração & $-0,069$ & $-0,28$ & 93 \\
\hline trabalhador agrícola volante ${ }^{(4)}$ & 0,310 & $5,74 *$ & 136 \\
\hline empregado (s) & 0,000 & & 100 \\
\hline conta- própria ${ }^{(6)}$ & 0,088 & $3,25 *$ & 109 \\
\hline empregador $(7)$ & 1,062 & $14,68 *$ & 289 \\
\hline
\end{tabular}

Fonte: IBGE. Dados individuais da Amostra de 0,8\% do Censo Demográfico de 1980.

(1) Resultados do Procedure GLM/SAS. (2) Todos os coeficientes assinalados com (*) são estatisticamente significativos ao nivel de $5 \%$. (3) Se $\beta$ é um coeficiente estimado da equação de rendimentos, o número-índice é $100 \exp (\beta)$. (4) Trabalhador agricola volante com intermediário e trabalhador agricola volante sem intermediário. (5) Parceiro/empregado e empregado. (6) Parceiro/conta-própria e conta-própria. (7) Parceiro/empregador e empregador.

A contribuição marginal avalia a importância de cada fator nas variações no logaritmo do rendimento $(Y)$, isto é, o aumento da parte explicada das variações de $Y$ obtido com a introdução da respectiva variável ou grupo de variáveis binárias, depois que todas as demais variáveis já tivessem sido incluídas. No modelo geral ajustado, o setor contribuiu com $7,6 \%$, o sexo com $23,9 \%$, a idade com $16,1 \%$, a posição na ocupação com $4,5 \%$ e a escolaridade com $26,6 \%$. 
As estimativas dos diferenciais de rendimento associados ao sexo, à idade, à escolaridade e à posição na ocupação obtidas ajustando regressões distintas para cada um dos três setores estão registradas na tabela 13

Tabela 13. Coeficientes das equações de rendimento ajustadas para cada setor; Piauí1980

\begin{tabular}{|c|c|c|c|c|c|c|}
\hline \multirow[t]{2}{*}{ FATORES } & \multicolumn{2}{|c|}{ AGRICOLA } & \multicolumn{2}{|c|}{ INDÚSTRIA } & \multicolumn{2}{|c|}{ SERVIÇOS } \\
\hline & coeficientes & valores de $t$ & Coeficientes & valores de $i$ & coeficientes & valores de $t$ \\
\hline \multicolumn{7}{|l|}{ SEXO } \\
\hline Homem & 0,680 & $16,83^{*}$ & 0,835 & $12,90^{*}$ & 0,888 & $23,78^{*}$ \\
\hline Mulher & 0,000 & & & & 0,000 & \\
\hline \multicolumn{7}{|l|}{ IDADE } \\
\hline 10 a 14 anos & 0,000 & & 0,000 & & 0,000 & \\
\hline 15 a 17 anos & 0,216 & $2,41 *$ & 0,357 & $2,33^{*}$ & 0,376 & 2,38 \\
\hline 18 a 19 anos & 0,167 & 1,78 & 0,611 & $4,03^{*}$ & 0,644 & $4,01^{*}$ \\
\hline 20 a 24 anos & 0,462 & $5,76^{*}$ & 0,903 & $6,46^{*}$ & 0,945 & $6,48^{*}$ \\
\hline 25 a 29 anos & 0,568 & $7,04^{*}$ & 1,116 & $7,78^{*}$ & 1,303 & $8,93^{*}$ \\
\hline 30 a 39 anos & 0,721 & $9,30^{*}$ & 1,223 & $8,84^{*}$ & 1,599 & $11,16^{*}$ \\
\hline 40 a 49 anos & 0,765 & $9,67^{*}$ & 1,237 & $8,69^{*}$ & 1,837 & $12,67 *$ \\
\hline 50 a 59 anos & 0,746 & $9,20^{*}$ & 1,239 & $8,12^{*}$ & 1,751 & $11,60^{*}$ \\
\hline 60 anos ou mais & 0,889 & $10,61^{*}$ & 1,080 & $5,78 *$ & 1,752 & $10,12^{*}$ \\
\hline \multicolumn{7}{|l|}{ ESCOLARIDADE } \\
\hline sem instrução e menos de 1 ano & 0,000 & & 0,000 & & 0,000 & \\
\hline 1 ano & 0,061 & 1,05 & 0,084 & 0,87 & 0,227 & $2,12^{*}$ \\
\hline 2 anos & 0,141 & $2,67^{*}$ & 0,106 & 1,51 & 0,267 & $3,21 *$ \\
\hline 3 anos & 0,270 & $4,49^{*}$ & 0,070 & 1,03 & 0,319 & $4,34^{*}$ \\
\hline 4 anos & 0,370 & $5,99 *$ & 0,262 & $4,27 *$ & 0,489 & $8,22 *$ \\
\hline 5 anos ou mais & 0,520 & $4,47 *$ & 0,511 & $8,31^{\text {* }}$ & 1,229 & $23,74^{*}$ \\
\hline POSIÇÃO NA OCUPAÇÃO & & & & & & \\
\hline sem remuneração & $-0,479$ & $-1,94$ & (6) & (6) & (6) & (6) \\
\hline trabalhador agricola volante ${ }^{(2)}$ & $-0,058$ & $-0,84$ & (6) & (6) & (6) & (6) \\
\hline empregado ${ }^{(3)}$ & 0.000 & & 0,000 & & 0,000 & \\
\hline conta-própria ${ }^{(4)}$ & $-0,228$ & $-4,18^{*}$ & $-0,122$ & $-2,73^{*}$ & 0,131 & $2,98^{*}$ \\
\hline empregador $(9)$ & 0,625 & $6,28 *$ & 1,234 & $7,51^{*}$ & 1,351 & $8,45^{\text {}}$ \\
\hline
\end{tabular}

Fonte: IBGE. Dados individuais da Amostra de $0,8 \%$ do Censo Demográfico de 1980

Nota: Resultados do Procedure GLM/SAS.

Todos os coeficientes assinalados com $\left({ }^{*}\right)$ são estatisticamente significativos ao nivel de $5 \%$.

(1) As faixas foram alteradas devido ao pequeno número de observações nas faixas acima de 5 anos de estudo. (2) Trabalhador volante com intermediário e trabalhador volante sem intermediário. (3) Parceiro/empregado e empregado. (4) Parceiro/conta-própria e contaprópria. (5) Parceiro/empregador e empregador. (6) Estas categorias não foram registradas.

A tabela 14 revela os coeficientes de determinação e a contribuição marginal das variáveis sexo, idade, escolaridade e posição na ocupação para cada um dos três setores (agrícola, indústria e serviços). Os coeficientes de determinação são $21,7 \%$ para a regressão no setor agrícola, $41,6 \%$ no setor industrial e $50,7 \%$ no setor de serviços. 
Tabela 14. Número de observações, valores de $F$ e $R^{2}$ e contribuição marginal de cada fator para os modelos estimados para cada setor; Piauí- 1980.

\begin{tabular}{|c|c|c|c|}
\hline \multirow[t]{2}{*}{ ESTATISTICA } & \multicolumn{3}{|c|}{ SETORES } \\
\hline & Agrícola & Indústria & Servicos \\
\hline NÚMERO DE OBSERVAÇÕES & 3.172 & 850 & 2.142 \\
\hline$F^{(1)}$ & 48,65 & 37,12 & 136,45 \\
\hline COEFICIENTE DE DETERMINAÇÃO (\%) & 21,7 & 41,62 & 50,68 \\
\hline CONTRIBUIÇÃO MARGINAL ${ }^{(2)}$ & & & \\
\hline sexo & 32,3 & 28,0 & 25,9 \\
\hline idade & 31,9 & 37,0 & 26,2 \\
\hline escolaridade & 8,4 & 12,7 & 29,2 \\
\hline posição na ocupação & 14,2 & 11,5 & 3,5 \\
\hline
\end{tabular}

Fonte: IBGE. Dados individuais da Amostra de 0,8\% do Censo Demográfico de 1980.

Nota: Os setores foram classificados de acordo com a finalidade ou ramo do negócio, conforme o Censo. O setor agrícola agrupa: agricultura, silvicultura e pecuária, extração vegetal, pesca e piscicultura, extração mineral. Setor indústria agrupa: indústrias de transformação e construção. Setor serviços agrupa: serviços industriais de utilidade pública, comércio de mercadorias, Instituições de crédito, de seguros e de capitalização, comércio e administração de imóveis e valores imobiliários, transportes, comunicaçðes, serviços de alojamento e alimentação, serviços de reparação e conservação, serviços pessoais, serviços domiciliares, serviços de diversões, radiodifusão e televisão, serviços técnico-profissionais, serviços auxiliares das atividades econômicas, serviços comunitários e sociais (excluindo-se os serviços médicos, odontológicos, veterinários e de ensino), ensino, administração pública, defesa nacional e segurança pública, organizações internacionais e representações estrangeiras.

(1) Os valores de F são estatisticamente significativos ao nivel de $1 \%$. (2) Contribuição marginal do fator (SSII (fator) SSMODEL) conforme Procedure GLM/SAS, em percentual.

Os fatores que mais contribuiram para explicar as variações no rendimento das pessoas economicamente ativas na agricultura são o sexo, com $32,3 \%$, a idade, com $31,9 \%$, e a posição na ocupação com $14,2 \%$. Na indústria, a idade passa a ser o fator que mais explica, com $37,0 \%$, e o sexo, com $28,0 \%$. No setor de serviços, a escolaridade contribuiu com $29,2 \%$, a idade com $26,2 \%$ e o sexo com $25,9 \%$ na variação do rendimento.

Os números-índices, já descontados os efeitos dos demais fatores incluídos no modelo, são registrados na tabela 15 , indicando como o valor esperado do rendimento varia entre as diversas categorias de cada fator. Os resultados sugerem que o rendimento dos homens tende a ser 1,97 vezes maior que o das mulheres no setor agrícola, 2,3 vezes na indústria e 2,43 vezes nos serviços. 
Os números-índices comprovam que o rendimento das pessoas economicamente ativas cresce com a escolaridade. No caso da idade observa-se que a relação com a renda não é monotonicamente crescente; apenas na agricultura a estimativa da renda é máxima na faixa de 60 anos ou mais; no setor de serviços a estimativa da renda é máxima na faixa de 40 a 49 anos e na indústria há um patamar na faixa de 40 a 59 anos de idade

Tabela 15. Números-índices ${ }^{(1)}$ do nível do rendimento estimado para as categorias dos fatores considerados no modelo de regressão; Piauí- 1980.

\begin{tabular}{|c|c|c|c|}
\hline Fatores & Agrícola & Indústria & Servicos \\
\hline \multicolumn{4}{|l|}{ SEXO } \\
\hline Homem & 197 & 230 & 243 \\
\hline Mulher & 100 & 100 & 100 \\
\hline \multicolumn{4}{|l|}{ IDADE } \\
\hline 10 a 14 anos & 100 & 100 & 100 \\
\hline 15 a 17 anos & 124 & 143 & 146 \\
\hline 18 a 19 anos & 118 & 184 & 190 \\
\hline 20 a 24 anos & 159 & 247 & 257 \\
\hline 25 a 29 anos & 177 & 305 & 368 \\
\hline 30 a 39 anos & 206 & 340 & 494 \\
\hline 40 a 49 anos & 215 & 345 & 628 \\
\hline 50 a 59 anos & 211 & 345 & 576 \\
\hline 60 anos ou mais & 243 & 294 & 577 \\
\hline \multicolumn{4}{|l|}{ ESCOLARIDADE $^{(2)}$} \\
\hline sem instrução e menos de 1 ano & 100 & 100 & 100 \\
\hline 1 ano & 106 & 108 & 126 \\
\hline 2 anos & 115 & 111 & 131 \\
\hline 3 anos & 131 & 107 & 138 \\
\hline 4 anos & 145 & 130 & 163 \\
\hline 5 anos ou mais & 168 & 167 & 342 \\
\hline \multicolumn{4}{|l|}{ POSIÇÃO NA OCUPAÇÃO } \\
\hline sem remuneração & 62 & (7) & (7) \\
\hline trabalhador agricola volante ${ }^{(3)}$ & 94 & (7) & (7) \\
\hline empregado ${ }^{(4)}$ & 100 & 100 & 100 \\
\hline conta-própria & 80 & 88 & 114 \\
\hline empregador ${ }^{(6)}$ & 187 & 344 & 386 \\
\hline
\end{tabular}

Fonte: Dados individuais das PNAD de 1992, 1993 e 1995.

(1) Se $\beta$ é um coeficiente estimado da equação de rendimentos, o número-índice é $100 \exp (\beta)$. (2) As faixas foram alteradas devido ao pequeno número de observações nas faixas acima de 5 anos de estudo. (3) Trabalhador agrícola volante com intermediário e trabalhador agricola volante sem intermediário. (4) Parceiro/empregado e empregado. (5) Parceiro/conta-própria e conta-própria. (6) Parceiro/empregador e empregador. (7) Estas categorias não foram registradas.

Verifica-se que as categorias sem remuneração, trabalhador agrícola volante e conta-própria tendem a ganhar $38 \%, 6,0 \%$ e $20,0 \%$, respectivamente, menos do que o empregado no setor agrícola. $\mathrm{Na}$ indústria, a categoria conta-própria ganha $12 \%$ menos 
que o empregado e, no setor de serviços, o rendimento dessa categoria é 1,14 vezes maior que do empregado. Nota-se que um empregador tende a ganhar 1,87 vezes mais que o empregado no setor agrícola. Já no setor industrial essa diferença aumenta para 3,44 vezes e nos serviços para 3,86 vezes.

Esses resultados estão compatíveis, em geral, aos obtidos por Hoffmann (1996), que utilizou as mesmas informações para o Brasil e Macrorregiões. Entretanto, pode-se inferir que as especificidades do Piauí são: na agricultura, o principal condicionante do rendimento é o sexo, seguido por idade e posição na ocupação; na indústria, a idade, seguida do sexo e, no setor serviços, a escolaridade, seguida por idade e sexo. No Brasil, o condicionante mais importante no setor agrícola é a escolaridade, seguida por idade, enquanto, nos setores industrial e serviços, é a idade, seguido por posição na ocupação, ficando a escolaridade em terceiro lugar. 


\section{DESIGUALdADE E POBREZA NO PIAUÍ: ANOS 90}

Neste capitulo, procede-se à análise empírica dos dados publicados das PNAD de 1984 a 1990, 1992, 1993, 1995 e 1996. Mostra-se a evolução das medidas de desigualdade e pobreza e testam-se as relações funcionais entre pobreza, desigualdade e renda média, entre pobreza, inflação e salário mínimo e entre desigualdade, inflação e salário mínimo.

O estudo da desigualdade e pobreza nos anos 90 será realizado, mais detalhadamente, através dos dados individuais das PNAD de 1992, 1993 e 1995. Para isso, caracteriza-se a PEA com rendimento, segundo classes de renda em salários mínimos, considerando o sexo, situação do domicilio, anos de estudo e idade. Verificam-se as formas de inserção da PEA com rendimento no mercado de trabalho, segundo o setor de atividade do trabalho principal (agrícola ou não-agrícola) e identificam-se os fatores associados à desigualdade da distribuição, com o auxílio do Procedure GLM do SAS (procedimento do Statiscal Analysis Software-SAS- para estimação de modelos lineares generalizados).

Hoffmann (1996) observa que, no Brasil, a desigualdade em 1995 é menor que em 1993, mas substancialmente maior que a desigualdade em 1992 e comparável à observada na primeira metade da década de 80 . E destaca o fato de a desigualdade ser 
relativamente baixa em 1992 e grande a elevação do rendimento médio de 1993 a 1995, acompanhada da redução das medidas de pobreza absoluta.

A vasta literatura sobre a pobreza no Brasil identificou na região Nordeste a prevalência de um foco de pobreza rural. O Estado do Piauí é representativo desta pobreza nordestina e qualificado como de baixo desenvolvimento humano. Examina-seo grau de pobreza absoluta nos anos 90 , através das medidas de pobreza e os fatores que condicionam este fenômeno como insuficiência de renda.

\subsection{Evolução da distribuição da renda e pobreza no período de 1984 a 1996}

A tabela 16 mostra a evolução das medidas de tendência central e desigualdade calculadas a partir destas informações sobre rendimento geral das pessoas economicamente ativas, publicadas pelo IBGE (PNAD) para o periodo de 1984 a 1990, 1992, 1993, 1995 e 1996.

No Piauí, em 1984, os $10 \%$ mais ricos detinham $51,6 \%$ da renda e os $5 \%$ mais ricos, 40,9\%, sendo a renda média de 1,02 SM. Em 1985, a desigualdade e pobreza aumentam e os $10 \%$ mais ricos passam a concentrar $55,2 \%$ da renda e os $5 \%$ mais ricos $43,5 \%$, ocorrendo um aumento de $5,7 \%$ na renda média, que passou a ser $1,07 \mathrm{SM}$. O ano de 1986 foi o do Plano Cruzado, que acarretou uma redução da desigualdade e pobreza em todo o Brasil. No Piauí, a renda média cresceu para $1,57 \mathrm{SM}$, com os $50 \%$ mais pobres participando com 13,2\% na renda, voltando a decrescer para 9,9\% em 1987 . 
Tabela 16. Medidas de tendência central e desigualdade para a população economicamente ativa com rendimento; Piauí - 1984 a 1990, 1992, 1993, 1995 e 1996.

\begin{tabular}{|c|c|c|c|c|c|c|c|}
\hline \multirow[b]{2}{*}{ Anos } & \multirow[b]{2}{*}{$\begin{array}{l}\text { Renda } \\
\text { média }\end{array}$} & \multirow[b]{2}{*}{ Mediana $^{(1)}$} & \multirow[b]{2}{*}{$\begin{array}{l}\text { Índice de } \\
\text { Gini }(G)\end{array}$} & \multirow[b]{2}{*}{$\begin{array}{l}\text { Indice de } \\
\text { Theil }(\mathrm{T})\end{array}$} & \multicolumn{3}{|c|}{$\begin{array}{c}\text { Porcentagem da renda apropriada } \\
\text { pelos }\end{array}$} \\
\hline & & & & & $\begin{array}{l}50 \% \text { mais } \\
\text { pobres }\end{array}$ & $\begin{array}{l}10 \% \text { mais } \\
\text { ricos }\end{array}$ & $\begin{array}{l}5 \% \text { mais } \\
\text { ricos }\end{array}$ \\
\hline 1984 & 1,02 & 0,525 & 0,598 & 0,586 & 14,2 & 51,6 & 40,9 \\
\hline 1985 & 1,07 & 0,486 & 0,654 & 0,648 & 10,6 & 55,2 & 43,5 \\
\hline 1986 & 1,57 & 0,819 & 0,602 & 0,552 & 13,2 & 49,7 & 37,3 \\
\hline 1987 & 1,23 & 0,530 & 0,655 & 0,600 & 9,9 & 54,1 & 40,7 \\
\hline 1988 & 1,00 & 0,429 & 0,662 & 0,629 & 10,3 & 56,6 & 44,0 \\
\hline 1989 & 1,30 & 0,589 & 0,668 & 0,671 & 10,3 & 57,6 & 46,4 \\
\hline 1990 & 1,16 & 0,486 & 0,652 & 0,622 & 10,9 & 55,2 & 42,5 \\
\hline 1992 & 1,10 & 0,642 & 0,610 & 0,555 & 11,9 & 49,5 & 37,8 \\
\hline 1993 & 1,23 & 0,659 & 0,613 & 0,593 & 13,0 & 50,8 & 39,1 \\
\hline 1995 & 1,48 & 0,690 & 0,580 & 0,524 & 14,7 & 48,1 & 35,8 \\
\hline 1996 & 1,50 & 0,712 & 0,567 & 0,474 & 14,8 & 46,1 & 31,7 \\
\hline
\end{tabular}

Fonte: IBGE. Dados básicos das. PNAD de 1984 a 1996.

(1) em SM de ago./80.

No ano de 1987, a renda média no Estado do Piauí decresceu em 21,8\%, uma porcentagem maior que a observada para a média da região nordestina, que foi de $20 \%$. Em 1988, a renda média decresceu, novamente, tendo o menor nível do período de 1984-1996, com os 50\% mais pobres participando com 10,3\% na renda. A renda média volta a se elevar em 1989 (1,3 SM), mas o Piauí continua com a menor renda média 
entre os estados nordestinos, apesar de ocorrer uma diminuição das medidas de desigualdade.

A figura 3 descreve a evolução das rendas média e mediana no período de 1984 a 1996 no Piauí, considerando a PEA com rendimento. As rendas média e mediana oscilam conforme o crescimento e decréscimo do PIB per capita no Brasil, apesar da pequena participação do PIB piauiense no PIB brasileiro, em torno de $0,5 \%$ no período de 1985 a 1995.

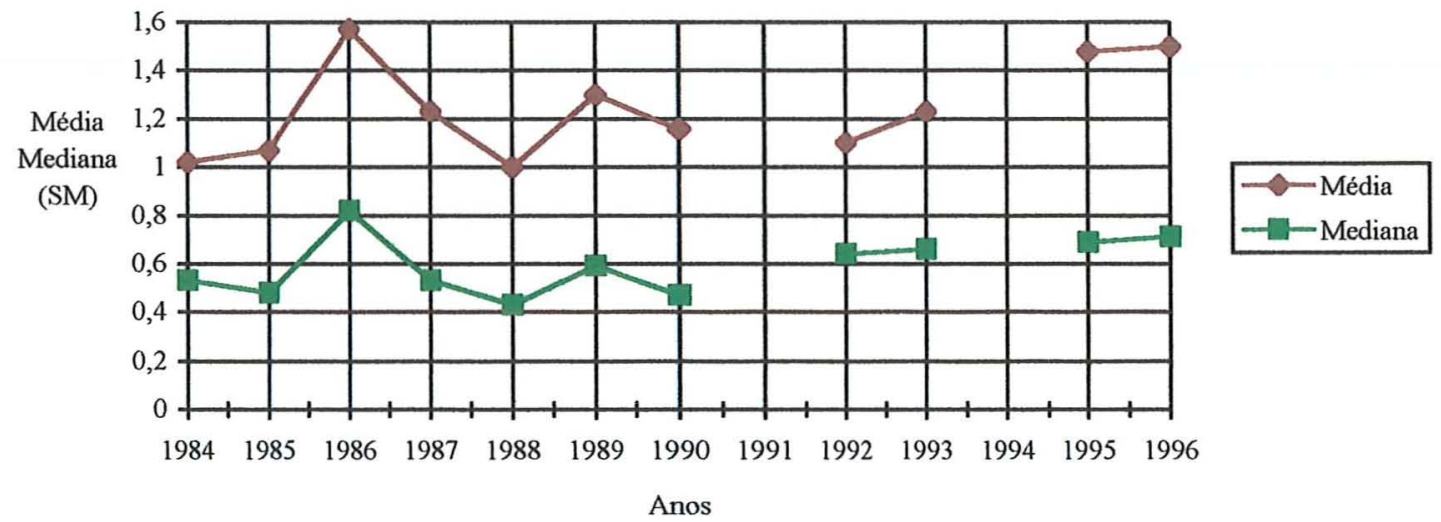

Figura 3. Renda média e mediana (em SM) para pessoas economicamente ativas com rendimento; Piauí - 1984 a 1990, 1992, 1993,1995 e 1996.

A tabela 17 mostra a variação percentual do produto interno bruto (PIB) a custo de fatores para a Região Nordeste e Estados nos períodos de 1980-1985, 1985-1990 e 1990-1995.

Verifica-se que no quinqüênio 1980-85 o PIB a custo de fatores no Piauí apresenta variação abaixo da Região Nordeste, refletindo os períodos de aceleração e desaceleração da economia brasileira. No período de 1985 a 1990 a taxa de variação observada do PIB foi de $26,3 \%$ acima do Nordeste e Brasil, observando-se que os 
estados menos desenvolvidos apresentam uma menor oscilação do que nos estados que concentram a atividade econômica regional, devido aos efeitos dos ciclos econômicos serem mais acentuados nas áreas mais voltadas para o mercado. Já no período de 199095 ocorre uma diminuição na variação do PIB piauiense para 7,4\% abaixo da nordestina, que foi de $11,0 \%$, e da brasileira, de $14,3 \%$.

Tabela 17. Variação percentual do PIB do Brasil, da Região Nordeste e dos Estados nos quinquênios 1980-85, 1985-90 e 1990-95.

\begin{tabular}{c|c|c|c}
\hline & & Quinquênios & \\
\cline { 2 - 4 } NORDESTE E ESTADOS & $1980-85$ & $1985-90$ & $1990-95$ \\
\hline NORDESTE & 21,1 & 11,5 & 11,0 \\
Maranhão & 27,3 & 20,6 & 7,3 \\
PIAUÍ & $\mathbf{2 0 , 4}$ & $\mathbf{2 6 , 3}$ & $\mathbf{7 , 4}$ \\
Ceará & 16,7 & 9,2 & 26,6 \\
Rio Grande do Norte & 46,9 & 11,1 & 18,1 \\
Paraiba & 12,1 & 24,4 & 8,6 \\
Pernambuco & 1,1 & 16,8 & 11,2 \\
Alagoas & 14,8 & 30,2 & 3,7 \\
Sergipe & 83,8 & 29,8 & 0,2 \\
Bahia & 25,8 & 0,2 & 8,8 \\
BRASIL & 6,5 & 9,7 & 14,3 \\
\hline
\end{tabular}

Fonte: Dados do PIB a custo de fatores dos Estados, Região Nordeste e Brasil (em US\$1.000,00 constantes de 1995) extraídos de Azzoni (1997, p.380-383).

Com relação ao PIB per capita, o Estado do Piauí acompanha a tendência para Brasil e Região Nordeste no período de 1985 a 1995, conforme registrado na figura 4. Entretanto, as rendas médias no Piauí e Nordeste estão sempre abaixo da média brasileira (figura 5). 


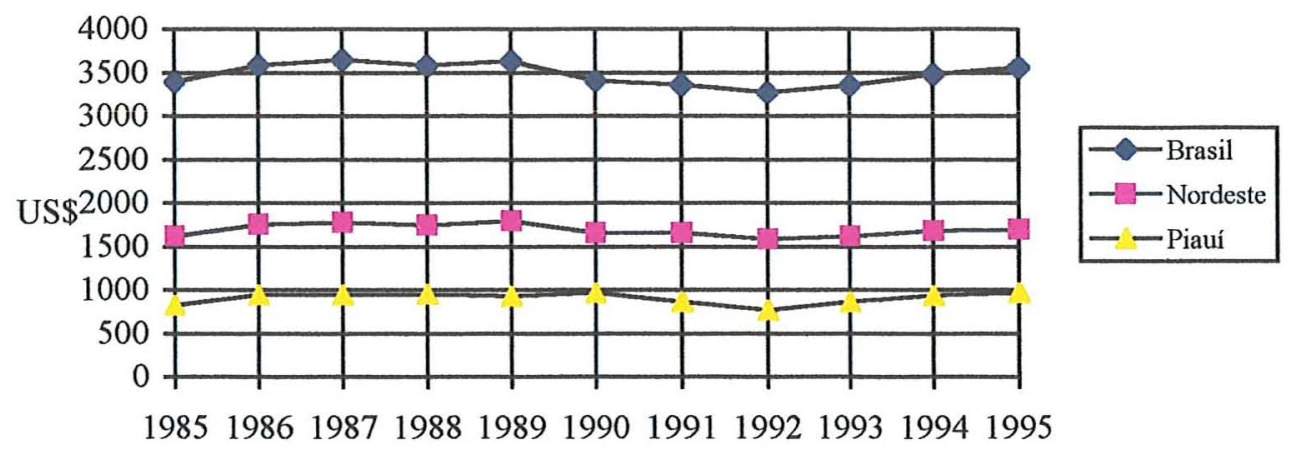

Anos

Figura 4. Evolução do produto interno bruto per capita (US\$ constantes em 1995); Brasil, Nordeste e Piauí -1985 a 1995.

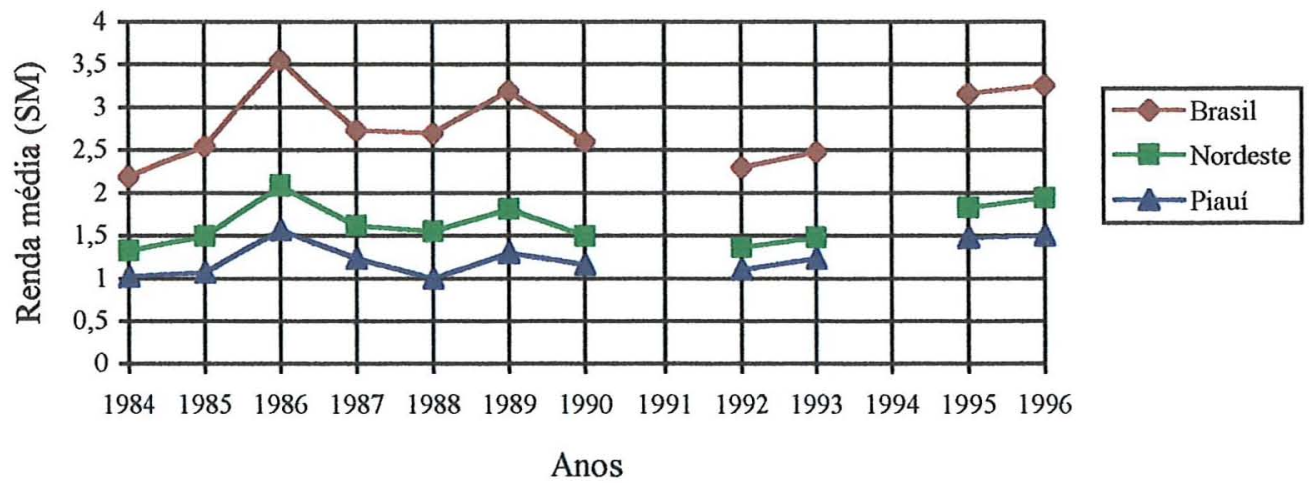

Figura 5. Renda média (em SM) para pessoas economicamente ativas com rendimento; Brasil, Nordeste e Piauí; 1984 a 1990, 1992, 1993, 1995 e 1996.

Considerando o comportamento do rendimento médio e das medidas de desigualdade no Nordeste e Piauí após 1992, verifica-se que a desigualdade se torna relativamente menor no Piauí e o rendimento médio no estado cresce mais lentamente do que no Nordeste, conforme tabela 18. 
Tabela 18. Crescimento percentual do rendimento médio; Brasil, Nordeste e Piauí nos períodos de 1992 a 1996, 1995 a 1996 e 1993 a 1995.

\begin{tabular}{c|c|c|c}
\hline \multirow{2}{*}{ Unidades } & \multicolumn{3}{|c}{ Periodos } \\
\cline { 2 - 4 } & 1993 a 1995 & 1992 a 1996 & 1995 a 1996 \\
\hline Piaui & 36,4 & 1,4 & 20,3 \\
Nordeste & 42,4 & 2,8 & 28,3 \\
Brasil & 42,6 & 6,0 & 23,6 \\
\hline
\end{tabular}

Fonte: IBGE. Dados básicos das PNAD de 1992 a 1996.

A partir de 1993, ocorre uma contínua diminuição da desigualdade, conforme os índices de Gini e Theil. Isso deve-se, em parte, à redução do ritmo inflacionário. A variação da inflação mensal, considerando o mês de referência da PNAD (setembro) e o mês anterior, passou de 35,6\% em 1993 para 0,02\% em 1996, possibilitando uma recomposição do poder de compra da PEA.

Essa recomposição do poder de compra da PEA foi uma tendência geral das Unidades da Federação, conforme constatado por Hoffmann (1992, p.113), para quem

"A clara associação positiva entre a taxa de inflação e as medidas de desigualdade da distribuição da renda entre as pessoas economicamente ativas mostra que a redução da inflação pode ser defendida não apenas visando maior estabilidade e eficiência do sistema econômico, mas também visando diminuir a desigualdade da distribuição da renda".

A tabela 19 apresenta a evolução da pobreza absoluta. Verifica-se que a proporção de pobres $(H)$ decresce de 1984 a 1986 e de 1990 a 1996, captando a extensão da pobreza no Estado do Piauí. 
Tabela 19. Medidas de pobreza ${ }^{(1)}$ para a população economicamente ativa com rendimento; Piauí - 1984 a 1996.

\begin{tabular}{c|c|c|c|c|c}
\hline ANOS & $\begin{array}{c}\text { Proporção de } \\
\text { pobres } \\
(\mathrm{H})\end{array}$ & $\begin{array}{c}\text { Razão de } \\
\text { insuficiência } \\
(\mathrm{I})\end{array}$ & $\begin{array}{c}\text { Indice de } \\
\text { pobreza de } \\
\text { Sen (P) }\end{array}$ & $\mathrm{r}(\%)^{(2)}$ & $\begin{array}{c}\text { Indice de } \\
\text { FGT }\end{array}$ \\
\hline 1984 & 0,789 & 0,552 & 0,548 & 42,9 & 0,290 \\
1985 & 0,768 & 0,609 & 0,582 & 43,6 & 0,337 \\
1986 & 0,614 & 0,498 & 0,403 & 19,5 & 0,199 \\
1987 & 0,720 & 0,610 & 0,546 & 35,7 & 0,317 \\
1988 & 0,773 & 0,640 & 0,609 & 49,5 & 0,371 \\
1989 & 0,730 & 0,576 & 0,536 & 32,3 & 0,298 \\
1990 & 0,749 & 0,604 & 0,557 & 39,1 & 0,319 \\
1992 & 0,713 & 0,577 & 0,530 & 37,5 & 0,298 \\
1993 & 0,706 & 0,547 & 0,498 & 31,4 & 0,265 \\
1995 & 0,622 & 0,487 & 0,390 & 20,4 & 0,186 \\
1996 & 0,618 & 0,478 & 0,381 & 19,7 & 0,178 \\
\hline
\end{tabular}

Fonte: IBGE. Dados básicos das PNAD de 1984 a 1996.

(1) Linha de pobreza igual a $1 \mathrm{SM}$ ago./80, conforme INPC. (2) Insuficiência da renda como porcentagem da renda total.

A razão de insuficieiencia de renda (I) é decrescente nos anos 90, atingindo 0,478 em 1996. Essa medida é sensivel à intensidade da pobreza, isto é, seu valor é afetado pela redução da renda de um pobre, mas é insensível ao número de pobres.

O índice de Sen é uma medida de pobreza que leva em consideração tanto a extensão quanto a intensidade da pobreza, bem como a desigualdade da distribuição da renda entre os pobres. Ele varia de zero a 1 e, tanto mais próximo de 1, maior o grau de pobreza absoluta. Esse índice tem uma variação de -31,6\% no período de 1990 a 1996.

Outra medida do grau de pobreza absoluta é o índice de Foster, Greer e Thorbecke (FGT) que, da mesma maneira que o de Sen, varia de zero a 1, e mostra também o decréscimo da pobreza piauiense nos anos 90 . 
Esse decrescente grau de pobreza absoluta no Piauí decorre, em parte, do processo de urbanização ${ }^{26} \mathrm{e}$ da redução do ritmo inflacionário brasileiro.

A taxa de urbanização no Piauí foi de $41,98 \%$ em 1980 e passou para $52,95 \%$ em 1991, conforme consta em IBGE (1995), confirmando a tendência iniciada no final da década de 80 , quando a população urbana ultrapassou a rural. Cabe destacar que a capital, Teresina, concentrava 23,21\% do efetivo populacional do estado em 1991.

Em 1996, a proporção da PEA com rendimento na área urbana no Piauí foi de $66,2 \%$, enquanto em 1995 foi de $60,3 \%$, ocorrendo uma variação de $9,8 \%$ em apenas um ano.

Para o IBGE (1995), esse incremento na população urbana foi basicamente conseqüência de três fatores: o próprio crescimento vegetativo nas área urbanas, a migração com destino urbano, sobretudo dentro do próprio estado, e a incorporação de áreas que, por ocasião do Censo de 1980, eram consideradas rurais.

Na figura 6, visualiza-se o comportamento do Índice de Gini e, na figura 7,o Índice de Sen, conjuntamente para o Piauí, Região Nordeste e Brasil. Observa-se que a desigualdade é crescente até 1989, exceção de 1986 (Plano Cruzado), voltando a crescer de 1992 para 1993, decrescendo em 1995 e 1996. A pobreza decresce de forma contínua nos anos 90, mas o Índice de Sen no Piauí é sempre superior ao do Nordeste e Brasil.

\footnotetext{
${ }^{26}$ Kageyama e Rehder (1993) mostraram a influência positiva da produtividade agrícola e urbanização sobre o nivel de bem-estar rural.
} 


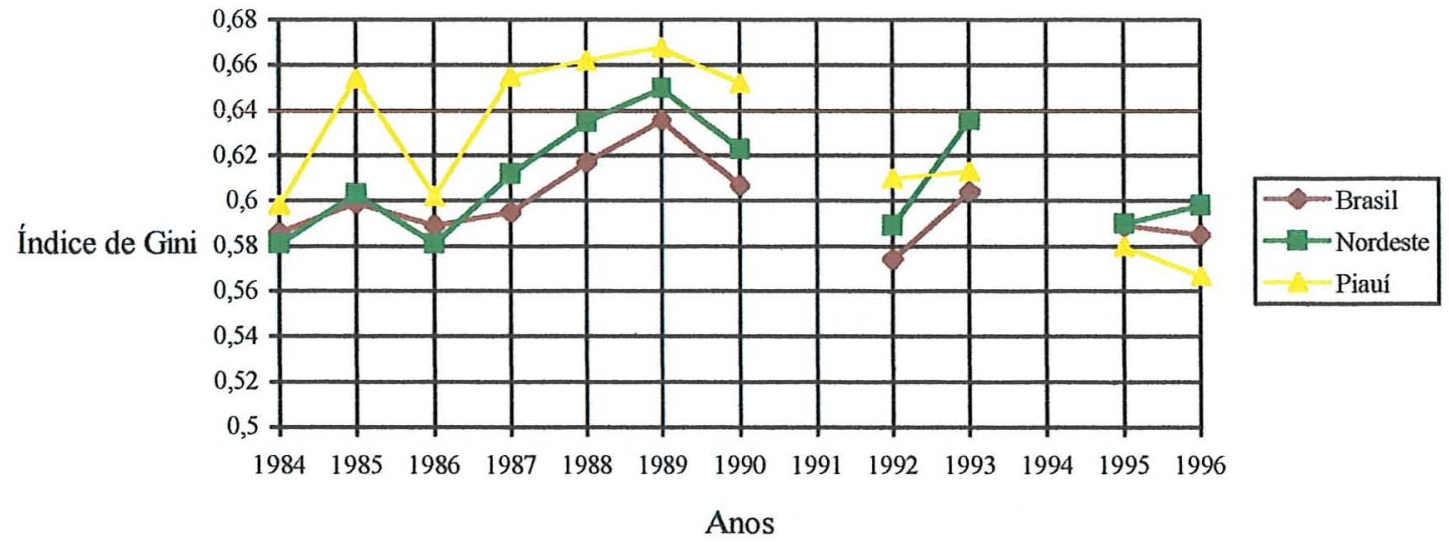

Figura 6. Índice de Gini para pessoas economicamente ativas com rendimento. Brasil, Nordeste e Piauí - 1984 a 1990, 1992, 1993, 1995 e 1996.

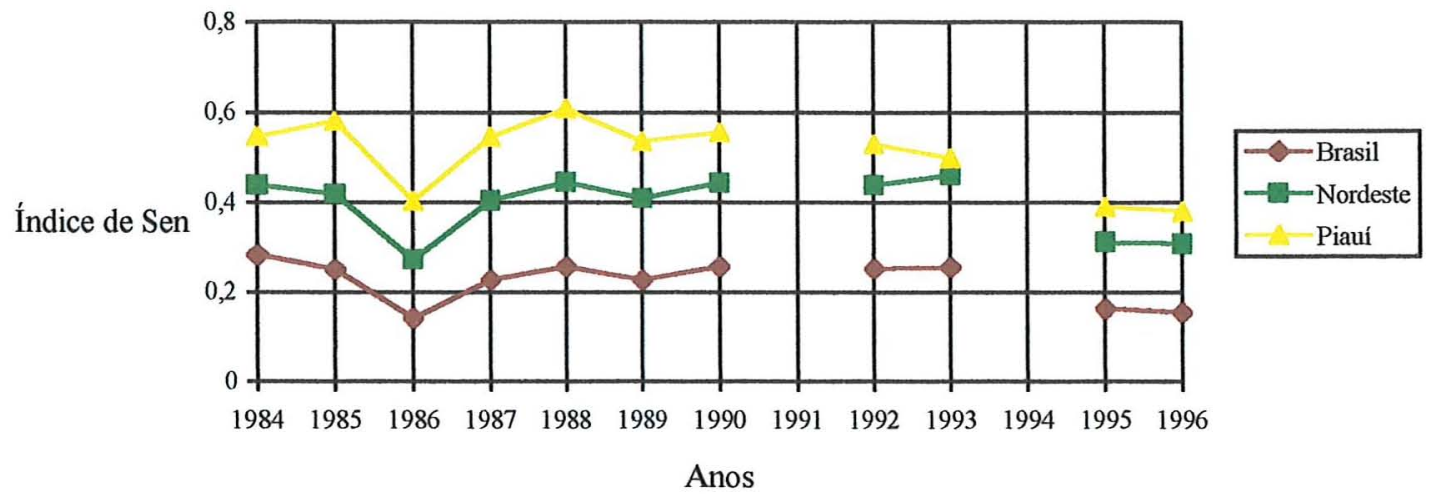

Figura 7. Índice de Sen para pessoas economicamente ativas com rendimento; Brasil, Nordeste e Piauí - 1984 a 1990, 1992, 1993, 1995 e 1996.

A desigualdade da distribuição da renda se manifesta de forma mais intensa no Piauí do que no Nordeste no período de 1984 a 1990. A partir de 1992, a desigualdade da distribuição da renda diminui no Piauí e chega a surpreender quando, em 1996, atinge um índice de Gini de 0,567 , menor que o do Brasil $(0,585)$ e do Nordeste $(0,598)$, 
indicando uma tendência declinante nos índices de desigualdade em relação a 1992 $(0,610)$ e $1993(0,613)$.

No Piauí, no período de 1984 a 1990, 1992, 1993, 1995 e 1996, o comportamento da renda média, mediana, desigualdade e pobreza acompanha a tendência geral do Nordeste e do Brasil.

A especificidade do Estado do Piauí em relação ao Nordeste está no decréscimo de 5,5\% na desigualdade da distribuição da renda no período de 1984 a 1996, conjuntamente com o crescimento de $47,1 \%$ na renda média e diminuição de $28,8 \%$ na proporção de pobres, enquanto na Região Nordeste ocorre elevação de $2,9 \%$ na desigualdade e $47,0 \%$ na renda média e decréscimo de $30,1 \%$ na pobreza.

É interessante salientar que a proporção de pobres $(0,618)$ para o Piauí em 1996 é ainda maior que a do Nordeste $(0,548)$ e a do Brasil $(0,307)$, confirmando que a insuficiência de renda das pessoas economicamente ativas é o problema crucial do Estado.

No Piauí, necessita-se que $19,7 \%$ da renda total seja redistribuída para eliminar a pobreza absoluta em 1996, enquanto no Nordeste é preciso apenas $12,2 \%$ e no Brasil $3,6 \%$. Isso sinaliza para as entidades governamentais e não-governamentais que é preciso gerar mecanismos compensatórios de renda no Piauí, a partir das suas características demográficas e produtivas, com o intuito de reverter essa situação.

O grau de pobreza no Estado pode ser também avaliado pela evolução da proporção de domicílios particulares permanentes com abastecimento d'água, esgotamento sanitário, destino do lixo, iluminação elétrica e telefone, no período de 1984 a 1996 (figuras 8 e 9). Verifica-se uma nítida tendência de aumento desses indicadores, tanto no domicílio urbano quanto no rural. 


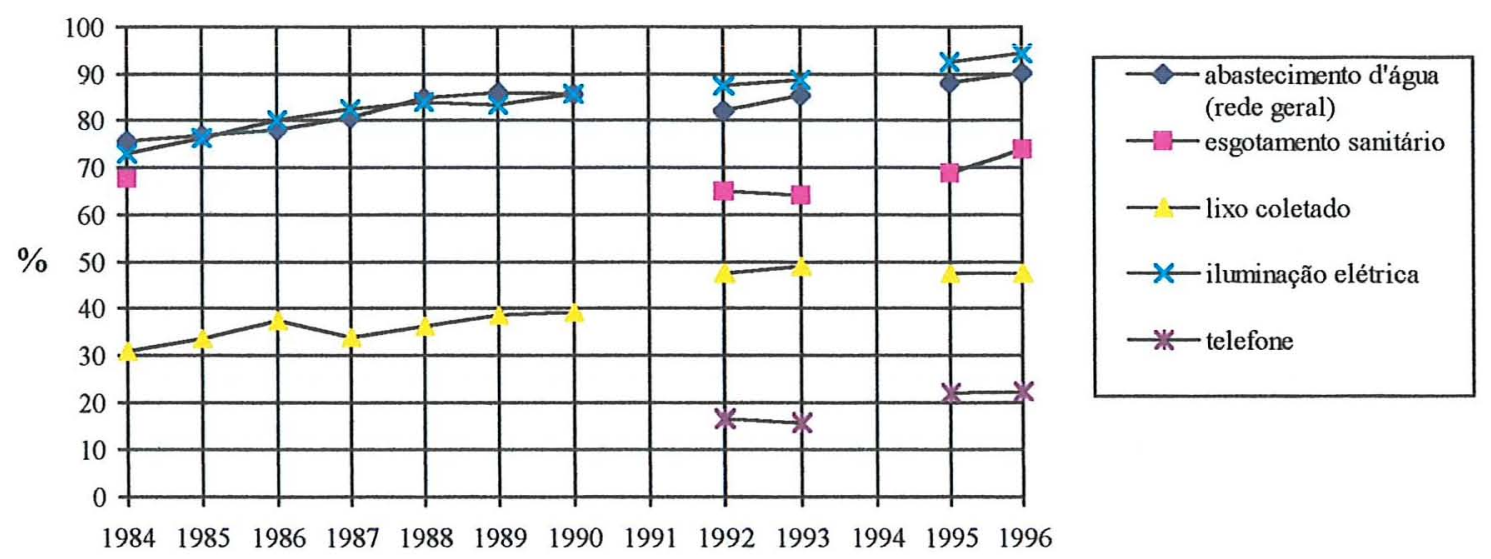

Anos

Figura 8. Proporção de domicílios particulares permanentes, segundo algumas características do domicílio urbano. Piauí - 1984 a 1996.

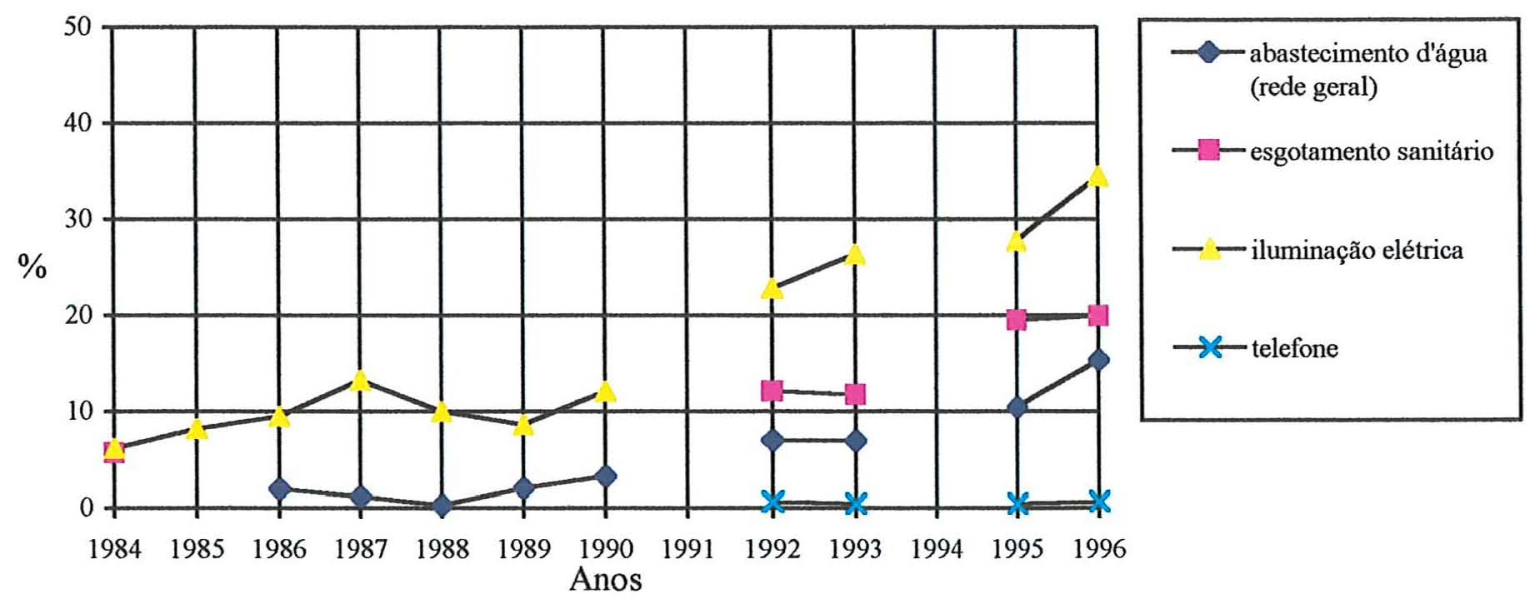

Figura 9. Proporção de domicílios particulares permanentes, segundo algumas características do domicílio rural. Piauí - 1984 a 1996.

Em 1996, apenas uma pequena proporção de domicílios rurais possuíam infraestrutura básica. Observa-se que os domicílios rurais não tinham abastecimento d'água 
via rede geral $(84,7 \%)$, esgotamento sanitário $(80,0 \%)$, iluminação elétrica $(65,6 \%)$ e telefone $(99,4 \%)$, indicando a ausência de investimentos públicos nesse setor.

As figuras 10 e 11 mostram a proporção de domicílios urbanos e rurais, respectivamente, que possuem alguns bens duráveis. A importância desses indicadores está no fato de não dependerem de um deflator e refletirem algum poder de compra das pessoas residentes nos domicílios. Eles apontam a mesma tendência de diminuição do grau de pobreza absoluta, esboçada pelas medidas de pobreza calculadas com o uso do INPC como deflator.

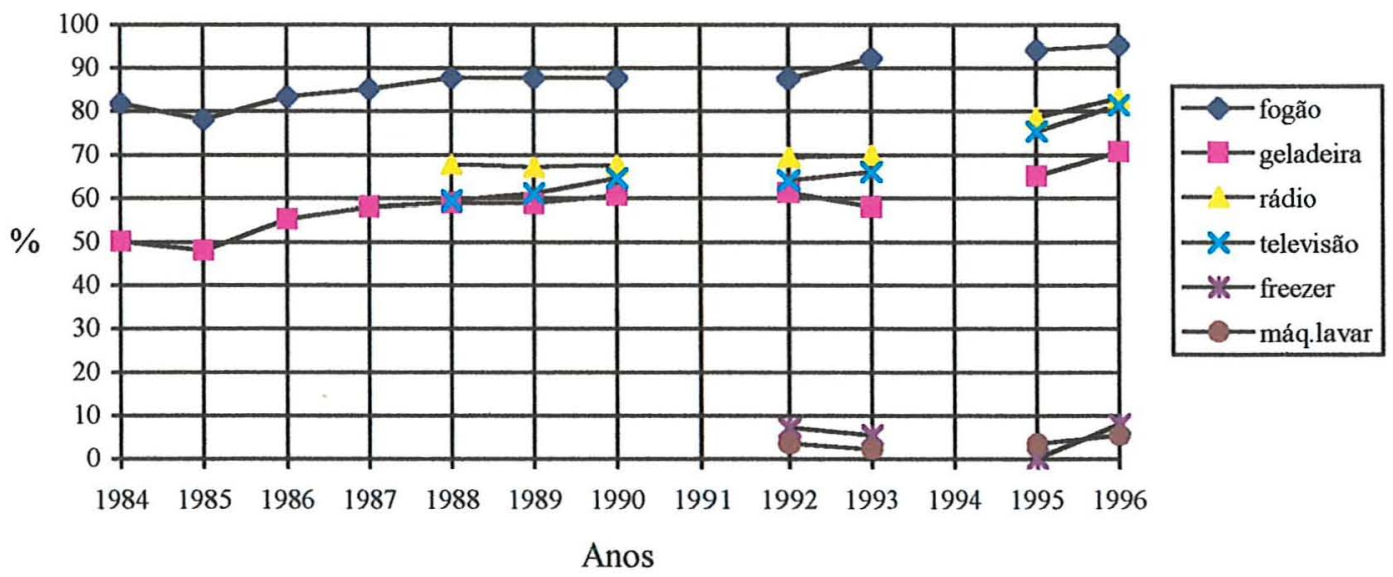

Figura 10. Proporção de domicílios particulares permanentes, segundo alguns bens duráveis existentes no domicílio urbano; Piauí - 1984 a 1996. 


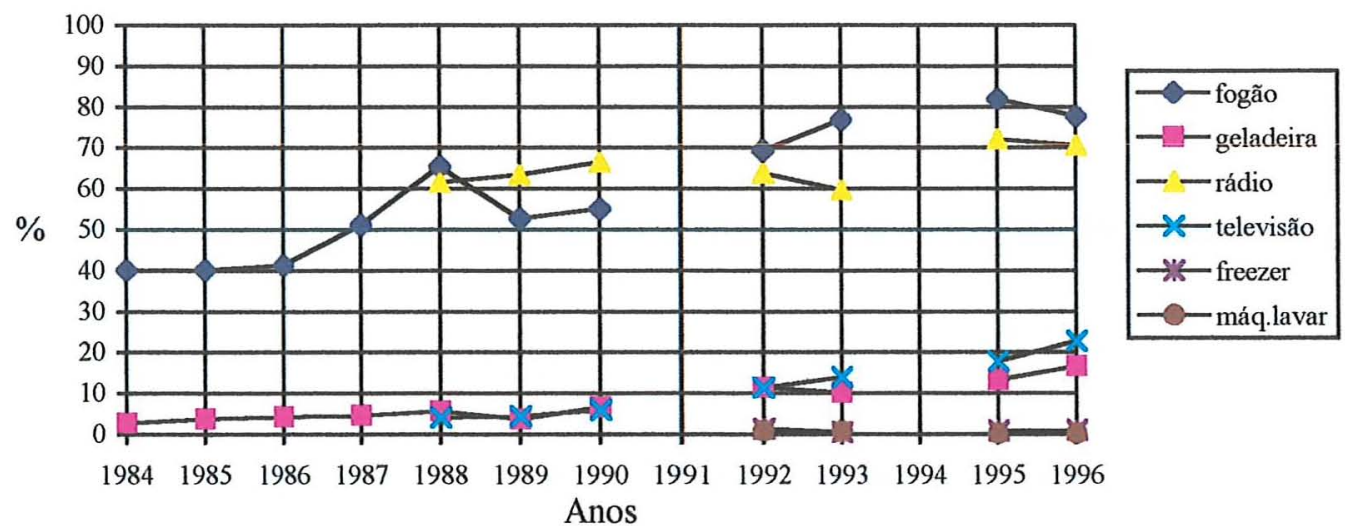

Figura 11. Proporção de domicílios particulares permanentes, segundo alguns bens duráveis existentes no domicílio rural; Piauí - 1984 a 1996.

Observa-se que, no geral, houve um aumento dos bens duráveis nos domicílios, mas a proporção de domicílios urbanos com bens duráveis é bastante superior à de domicílios rurais com bens duráveis. Entretanto, o crescimento percentual de bens duráveis nos domicílios rurais é maior que nos domicílios urbanos.

Os domicílios em área rural apresentam, nos anos 90, um crescimento percentual de $45,6 \%$ para geladeira e de $100 \%$ para televisão, considerando o período de 1992 a 1996. Nos domicílios urbanos, o crescimento é de $15,5 \%$ para geladeira e $27,1 \%$ para televisão, de 1992 a 1996. Esses dados revelam um aumento do poder de compra das pessoas no Piauí e também o decréscimo da pobreza absoluta no Piauí.

\subsubsection{Relação funcional entre pobreza, desigualdade e renda média}

Hoffmann (1995), em estudo sobre a relação entre pobreza absoluta, renda média e desigualdade da distribuição da renda, discute as possíveis formas para relações funcionais entre essas variáveis, partindo do princípio de que, fixada a linha de pobreza, uma medida de pobreza absoluta não é, necessariamente, uma função decrescente da 
renda média e uma função crescente da desigualdade da renda, porque alterações $\operatorname{artificiais~}^{27}$ em uma dada distribuição da renda podem alterar a desigualdade e a média sem afetar as medidas de pobreza absoluta.

Entretanto, fixado o tipo de distribuição, como a log-normal, as medidas de pobreza absoluta (proporção de pobres ou os índices de pobreza de Sen e Foster, Greer e Thorbecke) passam a ser funções decrescentes do rendimento médio $(\mu)$ e crescentes da desigualdade da distribuição.

Hoffmann (1995, p.355) afirma que

“...há uma certa regularidade na distribuição da renda no Brasil, nas regiões e ao longo do tempo. Apesar das mudanças substanciais na média e na desigualdade, há certa estabilidade na forma da distribuição, que permanece semelhante a uma log-normal. É essa estabilidade na forma da distribuição que faz com que haja uma relação funcional quase exata entre uma medida de pobreza absoluta (P ou $\varphi$ ), o rendimento médio e a desigualdade da distribuição. Os resultados sugerem que a distribuição log-normal constitui uma boa primeira aproximação da forma da distribuição de renda no Brasil, tendo em vista analisar como as medidas de pobreza absoluta variam em função da média $e$ da desigualdade da distribuição".

A relação funcional entre pobreza, desigualdade e renda média é estabelecida através de uma equação de regressão estimada pelo método de mínimos quadrados ponderados em que o fator de ponderação é a freqüência de pessoas, sendo $P$ o índice de Sen para uma linha de pobreza de $1 \mathrm{SM}$ de ago./80, $\mu$ a renda média da população economicamente ativa com rendimento, e $G$ o índice de Gini. Utilizando os valores dessas variáveis, constantes das tabelas 16 e 19, foram ajustados vários modelos, que

\footnotetext{
${ }^{27}$ "Transferências regressivas de renda entre pessoas que estão acima da linha de pobreza, de maneira que a pessoa cuja renda é reduzida não se torne pobre, farão com que aumente a desigualdade sem afetar aquelas medidas de pobreza absoluta e a renda média". Hoffmann (1995, p.1).
} 
estão em apêndice. O modelo que obteve ajustamento razoável é expresso pela seguinte equação de regressão (valores de $t$ entre parênteses),

$$
P=\underset{(-30,585)}{0,206} \underset{\mathbf{( 2 0 , 9 5 6 )}}{0,269}
$$

com $R^{2}$ igual a 0,998 , indicando que $99,8 \%$ da soma de quadrados total é "explicado" pela regressão linear ajustada.

O nível de pobreza absoluto é função decrescente da renda média $(\mu)$ e função crescente da desigualdade $(G)$. Para o coeficiente de $\mu$, tem-se $t$ igual a $\mathbf{- 3 0 , 5 8 5}$ e a probabilidade de $(|t|>30,585)$ igual a $0,01 \%$. Como essa probabilidade é menor do que $1 \%$, conclui-se que $t$ igual a $-30,585$ é significativo ao nível de $1 \%$. Já para o coeficiente de $G$, tem-se $t$ igual a $\mathbf{2 0 , 9 5 6}$ e a probabilidade $|t|>20,956$ igual a $0,01 \%$, sendo significativo ao nível de $1 \%$.

Os modelos estimados (em apêndice) sinalizam que o nível de pobreza absoluta no Piauí, de 1984 a 1996, está associado mais com as variações na renda média do que com as mudanças no grau da desigualdade da distribuição da renda. A regressão de $P$ contra $\mu$ e $\mu^{2}$ tem $R^{2}$ igual a $\mathbf{0 , 8 7 7}$ e na regressão de $P$ contra $G$ e $G^{2}$ o $R^{2}$ é igual a 0,756 .

\subsubsection{Relação funcional entre pobreza, desigualdade e inflação}

A relação da desigualdade da distribuição da renda com a intensidade da inflação foi estabelecida para o Brasil nos estudos de Hoffmann (1992), Cardoso (1993), Cardoso, Barros e Urani (1993) e Corrêa (1995), considerando, em geral, o período de 1981 a 1990. Os resultados apontaram um efeito positivo da inflação na desigualdade da distribuição da renda. 
A seguir será analisada, para o Piauí, a relação funcional entre pobreza, desigualdade, renda média e inflação, considerando as pessoas economicamente ativas com rendimento, no período de 1984-1996. Os dados utilizados encontram-se nas tabelas 16 e 19 e a taxa de variação mensal da inflação consta no apêndice ${ }^{28}$.

A variável dependente é o índice de pobreza de Sen $(P)$ ou o índice de $F G T$, e as variáveis explanatórias são a renda média $(\mu)$, o índice de Gini $(G)$ e a taxa de inflação $(\psi)$. O modelo inclui um erro aleatório que representa todas as demais variáveis que afetam o nivel de pobreza absoluta e não foram incluidas no modelo. Os resultados obtidos mostram que as variações na medida de pobreza ( $P$ ou $F G T$ ) são explicadas, basicamente, pelas variações em $\mu$ e $G$, cujos coeficientes são estatisticamente diferentes de zero ao nível de significância de $1 \%$ nos modelos abaixo. Os outros modelos constam no apêndice.

$P=0,202+\underset{(19,069) \quad(-28,320) \quad(-0,605)}{0,271 \mu-0,008 \Psi}$

$\operatorname{com} \mathrm{R}^{2}=0,998$

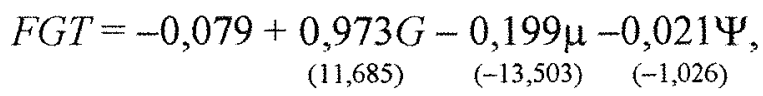

$\operatorname{com} \mathrm{R}^{2}=0,991$

Para esse periodo não se detecta, com os dados para o Piauí, influência direta da inflação sobre a pobreza, depois de considerada a influência da renda média e da desigualdade. Pode ser que não haja efeito da inflação sobre a pobreza, mas também pode ser que exista, manifestando-se por meio do efeito da inflação sobre a renda média e/ou a desigualdade.

\footnotetext{
${ }^{28}$ Essa relação funcional também foi testada considerando-se o Indice de Preços ao Consumidor (Custo de Vida) de Teresina, não ocorrendo alterações em comparação aos modelos ajustados com o INPC.
} 
Não foi possivel detectar o efeito do salário mínimo sobre a pobreza, mesmo ajustando-se modelos excluindo-se a inflação como variável explanatória, como no estudo de Lustig e McLeod (1996), que verificaram que um aumento (declínio) no SM real é acompanhado por uma queda (aumento) na pobreza. Essa relação inversa foi encontrada, considerando as observações em período de crescimento e recessão, para vários países da África, Ásia e América Latina.

Corrêa e Hoffmann (1997) constataram também a importância do salário mínimo como um dos determinantes da desigualdade da distribuição da renda na agricultura paulista no período 1981-90.

Hoffmann (1998, p.28) verificou para o Brasil no período de 1979-1996, considerando as pessoas economicamente ativas com algum rendimento, que o sinal do coeficiente do salário mínimo real é coerente com as várias pesquisas que mostram que aumentos no salário mínimo contribuem para reduzir a desigualdade e a pobreza. Ele afirma que "...o valor real do salário mínimo tem correlação parcial negativa $e$ estatisticamente significativa com as medidas de desigualdade".

A relação funcional entre o índice de Gini $(G)$, a renda média $(\mu)$, a inflação $(\Psi)$ e o salário mínimo (SM) é testada para o Piauí no período de 1984 a 1996. Os modelos ajustados (em apêndice) apresentaram baixo coeficiente de determinação, entretanto o sinal positivo do coeficiente de $\Psi$ é o esperado, porque sinaliza que a desigualdade da distribuição da renda cresce com a elevação da inflação, mas verifica-se que o coeficiente dessa variável não é estatisticamente diferente de zero. No que diz respeito à influência do salário mínimo sobre a desigualdade, nada se pode afirmar.

Portanto, os resultados das regressões não captaram uma influência direta da inflação mensal sobre o grau de desigualdade da distribuição da renda no Estado do 
Piauí. Como a inflação é um fenômeno da economia brasileira, reitera-se a possibilidade desse efeito se manifestar por meio do efeito sobre a renda média.

O Caderno Especial Emergentes, do Jornal Folha de São Paulo, de 27/11/96, aponta o Plano Real como responsável pela redução da pobreza. O impacto deste Plano econômico foi o de incluir novos consumidores, pessoas de baixa renda beneficiadas pelo fim do imposto inflacionário e que tiveram seu poder aquisitivo elevado.

Em contraposição, o DIEESE (1997) argumenta que a melhoria da distribuição pessoal da renda, que ocorre a partir de julho de 1994, pode ser atribuída ao fim do imposto inflacionário, mas apenas no momento da queda abrupta dos patamares de inflação. Nos meses posteriores, os fatores atuantes são o rápido crescimento da economia, a queda das taxas de desemprego e a mudança de preços relativos em favor dos serviços. Entretanto, esse processo redistributivo é comprometido a partir de março de 1995 com a interrupção da trajetória de crescimento da economia e aumento do desemprego, revertendo os ganhos nos preços relativos de serviços, esvaziando as causas de melhoria de renda no período pós-Real ${ }^{29}$.

Como já havia sido ventilado nos estudos de Hoffmann (1992 e 1995), a redução da inflação possibilita a diminuição da desigualdade e pobreza, lembrando o citado autor, em recente análise dos dados individuais das PNAD de 1995 para pessoas ocupadas na agricultura, que a desigualdade econômica no Brasil no período do Plano Real apresenta características muito similares às observadas em vários anos da década de 1980 e que é preciso que se confirme um crescimento sustentável do rendimento médio, ao invés de crescimento efềmero, como ocorreu em 1986 e 1989.

\footnotetext{
${ }^{29}$ O dado apresentado no estudo do DIEESE refere-se ao Índice de Gini para região metropolitana de São Paulo, de dezembro de 1989 a junho de 1997.
} 
5.2 Desigualdade econômica e pobreza absoluta em 1992, 1993 e 1995: análise dos dados individuais

Examinam-se as mudanças na composição qualitativa da PEA, em termos da situação do domicílio urbano ou rural $^{30}$, idade $^{31}$, sexo, instrução ${ }^{32}$ e condição de atividade do trabalho principal por faixa salarial, a partir das informações individuais das PNAD de 1992, 1993 e 1995

A composição etária e o sexo são características demográficas que, para Langoni (1973), só indiretamente podem ser afetadas por decisão política. Já a educação e as outras características têm um componente exógeno que é a ação do setor público, através de suas políticas.

A tabela 20 mostra alguns indicadores demográficos e econômicos no Piauí em 1992, 1993 e 1995. Verifica-se que, nos anos 90, a maioria da população piauiense reside em área urbana, mas ainda é significativa a participação da população rural (43,12\%) na população total, em 1995.

Entre as pessoas economicamente ativas com rendimento predomina o domicílio urbano (60,3\% em 1995) e as pessoas ocupadas são na sua maioria do sexo masculino $(63,2 \%)$, residem em área urbana $(63,8 \%)$ e desenvolvem atividades não agrícolas $(60,1 \%)$.

\footnotetext{
30 A área de localização tem como base a legislação vigente por ocasião da realização do Censo Demográfico de 1980. Como área urbana consideram-se as correspondentes às cidade (sedes municipais), às vilas (sedes distritais) ou as áreas urbanas isoladas. A área rural abrange toda a área situada fora desses limites. Este critério é, também, utilizado na classificação da população urbana e rural (IBGE, 1996, p. VIII).

${ }^{31}$ A idade foi calculada em relação à data de referência (30 de setembro de 1995) e as pessoas que não declararam a data de nascimento nem a idade presumida foram reunidas no grupo "idade ignorada".

32 Obtida em função da série e do grau que a pessoa estava frequèntando ou havia freqüentado, considerando a última série concluida com aprovação. As pessoas que não declararam a série e o grau ou com informaçốes incompletas ou que não permitissem a sua classificação foram reunidas no grupo de anos de estudo "não determinados ou sem declaração". Vide correspondência entre cada série concluida com aprovação e os anos de estudo em IBGE (1996, p.XV)
} 
Tabela 20. Indicadores demográficos e econômicos; Piauí - 1992, 1993 e 1995.

\begin{tabular}{|c|c|c|c|}
\hline \multirow[t]{2}{*}{ Indicadores } & \multicolumn{3}{|c|}{ Anos } \\
\hline & 1992 & 1993 & 1995 \\
\hline População total absoluto & 2.629 .702 & 2.665 .575 & 2.733 .098 \\
\hline $\mathrm{em} \%$ & 100,0 & 100,0 & 100,0 \\
\hline Urbana & 56,1 & 57,0 & 56,9 \\
\hline Rural & 43,9 & 43,0 & 43,1 \\
\hline População economicamente ativa (PEA) em \% & 59,4 & 63,8 & 64,1 \\
\hline População. Não economicamente ativa em $\%$ & 40,6 & 36,1 & 35,9 \\
\hline PEA com rendimento absoluto & 789.498 & 887.623 & 917.977 \\
\hline $\mathrm{em} \%$ & 100,0 & 100,0 & 100,0 \\
\hline Urbana & 62,1 & 61,7 & 60,3 \\
\hline Rural & 37,9 & 38,3 & 39,7 \\
\hline \multicolumn{4}{|l|}{ População Ocupada } \\
\hline por sexo absoluto & 787.043 & 884.367 & 913.809 \\
\hline em \% & 100,0 & 100,0 & 100,0 \\
\hline masculino & 66,1 & 62,3 & 63,2 \\
\hline feminino & 33,9 & 37,7 & 36,8 \\
\hline Por situação do domicilio absoluto & 787.043 & 884.367 & 913.809 \\
\hline $\mathrm{em} \%$ & 100,0 & 100,0 & 100,0 \\
\hline urbano & 62,0 & 61,6 & 60,1 \\
\hline rural & 38,0 & 38,4 & 39,9 \\
\hline Por setor de atividade absoluto & 787.043 & 884.367 & 913.809 \\
\hline $\mathrm{em} \%$ & 100,0 & 100,0 & 100,0 \\
\hline agricola & 36,2 & 36,9 & 36,2 \\
\hline não-agrícola & 63,8 & 63,1 & 63,8 \\
\hline Por nível de instrução absoluto & 780.169 & 881.113 & 909.641 \\
\hline em $\%$ & 100,0 & 100,0 & 100,0 \\
\hline Sem instrução & 34,6 & 33,0 & 33,6 \\
\hline 1 ano & 5,8 & 6,8 & 5,3 \\
\hline 2 anos & 7,2 & 8,0 & 7,9 \\
\hline 3 anos & 9,5 & 7,0 & 8,3 \\
\hline 4 anos & 11,3 & 12,8 & 10,9 \\
\hline 5 a 8 anos & 13,6 & 13,7 & 15,0 \\
\hline 9 a 11 anos & 13,5 & 13,8 & 14,7 \\
\hline mais de 12 anos & 4,4 & 4,9 & 4,3 \\
\hline Por idade & 787.043 & 884.367 & 913.809 \\
\hline em $\%$ & 100,0 & 100,0 & 100,0 \\
\hline 10 a 18 anos & 9,9 & 8,2 & 7,9 \\
\hline 19 a 24 anos & 13,2 & 16,0 & 15,1 \\
\hline 25 a 28 anos & 10,7 & 9,8 & 10,6 \\
\hline 29 a 38 anos & 26,2 & 26,4 & 22,9 \\
\hline 39 a 48 anos & 19,0 & 16,8 & 18,9 \\
\hline 49 a 59 anos & 12,5 & 12,4 & 14,1 \\
\hline 60 anos ou mais & 8,6 & 10,4 & 10,5 \\
\hline
\end{tabular}

Fonte: İBGE. Microdados das PNAD.

Nota: Exclusive sem declaração nas variáveis pesquisadas. 
O nivel de escolaridade das pessoas ocupadas que predomina é sem instrução, com as seguintes participações no total das pessoas que declararam nivel de instrução: $34,6 \%$ (1992), 33,0\% (1993) e 33,6\% (1995).

As tabelas 21, 22 e 23 mostram a distribuição da PEA com rendimento por classes de renda (em SM), segundo a situação do domicílio. As pessoas economicamente ativas com domicilio urbano têm maior participação na classe de renda de até 1/2 SM em 1992 e 1993 e de mais de 1/2 a 1 salário mínimo em 1995.

No domicílio rural, a faixa de renda predominante é até $1 / 2$ SM nos três anos. Nota-se que a participação da faixa de renda até $1 / 2$ SM decresceu, tanto no urbano quanto no rural, mas a redução foi maior no domicílio urbano. As frequeências relativas das faixas de renda de mais de $1 / 2$ a 2 cresceram na situação do domicílio urbano e rural. Pode-se deduzir que a PEA com menores rendimentos situa-se em área rural, perfazendo um percentual acumulado até 1 SM de $83 \%$ (1992), 84,5\% (1993) e 78,3\% (1995), enquanto no domicílio urbano a freqüência acumulada é de 65,7\% (1992),62,7\% (1993) e 50,8\% (1995), verificando-se ao longo desses anos um decréscimo na participação nas classes de renda até $1 \mathrm{SM}$. Isto indica que a PEA com rendimento situada no domicílio urbano e rural ascende nas classes de renda no anos 90 . 
Tabela 21. Freqüência, freqüência relativa e densidade de freqüência relativa das pessoas economicamente ativas com rendimento por classes de rendimento, segundo situação do domicílio; Piauí - 1992.

\begin{tabular}{|c|c|c|c|c|c|c|}
\hline \multirow[b]{2}{*}{$\begin{array}{l}\text { CLASSES DE } \\
\text { RENDA } \\
\text { (EM SM) }\end{array}$} & \multicolumn{3}{|c|}{ URBANO } & \multicolumn{3}{|c|}{ RURAL } \\
\hline & Frequêencia & $\begin{array}{l}\text { Frequência } \\
\text { relativa }\end{array}$ & $\begin{array}{l}\text { Densidade de } \\
\text { frequência } \\
\text { relativa }\end{array}$ & Frequiência & $\begin{array}{l}\text { Frequêencia } \\
\text { relativa }\end{array}$ & $\begin{array}{l}\text { Densidade de } \\
\text { frequência } \\
\text { relativa }\end{array}$ \\
\hline até $1 / 2$ & 187.554 & 38,2 & 76,4 & 179.206 & 60,0 & 120,0 \\
\hline mais de $1 / 2$ a 1 & 134.533 & 27,4 & 54,8 & 68.738 & 23,0 & 46,0 \\
\hline mais de 1 a 2 & 98.687 & 20,1 & 20,1 & 39.278 & 13,1 & 13,1 \\
\hline mais de 2 a 3 & 28.477 & 5,9 & 5,9 & 6.381 & 2,1 & 2,1 \\
\hline mais de 3 a 5 & 16.202 & 3,3 & 1,7 & 3.928 & 1,3 & 0,7 \\
\hline mais de 5 a 10 & 15.221 & 3,1 & 0,6 & 982 & 0,3 & 0,1 \\
\hline mais de 10 a 20 & 8.347 & 1,7 & 0,2 & $0^{(3)}$ & 0,0 & 0,0 \\
\hline mais de $20^{(2)}$ & 1.473 & 0,3 & 0,0 & 491 & 0,2 & 0,0 \\
\hline TOTAL & 490.494 & 100,0 & & 299.004 & 100,0 & \\
\hline
\end{tabular}

Fonte: BBGE. Microdados da PNAD de 1992.

(1) Valor do rendimento mensal de todas as fontes em valores reais constantes iguais ao maior salário mínimo de ago./1980, que é igual em moeda corrente a Cr\$ 651218 (1992). (2) Para o cálculo da densidade de frequência relativa fixou-se o extremo superior das classes em 60 salários minimos. (3) A freqựência é zero devido não constar observações na amostra.

Tabela 22. Freqüência, freqüência relativa e densidade de freqüência relativa das pessoas economicamente ativas com rendimento por classes de rendimento, segundo situação do domicílio; Piauí - 1993.

\begin{tabular}{|c|c|c|c|c|c|c|}
\hline \multirow[b]{2}{*}{$\begin{array}{l}\text { CLASSES DE } \\
\text { RENDA } \\
\text { (EM SM) }^{(1)}\end{array}$} & \multicolumn{3}{|c|}{ URBANO } & \multicolumn{3}{|c|}{ RURAL } \\
\hline & Frequêencia & $\begin{array}{l}\text { Frequêencia } \\
\text { relativa }\end{array}$ & $\begin{array}{l}\text { Densidade de } \\
\text { freqüência } \\
\text { relativa }\end{array}$ & Freqüência & $\begin{array}{l}\text { Frequência } \\
\text { relativa }\end{array}$ & $\begin{array}{c}\text { Densidade de } \\
\text { frequência } \\
\text { relativa }\end{array}$ \\
\hline até $1 / 2$ & 183.379 & 33,5 & 67,0 & 175.232 & 51,5 & 103,0 \\
\hline mais de $1 / 2$ a 1 & 160.059 & 29,2 & 58,4 & 112.324 & 33,0 & 66,0 \\
\hline mais de 1 a 2 & 108.505 & 19,8 & 19,8 & 38.521 & 11,3 & 11,3 \\
\hline mais de 2 a 3 & 42.866 & 7,8 & 7,8 & 7.057 & 2,1 & 2,1 \\
\hline mais de 3 a 5 & 26.581 & 4,7 & 2,4 & 3.257 & 1,0 & 0,5 \\
\hline mais de 5 a 10 & 15.735 & 2,9 & 0,6 & 2.714 & 0,8 & 0,2 \\
\hline mais de 10 a 20 & 7.052 & 1,3 & 0,1 & 542 & 0,2 & 0,0 \\
\hline mais de 20 & 3.256 & 0,6 & 0,0 & 543 & 0,2 & 0,0 \\
\hline TOTAL & 547.433 & 100,0 & & 340.190 & 100,0 & \\
\hline
\end{tabular}

Fonte: IBGE. Microdados da PNAD de 1993.

(1) Valor do rendimento mensal de todas as fontes em valores reais constantes iguais ao maior salário mínimo de ago./1980, que é igual em moeda corrente a $\mathrm{Cr} \$ 13057,63$ (1993). (2) Para o cálculo da densidade de frequência relativa fixou-se o extremo superior das classes em 60 salários mínimos. 
Tabela 23. Freqüência, freqüência relativa e densidade de freqüência relativa das pessoas economicamente ativas com rendimento por classes de rendimento, segundo situação do domicílio; Piauí - 1995.

\begin{tabular}{l|c|c|c|c|c|c}
\hline \multirow{2}{*}{\begin{tabular}{l} 
CLASSES DE \\
RENDA \\
\cline { 3 - 7 } (EM SM)
\end{tabular}} & Freqüência & $\begin{array}{c}\text { Frequência } \\
\text { relativa }\end{array}$ & $\begin{array}{c}\text { Densidade de } \\
\text { frequência } \\
\text { relativa }\end{array}$ & Frequência & $\begin{array}{c}\text { Frequência } \\
\text { relativa }\end{array}$ & $\begin{array}{c}\text { Densidade de } \\
\text { frequêencia } \\
\text { relativa }\end{array}$ \\
\hline até 1/2 & 107.843 & 19,5 & 39,0 & 149.524 & 41,0 & 82,0 \\
mais de 1/2 a 1 & 173,485 & 31,4 & 62,8 & 135.980 & 37,3 & 74,6 \\
mais de 1 a 2 & 129.727 & 23,5 & 23,5 & 62.518 & 17,1 & 17,1 \\
mais de 2 a 3 & 62.519 & 11,3 & 11,3 & 10.419 & 2,9 & 2,9 \\
mais de 3 a 5 & 36.991 & 6,7 & 3,4 & 2.084 & 0,6 & 0,3 \\
mais de 5 a 10 & 30.216 & 5,5 & 1,1 & 2.084 & 0,6 & 0,1 \\
mais de 10 a 20 & 9.378 & 1,7 & 0,2 & 521 & 0,1 & 0,0 \\
mais de 20 (2) & 3.125 & 0,6 & 0,0 & 1.563 & 0,4 & 0,0 \\
ToTAL & $\mathbf{5 5 3 . 2 8 4}$ & $\mathbf{1 0 0 , 0}$ & & $\mathbf{3 6 4 . 6 9 3}$ & 100,0 & \\
\hline
\end{tabular}

Fonte: IBGE. Microdados da PNAD de 1995.

(1) Valor do rendimento mensal de todas as fontes em valores reais constantes iguais ao maior salário minimo de ago./1980, que é igual em moeda corrente a $\mathrm{R} \$ 143,15$ (1995). (2) Para o cálculo da densidade de frequência relativa fixou-se o extremo superior das classes em 60 salários mínimos.

As figuras $12,13,14$ e 15 apresentam os dados dos rendimentos das pessoas economicamente ativas organizados em histogramas da renda, segundo o domicílio urbano e rural, em 1992 e 1995. Observa-se que a área de cada retângulo do histograma é proporcional à freqüência relativa da classe correspondente. 


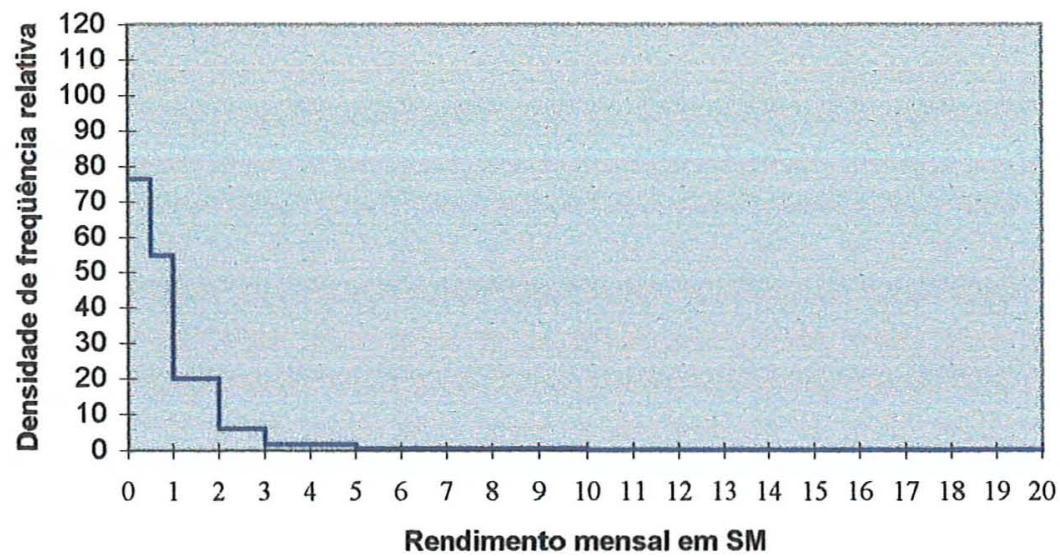

Figura 12. Histograma da renda para PEA com rendimento e domicílio urbano; Piauí 1992.

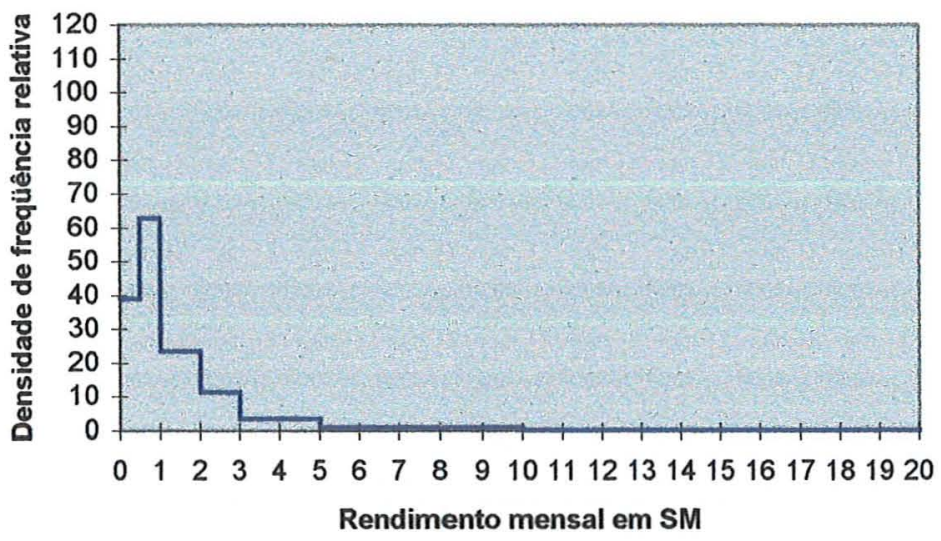

Figura 13. Histograma da renda para PEA com rendimento e domicílio urbano; Piauí 1995. 


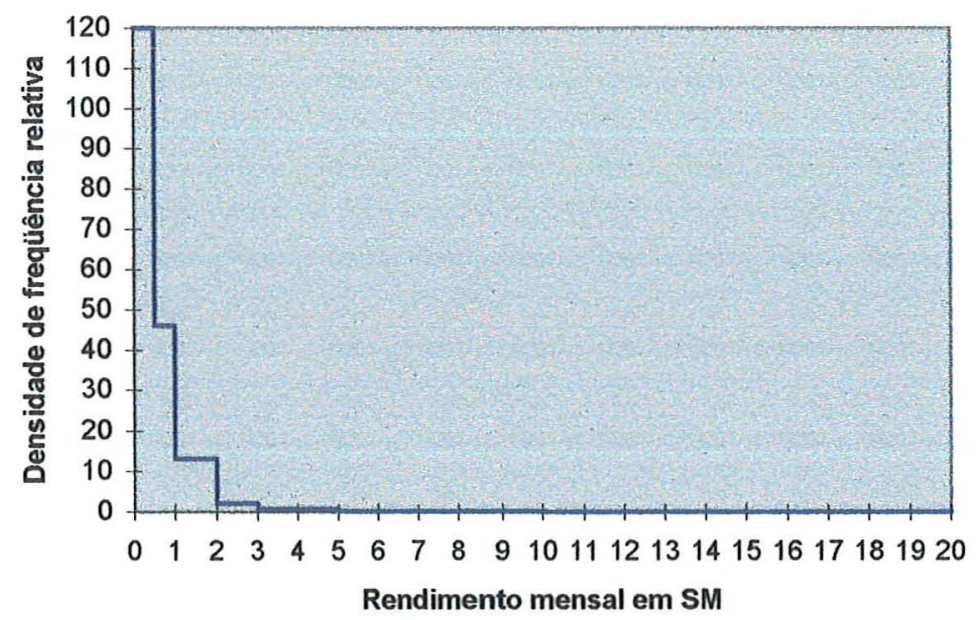

Figura 14. Histograma da renda para PEA com rendimento e domicílio rural; Piauí1992.

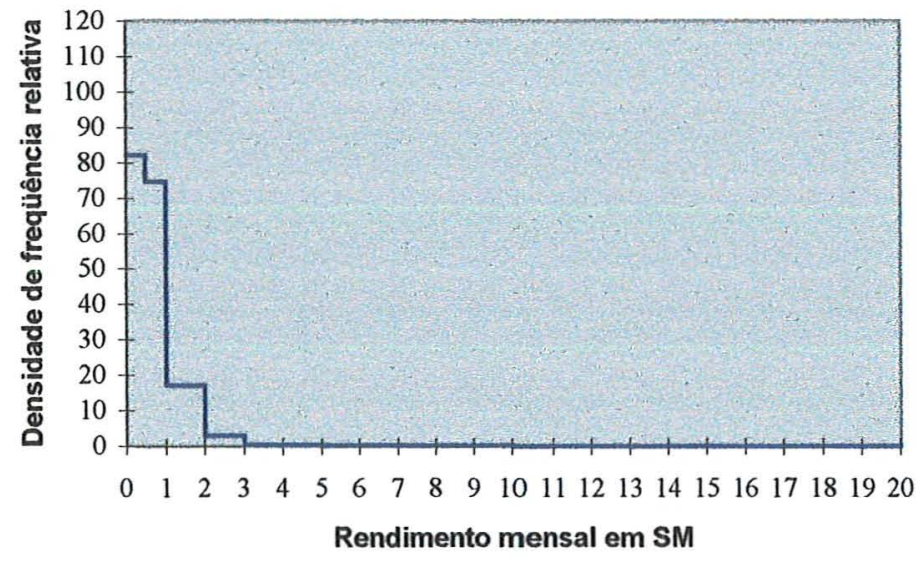

Figura 15. Histograma da renda para PEA com rendimento e domicílio rural; Piauí 1995. 
As tabelas 24,25 e 26 registram uma maior freqüência relativa de homens e mulheres na faixa salarial de até 1/2 SM em 1992 e 1993, sendo que em 1995 ocorre o aumento na participação na faixa mais de $1 / 2$ a 1 SM. Destaca-se que a PEA feminina diminui, sensivelmente, sua participação na faixa de até $1 / 2 \mathrm{SM}$, que era de $53,3 \%$ (1992), passando para 33,0\% (1995). Há, principalmente, o aumento da participação na faixa de 2 a 3 SM, que cresceu $165,5 \%$ e na faixa de 3 a 5 SM, que obteve variação de $253,8 \%$.

Tabela 24. Distribuição percentual da população economicamente ativa com rendimento por classes de rendimento, segundo sexo; Piauí - 1992.

\begin{tabular}{|c|c|c|c|c|c|c|}
\hline \multirow[b]{2}{*}{$\begin{array}{l}\text { CLASSES DE } \\
\text { RENDA } \\
\text { (EM SM) }^{(1)}\end{array}$} & \multicolumn{3}{|c|}{ MASCULINO } & \multicolumn{3}{|c|}{ FEMININO } \\
\hline & Frequência & $\begin{array}{l}\text { Frequência } \\
\text { relativa }\end{array}$ & $\begin{array}{l}\text { Densidade de } \\
\text { frequência } \\
\text { relativa }\end{array}$ & Frequêencia & $\begin{array}{l}\text { Frequêencia } \\
\text { relativa }\end{array}$ & $\begin{array}{l}\text { Densidade de } \\
\text { frequência } \\
\text { relativa }\end{array}$ \\
\hline até $1 / 2$ & 224.381 & 43,0 & 86,0 & 142.379 & 53,3 & 106,6 \\
\hline mais de $1 / 2$ a 1 & 134.041 & 25,7 & 51,4 & 69.230 & 25,9 & 51,8 \\
\hline mais de 1 a 2 & 99.177 & 19,0 & 19,0 & 38.788 & 14,5 & 14,5 \\
\hline mais de 2 a 3 & 27.002 & 5,2 & 5,2 & 7.856 & 2,9 & 2,9 \\
\hline mais de 3 a 5 & 16.693 & 3,2 & 1,6 & 3.437 & 1,3 & 0,7 \\
\hline mais de 5 a 10 & 12.275 & 2,4 & 0,5 & 3.928 & 1,5 & 0,3 \\
\hline mais de 10 a 20 & 6.874 & 1,3 & 0,1 & 1.473 & 0,6 & 0,1 \\
\hline mais de $20^{(2)}$ & 1.964 & 0,4 & 0,0 & $0^{(3)}$ & 0,0 & 0,0 \\
\hline TOTAL & 522.407 & 100,0 & & 267.091 & 100,0 & \\
\hline
\end{tabular}

Fonte: IBGE. Microdados da PNAD de 1992.

(1) Valor do rendimento mensal de todas as fontes em valores reais constantes iguais ao maior salário mínimo de ago./1980, que é igual em moeda corrente a Cr\$651218 (1992). (2) Para o cálculo da densidade de frequência relativa fixou-se o extremo superior da classe em 60 salários minimos. (3) A frequêencia é zero devido não constar observações na amostra. 
Tabela 25. Distribuição percentual da população economicamente ativa com rendimento por classes de rendimento, segundo sexo; Piauí - 1993.

\begin{tabular}{l|c|c|c|c|c|c}
\hline & \multicolumn{3}{|c|}{ MASCULINO } & \multicolumn{2}{c}{ FEMININO } \\
\cline { 2 - 7 } $\begin{array}{l}\text { CLASSES DE } \\
\text { RENDA } \\
\text { (EM SM) }\end{array}$ & Freqüência & $\begin{array}{c}\text { Freqüência } \\
\text { relativa }\end{array}$ & $\begin{array}{c}\text { Densidade de } \\
\text { frequência } \\
\text { relativa }\end{array}$ & $\begin{array}{c}\text { Frequêencia } \\
\text { relativa }\end{array}$ & $\begin{array}{c}\text { Densidade de } \\
\text { frequência } \\
\text { relativa }\end{array}$ \\
\hline até 1/2 & 203.447 & 36,8 & 73,6 & 155.164 & 46,4 & 92,8 \\
mais de 1/2 a 1 & 170.384 & 30,8 & 61,6 & 101.999 & 30,5 & 61,0 \\
mais de 1 a 2 & 105.796 & 19,1 & 19,1 & 41.230 & 12,3 & 12,3 \\
mais de 2 a 3 & 29.303 & 5,3 & 5,3 & 20.620 & 6,2 & 6,2 \\
mais de 3 a 5 & 22.784 & 4,1 & 2,1 & 7.054 & 2,1 & 4,2 \\
mais de 5 a 10 & 13.565 & 2,5 & 0,5 & 4.884 & 1,5 & 0,3 \\
mais de 10 a 20 & 4.881 & 0,9 & 0,1 & 2.713 & 0,8 & 0,1 \\
mais de 20 & 2.713 & 0,5 & 0,0 & 1.086 & 0,3 & 0,0 \\
ToTAL & $\mathbf{5 5 2 . 8 7 3}$ & $\mathbf{1 0 0 , 0}$ & & & $\mathbf{3 3 4 . 7 5 0}$ & $\mathbf{1 0 0 , 0}$ \\
\hline
\end{tabular}

Fonte: IBGE. Microdados da PNAD de 1993.

(1) Valor do rendimento mensal de todas as fontes em valores reais constantes iguais ao maior salário minimo de ago./1980, que é igual em moeda corrente a Cr\$13057,63 (1993). (2) Para o cálculo da densidade de frequência relativa fixou-se o extremo superior da classe em 60 salários mínimos.

Tabela 26. Distribuição percentual da população economicamente ativa com rendimento por classes de rendimento, segundo sexo; Piauí - 1995.

\begin{tabular}{|c|c|c|c|c|c|c|}
\hline \multirow[b]{2}{*}{$\begin{array}{l}\text { CLASSES DE } \\
\text { RENDA } \\
\left(_{(\text {EM SM })^{(1)}}\right.\end{array}$} & \multicolumn{3}{|c|}{ MASCULINO } & \multicolumn{3}{|c|}{ FEMININO } \\
\hline & Frequência & $\begin{array}{l}\text { Frequência } \\
\text { relativa }\end{array}$ & $\begin{array}{l}\text { Densidade de } \\
\text { freqüência } \\
\text { relativa }\end{array}$ & Frequêencia & $\begin{array}{l}\text { Frequência } \\
\text { relativa }\end{array}$ & $\begin{array}{c}\text { Densidade de } \\
\text { frequência } \\
\text { relativa }\end{array}$ \\
\hline até $1 / 2$ & 145.354 & 25,1 & 50,2 & 112.013 & 33,0 & 66,0 \\
\hline mais de $1 / 2$ a 1 & 183.385 & 31,7 & 63,4 & 126.080 & 37,1 & 74,2 \\
\hline mais de 1 a 2 & 144.316 & 25,0 & 25,0 & 47.929 & 14,1 & 14,1 \\
\hline mais de 2 a 3 & 46.888 & 8,1 & 8,1 & 26.050 & 7,7 & 7,7 \\
\hline mais de 3 a 5 & 23.445 & 4,1 & 2,1 & 15.630 & 4,6 & 2,3 \\
\hline mais de 5 a 10 & 24.485 & 4,2 & 0,8 & 7.815 & 2,3 & 0,5 \\
\hline mais de 10 a 20 & 7.294 & 1,3 & 0,1 & 2.605 & 0,8 & 0,1 \\
\hline mais de $20^{(2)}$ & 3.125 & 0,5 & 0,0 & 1.563 & 0,5 & 0,0 \\
\hline TOTAL & 578.292 & 100,0 & & 339.685 & 100,0 & \\
\hline
\end{tabular}

Fonte: Microdados da PNAD de 1995 divulgados pelo IBGE.

(1) Valor do rendimento mensal de todas as fontes em valores reais constantes iguais ao maior salário minimo de ago./1980, que é igual em moeda corrente a $\mathrm{R} \$ 143,15$ (1995). (2) Para o cálculo da densidade de frequência relativa fixou-se o extremo superior da classe em 60 salários mínimos.

$\mathrm{Na}$ figura 16 visualiza-se a predominância do sexo masculino na composição da PEA com rendimento, salientando-se que esse predomínio se verifica tanto no domicílio urbano quanto no rural. 


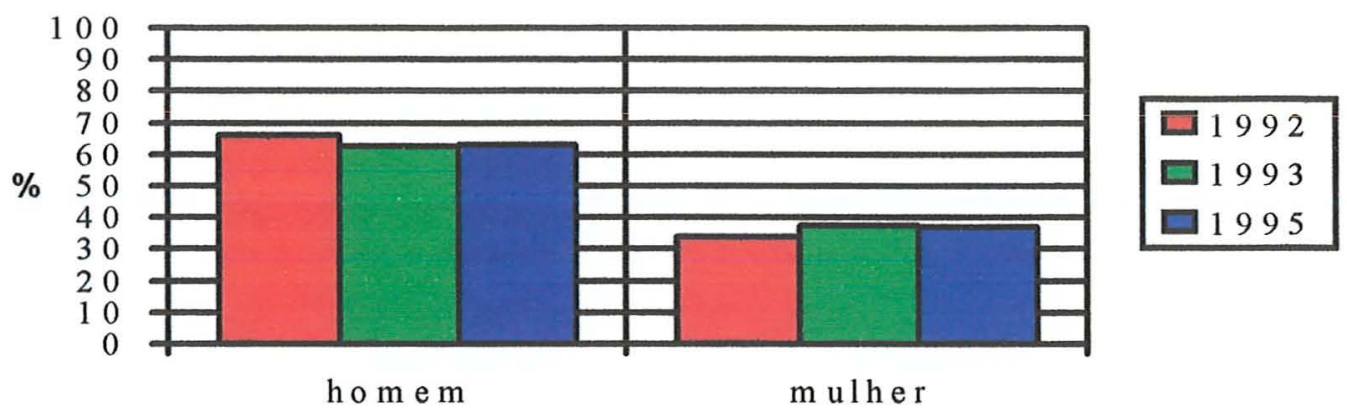

Figura 16. Proporção das pessoas economicamente ativas com rendimento, segundo o sexo; Piauí - 1992, 1993 e 1995

Observa-se nas tabelas 27, 28 e 29 que a renda aumenta com a idade, sendo que somente a partir dos 25 anos há pessoas nas faixas salariais acima de $10 \mathrm{SM}$. No grupo de idade de 10 a 14 anos e de 15 a 17 anos a freqüência relativa na faixa até $1 / 2$ SM é superior a 50\% em 1992, 1993 e 1995 . No grupo de 18 anos ocorre um crescimento significativo na freqüência relativa na faixa de $1 / 2$ a 1 SM.

Tabela 27. Distribuição percentual das pessoas economicamente ativas com rendimento por classes de rendimento, segundo idade; Piauí - 1992.

\begin{tabular}{|c|c|c|c|c|c|c|c|c|c|}
\hline \multirow[b]{2}{*}{$\begin{array}{l}\text { CLASSES } \\
\text { DE RENDA (EM SM) }{ }^{(1)}\end{array}$} & \multicolumn{9}{|c|}{ IDADE } \\
\hline & $\begin{array}{l}10 \text { a } 14 \\
\operatorname{anos}(\%)\end{array}$ & $\begin{array}{c}15 \text { a } 17 \\
\text { anos(\%) }\end{array}$ & $\begin{array}{c}18 \text { anos } \\
(\%)\end{array}$ & $\begin{array}{c}19 \text { a } 24 \\
\text { anos(\%) }\end{array}$ & $\begin{array}{c}25 \text { a } 28 \\
\operatorname{anos}(\%)\end{array}$ & $\begin{array}{c}29 \text { a } 28 \\
\operatorname{anos}(\%)\end{array}$ & $\begin{array}{c}39 \text { a } 48 \\
\text { anos(\%) }\end{array}$ & $\begin{array}{r}49 \text { a } 59 \\
\text { anos(\%) }\end{array}$ & $\begin{array}{l}60 \text { anos e } \\
\text { mais(\%) }\end{array}$ \\
\hline até $1 / 2$ & 94,6 & 85,5 & 74,4 & 58,1 & 48,0 & 43,6 & 36,6 & 44,5 & 15,3 \\
\hline mais de $1 / 2$ a 1 & 5,4 & 12,1 & 20,5 & 30,2 & 28,7 & 26,2 & 26,5 & 23,5 & 30,7 \\
\hline mais de 1 a 2 & 0,0 & 2,4 & 5,1 & 5,1 & 15,8 & 17,6 & 20,9 & 18,0 & 39,4 \\
\hline mais de 2 a 3 & 0,0 & 0,0 & 0,0 & 0,0 & 4,7 & 5,5 & 6,2 & 4,5 & 7,3 \\
\hline mais de 3 a 5 & 0,0 & 0,0 & 0,0 & 0,0 & 1,2 & 3,1 & 4,6 & 3,0 & 3,7 \\
\hline mais de 5 a 10 & 0,0 & 0,0 & 0,0 & 0,0 & 1,8 & 2,4 & 2,3 & 5,0 & 2,2 \\
\hline mais de 10 a 20 & 0,0 & 0,0 & 0,0 & 0,0 & 0,0 & 1,4 & 2,0 & 1,5 & 1,5 \\
\hline mais de 20 & 0,0 & 0,0 & 0,0 & 0,0 & 0,0 & 0,2 & 1,0 & 0,0 & 0,0 \\
\hline TOTAL & 100,0 & 100,0 & 100,0 & 100,0 & 100,0 & 100,0 & 100,0 & 100,0 & 100,0 \\
\hline
\end{tabular}

Fonte: IBGE. Microdados da P NAD de 1992.

(1) Valor do rendimento mensal de todas as fontes em valores réais constantes iguais ao maior salário mínimo de ago./1980, que é igual em moeda corrente a Cr\$651218 (1992). 
Tabela 28. Distribuição percentual das pessoas economicamente ativas com rendimento por classes de rendimento, segundo idade; Piauí -1993.

\begin{tabular}{|c|c|c|c|c|c|c|c|c|c|}
\hline \multirow[b]{2}{*}{$\begin{array}{l}\text { CLASSES } \\
\text { DERENDA (EM SM) }\end{array}$} & \multicolumn{9}{|c|}{ DADE } \\
\hline & $\begin{array}{l}10 \text { a } 14 \\
\operatorname{anos}(\%)\end{array}$ & $\begin{array}{r}15 \text { a } 17 \\
\operatorname{anos}(\%)\end{array}$ & $\begin{array}{c}18 \text { anos } \\
(\%)\end{array}$ & $\begin{array}{c}19 \text { a } 24 \\
\operatorname{anos}(\%)\end{array}$ & $\begin{array}{c}25 \text { a } 28 \\
\operatorname{ancs}(\%)\end{array}$ & $\begin{array}{l}29 \text { a } 28 \\
\text { anos }(\%) \\
\end{array}$ & $\begin{array}{l}39 \text { a } 48 \\
\text { anos }(\%) \\
\end{array}$ & $\begin{array}{l}49 \text { a } 59 \\
\operatorname{anos}(\%)\end{array}$ & $\begin{array}{l}60 \text { anos e } \\
\text { mais }(\%)\end{array}$ \\
\hline até $1 / 2$ & 96,6 & 88,4 & 72,2 & 53,2 & 44,0 & 39,5 & 32,7 & 34,0 & 3,6 \\
\hline mais de $1 / 2$ a 1 & 3,6 & 10,1 & 22,2 & 30,4 & 27,7 & 25,6 & 28,7 & 37,0 & 57,4 \\
\hline mais de 1 a 2 & 0,0 & 1,5 & 5,6 & 12,9 & 14,5 & 19,4 & 18,6 & 16,3 & 25,4 \\
\hline mais de 2 a 3 & 0,0 & 0,0 & 0,0 & 1,9 & 6,3 & 6,9 & 8,7 & 5,9 & 6,5 \\
\hline mais de 3 a 5 & 0,0 & 0,0 & 0,0 & 1,1 & 3,8 & 5,1 & 5,5 & 1,5 & 3,6 \\
\hline mais de 5 a 10 & 0,0 & 0,0 & 0,0 & 0,4 & 2,5 & 2,1 & 3,6 & 3,5 & 1,8 \\
\hline mais de 10 a 20 & 0,0 & 0,0 & 0,0 & 0,0 & 1,6 & 0,7 & 2,4 & 1,6 & 0,5 \\
\hline mais de 20 & 0,0 & 0,0 & 0,0 & 0,0 & 0,0 & 0,2 & 0,7 & 1,5 & 0,6 \\
\hline TOTAL & 100,0 & 100,0 & 100,0 & 100,0 & 100,0 & 100,0 & 100,0 & 100,0 & 100,0 \\
\hline
\end{tabular}

Fonte: IBGE. Microdados da PNAD de 1993.

(1) Valor do rendimento mensal de todas as fontes em valores redis constantes iguais ao maior salário mínino de ago./1980, que é igual em moeda corrente a $\mathrm{Cr} \$ 13057,63$ (1993).

Tabela 29. Distribuição percentual das pessoas economicamente ativas com rendimento por classes de rendimento, segundo idade; Piauí - 1995.

\begin{tabular}{|c|c|c|c|c|c|c|c|c|c|}
\hline \multirow[b]{2}{*}{$\begin{array}{l}\text { CLASSES } \\
\text { DE RENDA (EM SM) }\end{array}$} & \multicolumn{9}{|c|}{ IDADE } \\
\hline & $\begin{array}{l}10 \text { a } 14 \\
\text { anos }(\%)\end{array}$ & $\begin{array}{c}15 \text { a } 17 \\
\text { anos }(\%)\end{array}$ & $\begin{array}{c}18 \text { anos } \\
(\%)\end{array}$ & $\begin{array}{l}19 \text { a } 24 \\
\operatorname{anos}(\%)\end{array}$ & $\begin{array}{l}25 \text { a } 28 \\
\text { anos }(\%)\end{array}$ & $\begin{array}{r}29 \text { a } 28 \\
\text { anos }(\%)\end{array}$ & $\begin{array}{l}39 \text { a } 48 \\
\text { anos }(\%)\end{array}$ & $\begin{array}{l}49 \text { a } 59 \\
\text { anos }(\%)\end{array}$ & $\begin{array}{l}60 \text { anos e } \\
\text { mais }(\%)\end{array}$ \\
\hline até $1 / 2$ & 86,5 & 66,2 & 41,7 & 37,2 & 23,9 & 26,1 & 24,9 & 25,8 & 2,7 \\
\hline mais de $1 / 2$ a 1 & 13,5 & 31,2 & 58,3 & 36,8 & 37,2 & 30,0 & 26,7 & 31,9 & 50,8 \\
\hline mais de 1 a 2 & 0,0 & 2,6 & 0,0 & 21,1 & 21,8 & 21,6 & 20,4 & 24,2 & 29,7 \\
\hline mais de 2 a 3 & 0,0 & 0,0 & 0,0 & 3,0 & 8,5 & 10,9 & 11,4 & 8,1 & 7,6 \\
\hline mais de 3 a 5 & 0,0 & 0,0 & 0,0 & 1,1 & 4,8 & 5,5 & 8,4 & 2,4 & 3,8 \\
\hline mais de 5 a 10 & 0,0 & 0,0 & 0,0 & 0,8 & 2,1 & 4,2 & 6,0 & 4,8 & 3,8 \\
\hline mais de 10 a 20 & 0,0 & 0,0 & 0,0 & 0,0 & 1,6 & 0,7 & 2,4 & 1,6 & 0,5 \\
\hline mais de 20 & 0,0 & 0,0 & 0,0 & 0,0 & 0,0 & 1,0 & 0,0 & 1,2 & 1,1 \\
\hline TOTAL & 100,0 & 100,0 & 100,0 & 100,0 & 100,0 & 100,0 & 100,0 & 100,0 & 100,0 \\
\hline
\end{tabular}

Fonte: IBGE. Microdados da PNAD de 1995.

(1) Valor do rendimento mensal de todas as fontes em valores reais constantes iguais ao maior salário minimo de ago./1980, que e igual em moeda corrente a $\mathrm{R} \$ 143,15$ (1995).

As pessoas que recebem acima de 20 SM têm 29 anos ou mais, confirmando-se que com a idade o rendimento tende a ser maior, por um lado, pelo acúmulo de aprendizado e, por outro, porque os membros das famílias ricas ingressam, em geral, mais tarde na população economicamente ativa. A maioria dos elementos da PEA do 
Brasil na faixa de 10 a 19 anos de idade ainda fazem parte da família dos pais, segundo Hoffmann e Silva (1979).

Note-se que na década de 90 ocorreram modificações na estrutura etária da PEA, caracterizadas pela diminuição da participação do grupo etário de 10 a 18 anos, que foi de $9,9 \%$ em 1992 e passa para 7,9\% em 1995 .

O nível de escolaridade (anos de estudo) da PEA com rendimento é constatado nas tabelas 30,31 e 32 , mostrando que a freqüência relativa nas faixas salariais mais elevadas está associada com um maior nível de escolaridade, isto é, com aumento dos anos de estudo. Langoni (1973a), Corrêa (1995), Hoffmann (1996 e 1997) e muitos outros autores já verificaram esta associação positiva entre o maior nível educacional com o rendimento mais elevado.

A PEA sem instrução e menos de 1 ano de estudo no Piauí apresenta freqüência relativa acumulada de $80,3 \%(1992), 83,8 \%$ (1993) e $73,6 \%$ (1995) na faixa de renda de até $1 \mathrm{SM}$. 
Tabela 30. Distribuição percentual da população economicamente ativa, com rendimento por classes de rendimento, segundo anos de estudo (escolaridade); Piauí -1992.

\begin{tabular}{|c|c|c|c|c|c|c|c|c|c|}
\hline \multirow[b]{2}{*}{$\begin{array}{l}\text { CLASSES } \\
\text { DE RENDA (EM SM) }\end{array}$} & \multicolumn{9}{|c|}{ ESCOLARIDADE } \\
\hline & $\begin{array}{l}\text { sem instrução e } \\
\text { menos de } 1 \text { ano } \\
(\%)\end{array}$ & $\begin{array}{l}1 \text { ano } \\
(\%)\end{array}$ & $\begin{array}{c}2 \text { anos } \\
(\%)\end{array}$ & $\begin{array}{r}3 \text { anos } \\
(\%)\end{array}$ & $\begin{array}{r}4 \text { anos } \\
(\%)\end{array}$ & $\begin{array}{c}5 \text { a } 8 \\
\operatorname{anos}(\%)\end{array}$ & $\begin{array}{c}9 \text { a } 11 \\
\text { anos }(\%)\end{array}$ & $\begin{array}{c}12 \text { a } 15 \\
\operatorname{anos}(\%)\end{array}$ & $\begin{array}{c}\text { mais de } 15 \\
\text { anos }(\%)\end{array}$ \\
\hline até $1 / 2$ & 54,7 & 63,0 & 58,3 & 61,6 & 50,6 & 44,0 & 15,7 & 10,5 & 3,0 \\
\hline mais de $1 / 2$ a 1 & 25,6 & 22,8 & 19,1 & 23,2 & 24,5 & 29,8 & 33,6 & 26,3 & 3,0 \\
\hline mais de 1 a 2 & 16,6 & 9,8 & 15,7 & 9,9 & 19,4 & 17,0 & 21,7 & 42,1 & 30,3 \\
\hline mais de 2 a 3 & 2,2 & 2,2 & 3,5 & 2,0 & 1,7 & 3,7 & 13,8 & 10,5 & 9,1 \\
\hline mais de 3 a 5 & 0,6 & 2,2 & 5,3 & 2,0 & 3,3 & 2,8 & 5,5 & 5,3 & 6,1 \\
\hline mais de 5 a 10 & 0,4 & 0,0 & 0,0 & 0,7 & 0,6 & 2,3 & 6,0 & 2,6 & 24,2 \\
\hline mais de 10 a 20 & 0,0 & 0,0 & 0,0 & 0,7 & 0,0 & 0,5 & 3,7 & 0,0 & 18,2 \\
\hline mais de 20 & 0,0 & 0,0 & 0,0 & 0,0 & 0,0 & 0,0 & 0,0 & 2,6 & 6,1 \\
\hline TOTAL & 100,0 & 100,0 & 100,0 & 100,0 & 100,0 & 100,0 & 100,0 & 100,0 & 100,0 \\
\hline
\end{tabular}

Fonte: IBGE. Microdados da PNAD de 1992.

Nota: Informa-se que 6.874 (1992) pessoas não declararam nível de escolaridade.

(1) Valor do rendimento mensal de todas as fontes em valores reais constantes iguais ao maior salário mínimo de ago./1980, que é igual em moeda corrente a Cr\$651218 (1992).

Tabela 31. Distribuição percentual da população economicamente ativa, com rendimento por classes de rendimento, segundo anos de estudo (escolaridade); Piauí -1993.

\begin{tabular}{|c|c|c|c|c|c|c|c|c|c|}
\hline \multirow[b]{2}{*}{$\begin{array}{l}\text { CLASSES } \\
\text { DE RENDA (EM SM) }\end{array}$} & \multicolumn{9}{|c|}{ ESCOLARIDAE } \\
\hline & $\begin{array}{c}\text { sem instrução e } \\
\text { menos de } 1 \text { ano } \\
(\%)\end{array}$ & $\begin{array}{c}1 \text { ano } \\
(\%) \\
\end{array}$ & $\begin{array}{c}2 \text { anos } \\
(\%)\end{array}$ & $\begin{array}{r}3 \text { anos } \\
(\%) \\
\end{array}$ & $\begin{array}{r}4 \text { anos } \\
(\%) \\
\end{array}$ & $\begin{array}{c}5 \text { a } 8 \\
\operatorname{anos}(\%)\end{array}$ & $\begin{array}{c}9 \text { a } 11 \\
\text { anos }(\%)\end{array}$ & $\begin{array}{r}12 \text { a } 15 \\
\operatorname{anos}(\%)\end{array}$ & $\begin{array}{c}\text { mais de } 15 \\
\text { anos }(\%)\end{array}$ \\
\hline até $1 / 2$ & 48,5 & 52,2 & 46,2 & 44,7 & 54,3 & 35,7 & 13,2 & 14,0 & 2,9 \\
\hline mais de $1 / 2$ a 1 & 35,3 & 33,3 & 32,3 & 36,0 & 26,5 & 30,8 & 25,8 & 21,0 & 0,0 \\
\hline mais de 1 a 2 & 12,8 & 10,8 & 15,4 & 14,0 & 13,0 & 19,7 & 28,2 & 30,2 & 14,3 \\
\hline mais de 2 a 3 & 2,4 & 1,8 & 3,1 & 3,5 & 2,4 & 8,0 & 13,7 & 18,6 & 20,0 \\
\hline mais de 3 a 5 & 0,4 & 0,0 & 3,1 & 0,0 & 3,4 & 4,0 & 11,0 & 7,0 & 5,7 \\
\hline mais de 5 a 10 & 0,6 & 1,8 & 0,0 & 1,8 & 0,0 & 1,3 & 5,3 & 7,0 & 22,9 \\
\hline mais de 10 a 20 & 0,0 & 0,0 & 0,0 & 0,0 & 0,5 & 0,5 & 1,8 & 2,3 & 20,0 \\
\hline mais de 20 & 0,0 & 0,0 & 0,0 & 0,0 & 0,0 & 0,0 & 0,9 & 0,0 & 14,3 \\
\hline TOTAL & 100,0 & 100,0 & 100,0 & 100,0 & 100,0 & 100,0 & 100,0 & 100,0 & 100,0 \\
\hline
\end{tabular}

Fonte: BBGE. Microdados da PNAD de 1993.

Nola: Informa-se que 3.254 (1993) pessoas não decluraram nivel de escolaridade.

(1) Valor do rendimento mensal de todas as fontes em valores reais constantes iguais ao maior salário mínimo de ago./1980, que é igual em moeda corrente a Cr\$13057,63 (1993). 
Tabela 32. Distribuição percentual da população economicamente ativa com rendimento por classes de rendimento, segundo anos de estudo (escolaridade); Piauí -1995.

\begin{tabular}{|c|c|c|c|c|c|c|c|c|c|}
\hline \multirow[b]{2}{*}{$\begin{array}{l}\text { CLASSES } \\
\text { DE RENDA (EM SM) }\end{array}$} & \multicolumn{9}{|c|}{ ESCOLARIDADE } \\
\hline & $\begin{array}{c}\text { sem instrução e } \\
\text { menos de } 1 \text { ano } \\
(\%)\end{array}$ & $\begin{array}{c}1 \text { ano } \\
(\%) \\
\end{array}$ & $\begin{array}{c}2 \text { anos } \\
(\%)\end{array}$ & $\begin{array}{r}3 \text { anos } \\
(\%)\end{array}$ & $\begin{array}{r}4 \text { anos } \\
(\%) \\
\end{array}$ & $\begin{array}{c}5 \text { a } 8 \\
\operatorname{anos}(\%)\end{array}$ & $\begin{array}{c}9 \text { a } 11 \\
\operatorname{anos}(\%)\end{array}$ & $\begin{array}{c}12 \text { a } 15 \\
\text { anos }(\%)\end{array}$ & $\begin{array}{c}\text { mais de } 15 \\
\text { anos }(\%)\end{array}$ \\
\hline até $1 / 2$ & 31,4 & 47,3 & 32,4 & 35,2 & 35,4 & 26,1 & 12,7 & 0,0 & 0,0 \\
\hline mais de $1 / 2$ a 1 & 42,2 & 29,0 & 40,3 & 33,8 & 29,7 & 35,2 & 22,7 & 15,1 & 2,4 \\
\hline mais de 1 a 2 & 20,3 & 19,4 & 19,4 & 20,0 & 21,9 & 23,1 & 25,0 & 18,2 & 4,8 \\
\hline mais de 2 a 3 & 4,6 & 3,2 & 5,8 & 6,9 & 5,2 & 8,7 & 15,8 & 33,3 & 9,5 \\
\hline mais de 3 a 5 & 1,0 & 1,1 & 2,2 & 1,4 & 3,1 & 3,0 & 7,3 & 15,2 & 35,7 \\
\hline mais de 5 a 10 & 0,3 & 0,0 & 0,0 & 2,8 & 4,7 & 3,0 & 7,3 & 15,2 & 35,7 \\
\hline mais de 10 a 20 & 0,2 & 0,0 & 0,0 & 0,0 & 0,0 & 0,4 & 3,9 & 0,0 & 16,7 \\
\hline mais de 20 & 0,0 & 0,0 & 0,0 & 0,0 & 0,0 & 0,4 & 0,0 & 0,0 & 14,3 \\
\hline TOTAL & 100,0 & 100,0 & 100,0 & 100,0 & 100,0 & 100,0 & 100,0 & 100,0 & 100,0 \\
\hline
\end{tabular}

Fonte: IBGE. Microdados da PNAD de 1995 divulgados pelo IBGE.

Nota: Informa-se que 4.168 (1995) pessoas não declararam nivel de escolaridade.

(1) Valor do rendimento mensal de todas as fontes em valores reais constantes iguais ao maior salário mínimo de ago./1980, que é igual em moeda corrente a $\mathrm{R} \$ 143,15$ (1995).

Apresenta-se, na tabela 33, a composição do mercado de trabalho no Piauí, nesse período, registrando as pessoas ocupadas por categorias de inserção nesse mercado, conforme dados das PNAD sobre a posição na ocupação das pessoas economicamente ativas com rendimento. 
Tabela 33. Pessoas ocupadas no mercado de trabalho por forma de inserção; Piauí 1992,1993 e 1995.

\begin{tabular}{|c|c|c|c|c|c|}
\hline \multirow{2}{*}{\multicolumn{2}{|c|}{ Categorias de inserção }} & \multicolumn{3}{|c|}{ Anos } & \multirow{2}{*}{$\begin{array}{l}\text { Taxa anual de } \\
\text { crescimento } \\
1992 / 1995\end{array}$} \\
\hline & & 1992 & 1993 & 1995 & \\
\hline \multicolumn{2}{|l|}{ Total } & 787.043 & 884.367 & 913.809 & \\
\hline \multicolumn{2}{|c|}{ Distribuição relativa } & 100,0 & 100,0 & 100,0 & \\
\hline \multicolumn{2}{|l|}{ Empregadores } & 2,3 & 4,7 & 2,5 & 8,7 \\
\hline \multicolumn{2}{|c|}{ Empregados públicos ${ }^{(1)}$} & 7,9 & 9,3 & 9,0 & 13,9 \\
\hline \multicolumn{2}{|c|}{ Empregados particulares ${ }^{(2)}$} & 37,0 & 33,6 & 33,0 & $-10,8$ \\
\hline \multicolumn{2}{|c|}{ Trabalhadores autônomos ${ }^{(3)}$} & 43,8 & 39,8 & 41,0 & $-6,4$ \\
\hline \multicolumn{2}{|c|}{ Trabalhadores domésticos ${ }^{(4)}$} & 6,6 & 6,4 & 6,8 & 3,0 \\
\hline \multicolumn{2}{|c|}{ Não remunerados ${ }^{(5)}$} & 2,4 & 6,3 & 7,7 & 220,8 \\
\hline \multirow[t]{2}{*}{ Não-agricola } & absoluta & 501.782 & 557.751 & 583.504 & \\
\hline & em percentual & 63,8 & 63,1 & 63,9 & \\
\hline \multicolumn{2}{|c|}{ Distribuição relativa } & 100,0 & 100,0 & 100,0 & \\
\hline \multicolumn{2}{|c|}{ Empregadores } & 1,4 & 3,3 & 2,6 & 85,7 \\
\hline \multicolumn{2}{|c|}{ Empregados públicos ${ }^{(1)}$} & 12,4 & 14,7 & 14,1 & 13,7 \\
\hline \multicolumn{2}{|c|}{ Empregados particulares ${ }^{(2)}$} & 48,0 & 45,1 & 43,7 & $-9,0$ \\
\hline \multicolumn{2}{|c|}{ Trabalhadores autônomos ${ }^{(3)}$} & 27,7 & 25,8 & 28,0 & 1,1 \\
\hline \multicolumn{2}{|c|}{ Trabalhadores domésticos ${ }^{(4)}$} & 10,4 & 10,1 & 10,7 & 2,9 \\
\hline \multicolumn{2}{|c|}{ Não remunerados ${ }^{(5)}$} & 0,2 & 1,0 & 0,9 & 350,0 \\
\hline \multirow[t]{2}{*}{ Agrícola } & absoluta & 285.261 & 326.616 & 330.305 & \\
\hline & em percentual & 36,2 & 36,9 & 36,1 & \\
\hline \multicolumn{2}{|c|}{ Distribuição relativa } & 100,0 & 100,0 & 100,0 & \\
\hline \multicolumn{2}{|c|}{ Empregadores } & 3,8 & 7,0 & 2,4 & $-36,8$ \\
\hline \multicolumn{2}{|c|}{ Empregados particulares ${ }^{(2)}$} & 17,9 & 13,9 & 14,2 & $-20,7$ \\
\hline \multicolumn{2}{|c|}{ Trabalhadores autônomos ${ }^{(3)}$} & 72,1 & 63,8 & 63,7 & $-11,7$ \\
\hline \multicolumn{2}{|c|}{ Não remunerados ${ }^{(5)}$} & 6,2 & 15,3 & 19,7 & 217,7 \\
\hline
\end{tabular}

Fonte: IBGE. Microdados das PNAD de 1992, 1993 e 1995

(1) Inclui as categorias militar e funcionário público. (2) Inclui as categorias empregado com carteira assinada, outros e empregados sem declaração. (3) Inclui a categoria conta-própria. (4) Inclui as categorias doméstico com carteira, sem carteira e sem declaração. (5) Inclui as categorias trabalhador para produção proprio consumo, uso e não remunerados. 
Considerando-se o total das pessoas ocupadas em 1995, a categoria de maior frequêencia relativa é a dos trabalhadores autônomos $(41,0 \%)$ e, em segundo lugar, os empregados particulares (33\%). Na atividade não-agrícola destacam-se os empregados particulares $(43,7 \%)$ e os trabalhadores autônomos $(28,0 \%)$ e na atividade agrícola, os trabalhadores autônomos $(63,7 \%)$ e os não remunerados $(19,7 \%)$.

Registra-se o crescimento da categoria não remunerados na atividade nãoagrícola de $350,0 \%$ e $217,7 \%$ na atividade agrícola no período de 1992 a 1995. Observase que as categorias empregadores, empregados públicos, trabalhadores autônomos e trabalhadores domésticos na atividade não-agrícola obtiveram crescimento, exceção dos empregados particulares, que decrescem em 9,0\%. Na atividade agrícola, as categorias dos empregadores, empregados particulares e trabalhadores autônomos decresceram em $36,8 \%, 20,7 \%$ e $11,7 \%$, respectivamente.

Representa-se a composição do mercado de trabalho piauiense nas figuras 17 , 18, 19 e 20, conforme a atividade agrícola ou não-agrícola para 1992 e 1995. 

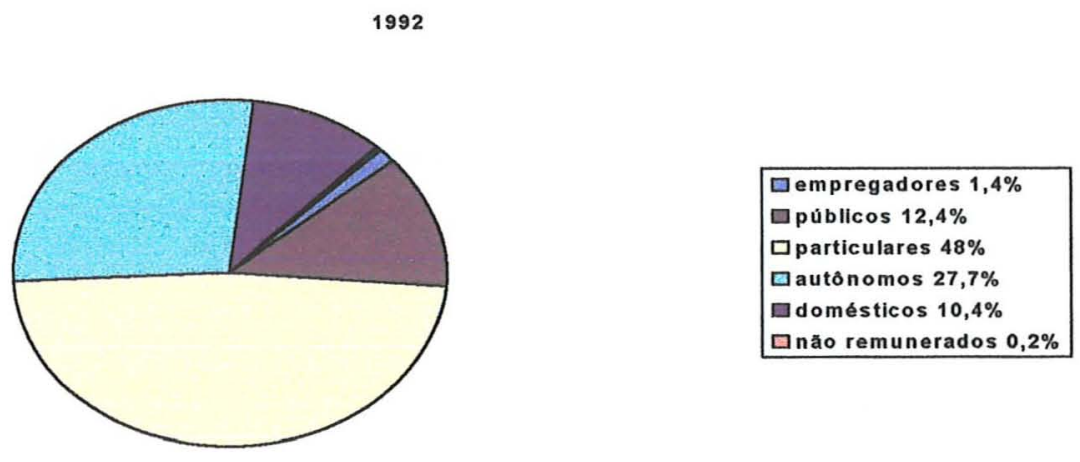

Figura 17. Pessoas ocupadas em atividade não-agrícola por formas de inserção; Piauí 1992.

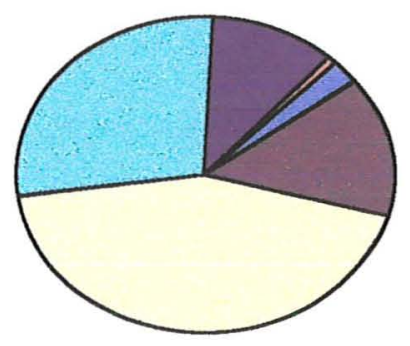

口empregadores $2,6 \%$

口 públicos $14,1 \%$

口 particulares $43,7 \%$

口autônomos $\mathbf{2 8 \%}$

$\square$ domésticos $10,7 \%$

口não remunerados $0,9 \%$

Figura 18. Pessoas ocupadas em atividade não-agrícola por formas de inserção; Piauí 1995. 


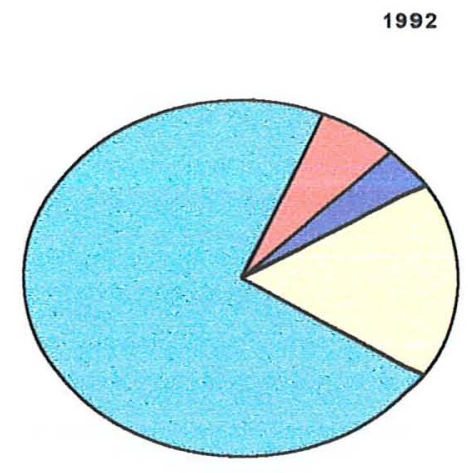

口empregadores $3,8 \%$

$\square$ públicos $0 \%$

口particulares $17,9 \%$

口autônomos $72,1 \%$

$\square$ domésticos $0 \%$

口não remunerados $6,2 \%$

Figura 19. Pessoas ocupadas em atividade agrícola por formas de inserção; Piauí 1992.

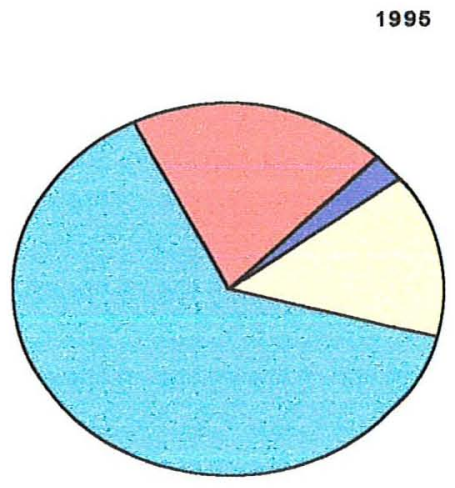

Dempregadores $2,4 \%$

$\square$ públicos $0 \%$

$\square$ particulares $14,2 \%$

$\square$ autônomos $63,7 \%$

口domésticos $0 \%$

$\square$ não remunerados $19,7 \%$

Figura 20. Pessoas ocupadas em atividade agrícola por formas de inserção; Piauí 1995.

As tabelas 34, 35 e 36 mostram que as pessoas que desenvolvem atividade agrícola se concentram, basicamente, na faixa até 1 SM, com 81,6\% (1992), 85,4\% (1993) e 80,1\% (1995). Na atividade não-agrícola essa participação se reduz para 66,8\% (1992), 62,7\% (1993) e 51,3\% (1995). Observa-se que em ambas as atividades os rendimentos de mais de $50 \%$ das pessoas ocupadas no Piauí estão na faixa de até $1 \mathrm{SM}$. 
Tabela 34. Distribuição percentual das pessoas ocupadas por classes de rendimento, segundo setor de atividade; Piauí - 1992.

\begin{tabular}{|c|c|c|c|c|c|c|}
\hline \multirow[b]{2}{*}{$\begin{array}{l}\text { CLASSES DE } \\
\text { RENDA } \\
\text { (EM SM) }\end{array}$} & \multicolumn{3}{|c|}{ AGRICOLA } & \multicolumn{3}{|c|}{ NÃO-AGRICOLA } \\
\hline & Freqüência & $\begin{array}{l}\text { Freqüência } \\
\text { relativa }\end{array}$ & $\begin{array}{c}\text { Densidade de } \\
\text { frequência } \\
\text { relativa } \\
\end{array}$ & Frequêencia & $\begin{array}{l}\text { Frequêencia } \\
\text { relativa }\end{array}$ & $\begin{array}{l}\text { Densidade de } \\
\text { frequêencia } \\
\text { relativa }\end{array}$ \\
\hline até $1 / 2$ & 168.899 & 59,2 & 118,4 & 195.897 & 39,0 & 78,0 \\
\hline mais de $1 / 2$ a 1 & 63.828 & 22,4 & 44,8 & 139.443 & 27,8 & 55,6 \\
\hline mais de 1 a 2 & 40.261 & 14,1 & 14,1 & 97.213 & 19,4 & 19,4 \\
\hline mais de 2 a 3 & 7.363 & 2,6 & 2,6 & 27.495 & 5,5 & 5,5 \\
\hline mais de 3 a 5 & 3.437 & 1,2 & 0,6 & 16.693 & 3,3 & 1,7 \\
\hline mais de 5 a 10 & 982 & 0,3 & 0,1 & 15.221 & 3,0 & 0,6 \\
\hline mais de 10 a 20 & $0^{(2)}$ & 0,0 & 0,0 & 8.347 & 1,7 & 0,2 \\
\hline mais de $20^{(3)}$ & 491 & 0,2 & 0,0 & 1.473 & 0,3 & 0,0 \\
\hline TOTAL & 285.261 & 100,0 & & 501.782 & 100,0 & \\
\hline
\end{tabular}

Fonte: IBGE. Microdados da PNAD de 1992.

(1) Valor do rendimento mensal de todas as fontes em valores reais constantes iguais ao maior salário mínimo de ago/1980, que é igual em moeda corrente a Cr\$651218 (1992). (2) A frequência é zero devido não constar observações na amostra. (3) Para o cálculo da densidade de frequência relativa fixou-se o extremo superior da classe em 60 salários minimos.

Tabela 35. Distribuição percentual das pessoas ocupadas por classes de rendimento, segundo setor de atividade; Piauí - 1993.

\begin{tabular}{l|c|c|c|c|c|c}
\hline \multirow{2}{*}{$\begin{array}{l}\text { CLASSES DE } \\
\text { RENDA }\end{array}$} & Frequência & $\begin{array}{c}\text { Frequência } \\
\text { relativa }\end{array}$ & $\begin{array}{c}\text { Densidade de } \\
\text { freqüência } \\
\text { relativa }\end{array}$ & Frequência & $\begin{array}{c}\text { Frequência } \\
\text { relativa }\end{array}$ & $\begin{array}{c}\text { Densidade de } \\
\text { frequência } \\
\text { relativa }\end{array}$ \\
\hline até 1/2 & 167.092 & 51,2 & 102,2 & 190.433 & 34,1 & 68,2 \\
mais de 1/2 a 1 & 111.777 & 34,2 & 68,4 & 158.978 & 28,5 & 57,0 \\
mais de 1 a 2 & 35.264 & 10,8 & 10,8 & 11.220 & 19,9 & 19,9 \\
mais de 2 a 3 & 9.512 & 2,0 & 2,0 & 43.411 & 7,8 & 7,8 \\
mais de 3 a 5 & 2.171 & 0,7 & 0,4 & 27.667 & 5,0 & 2,5 \\
mais de 5 a 10 & 2.172 & 0,7 & 0,1 & 16.277 & 2,9 & 0,6 \\
mais de 10 a 20 & 1.085 & 0,3 & 0,0 & 6.509 & 1,2 & 0,1 \\
mais de 20 (2) & 543 & 0,2 & 0,0 & 3.256 & 0,6 & 0,0 \\
ToTAL & $\mathbf{3 2 6 . 6 1 6}$ & $\mathbf{1 0 0 , 0}$ & & $\mathbf{5 5 7 . 7 5 1}$ & $\mathbf{1 0 0 , 0}$ & \\
\hline
\end{tabular}

Fonte: IBGE. Microdados da PNAD de 1993.

(1) Valor do rendimento mensal de todas as fontes em valores reais constantes iguais ao maior salário mínimo de ago/1980, gue é igual em moeda corrente a Cr\$13057,63 (1993). (2) Para o cálculo da densidade de frequência relativa fixou-se o extremo superior da classe em 60 salários mínimos. 
Tabela 36. Distribuição percentual das pessoas ocupadas por classes de rendimento, segundo setor de atividade; Piauí - 1995.

\begin{tabular}{|c|c|c|c|c|c|c|}
\hline \multirow[b]{2}{*}{$\begin{array}{l}\text { CLASSES DE } \\
\text { RENDA } \\
\text { (EM SM) }\end{array}$} & \multicolumn{3}{|c|}{ AGRÍCOLA } & \multicolumn{3}{|c|}{ NÃO-AGRÍCOLA } \\
\hline & Freqüência & $\begin{array}{l}\text { Freqüência } \\
\text { relativa }\end{array}$ & $\begin{array}{l}\text { Densidade de } \\
\text { frequência } \\
\text { relativa }\end{array}$ & Frequuência & $\begin{array}{l}\text { Frequêencia } \\
\text { relativa }\end{array}$ & $\begin{array}{c}\text { Densidade de } \\
\text { frequência } \\
\text { relativa }\end{array}$ \\
\hline até $1 / 2$ & 128.163 & 38,8 & 77,8 & 128.683 & 22,1 & 44,0 \\
\hline mais de $1 / 2$ a 1 & 136.498 & 41,3 & 82,6 & 170.883 & 29,3 & 58,6 \\
\hline mais de 1 a 2 & 54.182 & 16,4 & 16,4 & 137.542 & 23,6 & 23,6 \\
\hline mais de 2 a 3 & 8.336 & 2,5 & 2,5 & 64.602 & 11,1 & 11,1 \\
\hline mais de 3 a 5 & 2.084 & 0,6 & 0,3 & 36.991 & 6,3 & 3,2 \\
\hline mais de 5 a 10 & 1.042 & 0,3 & 0,1 & 30.216 & 5,2 & 1,0 \\
\hline mais de 10 a 20 & $0^{(3)}$ & 0,0 & 0,0 & 9.899 & 1,7 & 0,2 \\
\hline mais de 20 & $0^{(3)}$ & 0,0 & 0,0 & 4.688 & 0,8 & 0,0 \\
\hline TOTAL & 330.305 & 100,0 & & 583.504 & 100,0 & \\
\hline
\end{tabular}

Fonte: IBGE. Dados individuais da PNAD de 1995.

(1) Valor do rendimento mensal de todas as fontes em valores reais constanles iguais ao maior salário minimo de ago./1980, que é igual em moeda corrente a $\mathrm{R} \$ 143,15$ (1995). (2) Para o cálculo da densidade de frequência relativa fixou-se o extremo superior da classe em 60 salários mínimos. (3) A frequència é zero devido não constar observações na amostra,

O baixo rendimento das pessoas ocupadas traduz a própria composição do mercado de trabalho piauiense, onde 50,1\% dessas pessoas em 1995 desenvolveram atividades no setor serviços, sendo que as pessoas ocupadas que recebem maiores salários no estado desenvolvem atividades administrativas ou técnicas. No ano de 1995, na faixa salarial de 15 a $20 \mathrm{SM}$, as pessoas ocupadas em atividades administrativas participavam com $80 \%$ e, na faixa mais de $20 \mathrm{SM}$, as pessoas ocupadas atingem freqüência relativa de $55,6 \%$ em atividades técnicas e $22,3 \%$ em administrativas.

As figuras 21 e 22 para 1992, e 23 e 24 para 1995 mostram a distribuição do rendimento das pessoas ocupadas conforme a natureza agrícola ou não-agrícola da sua atividade principal. 


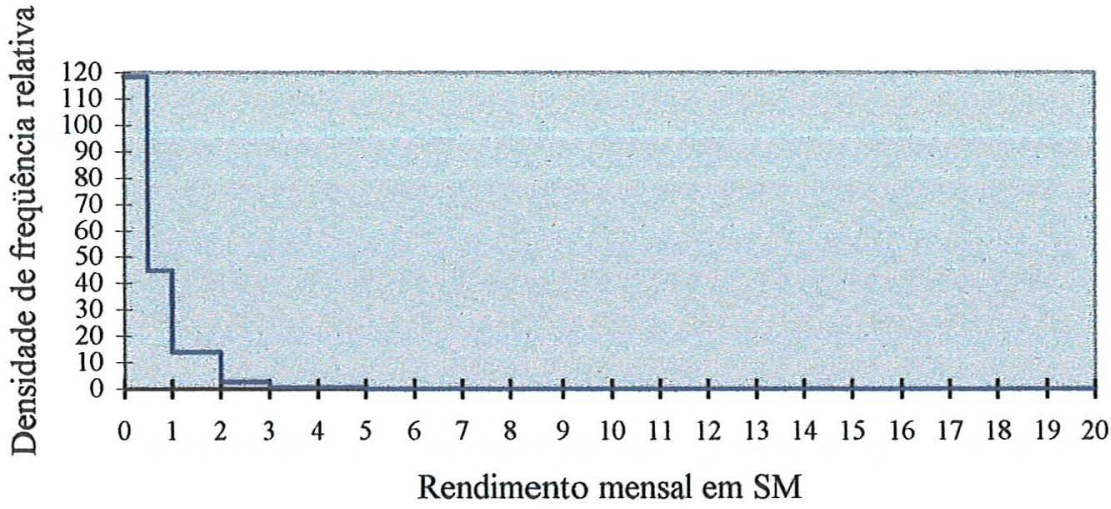

Figura 21. Histograma da renda para pessoas ocupadas na atividade agrícola; Piauí 1992.

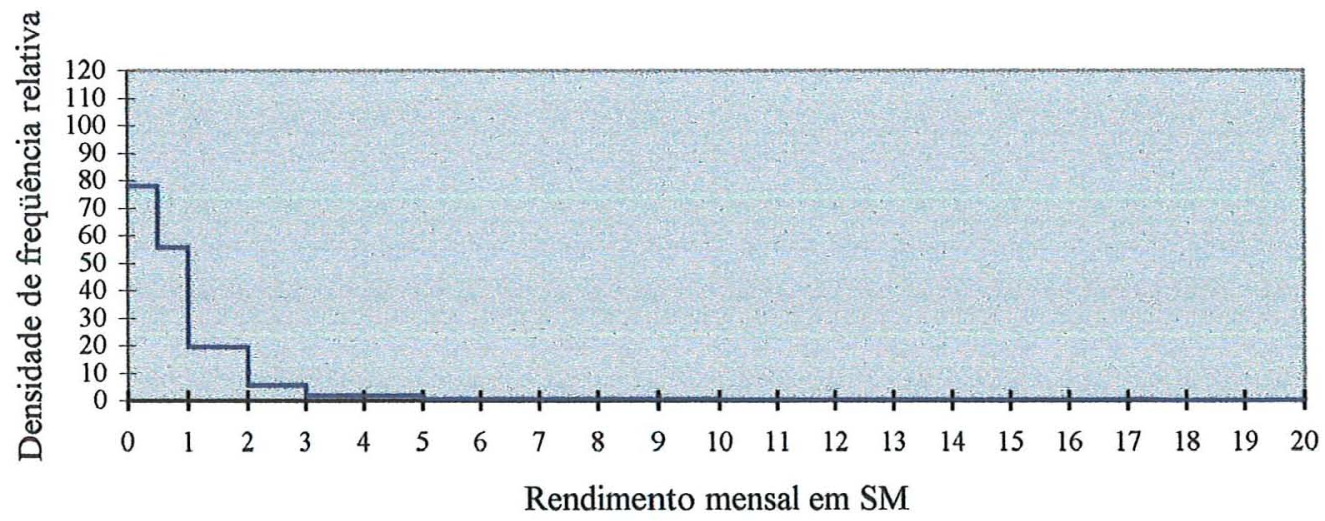

Figura 22. Histograma da renda para pessoas ocupadas na atividade não-agrícola; Piauí $-1992$. 


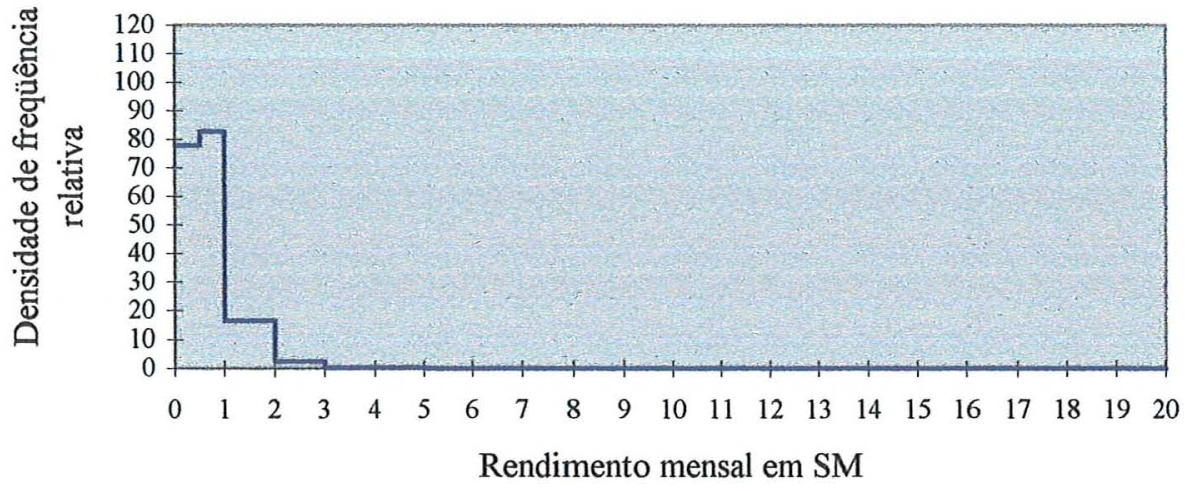

Figura 23. Histograma da renda para pessoas ocupadas na atividade agrícola; Piauí 1995.

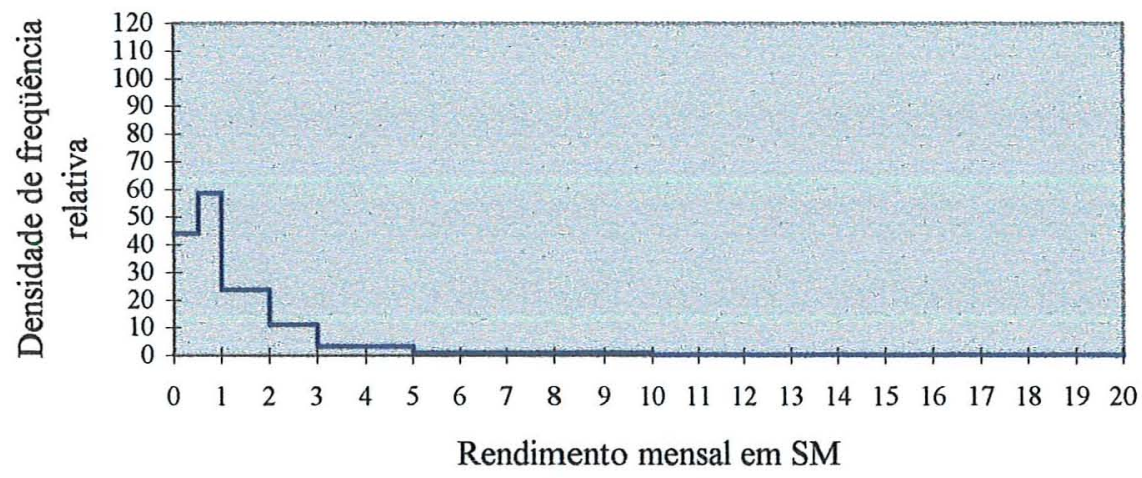

Figura 24. Histograma da renda para pessoas ocupadas na atividade não-agrícola; Piauí $-1995$.

Informa-se, ainda, que do total das pessoas economicamente ativas apenas $26,8 \%$ (1992), 26,2\% (1993) e 25,6\% (1995) contribuíram para Previdência, e, em 
contrapartida, 73,2\% (1992), 73,8\% (1993) e 74,4\% (1995) não o fizeram, verificandose um decréscimo dos contribuintes e acréscimo dos não contribuintes. Esse indicador sinaliza o crescimento das relações de trabalho informais no Estado do Piaui. Registrase, ainda, que 2.455 (1992), 3.256 (1993), 4.168 (1995) pessoas não declararam se contribuem ou não para a Previdência.

Em síntese, as pessoas economicamente ativas com rendimento compõe-se na sua maioria de homens (63\% em 1995) que residem em domicílio urbano $(60,3 \% \mathrm{em}$ $1995)$ e estão ocupados em atividades não-agrícolas ${ }^{33}$ (63,9\% em 1995). O nível de escolaridade ${ }^{34}$ é extremamente baixo. Estas características favorecem a compreensão da distribuição da renda e pobreza no Piauí.

\subsubsection{A desigualdade da distribuição da renda}

A desigualdade da distribuição da renda pode ser visualizada através das curvas de Lorenz, considerando as pessoas economicamente ativas e no domicílio urbano e rural, em 1992, 1993 e 1995.

Estas curvas mostram como a proporção da renda total $(\Phi)$ cresce em função da proporção da população $(p)$, considerando-se rendas crescentes per capita. Nas figuras, a seguir, o segmento de reta $\mathrm{OB}$ é denominado linha da perfeita igualdade e a poligonal OCB linha de perfeita desigualdade. Segundo Hoffmann (1997, p.22) "Dados sobre a distribuição da renda em qualquer país ou região correspondem, sempre, a uma curva de Lorenz situada dentro do triângulo $O B C$ ". A área compreendida entre a linha de perfeita igualdade e a curva de Lorenz é denominada área de desigualdade.

\footnotetext{
${ }^{33}$ Informa-se que 2.455 (1992), 3.256 (1993) e 4.168 (1995) pessoas não declararam.

${ }^{34}$ Informa-se que 6.874 (1992), 3.254 (1993) e 4.168 pessoas não declararam.
} 
Na figura 25 observa-se o crescimento da desigualdade de 1992 a 1993 e sua diminuição em 1995. A figura 26 apresenta uma diminuição da desigualdade de 1993 para 1995 mais acentuada no domicílio urbano e na figura 27 se verifica o crescimento da desigualdade na distribuição da renda na área rural, entre os mais ricos, em 1995, visto que a curva de Lorenz se distancia da linha de perfeita igualdade a partir do ponto em que a proporção acumulada da população é $80 \%$.

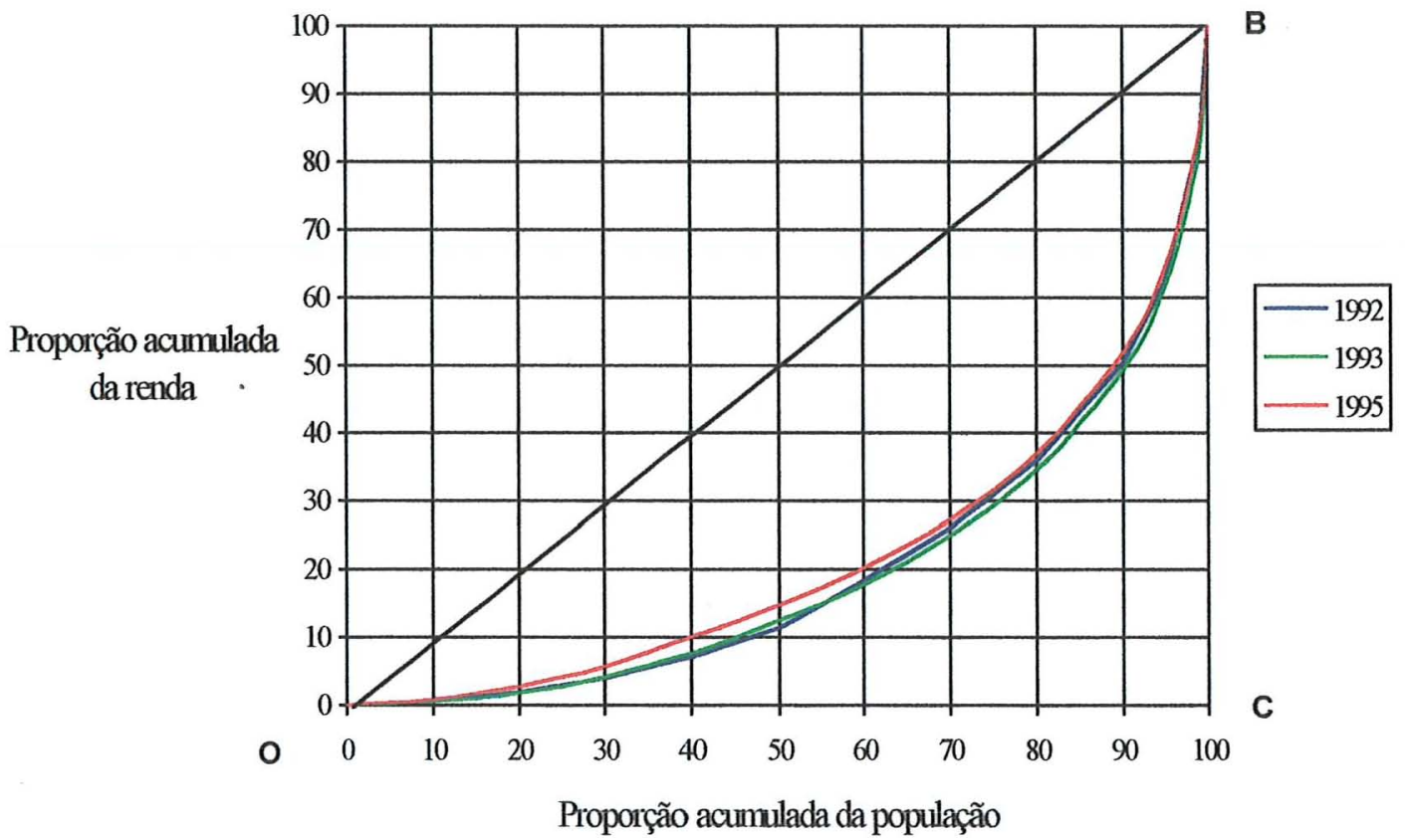

Figura 25. Curva de Lorenz para as pessoas economicamente ativas; Piauí -1992, 1993 e 1995. 


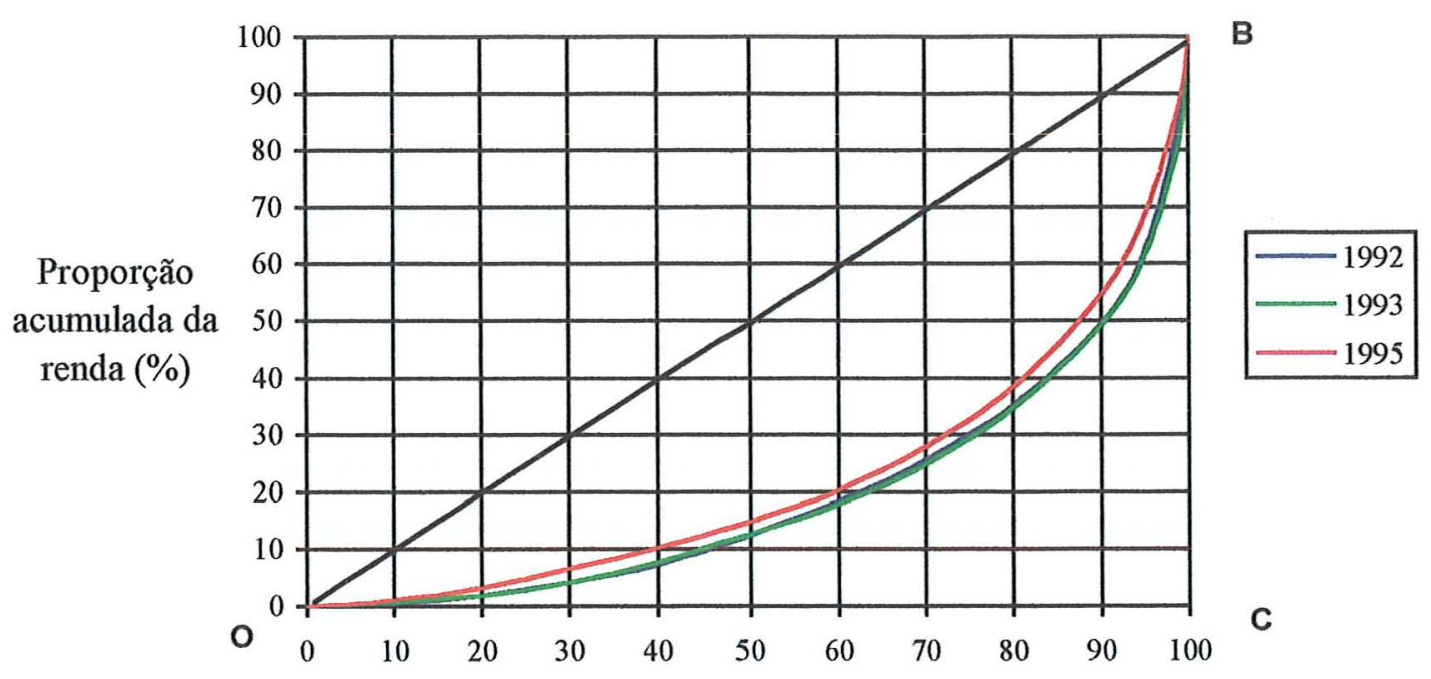

Proporção acumulada da população (\%)

Figura 26. Curva de Lorenz para as pessoas economicamente ativas com domicílio urbano; Piauí -1992, 1993 e 1995.

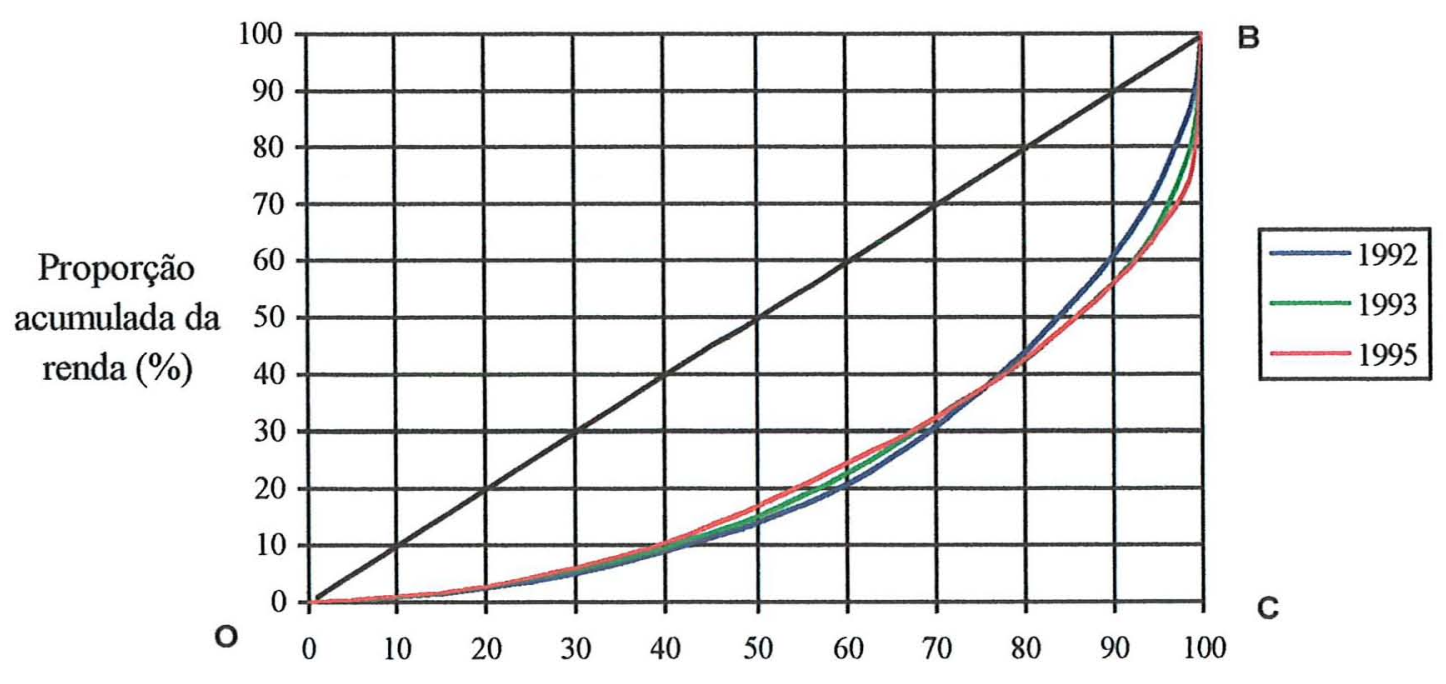

Proporção acumulada da população(\%)

Figura 27. Curva de Lorenz para as pessoas economicamente ativas com domicílio rural; Piauí ; 1992, 1993 e 1995. 
A tabela 37 registra a distribuição do rendimento da PEA total, de acordo com os percentis. O $p$-ésimo percentil é o valor do rendimento tal que $100 p \%$ da PEA tem rendimento igual ou menor.

Os resultados para 1992 mostram que o $40^{\circ}$ percentil é igual a $0,384 \mathrm{SM}$, isto é, $40 \%$ das pessoas têm rendimento menor ou igual a 0,384 SM. Em 1995, 40\% das pessoas têm rendimento menor ou igual a $0,699 \mathrm{SM}$, ocorrendo um acréscimo de $82,0 \%$ no valor do percentil.

Tabela 37. Distribuição do rendimento da população economicamente ativa (em percentis) e rendimento médio do estrato; Piauí - 1992, 1993 e 1995.

\begin{tabular}{|c|c|c|c|c|c|c|}
\hline \multirow{2}{*}{$\begin{array}{l}\text { Proporção } \\
\text { acumulada de } \\
\text { pessoas }\end{array}$} & \multicolumn{2}{|c|}{1992} & \multicolumn{2}{|c|}{1993} & \multicolumn{2}{|c|}{1995} \\
\hline & $\begin{array}{c}\text { percentis } \\
\text { (limite superior) }\end{array}$ & $\begin{array}{l}\text { rendimento } \\
\text { médio do } \\
\text { estrato }\end{array}$ & $\begin{array}{c}\text { percentis }^{(\mathrm{I})} \\
\text { (limite superior) }\end{array}$ & $\begin{array}{l}\text { rendimento } \\
\text { médio do } \\
\text { estrato }\end{array}$ & $\begin{array}{c}\text { percentis }^{(1)} \\
\text { (limite superior) }\end{array}$ & $\begin{array}{l}\text { rendimento } \\
\text { médio do } \\
\text { estrato }\end{array}$ \\
\hline 10 & 0,107 & 0,062 & 0,115 & 0,077 & 0,210 & 0,125 \\
\hline 20 & 0,184 & 0,142 & 0,211 & 0,170 & 0,349 & 0,290 \\
\hline 30 & 0,307 & 0,236 & 0,345 & 0.270 & 0,559 & 0,437 \\
\hline 40 & 0,384 & 0,339 & 0,498 & 0,407 & 0,699 & 0,653 \\
\hline 50 & 0,614 & 0,491 & 0,736 & 0,633 & 0,699 & 0,699 \\
\hline 60 & 0,802 & 0,747 & 0,736 & 0,736 & 0,978 & 0,818 \\
\hline 70 & 0,938 & 0,849 & 0,961 & 0,828 & 1,188 & 1,051 \\
\hline 80 & 1,259 & 1,092 & 1,424 & 1,167 & 1,746 & 1,435 \\
\hline 90 & 2,030 & 1,592 & 2,267 & 1,761 & 2,794 & 2,214 \\
\hline 95 & 3,480 & 2,570 & 3,829 & 2,880 & 5,134 & 3,715 \\
\hline 99 & 11,133 & 5,979 & 11,488 & 6,044 & 13,971 & 7,542 \\
\hline 100 & & 17,675 & & 23,939 & & 22,915 \\
\hline
\end{tabular}

Fonte: IBGE. Microdados das PNAD de 1992, 1993 e 1995

(1) O percentil é dado em unidades de valor real igual ao maior salário minimo vigente em agosto de 1980 (utilizando o INPC restrito como deflator).

O rendimento médio do estrato indica o rendimento médio das pessoas de um estrato delimitado por percentis, verificando-se que o rendimento médio do estrato delimitado pelo $40^{\circ}$ percentil e pelo $50^{\circ}$ percentil é igual a 0,339 SM (1992), 0,407 (1993) e 0,653 (1995), sendo a taxa de variação 20,1\% de 1992 a 1993 e 60,4\% de 1993 a 1995. 
As medidas de desigualdade da distribuição da renda entre as pessoas economicamente ativas constam na tabela 38 . Verifica-se que no período 1992-95 o Índice de Gini passou de 0,611 para 0,579 e o Índice de Theil de 0,552 para 0,517. No ano de 1993 ocorreu um ligeiro aumento dessas medidas em relação a 1992.

Tabela 38. Medidas de desigualdade conforme distribuição da renda entre as pessoas economicamente ativas com rendimento; Piauí - 1992, 1993 e 1995.

\begin{tabular}{|c|c|c|c|c|}
\hline \multicolumn{2}{|c|}{ ESTATÍSTICA } & 1992 & 1993 & 1995 \\
\hline \multirow{2}{*}{\multicolumn{2}{|c|}{ número de pessoas da amostra }} & 1.608 & 1.636 & 1.762 \\
\hline & & 789.498 & 887.623 & 917.977 \\
\hline \multicolumn{2}{|c|}{ Rendimento médio ${ }^{(1)}$} & 1,10 & 1,23 & 1,49 \\
\hline \multicolumn{2}{|c|}{ Rendimento mediano ${ }^{(1)}$} & 0,614 & 0,736 & 0,699 \\
\hline \multicolumn{2}{|c|}{ Índice de Gini } & 0,611 & 0,615 & 0,579 \\
\hline \multicolumn{2}{|c|}{ Índice de Theil } & 0,552 & 0,582 & 0,517 \\
\hline \multirow{3}{*}{$\begin{array}{l}\text { Participação na } \\
\text { renda total dos }\end{array}$} & $50 \%$ mais pobres & 11,6 & 12,7 & 14,8 \\
\hline & $10 \%$ mais ricos & 49,5 & 50,8 & 48,1 \\
\hline & $5 \%$ mais ricos & 37,8 & 39,1 & 35,7 \\
\hline \multirow[t]{3}{*}{$\begin{array}{l}\text { Razão entre a renda } \\
\quad \text { dos }\end{array}$} & $\begin{array}{l}1 \% \text { mais ricos e } \\
40 \% \text { mais pobres }\end{array}$ & 2,3 & 2,6 & 1,5 \\
\hline & $\begin{array}{l}5 \% \text { mais ricos e } \\
50 \% \text { mais pobres }\end{array}$ & 3,3 & 3,1 & 4,4 \\
\hline & $\begin{array}{l}10 \% \text { mais ricos e } \\
50 \% \text { mais pobres }\end{array}$ & 4,3 & 4,0 & 3,3 \\
\hline
\end{tabular}

Fonte: IBGEMicrodados das PNAD 1992, 1993 e 1995.

(1) Valores reais em unidades iguais ao maior salário mínimo de agosto de 1980, de acordo com o INPC restrito.

O rendimento médio aumentou $11,8 \%$ de 1992 a 1993 e 21,1\% de 1993 a 1995, e o rendimento mediano cresceu em $19,9 \%$ de 1992 a 1993, mas decresceu em 5\% de 1993 a 1995.

Os 50\% mais pobres tiveram uma participação na renda total de 11,6\% (1992), $12,7 \%$ (1993) e $14,8 \%$ (1995), enquanto os $10 \%$ mais ricos apropriam-se de $49,5 \%$ (1992), 50,8\% (1993) e 48,1\% (1995) da renda total, o que permite afirmar que os $50 \%$ 
mais pobres aumentaram sua participação na renda total em $9,7 \%$ de 1992 a 1993 e de $16,9 \%$ no periodo $1993-95$, e os $10 \%$ mais ricos quase que mantiveram a sua participação, porque apesar do decréscimo de 5,3\% de 1993 a 1995, houve uma elevação de $2,6 \%$ de 1992 a 1993, gerando uma redução na participação na renda total de $2,81 \%$ de 1992 a 1995 .

A diminuição da desigualdade da distribuição da renda nos anos 90 também pode ser visualizada pela razão entre a renda dos $1 \%$ mais ricos e dos $40 \%$ mais pobres, que decresce de 2,3 em 1992 para 1,5 em 1995. Isso indica que o rendimento médio das pessoas economicamente ativas que pertencem aos $1 \%$ mais ricos é 90,8 vezes maior que o rendimento médio das pessoas que fazem parte dos $40 \%$ mais pobres em 1992 e 60,8 vezes em 1995 .

Infere-se, com base nessas informações, que o Piauí não pode ser mais qualificado como um estado com distribuição da renda especialmente desigual quando comparado com o Nordeste e com o país como um todo. Verifica-se que as disparidades da distribuição da renda no Piauí se equipararam, nos anos 90 , às observadas para o Nordeste e para o Brasil (consulte o apêndice A.3.1.).

As tabelas 39 e 40 apresentam as medidas de desigualdade para a PEA com rendimento, considerando o domicílio rural e urbano. Verifica-se que a relação entre os rendimentos médios urbano e rural foi de 2,16 em 1992, 2,00 em 1993 e 2,03 em 1995, podendo-se afirmar que a diminuição da desigualdade de 1993 a 1995 está associada, basicamente, à diminuição da desigualdade dentro da área urbana.

Isso pode ser um indicador de que o controle da inflação com o Plano Real tem maior efeito no rendimento das pessoas economicamente ativas no domicílio urbano, porque a PEA urbana está mais integrada no mercado de trabalho formal. 
Tabela 39. Medidas de desigualdade da distribuição da renda entre as pessoas economicamente ativas com rendimento e domicílio urbano; Piauí 1992,1993 e 1995.

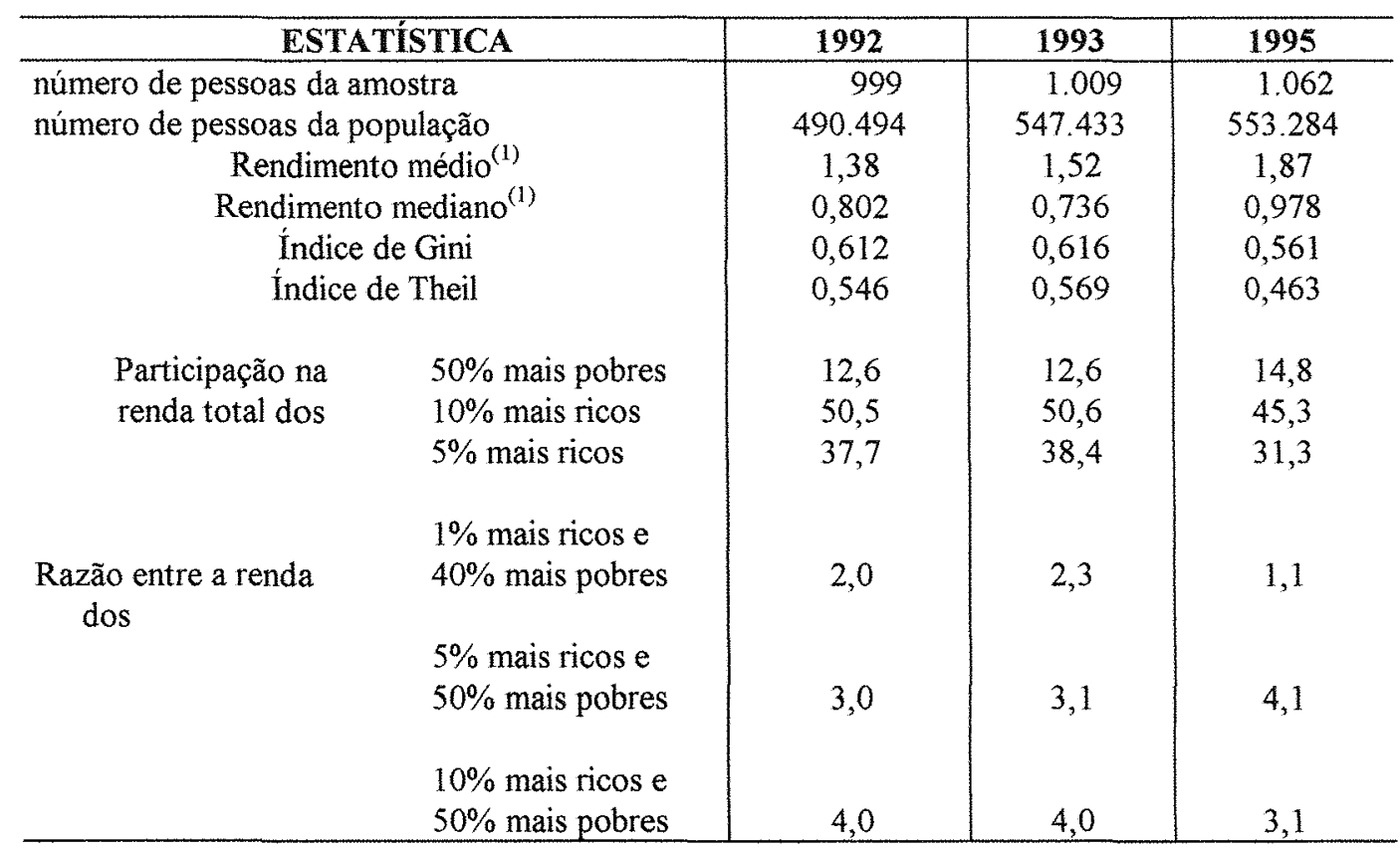

Fonte: IBGE. Microdados das PNAD 1992, 1993 e 1995.

(1) Valores reais em unidades iguais ao maior salário minimo de agosto de 1980, de acordo com o INPC restrito. 
Tabela 40. Medidas de desigualdade da distribuição da renda entre as pessoas economicamente ativas com rendimento e domicílio rural; Piauí - 1992, 1993 e 1995.

\begin{tabular}{|c|c|c|c|c|}
\hline \multicolumn{2}{|c|}{ ESTATISTICA } & 1992 & 1993 & 1995 \\
\hline \multicolumn{2}{|c|}{ número de pessoas da amostra } & 609 & 627 & 700 \\
\hline \multicolumn{2}{|c|}{ Número de pessoas da população } & 299.004 & 340.190 & 364.693 \\
\hline \multicolumn{2}{|c|}{ Rendimento médio ${ }^{(1)}$} & 0,64 & 0,76 & 0,92 \\
\hline \multicolumn{2}{|c|}{ Rendimento mediano ${ }^{(1)}$} & 0,38 & 0,46 & 0,68 \\
\hline \multicolumn{2}{|c|}{ Indice de Gini } & 0,540 & 0,547 & 0,540 \\
\hline \multicolumn{2}{|c|}{ Indice de Theil } & 0,441 & 0,533 & 0,572 \\
\hline Participação na & $50 \%$ mais pobres & 14,0 & 15,1 & 16,9 \\
\hline renda total dos & $10 \%$ mais ricos & 39,0 & 43,8 & 44,0 \\
\hline & $5 \%$ mais ricos & 27,1 & 33,9 & 34,9 \\
\hline \multirow{4}{*}{$\begin{array}{l}\text { Razão entre a renda } \\
\text { dos }\end{array}$} & $1 \%$ mais ricos $\mathrm{e}$ & & & \\
\hline & $40 \%$ mais pobres & 1,3 & 1,9 & 2,2 \\
\hline & $\begin{array}{l}5 \% \text { mais ricos e } \\
50 \% \text { mais pobres }\end{array}$ & 1,9 & 2,3 & 2,1 \\
\hline & $\begin{array}{l}10 \% \text { mais ricos e } \\
50 \% \text { mais pobres }\end{array}$ & 2,8 & 2,9 & 2,6 \\
\hline
\end{tabular}

Fonte: IBGE. Microdados das PNAD 1992, 1993 e 1995.

(1) Valores reais em unidades iguais ao maior salário minimo de agosto de 1980 , de acordo com o INPC restrito. 
O crescimento do rendimento médio e mediano, em situação de domicílio urbano e rural, é descrito na figura 28.

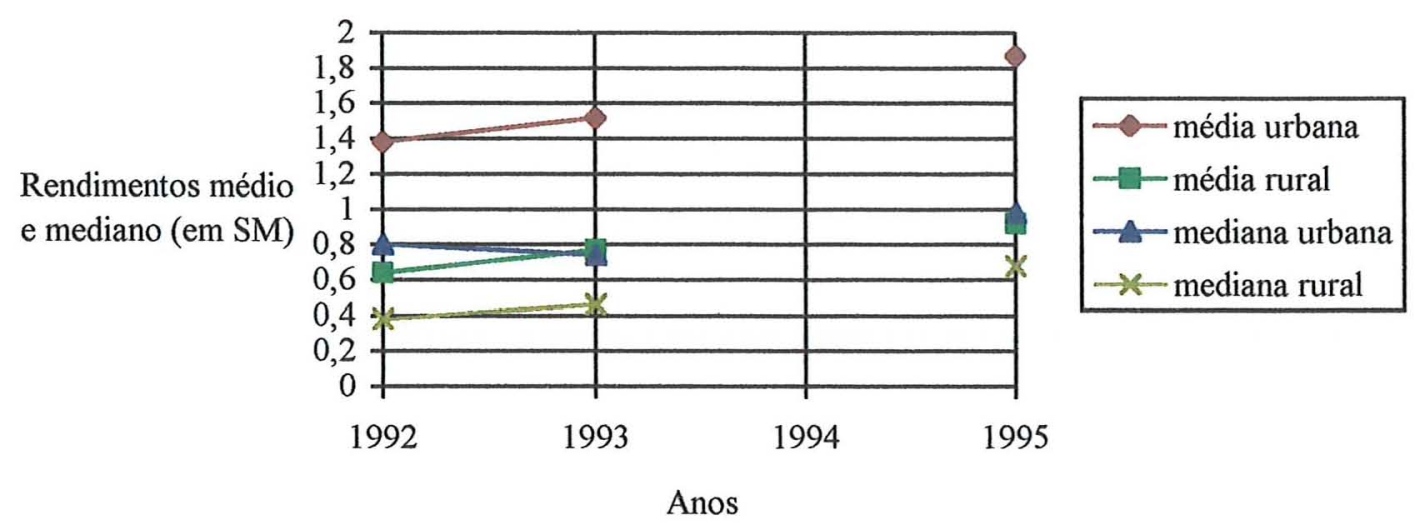

Figura 28. Rendimentos médio e mediano para pessoas economicamente ativas com rendimento, segundo situação do domicílio urbano ou rural; Piauí - 1992, 1993 e 1995.

Nota-se que o Índice de Gini é mais elevado no meio urbano e o Índice de Theil o é somente em 1992 e 1993, já que em 1995 capta uma maior desigualdade no domicílio rural. O índice de Gini decresceu em 8,3\% para a PEA com domicílio urbano, considerando o período de 1992 a 1995. Para a PEA com domicílio rural, esse índice se manteve inalterado de 1992 a 1995.

A figura 29 mostra a proporção da renda total apropriada pelos $50 \%$ mais pobres, 10\% mais ricos e 5\% mais ricos na PEA com domicílio urbano e rural em 1992, 1993 e 1995. 


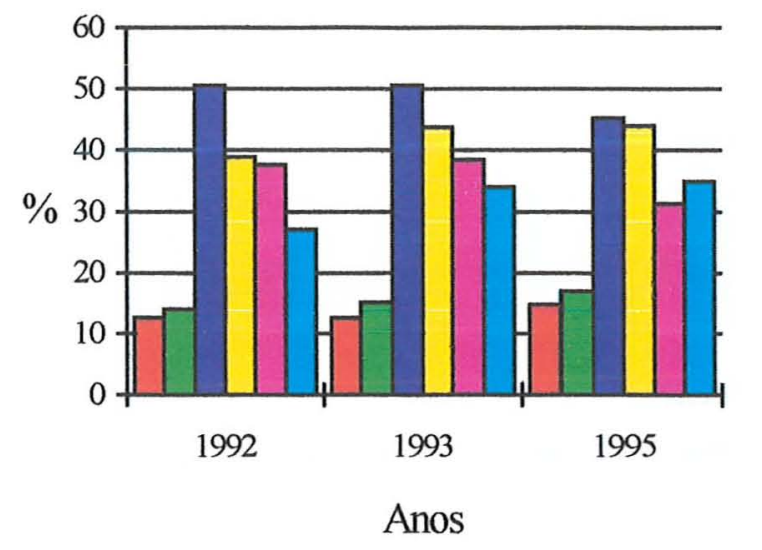
$\square 50 \%$ mais pobres no domicílio urbano
$\square 50 \%$ mais pobres no domicílio rural
$10 \%$ mais ricos no domićlio urbano
$\square 10 \%$ mais ricos no domicílio rural
$\square 5 \%$ mais ricos no domicílio urbano
$\square 5 \%$ mais ricos no domicílio rural

Figura 29. Proporção da renda apropriada pelos $50 \%$ mais pobres, pelos $10 \%$ mais ricos e pelos $5 \%$ mais ricos entre as pessoas economicamente ativas com rendimento, conforme situação do domicílio urbano ou rural; Piauí - 1992, 1993 e 1995.

A proporção da renda apropriada pelos $50 \%$ mais pobres é menor na zona urbana do que na rural para todos estes anos. A parcela da renda apropriada pelos $10 \%$ mais ricos é maior no meio urbano, o mesmo ocorrendo para os $5 \%$ mais ricos.

Em síntese, verificou-se que a desigualdade não acompanhou o crescimento contínuo do rendimento médio nos anos de 1992, 1993 e 1995, porque esta se eleva no período de 1992 a 1993 e cai de 1993 a 1995.

\subsubsection{Componentes "estruturais" da desigualdade da distribuição da renda}

Examina-se, para a PEA com rendimento, a influência do sexo, da idade, do grau de instrução, da situação do domicílio (urbano ou rural), da posição na ocupação, da 
natureza da atividade no trabalho principal e do número de horas de trabalho na variação dos rendimentos do trabalho das pessoas economicamente ativas com rendimento.

O contexto da análise considera que com a implantação do Plano Real (1994) ocorre uma queda acentuada da taxa de variação mensal da inflação de 35,6\% em 1993 para 1,17\% em 1995 (mês de referência da PNAD). A inflação é um mecanismo que reduz o poder de compra do rendimento do trabalho e redistribui a renda em favor dos segmentos que conseguem proteger parcialmente seus rendimentos mensais, porque as regras de aumentos salariais não obedecem a uma indexação plena.

Por outro lado, o controle da inflação favorece ao aumento do rendimento via estabilização de preços, possibilitando o acesso de pessoas de baixa renda ao mercado, principalmente das que residem em áreas urbanas. A redução da taxa de inflação afeta a renda média, contribuindo para sua elevação, entretanto não resolve as causas "estruturais" dos desniveis da renda, na medida que a desigualdade continua existindo e em niveis elevados, se comparados aos indicadores a nível mundial.

A influência dos fatores estruturais no rendimento das pessoas economicamente ativas foi captada através do modelo de regressão múltipla, incluindo um conjunto de variáveis binárias que assumem valor 1 ou zero, conforme a característica correspondente, seja ou não observada, utilizando o Procedure GLM/SAS para estimar as equações de rendimento.

As variáveis binárias foram definidas da seguinte forma:

1. uma variável binária para distinguir a situação do domicílio urbano ou rural, indicada por $R$.

2. uma variável binária para distinguir os dois sexos, indicada por $S$.

3. um conjunto de 8 variáveis binárias para as 9 faixas de idade: 10 a 14 anos, 15 a 17 anos, 18 a 19 anos, 20 a 24 anos, 25 a 29 anos, 30 a 39 anos, 40 a 49 anos, 50 a 59 anos e 60 anos e mais, representadas por $D_{i}$, com $i=1, \ldots, 8$. 
4. um conjunto de 4 variáveis binárias para captar 5 niveis de escolaridade (anos de estudo ): sem instrução ou menos de um ano, 1 a 4 anos, 6 a 8 anos, 9 a 11 anos, 12 ou mais anos, indicadas por $E_{j}, \operatorname{com} j=1, \ldots, 4$.

5. um conjunto de cinco variáveis binárias para distinguir 6 categorias de posição na ocupação: empregado com carteira assinada, militar e funcionário público, outros empregados e empregados sem declaração, doméstica com carteira, sem carteira e sem declaração, conta-própria e empregadores, indicadas por $P_{h}, \operatorname{com} h=1, \ldots, 5$.

6. para o setor do trabalho principal considera-se uma binária para distinguir a atividade agricola e não agrícola, indicada por $T$.

7. quatro variáveis binárias para distinguir cinco níveis de horas de trabalho de todos os trabalhos: até 14 horas, 15 a 39 horas, 40 a 44 horas, 45 a 48 horas e 49 ou mais horas, indicadas por $V_{\boldsymbol{m}}, m=1, \ldots, 4$.

A variável dependente $(Y)$ é o logaritmo neperiano do rendimento mensal de todas as fontes e a forma funcional (ou equação de rendimentos ) é expressa por

$Y=\alpha+\psi R+\beta S+\sum_{i=1}^{8} \gamma_{i} D_{i}+\sum_{j=1}^{4} \omega_{j} E_{j}+\sum_{h=1}^{5} \theta_{h} P_{h}+\lambda T+\sum_{m=1}^{4} \delta_{m} V_{m}+u$

onde $u$ é um erro aleatório que representa os efeitos de todas as demais variáveis que afetam o logaritmo do rendimento e não foram incluídas no modelo. Os parâmetros foram estimados pelo método de mínimos quadrados ponderados, sendo o fator de ponderação, para cada pessoa da amostra, o fator de expansão fornecido pelo IBGE.

O modelo foi ajustado considerando-se uma amostra de 1.540 (1992), 1.405 (1993) e 1.500 (1995) observações da PEA com rendimento, sendo excluídas as pessoas com menos de 10 anos e as pessoas que não declararam escolaridade, posição na ocupação, atividade do trabalho principal e horas de trabalho, constituindo uma população de 756.111 (1992), 762.286 (1993) e 781.477 (1995) pessoas 
economicamente ativas, isto é, o ajuste do modelo foi feito apenas para a PEA com rendimento positivo (variável dependente) e com informação válida para todas as variáveis explanatórias consideradas.

Os coeficientes estimados indicam as estimativas dos diferenciais de rendimento associados a situação do domicílio, sexo, idade, escolaridade, posição na ocupação, setor de atividade do trabalho principal e horas de trabalho (tabela 41).

Tabela 41. Coeficientes da equação de regressão ajustada; Piauí- 1992, 1993 e 1995.

\begin{tabular}{|c|c|c|c|}
\hline \multirow[b]{2}{*}{ FATORES } & \multicolumn{3}{|c|}{ ANOS } \\
\hline & 1992 & 1993 & 1995 \\
\hline \multicolumn{4}{|c|}{ SITUAÇÃ́ DO DOMICÍLIO } \\
\hline urbano & 0,218 & 0,140 & 0,257 \\
\hline rural & 0,000 & 0,000 & 0,000 \\
\hline \multicolumn{4}{|l|}{ SEXO } \\
\hline Homem & 0,754 & 0,557 & 0,439 \\
\hline Mulher & 0,000 & 0,000 & 0,000 \\
\hline \multicolumn{4}{|l|}{ IDADE } \\
\hline 10 a 14 anos & 0,000 & 0,000 & 0,000 \\
\hline 15 a 17 anos & 0,202 & $0,190^{*}$ & $0,227^{*}$ \\
\hline 18 a 19 anos & $0,410^{*}$ & 0,558 & 0,430 \\
\hline 20 a 24 anos & 0,489 & 0,647 & 0,476 \\
\hline 25 a 29 anos & 0,664 & 0,835 & 0,749 \\
\hline 30 a 39 anos & 0,839 & 1,004 & 0,826 \\
\hline 40 a 49 anos & 1,078 & 1,084 & 1,019 \\
\hline 50 a 59 anos & 1,218 & 1,292 & 1,040 \\
\hline 60 anos ou mais & 1,849 & 2,080 & 1,928 \\
\hline \multicolumn{4}{|l|}{ ESCOLARIDADE } \\
\hline sem instrução e menos de 1 ano & 0,000 & 0,000 & 0,000 \\
\hline 1 a 4 anos & 0,173 & 0,223 & 0,173 \\
\hline 5 a 8 anos & 0.401 & 0,524 & 0,321 \\
\hline 9 a 11 anos & 1,041 & 1,010 & 0,833 \\
\hline 12 anos ou mais & 1,548 & 1,586 & 1,600 \\
\hline \multicolumn{4}{|c|}{ POSIÇÃO NA OCUPAÇÃO } \\
\hline empregado com carteira. assinada & 0,000 & 0,000 & 0,000 \\
\hline funcionário. Público. & $0,003 *$ & $0,180^{*}$ & $0,177^{*}$ \\
\hline outros empregados. & $-0,586$ & $-0,577$ & $-0,254$ \\
\hline doméstica & $-0,690$ & $-0,915$ & $-0,414$ \\
\hline conta-própria & $-0,351$ & $-0,359$ & $-0,221$ \\
\hline empregadores & 0,323 & 0,356 & 0,547 \\
\hline \multicolumn{4}{|c|}{ ATIVIDADE PRINCIPAL } \\
\hline agricola & 0,000 & 0,000 & 0,000 \\
\hline nâo-agricola & 0,513 & 0,450 & 0,578 \\
\hline \multicolumn{4}{|c|}{ HORAS DE TRABALHO } \\
\hline até 14 & 0,000 & 0,000 & 0,000 \\
\hline 15 a 39 & 0,598 & $0,267 *$ & 0,386 \\
\hline 40 a 44 & 0,815 & 0,571 & 0,575 \\
\hline 45 a 48 & 0,862 & 0,661 & 0,738 \\
\hline 49 ou mais & 1,010 & 0,820 & 0,950 \\
\hline
\end{tabular}

Fonte: BBGE. Microdados das PNAD de 1992, 1993 e 1995.

Nota: Resultados do Procedure GLM/SAS.

Todos os coeficientes são estatisticamente significativos ao nivel de $1 \%$, exceto as categorias assinaladas com $(*)$. 
A tabela 42 revela os números de observações, os valores de $F$, os coeficientes de determinação e as contribuições marginais das variáveis sexo, idade, escolaridade e posição na ocupação, situação do domicílio, atividade do trabalho principal e horas de trabalho para 1992, 1993 e 1995.

Tabela 42. Número de observações, valores de $\mathrm{F}$ e $\mathrm{R}^{2}$ e contribuição marginal de cada fator $^{(1)}$ para o modelo estimado; Piauí- 1992, 1993 e 1995.

\begin{tabular}{c|c|c|c}
\hline ESTATISTICA & \multicolumn{3}{|c}{ ANOS } \\
\cline { 2 - 4 } & 1992 & 1993 & 1995 \\
\hline NƯMERO DE OBSERVAÇÕES & 1.540 & 1.405 & 1.500 \\
F $^{(2)}$ & 63,4 & 74,2 & 65,9 \\
COEFICIENTE DE DETERMINAÇÃO (\%) $^{(2)}$ & 50,1 & 56,3 & 51,7 \\
CONTRIBUIÇÃO MARGINAL $^{(2)}(\%)$ & & & \\
situação do domicílio $_{\text {sexo }}$ & 0,8 & 0,3 & 1,4 \\
idade & 10,7 & 5,5 & 4,6 \\
escolaridade & 16,9 & 15,3 & 17,0 \\
posição na ocupação & 14,9 & 13,7 & 17,3 \\
atividade principal & 5,7 & 8,9 & 4,4 \\
horas de trabalho & 3,3 & 2,5 & 4,9 \\
\hline
\end{tabular}

Fonte: 1BGE. Microdados das PNAD 1992, 1993 e 1995.

(1) Contribuição marginal do fator (SSI (fator) SSMODEL) conforme Procedure GLM/SAS, em percentual. (2) Os valores de F são estatisticamente significativos ao nivel de $1 \%$.

Todos os fatores considerados mostram influência estatisticamente significativa a nível de $1 \%$. O coeficiente de determinação indica que a equação de regressão explica $50,1 \%$ (1992), 56,3\% (1993) e 51,7\% (1995) das variações do logaritmo do rendimento das pessoas economicamente ativas. Como o rendimento individual é afetado por características pessoais cuja mensuração é praticamente impossível (ambição, tino comercial, etc), os coeficientes de determinação dessa ordem de grandeza são razoáveis em face da disponibilidade de informações e compatíveis com os obtidos por Langoni (1973), Ramos (1993), Corrêa (1995) e Hoffmann (1993a, 1994 e 1997).

Calcula-se a contribuição marginal que mostra a importância de cada fator como determinante das variações no logaritmo do rendimento $(Y)$, isto é, o aumento da parte 
explicada das variações de $Y$ obtido com a introdução da respectiva variável ou grupo de variáveis binárias, depois que todas as demais variáveis já tivessem sido incluídas.

Observa-se que as variáveis com maior poder explicativo são a idade e escolaridade, com contribuição marginal superior a 13\% nos três anos.

A idade foi considerada como uma proxy razoável para captar a contribuição do treinamento e experiência das pessoas, conforme estudos realizados por Langoni (1973a), Corrêa (1995) e Hoffmann (1996 e 1997), porque estaria traduzindo o aumento de produtividade associado ao aprendizado no próprio trabalho, a exploração dos diferenciais de produtividade existentes no mercado e o aumento real nas possibilidades de acumular capital físico.

No Piauí, este fator reflete também o fluxo de jovens na PEA piauiense. As pessoas com idade de 10 a 24 anos correspondem a 23\% do total da PEA em 1995 e concentram-se nas faixas salariais de até $2 \mathrm{SM}$.

As relações entre distribuição da renda e educação no Brasil foram analisadas por Senna (1976), Castello Branco (1979), Medeiros (1982) e Barros e Reis (1989). Esses autores concordam em que a maior escolaridade está associada com maior rendimento, apesar das limitações e críticas ${ }^{35}$.

No Piauí, o aumento do grau de escolaridade das pessoas economicamente ativas reflete-se na elevação dos rendimentos recebidos, visto que $30 \%$ das pessoas com 15 anos ou mais de estudo recebem mais de $20 \mathrm{SM}$ em 1995, sendo, portanto, um fator importante para explicar as variações dos rendimentos.

\footnotetext{
${ }^{35}$ Consulte Langoni (1973), Ramos (1993) e Corrêa (1995).
} 
As diferenças de renda atribuídas ao sexo, em grande parte, são rotuladas como "discriminação", justificada pelo menor potencial de força física feminina (limitando as possibilidades de emprego feminino nos níveis mais baixos de qualificação) e maiores riscos para a firma (ausência temporária do emprego no período de gestação). Essas diferenças existem independentemente da idade, da atividade ou do nível de educação.

É importante, então, verificar que a contribuição marginal do sexo na variação do rendimento no Piauí foi de $10,7 \%$ (1992), 5,5\% (1993) e 4,6\% (1995), podendo indicar que a diferença entre o rendimento do homem e da mulher diminui. Isso é comprovado pelos dados de que o rendimento esperado de um mulher é igual a $47,1 \%$ (1992), 57,3\% (1993) e 64,5\% (1995) do rendimento esperado de um homem.

A pequena contribuição desse fator em 1995 pode sinalizar que no Piauí as "discriminações" do trabalho feminino diminuíram pela ampliação das oportunidades no mercado de trabalho no setor de prestação de serviços e melhoria do nível de escolaridade.

A equação (37) também foi ajustada considerando-se a situação de domicílio (urbano ou rural) e a atividade do trabalho principal (agrícola ou não-agrícola), separadamente. Em apêndice, encontram-se as tabelas com os coeficientes das equações de regressões ajustadas para os anos de 1992, 1993 e 1995.

Os resultados, considerando a situação do domicílio urbano e rural, estão registrados na tabela 43. Ela mostra que, na situação do domicílio urbano, os fatores considerados explicam (estatisticamente) apenas 54,7\% (1992), 62,2\% (1993) e 54,0\% (1995) das variações do logaritmo do rendimento das pessoas economicamente ativas no Piauí. 
Tabela 43. Número de observações, valores de $\mathrm{F}$ e $\mathrm{R}^{2}$ e a contribuição marginal de cada fator ${ }^{(1)}$ para o modelo estimado, por situação do domicílio; Piauí- 1992, 1993 e 1995.

\begin{tabular}{|c|c|c|c|c|c|c|}
\hline \multirow[t]{2}{*}{ ESTATISTICA } & \multicolumn{3}{|c|}{ URBANO } & \multicolumn{3}{|c|}{ RURAL } \\
\hline & 1992 & 1993 & 1995 & 1992 & 1993 & 1995 \\
\hline NÚMERO DE OBSERVAÇÕES & 970 & 946 & 954 & 570 & 459 & 546 \\
\hline $\mathrm{F}^{(2)}$ & 49,6 & 65,9 & 47,4 & 13,5 & 13,4 & 13,3 \\
\hline COEFICIENTE DE DETERMINAÇÃO (\%) & 54,7 & 62,2 & 54,0 & 36,3 & 41,2 & 36,9 \\
\hline CONTRIBUIÇÃO MARGINAL & & & & & & \\
\hline sexo & 9,9 & 4,0 & 6,6 & 16,9 & 11,5 & 3,4 \\
\hline idade & 12,9 & 12,4 & 14,7 & 38,0 & 30,6 & 38,0 \\
\hline escolaridade & 15,3 & 13,4 & 24,7 & 11,9 & 13,0 & 14,1 \\
\hline posição na ocupação & 6,7 & 11,8 & 6,8 & 5,5 & 3,5 & 3,5 \\
\hline atividade principal & 5,1 & 2,9 & 5,1 & 2,2 & 4,7 & 4,9 \\
\hline horas de trabalho & 3,2 & 3,6 & 7,4 & 10,8 & 9,0 & 18,2 \\
\hline
\end{tabular}

Fonte: IBGE. Microdados das PNAD de 1992, 1993 e 1995.

(1) Contribuição marginal do fator (SSII (fator) /SSMODEL) conforme Procedure GLM/SAS, em percentual. (2) Os valores de F são estatisticamente significativos ao nivel de $1 \%$.

No meio urbano, destacam-se as contribuições, como porcentagem da parte das variações de $Y$ explicadas pelo modelo completo, da idade, com 12,9\% (1992), 12,4\% (1993) e 14,7\% (1995) e da escolaridade, com 15,3\% (1992), 13,4\% (1993) e $24,7 \%$ (1995), verificando-se o crescimento deste último fator como determinante da desigualdade no rendimento da PEA urbana piauiense, refletindo um mercado de trabalho formalizado, que exige uma maior qualificação.

No domicílio rural, os coeficientes de determinação foram $36,3 \%$ (1992), 41,2\% (1993) e 36,9\% (1995). Os fatores que mais explicam as variações no rendimento sofreram alternância entre esses anos, pois, em 1992, a idade contribui com $38,0 \%$, o sexo com 16,9\% e a escolaridade com 11,9\%. Já em 1993, a idade contribuiu com $30,6 \%$, o sexo diminui para $11,5 \%$ e a escolaridade se eleva para $13,0 \%$. Em 1995 , destacam-se a idade com $38,0 \%$, a escolaridade com $14,1 \%$ e horas de trabalho com $18,2 \%$. 
A idade aparece como o fator mais explicativo da desigualdade dos rendimentos das pessoas economicamente ativas no meio rural nos três anos, seguida das horas de trabalho, refletindo as próprias características do mercado de trabalho rural, em que as pessoas possuem baixa escolaridade.

A tabela 44 apresenta as equações ajustadas para o setor agrícola em 1992, 1993 e 1995. Observa-se que o coeficiente de determinação é 36,1\% (1992), 43,1\% (1993) e $31,9 \%$ (1995). Os valores de $\mathrm{F}$ são estatisticamente significativos ao nível de $1 \%$ nos três anos, considerando o conjunto das variáveis do modelo ajustado.

Tabela 44. Número de observações, valores de $F$ e $R^{2}$ e a contribuição marginal de cada fator ${ }^{(1)}$ para os modelos estimado, por atividade principal agrícola; Piauí- 1992, 1993 e 1995.

\begin{tabular}{c|c|c|c}
\hline ESTATISTICA & \multicolumn{3}{c}{ AGRICOLA } \\
\cline { 2 - 4 } & 1992 & 1993 & 1995 \\
\hline NƯMERO DE OBSERVAÇÕES & 534 & 398 & 441 \\
F $^{(2)}$ & 14,5 & 14,3 & 9,9 \\
COEFICIENTE DE DETERMINAÇÃO (\%) & 36,1 & 43,1 & 31,9 \\
CONTRIBUIÇÃO MARGINAL & & & \\
situação do domicilio & & 0,4 & 0,0 \\
sexo & 0,0 & 6,5 & 0,3 \\
idade & 6,8 & 37,0 & 61,9 \\
escolaridade & 55,7 & 9,3 & 5,2 \\
posição na ocupação & 5,5 & 10,2 & 10,6 \\
horas de trabalho & 4,8 & 9,3 & 17,0 \\
\hline
\end{tabular}

Fonte: IBGE. Microdados das PNAD de 1992, 1993 e 1995

(2) Contribuição marginal do fator (SSII (fator) /SSMODEL) conforme Procedure GLM/SAS, em percentual. (1) Os valores de F são estatisticamente significativos ao nivel de $1 \%$. 
A importância relativa de cada uma das variáveis na explicação dos diferenciais dos rendimentos das pessoas ocupadas na atividade agrícola no Piauí é dada pela contribuição marginal. Nesse modelo ajustado destacam-se a idade, que contribuiu com $55,7 \%$ (1993), 37,0\% (1993) e 61,9\% (1995), as horas de trabalho, com 14,0\% (1992), $9,3 \%$ (1993) e 17,0\% (1995) e a posição na ocupação, com 4,8\% (1992), 10,2\% (1993) e $10,6 \%$ (1995). Esse último fator é uma proxy da propriedade fundiária.

Calculam-se os números-índices ${ }^{36}$ proporcionais às estimativas dos diferenciais de rendimento, indicando o valor esperado do rendimento de uma dada categoria de uma dada variável, em relação ao rendimento médio da categoria eleita para base nesse fator (já considerados os efeitos das diferenças das demais variáveis analisadas) nos anos de 1992, 1993 e 1995, ou, simplesmente, o percentual de aumento no rendimento esperado da pessoa pertencente a uma categoria, em relação à categoria de referência.

Os resultados na tabela 45 apontam que o rendimento do homem tende a ser 2,1 vezes maior que o rendimento da mulher em 1992, passando para 1,6 vezes em 1995, observando-se um decréscimo nos diferenciais de rendimentos entre homens e mulheres no Piauí, devido à diminuição das "discriminações" do trabalho feminino.

\footnotetext{
${ }^{36}$ Se $\beta$ é o coeficiente estimado da equação de rendimentos, o correspondente número-índice é $100 \exp (\beta)$.
} 
Tabela 45. Números-índices do nível do rendimento estimado para as categorias dos fatores considerados no modelo de regressão; Piauí- 1992, 1993 e 1995.

\begin{tabular}{|c|c|c|c|}
\hline \multirow[b]{2}{*}{ FATORES } & \multicolumn{3}{|c|}{ ANOS } \\
\hline & 1992 & 1993 & 1995 \\
\hline \multicolumn{4}{|c|}{ SITUAÇÃO DO DOMICKLIO } \\
\hline urbano & 124 & 115 & 129 \\
\hline rural & 100 & 100 & 100 \\
\hline \multicolumn{4}{|l|}{ SEXO } \\
\hline Homem & 213 & 175 & 155 \\
\hline Mulher & 100 & 100 & 100 \\
\hline \multicolumn{4}{|l|}{ IDADE } \\
\hline 10 a 14 anos & 100 & 100 & 100 \\
\hline 15 a 17 anos & 122 & 121 & 125 \\
\hline 18 a 19 anos & 151 & 175 & 154 \\
\hline 20 a 24 anos & 163 & 191 & 161 \\
\hline 25 a 29 anos & 194 & 230 & 211 \\
\hline 30 a 39 anos & 231 & 272 & 228 \\
\hline 40 a 49 anos & 294 & 296 & 277 \\
\hline 50 a 59 anos & 338 & 364 & 283 \\
\hline 60 anos ou mais & 635 & 800 & 688 \\
\hline \multicolumn{4}{|l|}{ ESCOLARIDADE } \\
\hline sem instrução e menos de l ano & 100 & 100 & 100 \\
\hline 1 a 4 anos & 119 & 125 & 119 \\
\hline 5 a 8 anos & 149 & 169 & 138 \\
\hline 9 a 11 anos & 283 & 275 & 230 \\
\hline 12 anos ou mais & 470 & 488 & 495 \\
\hline \multicolumn{4}{|l|}{ POSIÇÃO NA OCUPAÇÃO } \\
\hline empregado com carteira assinada & 100 & 100 & 100 \\
\hline funcionário publico. & 100 & 120 & 119 \\
\hline outros empregados & 56 & 56 & 78 \\
\hline domésticá & 50 & 40 & 66 \\
\hline conta-própria & 70 & 70 & 80 \\
\hline empregadores & 138 & 143 & 172 \\
\hline \multicolumn{4}{|l|}{ ATIVIDADE PRINCIPAL } \\
\hline agrícola & 100 & 100 & 100 \\
\hline não-agricola & 167 & 157 & 178 \\
\hline \multicolumn{4}{|l|}{ HORAS DE TRABALHO } \\
\hline até 14 & 100 & 100 & 100 \\
\hline 15 a 39 & 182 & 131 & 147 \\
\hline 40 a 44 & 226 & 177 & 178 \\
\hline 45 a 48 & 237 & 194 & 209 \\
\hline 49 ou mais & 275 & 227 & 259 \\
\hline
\end{tabular}

Fonte: IBGE. Microdados das PNAD de 1992, 1993 e 1995

(1) Resultados a partir do Procedure GLM/SAS.

Considerando-se as pessoas economicamente ativas no domicílio urbano, verifica-se, na tabela 46, que a tendência foi também de diminuição dos diferenciais de rendimentos entre homens e mulheres. Em 1992, o rendimento do homem tende a ser 2,0 vezes maior do que o da mulher. Já em 1995 é de apenas 1,6 vezes. 
Tabela 46. Números-índices do nível do rendimento estimado para as categorias dos fatores considerados no modelo de regressão, conforme situação do domicilio urbano; Piauí- 1992, 1993 e 1995.

\begin{tabular}{|c|c|c|c|}
\hline \multirow[b]{2}{*}{ FATORES } & \multicolumn{3}{|c|}{ ANOS } \\
\hline & 1992 & 1993 & 1995 \\
\hline \multicolumn{4}{|l|}{ SEXO } \\
\hline Homem & 201 & 162 & 159 \\
\hline Mulher & 100 & 100 & 100 \\
\hline \multicolumn{4}{|l|}{ DADE } \\
\hline 10 a 14 anos & 100 & 100 & 100 \\
\hline 15 a 17 anos & 106 & 118 & 128 \\
\hline 18 a 19 anos & 140 & 175 & 153 \\
\hline 20 a 24 anos & 160 & 192 & 168 \\
\hline 25 a 29 anos & 185 & 247 & 224 \\
\hline 30 a 39 anos & 216 & 276 & 247 \\
\hline 40 a 49 anos & 276 & 298 & 305 \\
\hline 50 a 59 anos & 299 & 345 & 323 \\
\hline 60 anos ou mais & 591 & 800 & 588 \\
\hline \multicolumn{4}{|l|}{ ESCOLARIDADE } \\
\hline sem instrução e menos de 1 ano & 100 & 100 & 100 \\
\hline I a 4 anos & 116 & 129 & 126 \\
\hline 5 a 8 anos & 144 & 178 & 150 \\
\hline 9 a 11 anos & 256 & 272 & 241 \\
\hline 12 anos ou mais & 409 & 445 & 480 \\
\hline \multicolumn{4}{|c|}{ POSIÇÃO NA OCUPAÇÃo } \\
\hline empregado com carteira. Assinada & 100 & 100 & 100 \\
\hline funcionário público. & 91 & 114 & 119 \\
\hline outros empregados. & 51 & 51 & 73 \\
\hline doméstica & 43 & 35 & 68 \\
\hline conta-própria & 68 & 67 & 89 \\
\hline empregadores & 130 & 165 & 200 \\
\hline \multicolumn{4}{|l|}{ ATIVIDADE PRINCIPAL } \\
\hline agrícola & 100 & 100 & 100 \\
\hline não-agricola & 208 & 181 & 199 \\
\hline \multicolumn{4}{|l|}{ HORAS DE TRABALHO } \\
\hline até 14 & 100 & 100 & 100 \\
\hline 15 a 39 & 208 & 143 & 181 \\
\hline 40 a 44 & 263 & 186 & 223 \\
\hline 45 a 48 & 261 & 192 & 241 \\
\hline 49 ou mais & 272 & 229 & 279 \\
\hline
\end{tabular}

Fonte: IBGE. Microdados das PNAD de 1992, 1993 e 1995.

(1) Resultados a partir do Procedure GLM/SAS.

No domicílio rural (tabela 47), o rendimento do homem é 2,5 vezes maior que o da mulher em 1992 e 1,47 em 1995 e na atividade agrícola (tabela 48) é 2,0 vezes em 1992 e $1,1 \mathrm{em} 1995$. 
Tabela 47. Números-índices do nível do rendimento estimado para as categorias dos fatores considerados no modelo de regressão, conforme situação do domicílio rural; Piaui- 1992, 1993 e 1995.

\begin{tabular}{|c|c|c|c|}
\hline \multirow[b]{2}{*}{ FATORES } & \multicolumn{3}{|c|}{ ANOS } \\
\hline & 1992 & 1993 & 1995 \\
\hline \multicolumn{4}{|l|}{ SEXO } \\
\hline Homem & 251 & 211 & 147 \\
\hline Mulher & 100 & 100 & 100 \\
\hline \multicolumn{4}{|l|}{ IDADE } \\
\hline 10 a 14 anos & 100 & 100 & 100 \\
\hline 15 a 17 anos & 183 & 130 & 122 \\
\hline 18 a 19 anos & 200 & 159 & 151 \\
\hline 20 a 24 anos & 179 & 164 & 148 \\
\hline 25 a 29 anos & 239 & 157 & 185 \\
\hline 30 a 39 anos & 274 & 218 & 194 \\
\hline 40 a 49 anos & 353 & 223 & 224 \\
\hline 50 a 59 anos & 459 & 319 & 238 \\
\hline 60 anos ou mais & 835 & 693 & 713 \\
\hline \multicolumn{4}{|c|}{ ESCOLARIDADE } \\
\hline sem instrução e menos de 1 ano & 100 & 100 & 100 \\
\hline 1 a 4 anos & 121 & 127 & 109 \\
\hline 5 a 8 anos & 125 & 145 & 104 \\
\hline 9 a 11 anos & 364 & 203 & 205 \\
\hline 12 anos ou mais & 1.127 & 1.929 & 1.188 \\
\hline \multicolumn{4}{|c|}{ POSIÇÃO NA OCUPAÇÃO } \\
\hline empregado com carteira assinada & 100 & 100 & 100 \\
\hline funcionário público. & 178 & 114 & 101 \\
\hline outros empregados. & 82 & 71 & 86 \\
\hline doméstica & 133 & 65 & 76 \\
\hline conta-própria & 92 & 49 & 68 \\
\hline empregadores & 175 & 118 & 105 \\
\hline \multicolumn{4}{|c|}{ ATIVIDADE PRINCIPAL } \\
\hline agrícola & 100 & 100 & 100 \\
\hline não-agricola & 139 & 156 & 153 \\
\hline \multicolumn{4}{|c|}{ HORAS DE TRABALHO } \\
\hline ate 14 & 100 & 100 & 100 \\
\hline 15 a 39 & 137 & 102 & 106 \\
\hline 40 a 44 & 153 & 157 & 119 \\
\hline 45 a 48 & 173 & 189 & 171 \\
\hline 49 ou mais & 248 & 221 & 221 \\
\hline
\end{tabular}

Fonte: IBGE. Microdados das PNAD de 1992, 1993 e 1995.

(1) Resultados a partir do Procedure GLM/SAS. 
Tabela 48. Números-índices do nível do rendimento estimado para as categorias dos fatores considerados no modelo de regressão, conforme atividade principal agrícola; Piauí- 1992, 1993 e 1995.

\begin{tabular}{|c|c|c|c|}
\hline \multirow[b]{2}{*}{ FATORES } & \multicolumn{3}{|c|}{ ANOS } \\
\hline & 1992 & 1993 & 1995 \\
\hline \multicolumn{4}{|c|}{ SITUAÇÃO DO DOMICÍLIO } \\
\hline urbano & 100 & 90 & 102 \\
\hline rural & 100 & 100 & 100 \\
\hline \multicolumn{4}{|l|}{ SEXO } \\
\hline Homem & 195 & 197 & 112 \\
\hline Mulher & 100 & 100 & 100 \\
\hline \multicolumn{4}{|l|}{ IDADE } \\
\hline 10 a 14 anos & 100 & 100 & 100 \\
\hline 15 a 17 anos & 149 & 124 & 112 \\
\hline 18 a 19 anos & 199 & 174 & 117 \\
\hline 20 a 24 anos & 161 & 153 & 114 \\
\hline 25 a 29 anos & 235 & 214 & 141 \\
\hline 30 a 39 anos & 250 & 244 & 154 \\
\hline 40 a 49 anos & 400 & 230 & 212 \\
\hline 50 a 59 anos & 406 & 299 & 230 \\
\hline 60 anos ou mais & 906 & 768 & 576 \\
\hline \multicolumn{4}{|l|}{ ESCOLARIDADE } \\
\hline sem instrução e menos de 1 ano & 100 & 100 & 100 \\
\hline 1 a 4 anos & 120 & 119 & 119 \\
\hline 5 a 8 anos & 114 & 166 & 119 \\
\hline 9 anos ou mais & 431 & 719 & 268 \\
\hline \multicolumn{4}{|c|}{ POSIÇÃO NA OCUPAÇ̃̃O } \\
\hline empregado com .carteira assinada & 100 & 100 & 100 \\
\hline outros empregados. & 44 & 49 & 101 \\
\hline conta-própria & 42 & 44 & 64 \\
\hline empregadores & 81 & 100 & 115 \\
\hline \multicolumn{4}{|l|}{ HORAS DE TRABALHO } \\
\hline até 14 & 100 & 100 & 100 \\
\hline 15 a 39 & 178 & 49 & 75 \\
\hline 40 a 44 & 178 & 43 & 68 \\
\hline 45 a 48 & 316 & 53 & 96 \\
\hline 49 ou mais & 316 & 74 & 123 \\
\hline
\end{tabular}

Fonte: IBGE. Microdados das PNAD de 1992, 1993 e 1995.

(1) Resultados a partir do Procedure GLM/SAS

Em sintese, os diferenciais de rendimentos entre homens e mulheres no Piauí diminuem nos anos 90 , tanto a nível geral quanto no domicilio urbano, rural e setor agrícola, sinalizando uma diminuição das discriminações do trabalho feminino.

Verifica-se que, no Estado do Piauí o rendimento esperado das pessoas economicamente ativas é máximo para aquelas com idade de 60 anos ou mais. Segundo os resultados dos estudos de Corrêa (1995) e Hoffmann (1996 e 1997) para as pessoas 
ocupadas na agricultura brasileira no período de $1981-90$ e 1995 , respectivamente, o valor esperado do rendimento é máximo para as pessoas que têm 40 a 59 anos, reduzindo-se para os que têm 60 anos ou mais. No Piauí, as pessoas com 60 anos ou mais têm rendimento esperado, em 1995, 5,9 vezes maior do que as com 10 a 14 anos no domicílio urbano, 7,1 vezes no rural e 5,8 vezes na atividade agrícola.

As tabelas anteriores mostram também que o maior nível educacional associa-se com o rendimento mais elevado. O diferencial de rendimentos entre os níveis de escolaridade são maiores no domicílio rural e na atividade agrícola, cabendo destacar que o valor esperado do rendimento de uma pessoa no meio rural, com 12 anos ou mais de estudo, tende a ser maior do que o da pessoa sem instrução em 11,3 vezes em 1992, 19,3 vezes em 1993 e 11,9 vezes em 1995.

Os diferenciais de rendimentos entre as categorias do fator posição na ocupação apontam a distância entre o rendimento do empregador (normalmente proprietário dos meios de produção), em relação ao rendimento das outras categorias. O conta-própria é a forma de inserção no mercado de trabalho predominante no Piauí, mas, ao mesmo tempo, essa categoria tende a ganhar $20,0 \%$ no geral, $11 \%$ no domicílio urbano, $32 \%$ no domicílio rural e $36 \%$ no setor agrícola menos do que o empregado assalariado com carteira assinada em 1995. É mais um indicador a esclarecer o baixo rendimento das pessoas economicamente ativas no estado.

Portanto, fatores sócio-demográficos (sexo, idade e nível educacional) e da estrutura econômica (setor de atividade e horas de trabalho) explicam, em parte, a desigualdade entre os rendimentos das pessoas economicamente ativas nos anos 90 . 


\subsection{Grau da pobreza absoluta no Estado do Piauí}

O grau da pobreza piauiense é avaliado através dos índices de pobreza que constam na tabela 49. Estes indicadores mensuram o grau da pobreza absoluta, considerando três linhas de pobreza ( $1 / 4 \mathrm{SM}, 1 / 2 \mathrm{SM}$ e $1 \mathrm{SM}$ ).

Tabela 49. Medidas de pobreza absoluta entre as pessoas economicamente ativas ${ }^{(1)} \mathrm{com}$ rendimento; Piauí -1992, 1993 e 1995.

\begin{tabular}{|c|c|c|c|c|}
\hline \multirow{2}{*}{\multicolumn{2}{|c|}{ ESTATÍSTICA }} & \multicolumn{3}{|c|}{ LINHAS DE POBREZA ${ }^{(2)}$} \\
\hline & & $1 \mathrm{SM}$ & $1 / 2 \mathrm{SM}$ & $1 / 4 \mathrm{SM}$ \\
\hline \multirow[t]{3}{*}{ Número de pobres } & 1992 & 570.031 & 366.760 & 216.518 \\
\hline & 1993 & 630.994 & 358.611 & 213.761 \\
\hline & 1995 & 566.832 & 257.367 & 116.180 \\
\hline \multirow[t]{3}{*}{ Proporção de pobres } & 1992 & 0,722 & 0,465 & 0,274 \\
\hline & 1993 & 0,711 & 0,404 & 0,241 \\
\hline & 1995 & 0,617 & 0,280 & 0,127 \\
\hline \multirow[t]{3}{*}{ Índice de Pobreza de Sen } & 1992 & 0,534 & 0,322 & 0,169 \\
\hline & 1993 & 0,502 & 0,275 & 0,140 \\
\hline & 1995 & 0,389 & 0,172 & 0,071 \\
\hline \multirow[t]{3}{*}{$I^{(3)}$} & 1992 & 0,573 & 0,542 & 0,465 \\
\hline & 1993 & 0,546 & 0,532 & 0,436 \\
\hline & 1995 & 0,482 & 0,468 & 0,419 \\
\hline \multirow[t]{3}{*}{$\varphi^{(4)}$} & 1992 & 0,300 & 0,169 & 0,079 \\
\hline & 1993 & 0,267 & 0,142 & 0,061 \\
\hline & 1995 & 0,185 & 0,079 & 0,030 \\
\hline
\end{tabular}

Fonte: IBGE. Microdados das PNAD de 1992, 1993 e 1995.

(1) O total da PEA é 789.498 (1992), 887.623 (1993) e 917.977 (1995). (2) Linha de pobreza com valor real igual ao maior salário mínimo de agosto de 1980. Essa linha de pobreza em moeda corrente é Cr\$ $651218 \mathrm{em} 1992,13057,63 \mathrm{em} 1993$ e 143,15 em 1995 (sempre em setembro, que é o mês de referência das PNAD). (3) Razão de insuficiência de renda (I). (4) Indice de Foster, Greer e Thorbecke.

Observa-se que o número de pobres decresce entre 1992 e 1995, para as linhas de pobreza de $1 / 2 \mathrm{SM} \mathrm{e}^{1 / 4} \mathrm{SM}$. Para linha de pobreza de $1 \mathrm{SM}$, o número de pobres se eleva 
de 1992 a 1993 e decresce de 1993 a 1995, sendo um total de 566.832 pobres em 1995, número inferior a 570.031 pobres em 1992.

Pode-se justificar a diminuição do número de pobres com linha de pobreza de 1 SM pela diminuição do efeito da inflação sobre o salário mínimo, vez que o SM teve aumento de $42,86 \%$ em maio/1995, permitindo ao governo contabilizar ganhos na queda do nível da pobreza sem ter nenhum plano de combate à pobreza.

Por outro lado, a proporção de pobres foi sempre decrescente em todas as linhas de pobreza, sendo esse decréscimo maior na linha de pobreza de 1/4 SM. Na linha de pobreza de 1 SM foi de -1,5\%, entre 1992 e 1993 e - -13,2\% entre 1993 e 1995.

A relação entre a insuficiência de renda e a renda total $(\mathrm{r} \%)$ fornece o percentual da renda total cuja redistribuição seria necessária para eliminar a pobreza absoluta. Admitindo-se a linha de pobreza de $1 \mathrm{SM}$, a relação entre a insuficiência de renda e a renda total (r\%) é de 37,7\% em 1992, 31,6\% em 1993 e 20,0\% em 1995, significando que se precisa redistribuir em torno de $30 \%$ da renda total gerada pela PEA para elevar o rendimento de todos os pobres no Piauí até a linha de pobreza.

A figura 30 representa a proporção de pobres entre a PEA com rendimento nos anos de 1992, 1993 e 1995, verificando-se o contínuo decréscimo da pobreza piauiense. A taxa de variação da proporção de pobres no Piauí foi de $-1,5 \%$ no período de 1992 a 1993 e -13,3\% de 1993 a 1995 para uma linha de pobreza de 1 SM. No Nordeste ocorre crescimento da proporção de pobres de 3,1\% no período de 1992 a 1993 e diminuição a uma taxa de $-17,7 \%$, superior à do Piauí, de 1993 a 1995. 


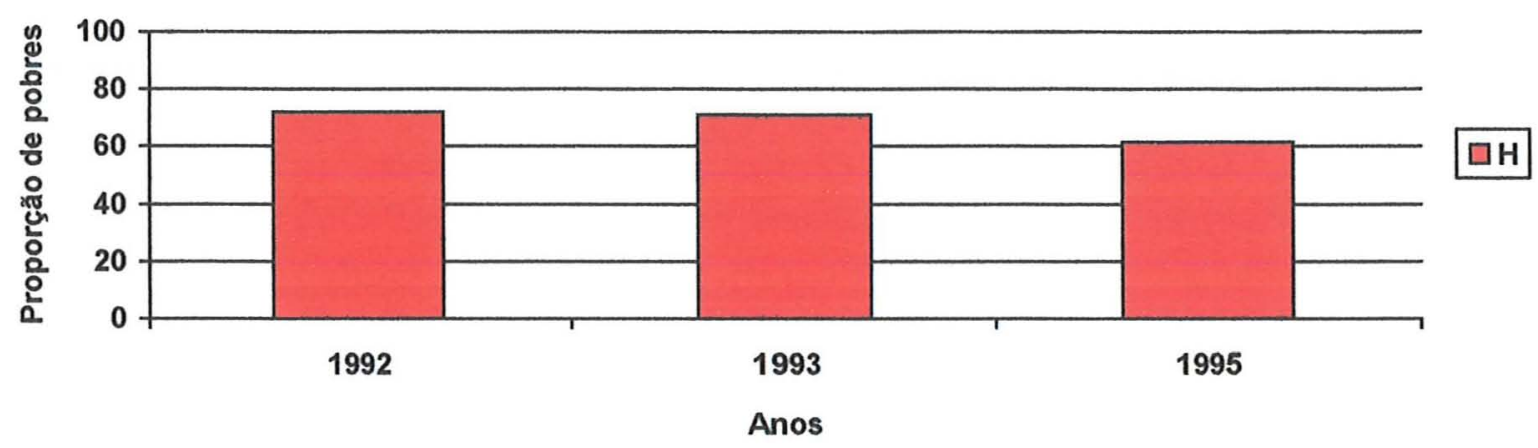

Figura 30. Proporção de pobres $(\mathrm{H})$ entre as pessoas economicamente ativas com rendimento; Piauí;1992, 1993 e 1995.

As tabelas 50 e 51 apresentam as medidas de pobreza absoluta, conforme o domicílio urbano e rural, respectivamente. Todos os indicadores apontam que a pobreza é mais acentuada no meio rural que no urbano, o que decorre das próprias diferenciações sócio-demográficas e produtivas entre essas duas áreas. 
Tabela 50. Pobreza absoluta entre as pessoas economicamente ativas com rendimento ${ }^{(1)}$ no domicílio urbano; Piauí -1992, 1993 e 1995.

\begin{tabular}{|c|c|c|c|c|}
\hline \multirow{2}{*}{\multicolumn{2}{|c|}{ ESTATÍSTICA }} & \multicolumn{3}{|c|}{ LINHAS DE POBREZA $^{(2)}$} \\
\hline & & $1 \mathrm{SM}$ & $1 / 2 \mathrm{SM}$ & $1 / 4 \mathrm{SM}$ \\
\hline \multirow[t]{3}{*}{ Número de pobres } & 1992 & 322.087 & 187.554 & 105.069 \\
\hline & 1993 & 343.438 & 183.379 & 109.059 \\
\hline & 1995 & 281.328 & 107.843 & 38.553 \\
\hline \multirow[t]{3}{*}{ Proporção de pobres } & 1992 & 0,657 & 0,382 & 0,214 \\
\hline & 1993 & 0,627 & 0,335 & 0,199 \\
\hline & 1995 & 0,508 & 0,195 & 0,070 \\
\hline \multirow[t]{3}{*}{ Índice de Pobreza de Sem } & 1992 & 0,534 & 0,322 & 0,169 \\
\hline & 1993 & 0,431 & 0,229 & 0,116 \\
\hline & 1995 & 0,292 & 0,105 & 0,032 \\
\hline \multirow[t]{3}{*}{$I^{(3)}$} & 1992 & 0,532 & 0,524 & 0,457 \\
\hline & 1993 & 0,525 & 0,535 & 0,444 \\
\hline & 1995 & 0,442 & 0,413 & 0,343 \\
\hline \multirow[t]{3}{*}{$\varphi^{(4)}$} & 1992 & 0,300 & 0,169 & 0,079 \\
\hline & 1993 & 0,224 & 0,118 & 0,051 \\
\hline & 1995 & 0,128 & 0,043 & 0,011 \\
\hline
\end{tabular}

Fonte: IBGE. Microdados das PNAD de 1992, 1993 e 1995.

(1) O total da PEA urbana é 490.494 (1992), 547.433 (1993) e 553.284 (1995). (2) Linha de pobreza com valor real igual ao maior salário minimo de agosto de 1980. Essa linha de pobreza em moeda corrente é Cr\$651218 em 1992, 13057,63 em 1993 e 143,15 em 1995 (sempre em setembro, que é o mês de referência das PNAD). (3) Razão de insuficiência de renda (I). (4) Índice de Foster, Greer e Thorbecke. 
Tabela 51. Pobreza absoluta entre as pessoas economicamente ativas com rendimento no domicílio rural ${ }^{(1)}$; Piauí -1992, 1993 e 1995.

\begin{tabular}{lc|c|c|c}
\hline \multirow{2}{*}{ ESTATISTICA } & & \multicolumn{3}{|c}{ LINHAS DE POBREZ $^{(2)}$} \\
\cline { 3 - 5 } & 1992 & 247.944 & 179.206 & $1 / 4$ SM \\
\hline Número de pobres & 1993 & 287.556 & 175.232 & 104.702 \\
& 1995 & 285.504 & 149.524 & 77.627 \\
Proporção de pobres & 1992 & 0,829 & 0,599 & 0,373 \\
& 1993 & 0,845 & 0,515 & 0,307 \\
& 1995 & 0,783 & 0,410 & 0,213 \\
Índice de Pobreza de Sen & 1992 & 0,649 & & \\
& 1993 & 0,613 & 0,560 & 0,472 \\
& 1995 & 0,532 & 0,349 & 0,177 \\
& & & 0,270 & 0,127 \\
$I^{(3)}$ & 1992 & 0,627 & 0,560 & 0,472 \\
& 1993 & 0,571 & 0,529 & 0,427 \\
& 1995 & 0,522 & 0,508 & 0,457 \\
& & & & \\
$\varphi^{(4)}$ & 1992 & 0,391 & 0,229 & 0,109 \\
& 1993 & 0,337 & 0,179 & 0,077 \\
& 1995 & 0,272 & 0,134 & 0,057 \\
\hline
\end{tabular}

Fonte: IBGE. Microdados das PNAD de 1992, 1993 e 1995.

(1) O total da PEA rural é 299.004 (1992), 340.190 (1993) e 364.693 (1995). (2) Linha de pobreza com valor real igual ao maior salário minimo de agosto de 1980. Essa linha de pobreza em moeda corrente é Cr\$651218 em 1992, 13057,63 em 1993 e 143,15 em 1995 (sempre em setembro, que é o mês de referência das PNAD). (3) Razão de insuficiência de renda (1). (4) Indice de Foster, Greer e Thorbecke.

Na zona urbana, com as linhas de pobreza de $1 / 2$ e $1 / 4$ SM, a proporção de pobres é pequena se comparada com a da zona rural. Com a linha de pobreza de $1 \mathrm{SM}$, a proporção de pobres rural é maior que a de pobres urbana, 1,26 vezes em 1992, 1,34 em 1993 e 1,54 em 1995, mostrando que o decréscimo na proporção de pobres é maior no domicílio urbano.

Registra-se que essa proporção de pobres diminuiu em $22,7 \%$ na zona urbana e em 5,6\% na zona rural de 1992 a 1995. E, considerando-se a linha de pobreza de 1 SM, a insuficiência de renda como porcentagem da renda total é de $25,3 \%$ em $1992,21,6 \%$ 
em 1993 e 12,0\% em 1995, no domicílio urbano, e 81,6\% em 1992, 62,5\% em 1993 e $44,6 \%$ em 1995 , no rural.

Pode-se inferir, a partir dos dados analisados, que o efeito da redução inflacionária sobre a pobreza se reflete com maior intensidade no setor urbano, porque a cobertura do salário mínimo é maior, permitindo às pessoas economicamente ativas ultrapassarem a linha de pobreza. O número de pessoas pobres com domicílio urbano é, inclusive, 1,29 vezes maior que o número de pobres com domicílio rural em 1992, com linha de pobreza de 1 SM. Em 1995, o número de pessoas pobres com domicilio rural fica 1,01 vezes maior que os com domicílio urbano, considerando a mesma linha de pobreza.

No Piauí, as pessoas economicamente ativas que residem no domicílio rural exercem atividades, basicamente, agrícolas, e as que residem no domicílio urbano, atividades não-agrícolas. De 1992 a 1995, a PEA em situação de domicílio rural em atividades não-agrícolas obteve crescimento de $11,8 \%$ e as em atividades agrícola decréscimo de 3,9\%. Essa é uma indicação de que o crescimento da ocupação em atividade não-agrícola no meio rural também vem se manifestando no campo piauiense, que passa a ter, nessas atividades, uma fonte significativa de renda para a PEA.

A figura 31 mostra que a proporção de pobres vem decrescendo nos anos 90 , tanto no domicílio urbano quanto no rural. 


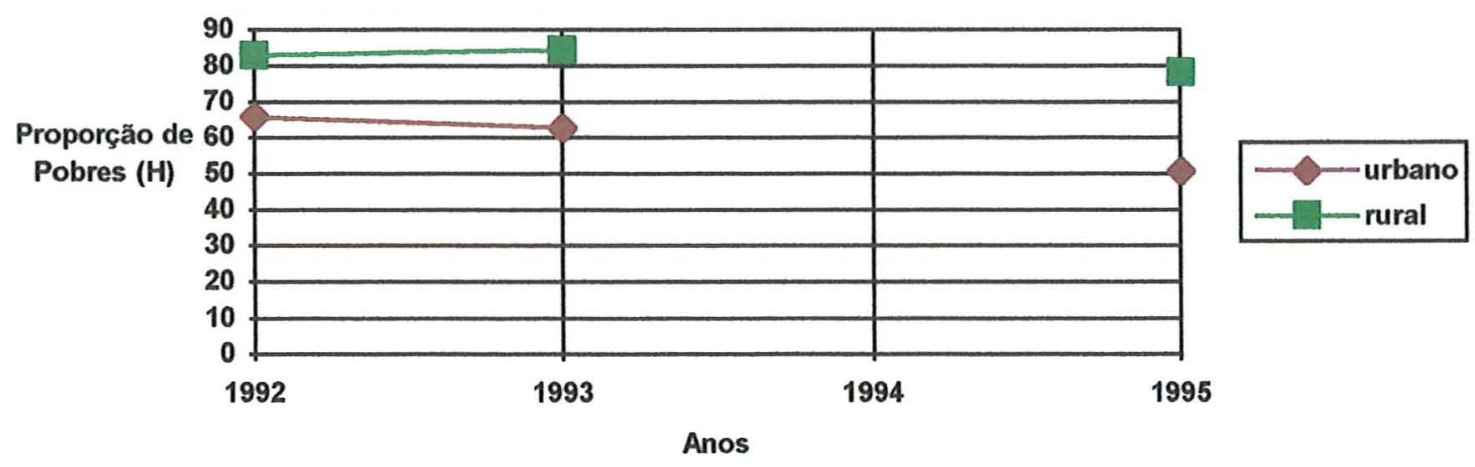

Figura 31. Proporção de pobres $(\mathrm{H})$ entre as pessoas economicamente ativas, conforme situação do domicílio; Piauí -1992, 1993 e 1995.

A tabela 52 mostra as medidas de pobreza para três linhas de pobreza, $1 \mathrm{SM}, 1 / 2$ SM e 1/4 SM, considerando a atividade agrícola O número de observações é 581 (1992), 602 (1993) e 634 (1995), correspondendo a 285.261, 326.616 e 330.305 pessoas ocupadas na atividade agrícola. Nota-se que as medidas de pobreza, no período de 1992 a 1995, apresentam diminuição, revelando decréscimo do grau da pobreza absoluta na agricultura piauiense. 
Tabela 52. Pobreza absoluta entre as pessoas ocupadas com rendimento na atividade agrícola $^{(1)}$; Piauí $-1992,1993$ e 1995.

\begin{tabular}{lcc|c|c}
\hline \multirow{2}{*}{ ESTATÍSTICA } & & \multicolumn{3}{c}{ LINHAS DE POBREZA $^{(2)}$} \\
\cline { 3 - 5 } & 1992 & 232.727 & 168.899 & 103.596 \\
\hline Número de pobres & 1993 & 278.869 & 167.092 & 100.367 \\
& 1995 & 264.661 & 128.163 & 66.166 \\
\multirow{2}{*}{ Proporção de pobres } & 1992 & 0,816 & 0,592 & 0,363 \\
& 1993 & 0,854 & 0,512 & 0,307 \\
& 1995 & 0,801 & 0,388 & 0,200 \\
Indice de Pobreza de Sen & & & & \\
& 1992 & 0,635 & 0,411 & 0,214 \\
& 1993 & 0,614 & 0,344 & 0,170 \\
& 1995 & 0,528 & 0,257 & 0,123 \\
$I^{(3)}$ & & & & \\
& 1992 & 0,626 & 0,551 & 0,443 \\
& 1993 & 0,564 & 0,529 & 0,409 \\
& 1995 & 0,500 & 0,508 & 0,470 \\
& & & & \\
& 1992 & 0,381 & 0,217 & 0,095 \\
& 1993 & 0,335 & 0,175 & 0,071 \\
& 1995 & 0,264 & 0,128 & 0,057 \\
\hline
\end{tabular}

Fonte: IBGE: Microdados das PNAD de 1992, 1993 e 1995.

(1) O total das pessoas ocupadas na atividade agricola è 285.261(1992), 326.616 (1993) e 330.305 (1995). (2) Linha de pobreza com valor real igual ao maior salário mínimo de agosto de 1980. Essa linha de pobreza em moeda corrente é Cr\$ 651218 em 1992, 13057,63 em 1993 e 143,15 em 1995 (sempre em setembro, que é o mês de referência das PNAD). (3) Razão de insuficiência de renda (I). (4) f́ndice de Foster, Greer e Thorbecke.

A insuficiência de renda como porcentagem da renda total é de $55,2 \%$ para as pessoas ocupadas em atividade agrícola em 1995, considerando a linha de pobreza de 1 $S M$. Isso significa que é preciso redistribuir em torno de $50 \%$ da renda gerada para eliminar a pobreza absoluta. 


\subsubsection{Fatores contributivos da pobreza piauiense}

Os indicadores na tabela 53 mostram que a contribuição do domicílio urbano para a pobreza piauiense foi de $50,7 \%$ (1992), 51,7\% (1993) e 41,6\% em 1995 . O domicílio rural contribuiu em 49,3\% (1992) e 48,3\% (1993), crescendo o percentual para 58,4\% em 1995, apesar do decréscimo da proporção de pobres. Este quadro revela que a redução da inflação atinge com maior intensidade o rendimento das pessoas no domicílio urbano.

Tabela 53. Decomposição da pobreza, considerando as pessoas economicamente ativas com rendimento, por situação do domicílio; Piauí - 1992, 1993 e 1995.

\begin{tabular}{|c|c|c|c|c|c|c|c|}
\hline \multicolumn{2}{|c|}{$\begin{array}{l}\text { Situação do } \\
\text { domicílio }\end{array}$} & \multirow{2}{*}{$\begin{array}{c}\begin{array}{c}\text { número de } \\
\text { pessoas }\end{array} \\
490.494\end{array}$} & \multirow{2}{*}{$\begin{array}{c}\begin{array}{c}\text { número de } \\
\text { pobres }\end{array} \\
322.087\end{array}$} & \multirow{2}{*}{$\begin{array}{l}\text { indice de } \\
\text { FGT } \\
(\varphi) \\
0,244\end{array}$} & \multirow{2}{*}{$\begin{array}{c}\begin{array}{c}\text { contribuição no } \\
\text { total da pobreza } \\
(\%)\end{array} \\
50,7\end{array}$} & \multirow{2}{*}{$\frac{\begin{array}{c}\text { renda média } \\
\text { do pobre }\end{array}}{0,47}$} & \multirow{2}{*}{$\begin{array}{c}\begin{array}{c}\text { proporção de } \\
\text { pobres em cada } \\
\text { grupo }\end{array} \\
0,657\end{array}$} \\
\hline urbano & 1992 & & & & & & \\
\hline & 1993 & 547.433 & 343.438 & 0,224 & 51,7 & 0,48 & 0,627 \\
\hline & 1995 & 553.284 & 281.328 & 0,128 & 41,6 & 0,56 & 0,508 \\
\hline \multirow[t]{3}{*}{ rural } & 1992 & 299.004 & 247.944 & 0,391 & 49,3 & 0,37 & 0,829 \\
\hline & 1993 & 340.190 & 287.556 & 0,337 & 48,3 & 0,43 & 0,845 \\
\hline & 1995 & 364.693 & 285.504 & 0,272 & 58,4 & 0,48 & 0,783 \\
\hline \multirow[t]{3}{*}{ total } & 1992 & 789.498 & 570.031 & 0,300 & 100,0 & 0,43 & 0,722 \\
\hline & 1993 & 887.623 & 630.994 & 0,267 & 100,0 & 0,45 & 0,711 \\
\hline & 1995 & 917.977 & 566.832 & 0,185 & 100,0 & 0,52 & 0,617 \\
\hline
\end{tabular}

Fonte: IBGE. Microdados das PNAD 1992, 1993 e 1995.

(1) Valores reais em unidades iguais ao maior salário mínimo de agosto de 1980, de acordo com o INPC restrito. Este valor em

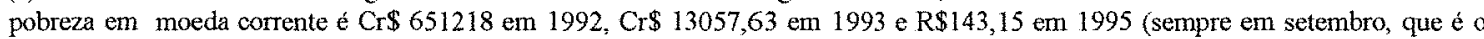
mês de referência das PNAD).

A figura 32 apresenta a contribuição percentual das pessoas economicamente ativas, que residem no domicílio urbano e rural no total da pobreza. 


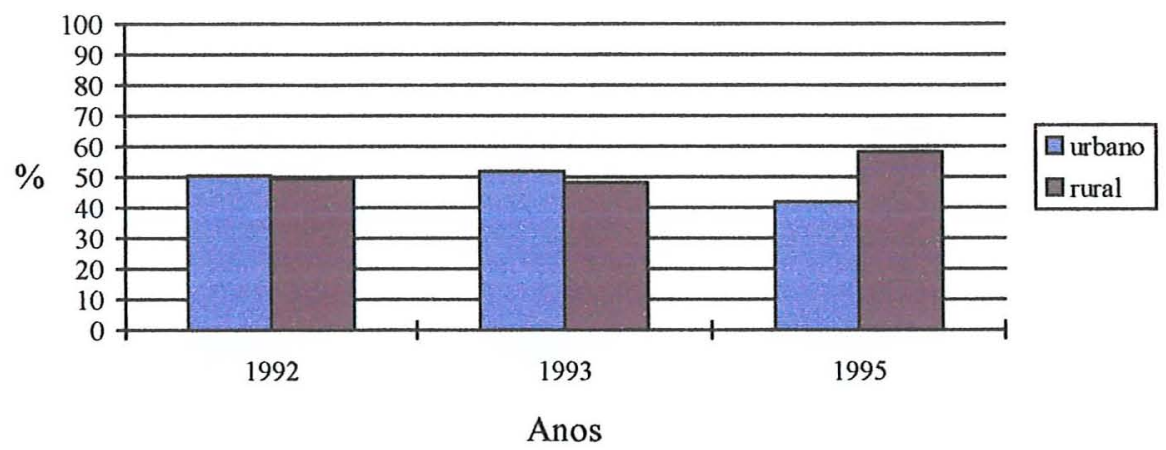

Figura 32. Contribuição das pessoas economicamente ativas com domicílio urbano e rural no total da pobreza (em percentual); Piauí - 1992, 1993 e 1995

As tabelas 54, 55, 56 e 57 apresentam os resultados da decomposição da pobreza para as pessoas ocupadas na atividade agrícola por faixa etária, escolaridade, sexo e formas de inserção no mercado de trabalho. O grupo etário de 30 a 49 anos contribuiu com $40,9 \%$ para a pobreza rural, embora represente apenas $32,8 \%$ das pessoas ocupadas na agricultura. Como é esperado, as pessoas sem instrução e com menos de 1 ano de estudo contribuíram com $54,4 \%$, os homens com $82,5 \%$ e o grupo dos conta-própria com $72,7 \%$. Vale ressaltar que essa última contribuição é superestimada pela não inclusão do valor da produção para autoconsumo.

Nos dados sobre renda na atividade agrícola não é contabilizado o valor da produção para autoconsumo, tornando-se necessário verificar sua ordem de grandeza, porque esse valor não é desprezível, como afirmou Langoni (1973) na análise do Brasil. Mas, em posição contrária, Fishlow e Meesook (1972) mostraram que o valor é significativo.

Hoffmann (1988) relaciona as informações sobre o valor da produção e valor das vendas de produtos vegetais e animais, calculando a diferença entre esses valores e obtendo uma indicação sobre a ordem de grandeza da produção para autoconsumo no 
Piauí, em 1980, de 37,7\% do valor da produção agropecuária. No Brasil essa porcentagem é de 14,0\%. Realizando-se o mesmo cálculo para os dados do Censo Agropecuário de 1985 e 1995-96 no Piauí, obtém-se uma ordem de grandeza para produção de autoconsumo em termos de proporção do valor da produção agropecuária de $32,5 \%$ (1985) e $33,8 \%$ (1995-96).

Tabela 54. Decomposição da pobreza, considerando as pessoas economicamente ativas com rendimento e ocupadas em atividade agrícola, por faixa etária; Piauí1995 .

\begin{tabular}{l|c|c|c|c|c|c}
\hline FAIXA ETÁRIA & $\begin{array}{c}\text { Número } \\
\text { de pessoas }\end{array}$ & $\begin{array}{c}\text { Número de } \\
\text { pobres }\end{array}$ & $\begin{array}{c}\text { Índice } \\
\text { de FGT } \\
(\varphi)\end{array}$ & $\begin{array}{c}\text { Contribuição no } \\
\text { total da pobreza } \\
(\%)\end{array}$ & $\begin{array}{c}\text { Renda média } \\
\text { do pobre }\end{array}$ & $\begin{array}{c}\text { Proporção de } \\
\text { pobres em cada } \\
\text { grupo }\end{array}$ \\
\hline 10 a 29 anos & 81.273 & 76.063 & 0,406 & 38,0 & 0,39 & 0,936 \\
30 a 49 anos & 108.366 & 91.695 & 0,327 & 40,9 & 0,44 & 0,846 \\
50 anos ou mais & 140.666 & 96.903 & 0,130 & 21,1 & 0,65 & 0,689 \\
total & 330.305 & 264.661 & 0,263 & 100,0 & 0,50 & 0,801 \\
\hline
\end{tabular}

Fonte: IBGE. Microdados da PNAD de 1995.

(1) Valores reais em unidades iguais ao maior salário mínimo de agosto de 1980, de acordo com o INPC restrito. Este valor em pobreza em moeda corrente é $\mathrm{R} \$ 143,15$ em 1995 (sempre em setembro, que é o mês de referência da PNAD).

Tabela 55. Decomposição da pobreza, considerando as pessoas economicamente ativas com rendimento e ocupadas em atividade agrícola, por nível de escolaridade; Piauí- 1995.

\begin{tabular}{l|r|r|c|c|c|c}
\hline ANOS DE ESTUDO & $\begin{array}{c}\text { Número de } \\
\text { pessoas }\end{array}$ & $\begin{array}{c}\text { Número } \\
\text { de } \\
\text { pobres }\end{array}$ & $\begin{array}{c}\text { Indice } \\
\text { de FGT } \\
(\varphi)\end{array}$ & $\begin{array}{c}\text { Contribuição no } \\
\text { total da pobreza } \\
(\%)\end{array}$ & $\begin{array}{c}\text { Renda } \\
\text { média do } \\
\text { pobre }\end{array}$ & $\begin{array}{c}\text { Proporção de } \\
\text { pobres em cada } \\
\text { grupo }\end{array}$ \\
\hline s/instrução/menos 1 ano & 203.704 & 163.589 & 0,232 & 54,4 & 0,54 & 0,803 \\
1 a 4 anos & 111.492 & 89.610 & 0,314 & 40,4 & 0,44 & 0,804 \\
5 a 8 anos & 10.420 & 9.378 & 0,385 & 4,6 & 0,37 & 0,900 \\
9 anos ou mais & 4.689 & 2.084 & 0,092 & 0,6 & 0,67 & 0,444 \\
total & 330.305 & 264.661 & 0,263 & 100,0 & 0,50 & 0,801 \\
\hline
\end{tabular}

Fonte: IBGE. Microdados da PNAD de 1995

(1) Valores reais em unidades iguais ao maior salário minimo de agosto de 1980 , de acordo com o INPC restrito. Este valor em pobreza em moeda corrente é R\$ 143,15 em 1995 (sempre em setembro, que é o mês de referência da PNAD). 
Tabela 56. Decomposição da pobreza, considerando as pessoas economicamente ativas com rendimento e ocupadas em atividade agrícola, por sexo; Piauí- 1995.

\begin{tabular}{c|c|c|c|c|c|c}
\hline SEXO & $\begin{array}{c}\text { Número de } \\
\text { pessoas }\end{array}$ & $\begin{array}{c}\text { Número de } \\
\text { pobres }\end{array}$ & $\begin{array}{c}\text { Indice de } \\
\text { FGT }(\varphi)\end{array}$ & $\begin{array}{c}\text { Contribuição no } \\
\text { total da pobreza } \\
(\%)\end{array}$ & $\begin{array}{c}\text { Renda } \\
\text { média do } \\
\text { pobre }\end{array}$ & $\begin{array}{c}\text { Proporção de } \\
\text { pobres em cada } \\
\text { grupo }\end{array}$ \\
\hline homem & 253.198 & 197.973 & 0,283 & 82,5 & 0,46 & 0,782 \\
mulher & 77.107 & 66.688 & 0,195 & 17,5 & 0,62 & 0,865 \\
total & 330.305 & 264.661 & 0,263 & 100,0 & 0,50 & 0,801 \\
\hline
\end{tabular}

Fonte: IBGE. Microdados da PNAD de 1995.

(1) Valores reais em unidades iguais ao maior salário minimo de agosto de 1980, de acordo com o INPC restrito. Este valor em pobreza em moeda corrente é $\mathrm{R} \$ 143,15$ em 1995 (sempre em setembro, que é o mês de referência da PNAD).

Tabela 57. Decomposição da pobreza, considerando as pessoas economicamente ativas com rendimento e ocupadas em atividade agrícola, por formas de inserção no mercado de trabalho; Piauí- 1995.

\begin{tabular}{l|c|c|c|c|c|c}
\hline $\begin{array}{c}\text { POSIÇÃO NA } \\
\text { OCUPAÇÃO }\end{array}$ & $\begin{array}{c}\text { Número de } \\
\text { pessoas }\end{array}$ & $\begin{array}{c}\text { Número } \\
\text { de } \\
\text { pobres }\end{array}$ & $\begin{array}{c}\text { Indice } \\
\text { de FGT } \\
(\varphi)\end{array}$ & $\begin{array}{c}\text { Contribuição no } \\
\text { total da pobreza } \\
(\%)\end{array}$ & $\begin{array}{c}\text { Renda } \\
\text { média do } \\
\text { pobre }\end{array}$ & $\begin{array}{c}\text { Proporção de } \\
\text { pobres em cada } \\
\text { grupo }\end{array}$ \\
\hline empregado carteira. assinada & 1.563 & 1.042 & 0,061 & 0,11 & 0,70 & 0,667 \\
outros empregados & 45.324 & 41.156 & 0,269 & 14 & 0,50 & 0,908 \\
conta-própria & 210.478 & 162.027 & 0,300 & 72,7 & 0,44 & 0,770 \\
empregadores & 7.815 & 2.605 & 0,092 & 0,83 & 0,56 & 0,333 \\
não remunerados & 65.125 & 57.831 & 0,163 & 12,2 & 0,65 & 0,888 \\
total & 330.305 & 264.661 & 0,263 & 100,0 & 0,49 & 0,801 \\
\hline
\end{tabular}

Fonte: IBGE. Microdados da PNAD de 1995.

(1) Valores reais em unidades iguais ao maior salário mínimo de agosto de 1980, de acordo com o INPC restrito. Este valor em pobreza em moeda corrente é R\$ 143,15 em 1995 (sempre em setembro, que é o mês de referência da PNAD).

Em síntese, a desigualdade na distribuição pessoal da renda no Piaú e a pobreza diminuem nos 90, mas continuam em níveis elevados, indicando que não basta resolver o problema da inflação, porque as causas sócio-demográficas e econômicas se mantêm após o Plano Real.

Essa afirmação é subsidiada pela análise de Márcio Pochmann (1997) ao detectar, com base em dados da Pesquisa de Emprego e Desemprego da Fundação 
Essa afirmação é subsidiada pela análise de Márcio Pochmann (1997) ao detectar, com base em dados da Pesquisa de Emprego e Desemprego da Fundação SEADE e DIEESE para algumas regiões metropolitanas, que a desigualdade voltou a aumentar desde o final de 1996, justamente porque os elementos estruturais da distribuição da renda não foram modificados com o Plano Real e que é possível existir concentração de renda, mesmo com baixa inflação (o golpe de 1964 também acabou com a inflação, modernizou a economia, mas produziu concentração de renda).

Outro aspecto considerado, pelo autor supracitado, é que o capitalismo brasileiro não promoveu suas reformas clássicas (agrária, tributária e social), comprometendo a condução da política econômica e seus efeitos sobre a distribuição da renda. Além do que não existem garantias de crescimento econômico sustentado e políticas públicas ativas, reduzindo as perspectivas do emprego, o que pode ser um sinalizador de um novo retrocesso no perfil distributivo no Brasil.

Para o Piauí, segundo os dados publicados da PNAD/96, ocorre uma ligeira diminuição da desigualdade da distribuição da renda e pobreza. Tendo em vista as regressões ajustadas para o período de 1984 a 1996 não mostrarem uma influência estatisticamente significativa da inflação sobre a desigualdade ou a pobreza no Piauí, pode-se concluir que o Plano Real não foi o único fator responsável. O processo de urbanização, do final da década de 80 , mudanças qualitativas na composição da PEA e as características da estrutura produtiva também são explicativos da diminuição da desigualdade e da pobreza.

A diminuição da desigualdade da distribuição da renda e pobreza dependem não só de uma política macroeconômica estável, mas também de reformas estruturais que sustentem uma expansão da economia baseada em investimento produtivo, gerando emprego e incentivo à educação. 


\section{CONCLUSÕES}

Os índices do IDH (IPEA, 1996) e IDS (Rodrigues, 1994a) qualificam o Estado do Piauí como de baixo nível de desenvolvimento humano e social, respectivamente. $O$ baixo valor desses índices é devido aos indicadores de renda e educação, que são os piores entre os estados nordestinos.

Os dados demográficos sobre o Piauí mostraram uma população mais urbana e mais velha em 1991, seguindo o padrão geral brasileiro. Entretanto, a população rural é ainda expressiva, em torno de $47 \%$, e a faixa etária de 0 a 24 anos, de $54,2 \%$.

Em termos econômicos, o PIB piauiense tem uma pequena participação no PIB nacional, em torno de $0,5 \%$ no período de 1985 a 1995. O PIB per capita é o menor entre os estados do Nordeste (US\$964,92 em 1995).

A pesquisa adotou como unidade de análise as pessoas economicamente ativas. A composição da PEA piauiense é utilizada para caracterizar o mercado de trabalho. Desta forma, a PEA com rendimento em 1995 se compõe em grande parte de mão-deobra masculina (63,5\%), faixa etária de 29 a 48 anos (41,9\%) e nível de escolaridade sem instrução $(33,4 \%)$, residindo em domicílio urbano $(60,4 \%)$. 
Muitas das pessoas economicamente ativas trabalham por conta-própria $(40,9 \%)$, exercendo atividades não-agrícolas $(63,9 \%)$, principalmente no comércio $(10,4 \%)$, prestação de serviços $(16,5 \%)$ e social $(12,0 \%)$. A grande maioria não contribui para Previdência $(74,4 \%)$ e recebe até 2 salários mínimos $(82,6 \%)$.

Examinaram-se quatro conjuntos de dados: primeiro os dos Censos Demográficos de 1960,1970,1980; segundo, os microdados da amostra de 0,8\% do Censo Demográfico de 1980, em meio magnético; terceiro, os dados publicados das PNAD de 1984 a 1996; e quarto, as informações individuais das PNAD de 1992, 1993 e 1995, em meio magnético.

$\mathrm{Na}$ análise da evolução da distribuição da renda e pobreza, considerando os dados censitários de 1960, 1970 e 1980, verificou-se que o crescimento econômico no Brasil de 1968 a 1973 possibilitou a elevação da renda média com aumento da desigualdade e redução da pobreza no Piauí, semelhante ao ocorrido no Nordeste e Brasil.

Entretanto, as características sócio-demográficas e produtivas do Piauí contribuíram para que o crescimento da renda média fosse superior ao da nordestina e brasileira nesses anos, com a desigualdade da distribuição da renda crescendo, também, a taxas maiores, reduzindo os efeitos positivos do aumento da renda média sobre a diminuição da pobreza.

Os fatores explicativos da distribuição da renda no Piauí foram agrupados em conjunturais, decorrentes da política econômica, e "estruturais", oriundos das características sócio-demográficas e produtivas.

A partir das informações individuais da amostra de $0,8 \%$ do Censo Demográfico de 1980, analisaram-se os condicionantes da desigualdade da distribuição da renda 
através da sua contribuição marginal. A desigualdade da distribuição da renda entre as pessoas economicamente ativas com rendimento no setor agrícola está associada ao sexo $(32,3 \%)$, à idade $(31,9 \%)$ e à posição na ocupação $(14,2 \%)$. No setor industrial, à idade $(37,7 \%)$ e ao sexo $(28,0 \%)$ e, nos serviços, à escolaridade $(29,2 \%)$, à idade $(26,2 \%)$ e ao sexo $(25,9 \%)$. Essas contribuições para as variações do rendimento refletem a composição do mercado de trabalho estadual.

A pobreza apresentou forte componente rural em 1980, visto que a maioria dos pobres residirem em domicílio rural e desenvolverem atividades agrícolas.

Analisou-se a relação funcional entre pobreza, desigualdade e renda média, verificando-se que o nível de pobreza absoluta no Piauí, de 1984 a 1996, está associado mais com as variações na renda média do que com as mudanças no grau da desigualdade da distribuição da renda.

Nos anos 90, os efeitos da estabilização de preços em virtude do Plano Real (1994) possibilitam a redução das medidas de desigualdade e pobreza no Brasil, porque cessa o imposto inflacionário, mas, mesmo assim, a desigualdade e a pobreza se mantêm em níveis elevados, apesar de mais baixos que os da década de 1980 .

Verificou-se, então, a influência da inflação na desigualdade e na pobreza no Estado do Piauí, considerando os dados publicados nas PNAD de 1984 a 1996. Os resultados das regressões apontaram que há um efeito positivo da inflação, mas não estatisticamente significativo, na desigualdade e na pobreza. Pode ser, então, que o efeito da inflação sobre a desigualdade e pobreza se manifeste por meio do efeito da inflação sobre a renda média.

A estabilidade econômica põe, novamente, em evidência, a desigualdade e a pobreza como fenômenos "estruturais". O Piauí se coloca numa posição de constante 
atraso em termos produtivos em relação ao Brasil, de forma que a insuficiência de renda se apresenta como o problema mais grave, principalmente no campo.

A análise dos dados individuais de 1992, 1993 e 1995 apontaram que os principais fatores contributivos da desigualdade e pobreza piauiense são a idade e a escolaridade. No domicílio urbano, destacam-se a idade e a escolaridade e, no rural, idade, horas de trabalho e escolaridade. $\mathrm{Na}$ atividade agrícola, a idade, a posição na ocupação e horas de trabalho.

A pobreza nos anos 90 é ainda elevada, com uma proporção de pobres entre as pessoas economicamente ativas de 50,8\% (1995) no domicílio urbano. Essa proporção se eleva para $78,3 \%$ quando se considera o domicílio rural e para $80,1 \%$ quando são as pessoas ocupadas na agricultura. Pode-se, portanto, afirmar que a pobreza piauiense é, ainda, essencialmente rural.

Por isso, é relevante estudar as propostas existentes, oriundas dos governos federal/estadual/municipal e das organizações não governamentais, concernentes à geração de renda agrícola no Piauí, de modo a fundamentar novas políticas de renda e de combate à pobreza rural. Entretanto, o desenho de políticas sociais deve passar prioritariamente pelo incentivo à educação e alternativas de aumento da renda rural, contemplando formas de renda oriundas de atividades não-agrícolas.

Nos programas de redução da pobreza rural é preciso considerar que, nos anos 80 , ocorreram modificações no meio rural brasileiro que vêm se processando de forma mais lenta no Estado do Piauí. Não se pode mais pensar no rural como um espaço exclusivamente agropecuário, mas considerar também outras dimensões, como moradia, transformação industrial (agroindústria e de indústrias de pequeno porte), artesanato, lazer e preservação ambiental 
Para tanto, é necessário dotar, inicialmente, o espaço rural piauiense de infraestrutura básica (luz elétrica, água potável, saneamento básico, ensino, saúde, etc.), porque uma infra-estrutura adequada é essencial à redução da pobreza, seja como forma de melhoria das condições de vida através do acesso das pessoas a serviços básicos, seja como um meio de criar condições para aumento de renda, produtividade e nível de emprego. 


\section{REFERÊNCIAS BIBLIOGRÁFICAS}

ALBUQUERQUE, Roberto Cavalcanti de. Estratégia de desenvolvimento e combate à pobreza. Estudos Avançados, São Paulo, v.9, n. 24, , p.75-118, mai./ago.1995.

AZZONI, Carlos Alberto. Concentração regional e dispersão das rendas per capita estaduais: análise a partir de séries históricas estaduais de PIB, 1939-1995. Estudos Econômicos. São Paulo, v.27, n.3, p.341-393, set./dez 1997.

BANDEIRA, W. J. A estrutura agrária e o desenvolvimento econômico-social do Piauí. Estudos Diversos. Teresina, v.1, n.21, p.1-161, 1983 b.

O Piauí e a divisão regional do trabalho no Brasil. Carta CEPRO, Teresina, v.9, n.1, p.1-66, jul./dez.1983a.

A nova dinâmica do setor rural piauiense. Carta CEPRO. Teresina, v.15, n.1, p.46-55, jan./jun. 1994 .

Os programas e projetos governamentais e seus efeitos sobre a estrutura agrária piauiense no pós-70. Campinas, 1993. v.I e II. Tese (Doutorado em Economia) - Instituto de Economia, Universidade Estadual de Campinas.

BANDEIRA, Wiliam Jorge, SANTOS, Antônio de Pádua Silva Santos, LIMA, Gerson Portela. Diagnóstico das condições de sustentabilidade econômica-sociais formulação de linhas estratégicas para o desenvolvimento econômico do Piauí num horizonte de tempo de $\mathbf{2 5}$ anos. Teresina: SEPLAN/PI. mar. 1995. 
BARBOSA, Elias Alves. Índice de preços ao consumidor ( custo de vida ) - Teresina. Concepção e aspectos metodológicos. Carta CEPRO, Teresina, v.16, n.1, p.76-87, 1995.

BARROS, Ricardo P. de , MEDONÇA, Rosane S. P. de. A evolução do bem-estar e da desigualdade no Brasil desde 1960. In: SEMINÁRIO DESENVOLVIMENTO ECONÔMICO, INVESTIMENTO, MERCADO DE TRABALHO E DISTRIBUIÇÃO DA RENDA. Anais... Rio de Janeiro: PNUD/BNDES, 1992. p.1344.

BARROS, Ricardo Paes de, REIS, José Guilherme A., Educação e desigualdade de salários. Perspectivas da Economia Brasileira. Rio de Janeiro, p.335-362, 1989.

BELLUZZO, L. G. de M. Distribuição de renda; uma visão da controvérsia. In: TOLIPAN, R., TINELLI, A. C (Org.). A controvérsia sobre a distribuição de renda e desenvolvimento. 2. ed. Rio de Janeiro: Zahar, 1978. p.15-35.

BOLETIM DO DIEESE. São Paulo: DIEESE, v.13, n. 164, 1994.

BONFIM, W. L. de S., SANTOS JÚNIOR, R. B. do. Formação política; Piauí. In: SANTANA, R. N. Monteiro (Org.). Formação. Desenvolvimento. Perspectivas. Teresina: FUNDAPI, 1995. p.41-54

BRAGA, Helson C., MATESCO, Virene. O novo modelo de desenvolvimento industrial. Perspectivas da Economia Brasileira. Rio de Janeiro, p.451-475, 1989.

BRASIL 95: Crise social. Folha de São Paulo, São Paulo, 26 de jun.1994.

CACCIAMALI, Maria Cristina, FREITAS, Paulo Springer. Do capital humano ao salário - eficiência: uma aplicação para analisar os diferenciais de salários em cinco ramos manufatureiros da Grande São Paulo. Pesquisa e Planejamento Econômico. Rio de Janeiro, v. 22, n. 2, p.343-367, ago. 1992.

CACCIAMALI, Maria Cristina. Aspectos da distribuição da renda no Brasil. In: PINHO, D. B., VASCONCELLOS, M. A. S. (Org.). Manual de economia.. 2. ed. São Paulo: Saraiva, 1992. Cap. 3, p.405-422, Parte III.

CAMARgO, José Márcio, BARROS, Ricardo Paes. As causas da pobreza no Brasil: porca miséria!. Perspectivas da Economia Brasileira. Rio de Janeiro, p.525-544, 1991. 
CARDOSO, Eliana, BARROS, Ricardo, URANI, André. Inflation and Unemployment as determinants of inequality in Brazil: the 1980. Rio de Janeiro: IPEA, 1993a (Texto para discussão, 298)

CARDOSO, Eliana. Cyclical variations of earnings inequality in brazil. Revista de Economia Política, São Paulo, v.13, n. 4, p.112-124, out./dez. 1993 b.

CAVALCANTI, Clóvis. Piauí: bolsão de miséria no nordeste do Brasil. In: BAER, Werner, GEIGER, Pedro Pinchas HADDAD, Paulo Roberto (Coords.). Rio de Janeiro, Campus. 1978. p.283-299 (Contribuições em economia, 3).

CARVALHO, José A. M. de. Um Brasil mais velho e mais estável Brasil dos brasileiros. Revista Imprensa, v.7, n. 76, jan. 1994. Anexo especial.

CASTRO, A. B. de. Prefácio. In: CAMARGO, J. M., GIAMBIAGI, F. (Org.) Distribuição de renda no Brasil. Rio de Janeiro: Paz e Terra, 1991.

CORRÊA, A. M. C. J. Distribuição de rendimentos e pobreza na agricultura brasileira: 1981-1990. Piracicaba, 1995. Tese (Doutorado em Economia Agrária ) - Escola Superior de Agricultura Luiz de Queiroz, Universidade de São Paulo.

CORREAA, A. M. C. J., HOFFMANN, R. Distribuição da renda entre as pessoas ocupadas na agricultura brasileira; 1981-90. Curitiba: SOBER, 1995, p.14611478 .

Fatores condicionantes da desigualdade de rendimentos na agricultura paulista; 1981-90. In: CONGRESSO BRASILEIRO DE ECONOMIA E SOCIOLOGIA RURAL, 34, Aracajú, 1996., 1996. Anais... Aracajú: SOBER, 1996. p. $80-92$.

Desigualdade e concentração de renda no Brasil. Pesquisa DIEESE. São Paulo, n. 11, ago. 1995.

DOMINGOS NETO, M. Seca seculorum, flagelo e mito na economia rural piauiense. Teresina: Fundação CEPRO, 1983.

DROBNY, Andrés, WELLS, John. A distribuição da renda e o salário mínimo no Brasil: uma revisão crítica da literatura existente. Pesquisa e Planejamento Econômico. Rio de Janeiro.v.12, n. 2, p.893-914, dez. 1982. 
DUARTE, J. C. Aspectos da distribuição da renda no Brasil em 1970. Piracicaba, 1971. Dissertação (Mestrado em Economia Agrária). Escola Superior de Agricultura Luiz de Queiroz, Universidade de São Paulo, 1971.

FISHLOW, Albert, FISZBEIN, Ariel, RAMOS, Lauro. Distribuição de renda no Brasil e na Argentina: uma análise comparativa. Pesquisa e Planejamento Econômico. Rio de Janeiro, v.23, n. 1, p.1-32, abr. 1993.

FISHLOW, Albert. A distribuição de renda no Brasil. In: TOLIPAN, R., TINELLI, A. C (Org.). A controvérsia sobre a distribuição de renda e desenvolvimento. 2. ed. Rio de Janeiro: Zahar, 1978, p.159-189.

. Brazilian size distribution of income. The Americam Economic Review. New Orleans. p.391-402. may 1972.

. Distribuição de renda no Brasil - Um novo exame. Dados, Rio de Janeiro, n. 11, p.10-80, 1973.

Emergentes. Folha de São Paulo, São Paulo, 27 de nov. 1996, Caderno Especial.

SALOMON, Marta. Brasil tem 50 milhões de "clandestinos". Folha de São Paulo, , São Paulo, 17 de nov. 1996, Caderno Brasil, p.1-12.

FOSTER, James, GREER, Joel, THORBECKE, Erik. Notes e comments: a class of decomposable poverty measures. Econometrica. v. 52, n. 3, p. 761-766, may 1984.

GOMES, J. M. A. Produção e reprodução do "atraso " da agricultura piauiense: a pequena produção agrícola. Campina Grande, 1992. Dissertação (Mestrado em Economia Rural). Departamento de Economia, Universidade Federal da Paraíba.

HOFFMANN, Rodolfo. Tendências da distribuição da renda no Brasil e suas relações com o desenvolvimento econômico. In: TOLIPAN, R., TINELLI, A. C. (Org.). A Controvérsia sobre a distribuição de renda e desenvolvimento. 2.ed., Rio de Janeiro: Zahar, 1978. p.105-123.

Considerações sobre a evolução recente da distribuição da renda no Brasil. Revista de Administração de Empresas. Rio de Janeiro, v.13, n.4, p.7-17, out./dez. 1973. 
HOFFMANN, Rodolfo. A distribuição da renda no Brasil. Revista de Administração de Empresas. Rio de Janeiro, v.12, n. 2, p.46-66, abr./jun. 1972.

A pobreza no Brasil: análise dos dados dos Censos demográficos de $1970 \mathrm{e}$ 1980. In: ENCONTRO BRASILEIRO DE ECONOMETRIA, 6, São Paulo, 1984. Anais... São Paulo, SBE, 1984.

A subdeclaração dos rendimentos. São Paulo em Perspectiva. Rio de Janeiro, v. 2, n.1, p.50-54, jan./mar. 1988 .

Desigualdade e pobreza no Brasil no período 1979-90. Revista Brasileira de Economia. Rio de Janeiro, v.49, n.2, p.277-294, abr.jun.1995a.

Distribuição da renda e pobreza na agricultura brasileira. Agricultura e Políticas Públicas. Brasília, n.127, p.3-111, 1990.

. Distribuição da renda e pobreza na agricultura gaúcha. Indicadores Econômicos. Porto Alegre, v. 21, n.4, p.201-216, jan.1994.

Pobreza, insegurança alimentar e desnutrição no Brasil. Estudos Avançados. São Paulo, v.9, n.24, p.159-172, mai./ago.1995b.

Relações entre pobreza absoluta, renda média e desigualdade da distribuição de renda. Pesquisa e Planejamento Econômico. Rio de Janeiro, v.25, n. 2, p.337-358, ago.1995c.

Sensibilidade das medidas de desigualdade a transferências regressivas. Pesquisa e Planejamento Econômico. Rio de Janeiro, v. 22, n. 2, p.289-304, ago.1992a.

Sensibilidade das medidas de pobreza à redução da renda de um pobre. Salvador. In: ENCONTRO BRASILEIRO DE ECONOMETRIA, 17, 1995, Salvador, Anais... Salvador: 1995d, v. 2, p.623-632. 
HOFFMANN, Rodolfo. Vinte anos de desigualdade e pobreza na agricultura brasileira.

Revista de Economia e Sociologia Rural, Brasília, v.30, n.2, p.97-113, abr./jun. 1992b.

A dinâmica da modernização da agricultura e a distribuição da renda em 157 microrregiões homogêneas do Brasil. Piracicaba: ESALQ/USP, 1992c. (Relatório de pesquisa).

. Contribuição à análise da distribuição da posse da terra no Brasil.

Piracicaba, 1967. Tese (Título "Magister Scientiae" em Ciências Sociais). Escola Superior de Agricultura Luiz de Queiroz, Universidade de São Paulo.

Contribuição à análise da distribuição da renda e da posse da terra no Brasil. Piracicaba, 1971. Tese (Livre Docência), Escola Superior de Agricultura Luiz de Queiroz, Universidade de São Paulo.

Desigualdade e pobreza na agricultura de Goiás: 1970-1990. Revista de Economia e Sociologia Rural, Brasília, v.32, n.3, p.237-254, jul./set., 1994.

HOFFMANN, R.. Distribuição da renda e pobreza entre as famílias no Brasil, de 1980 e 1983. Revista de Economia Política, São Paulo, v.5, n.3, p.50- 60, 1985.

Distribuição da renda e pobreza na agricultura brasileira. São Paulo: IPEA, ESALQ/USP, 1987. (Relatório de pesquisa).

1982a.

Distribuição da renda no Brasil em 1980. Piracicaba: ESALQ/USP,

Distribuição da renda no Brasil, em 1980, por unidades da Federação. Piracicaba: ESALQ/USP, 1982b

Comentários sobre o trabalho de Francisco H.G. Ferreira e Julie A. Litchfield. Piracicaba. ESALQ/USP, 1996a digitado.

Desigualdade e pobreza no Brasil: atualização até 1995. Piracicaba. ESALQ/USP, set. 1996b digitado. 
HOFFMANN, Rodolfo. Ricos e pobres na agricultura brasileira em 1995. Piracicaba. ESALQ/USP, set., 1996b digitado.

Income distribution in Brazil and the regional and sectoral contrasts. Piracicaba, ESALQ/USP, $1997 \mathrm{~b}$ digitado.

Desigualdade e pobreza no Brasil no período 1979-96 e a influência da inflação e do salário mínimo. Piracicaba: ESALQ/USP, 1998 digitado.

HOFFMANN, R., DUARTE, J. C. A distribuição de renda no Brasil. Revista de Administração de Empresas, n. 12, 1972.

HOFFMANN, R., SILVA, J. Graziano da Desigualdade e estratificação social. Revista de Finanças Públicas, v.39, n.339, jul./set. 1979.

HOFFMANN, R., KAGEYAMA A. Modernização da agricultura e distribuição de renda no Brasil. Pesquisa e Planejamento Econômico, Rio de Janeiro, v. 15, n.1, p.171208, abr. 1985.

A distribuição da renda no Brasil entre famílias e entre pessoas, em 1970 e 1980. Estudos Econômicos, São Paulo, v.16, n.1, p.25-47, 1986.

INSTITUTO BRASILEIRO DE GEOGRAFIA E ESTATÍSTICA. Censo demográfico; 1983. Mão-de-obra, Brasil. Rio de Janeiro: IBGE, v.1, t.5, n.1,1983.

INSTITUTO BRASILEIRO DE GEOGRAFIA E ESTATISTICA. Tendências demográficas: uma análise a partir dos resultados do censo demográfico de 1991. Rio de Janeiro: IBGE, Departamento de População e Indicadores Sociais, 1996.

INSTITUTO BRASILEIRO DE GEOGRAFIA E ESTATÍSTICA. Censo demográfico 1991. Situação demográfica, social e econômica: primeiras considerações. Estado do Piauí. Rio de Janeiro: IBGE, Departamento de População e Indicadores Sociais, 1995.

INSTITUTO BRASILEIRO DE GEOGRAFIA E ESTATÍSTICA. Pesquisa nacional por amostra de domicílios-1984. Maranhão - Piauí - Ceará - Rio Grande do Norte - Paraíba - Pernambuco - Alagoas - Sergipe - Bahia. Rio de Janeiro: IBGE, v. 8, t. $4,1984$.

INSTITUTO BRASILEIRO DE GEOGRAFIA E ESTATÍSTICA. Pesquisa nacional por amostra de domicílios-1985. Maranhão-Piauí-Ceará-Rio Grande do NorteParaíba-Pernambuco-Alagoas-Sergipe-Bahia. Rio de Janeiro: IBGE, v.9, t.4, 1985. 
INSTITUTO BRASILEIRO DE GEOGRAFIA E ESTATÍSTICA. Pesquisa nacional por amostra de domicílios-1986. Maranhão-Piauí-Ceará-Rio Grande do NorteParaíba-Pernambuco-Alagoas-Sergipe-Bahia. Rio de Janeiro: IBGE, v.10, t.4, 1986.

INSTITUTO BRASILEIRO DE GEOGRAFIA E eStatístiCA. Pesquisa nacional por amostra de domicílios-1987. Maranhão-Piauí-Ceará-Rio Grande do NorteParaíba-Pernambuco-Alagoas-Sergipe-Bahia. Rio de Janeiro: IBGE, v.11, t.4, 1987.

INSTITUTO BRASILEIRO DE GEOGRAFIA E ESTATISTTICA. Pesquisa nacional por amostra de domicílios-1988. Maranhão-Piauí-Ceará-Rio Grande do NorteParaíba-Pernambuco-Alagoas-Sergipe-Bahia. Rio de Janeiro: IBGE, v.12, t.4, 1988.

INSTITUTO BRASILEIRO DE GEOGRAFIA E ESTATÍSTICA. Pesquisa nacional por amostra de domicílios-1989. Maranhão-Piauí-Ceará-Rio Grande do NorteParaíba-Pernambuco-Alagoas-Sergipe-Bahia. Rio de Janeiro: IBGE, v.13, t.4, 1989.

INSTITUTO BRASILEIRO DE GEOGRAFIA E ESTATÍSTICA. Pesquisa nacional por amostra de domicílios-1990. Maranhão-Piauí-Ceará-Rio Grande do NorteParaiba-Pernambuco-Alagoas-Sergipe-Bahia. Rio de Janeiro: IBGE, v.14, t.4,1990.

INSTITUTO BRASILEIRO DE GEOGRAFIA E ESTATÍSTICA. Pesquisa nacional por amostra de domicílios-1992. Piauí. Rio de Janeiro: IBGE, v.15, n. 15, 1992.

INSTITUto bRasileiro DE GEOGRAFIA e eStatístiCA. Pesquisa nacional por amostra de domicílios-1993. Piauí. Rio de Janeiro: IBGE, v. 16, n.15, 1993.

INSTITUTO BRASILEIRO DE GEOGRAFIA E ESTATÍSTICA. Pesquisa nacional por amostra de domicílios-1995. Piauí. Rio de Janeiro: IBGE, 1995.

INSTITUTO BRASILEIRO DE GEOGRAFIA E ESTATÍSTICA. Pesquisa nacional por amostra de domicílios-1996. Piauí. Rio de Janeiro: IBGE, 1996.

INSTITUTO DE PESQUISA ECONÔMICA APLICADA. Relatório sobre o desenvolvimento humano no Brasil. Rio de Janeiro, Brasília, DF: PNUD, 1996.

KANBUR, Ravi. Pobreza e desenvolvimento: Human development report e World development report, 1990. Revista Brasileira de Economia, Rio de Janeiro, v.45, n. 3, p.397-415, jul./set.1991. 
KAGEYAMA, A., REHDER, P. O bem-estar rural no Brasil na década de oitenta. Revista de Economia e Sociologia Rural. Brasília, v.31, n.1, p.23-44, jan./mar.1993.

LAMPREIA, Luiz Felipe. Relatório brasileiro sobre desenvolvimento social. Estudos Avançados, São Paulo, v.9, n. 24, p.9-74, mai./ago.1995.

LANGONI, C. G. Distribuição de renda e desenvolvimento econômico no Brasil. Rio de Janeiro: Expressão e Cultura, 1973a.

. Distribuição da Renda: Resumo da Evidência. Dados, Rio de Janeiro, n. 11, p.81-121, 1973b.

LAVINAS, Lena, GARCIA, Eduardo H., AMARAL, Marcelo R. do. Desigualdades regionais: indicadores sócio-econômicos nos anos 90 . Revista Econômica do Nordeste, Fortaleza, v.27, n. 4, p.857-921, out./dez. 1996.

LEONE, Eugênia Troncoso. Manifestações da pobreza agrícola no Brasil em 1990. Campinas: IE/UNICAMP, 1995. (Texto para Discussão 46)

LOPES, José Sérgio Leite. Sobre o debate da distribuição da renda: leitura crítica de um artigo de Fishlow. In: TOLIPAN, R., TINELLI, A. C (Org.). A controvérsia sobre a distribuição de renda e desenvolvimento. 2. ed. Rio de Janeiro: Zahar, 1978. p.289-317.

LUSTIG, Nora, MCLEOD, Darryl. Minimum wages and poverty in developing countries: some empirical evidence. Bookings Discussion Papers in Internacional Economics, n.125, june 1996.

MARTINS, A. de S., ROCHA, J., MEDEIROS, A. J. et al. Piauí; evolução, realidade e desenvolvimento. Teresina: Fundação CEPRO, 1979.

MARTINE, George. Os mitos demográficos e os censos. Brasil dos brasileiros. Revista Imprensa, v. 7, n. 76, p. 12-15, jan. 1994. Anexo especial

MATOS, M. de F. A. Localização e caracterização da pobreza urbana na grande Teresina. Carta CEPRO, Teresina, v.16, n.1, p.9-30, jan./jun. 1995.

MILLER, Lilian Maria. A distribuição da renda pessoal. In: Indicadores sociais: uma análise da década de 1980. Rio de Janeiro: IBGE/Diretoria de Pesquisas, 1995. p.181-194. 
MONTEIRO NETO, Aristides. Desigualdades setoriais e crescimento do PIB no Nordeste: uma análise do período 1970/1995. Brasília: IPEA. mai.1997. (Texto para Discussão, 484)

OLIVEIRA, Jane Souto, PORCARO, Rosa Maria, JORGE, Angela Filgueiras. In: Indicadores sociais: uma análise da década de 1980. Rio de Janeiro: IBGE/ Diretoria de Pesquisas, 1995. p. 145-179

PATARRO, Neide. Eis a nova cara do Brasil. Brasil dos brasileiros. Revista Imprensa. v.7, n. 76, jan.1994. Anexo especial.

PINTO, L.C. G. Contribuição ao estudo da distribuição da renda no Brasil; análise do imposto sobre a renda pessoa física e dos salários nas indústrias de transformação. Piracicaba, 1972. Tese (Doutorado em Economia Agrária) - Escola Superior de Agricultura Luiz de Queiroz, Universidade de São Paulo.

POCHMANN, Márcio. Trinta anos de políticas salariais no Brasil. In OLIVEIRA, Carlos Alonso Barbosa de et al (Org.). O mundo do trabalho: crise e mudança do final do século. São Paulo, CESIT/IE/UNICAMP, Página Aberta, p.641-671, 1994.

Desigualdade dos rendimentos: o que há de novo? Campinas.

CESIT/IE/UNICAMP, ago. 1997. versão preliminar

. Fermenta a desigualdade. Carta Capital, São Paulo, v.3, n.58, p.36-39, out.1997. Entrevista a Carlos Drummond

RAMOS, Lauro. Poverty in the 80s. Rio de Janeiro: IPEA. 1994. (Texto para Discussão, 361)

REIS, José Guilherme A., RAMOS, Lauro. Quem ganha salário mínimo no Brasil?. Rio de Janeiro: IPEA. 1993. (Texto para Discussão, 320)

REIS, José Guilherme A., RAMOS, Lauro. Minimum wage, income distribution, and poverty in Brazil. Rio de Janeiro: IPEA. 1994. (Texto para Discussão, 359)

Salário mínimo e distribuição da renda. In: Perspectivas da Economia Brasileira, Rio de Janeiro: IPEA/INPES. 1989. p.371-391.

ROCHA, Sônia. Governabilidade e pobreza . O desafio dos números. Rio de Janeiro: IPEA. 1995. (Texto para Discussão, 368) 
Poverty studies in Brazil - a review. Rio de Janeiro: IPEA. 1996.

(Texto para Discussão, 398)

ROCHA, Sônia, TOLOSA, Hamilton. Pobreza metropolitana e políticas sociais. In:

Perspectivas da Economia Brasileira, Rio de Janeiro: IPEA/INPES. 1989. p.403-429.

RODRIGUES, M. C. P. O IDS e o desenvolvimento social nas grandes regiões e nos estados brasileiros. Rio de Janeiro: FGV, 1994a.

O desenvolvimento social dos estados brasileiros. Conjuntura Econômica Rio de Janeiro: v.48, n.3, p.52-56, mar. 1994b.

Os pobres e os ricos do Brasil. Conjuntura Econômica, Rio de Janeiro, v.47, n.3, p.46-49, mar. $1993 \mathrm{a}$.

Os pobres e os ricos do Brasil. Conjuntura Econômica, Rio de Janeiro, v. 47, n. 11, p. $54-57$, nov. 1993 b.

ROMÃO, M. E. C. Pobreza: conceito e mensuração. Rio de Janeiro: IPEA, 1993.

ROMÃO, M. E. C. Índices de pobreza: alternativas, decomposição e uso com dados agregados. Estudos Econômicos, São Paulo, v.12, n.3, p.51-65, dez. 1982.

RYFF, Tito. Introdução ao tema distribuição da renda. Dados, Rio de Janeiro, n.11, p.59. 1973.

SANDSTRÖM, S. Redução da pobreza; aprendendo com a experiência. Finanças \& Desenvolvimento, Rio de Janeiro, v.14, n.3, p.30-33, set. 1994.

SANTANA, R. N. Evolução histórica de economia piauiense. Teresina: Cultura, 1964.

SANTOS, A. de P. S. Agregados macroeconômicos. In: Política de desenvolvimento sustentável para o Nordeste semi-árido. Teresina: 1995.

SEDLACEK, Guilherme Luis. A evolução da distribuição de renda entre 1984 e 1987. In: Perspectivas da Economia Brasileira, Rio de Janeiro: IPEA/INPES. 1989. p.363-369 
SENNA, José Júlio. Escolaridade, experiência no trabalho e salários no Brasil. Revista Brasileira de Economia, Rio de Janeiro, v.30, n. 2, p.163-193, abr.jjun. 1976.

SERRA, José. A reconcentração da renda: justificações, explicações, dúvidas. In: TOLIPAN, R., TINELLI, A. C (Org.). In: A controvérsia sobre a distribuição de renda e desenvolvimento. 2. ed. Rio de Janeiro: Zahar, 1978. p.263-288.

SILVA, J. F. Graziano da. A industrialização e urbanização da agricultura brasileira. São Paulo em Perspectiva, São Paulo: SEADE . 1995. p.197-221

Interpretação crítica de alguns recentes estudos sobre distribuição da renda no Brasil. Piracicaba, 1974. Dissertação (Mestrado em Economia Agrária) - Escola Superior de Agricultura Luiz de Queiroz, Universidade de São Paulo.

Evolução do emprego rural na década de oitenta. In OLIVEIRA, Carlos Alonso Barbosa de et al (Org.). In: $\mathbf{O}$ mundo do trabalho: crise e mudança do final do século. São Paulo, Página Aberta. 1994. p.619-640.

., DEL GROSSI, Mauro E. A mudança no conceito de trabalho nas novas PNADs. Economia e Sociedade, Campinas, v.8, p.247-261, jun. 1997.

SILVA, Luiz Carlos Eichenberg ( Coord.). O que mostram os indicadores sobre a pobreza na década perdida. Rio de Janeiro: IPEA. 1992. (Texto para Discussão, 274)

SINGER, Paul. Desenvolvimento e repartição da renda no Brasil. In: TOLIPAN, R., TINELLI, A. C (Org.).In: A controvérsia sobre a distribuição de renda $\mathbf{e}$ desenvolvimento. 2. ed. Rio de Janeiro: Zahar. 1978. p.73-104.

SMITH, Roberto. Aspectos da industrialização no Nordeste e a dinâmica da acumulação. In: ENCONTRO NACIONAL DE ECONOMIA, 12,1984. Anais... v.2, p. 1032-1052. 1984.

SOUSA, Lysia Bucar Lopes de. Formação do mercado de trabalho no Piaui:1960-1970. Particularidades histórico-econômicas do caso nordestino. São Paulo, 1996. Tese (Doutorado em História Econômica) - Faculdade de Filosofia, Letras e Ciências Humanas, Universidade de São Paulo.

WELLS, John, MALAN, Pedro. Distribuição de renda desenvolvimento econômico do Brasil. In TOLIPAN, R., TINELLI, A. C (Org.). A controvérsia sobre a distribuição de renda e desenvolvimento. 2. ed. Rio de Janeiro: Zahar.1978. p.241-262 
APÊNDICES 


\section{APENDICE 1}

Tabela A.1. Participação da Região Nordeste e Estados no PIB brasileiro em 1960, 1970,1980 e de 1985 a 1995.

\begin{tabular}{|c|c|c|c|c|c|c|c|}
\hline & \multicolumn{7}{|c|}{ PERIODOS } \\
\hline & 1960 & 1970 & 1980 & 1985 & 1986 & 1987 & 1988 \\
\hline NORDESTE & 14,5 & 11,9 & 12,2 & 13,8 & 14,2 & 14,1 & 14,2 \\
\hline Maranhão & 1,1 & 0,9 & 0,9 & 1,0 & 1,1 & 1,1 & 1,2 \\
\hline PIAUI & 0,4 & 0,4 & 0,4 & 0,4 & 0,5 & 0,5 & 0,5 \\
\hline Ceará & 1,9 & 1,5 & 1,5 & 1,7 & 1,7 & 1,7 & 1,7 \\
\hline Rio Grande do Norte & 0,9 & 0,6 & 0,6 & 0,9 & 0,9 & 1,0 & 1,1 \\
\hline Paraiba & 1,4 & 0.7 & 0,7 & 0,7 & 0,7 & 0,8 & 0,7 \\
\hline Pernambuco & 3,5 & 3,0 & 2,6 & 2,4 & 2,5 & 2,6 & 2,6 \\
\hline Alagoas & 0,8 & 0,7 & 0,7 & 0,7 & 0,7 & 0,7 & 0,7 \\
\hline Sergipe & 0,5 & 0,4 & 0,4 & 0,7 & 0,8 & 0,8 & 0,7 \\
\hline \multirow[t]{3}{*}{ Bahia } & 4,2 & 3,8 & 4,4 & 5,2 & 5,3 & 5,0 & 5,1 \\
\hline & \multicolumn{7}{|c|}{ PERIODOS } \\
\hline & 1989 & 1990 & 1991 & 1992 & 1993 & 1994 & 1995 \\
\hline NORDESTE & 14,3 & 14,1 & 14,2 & 14,0 & 13,9 & 13,9 & 13,7 \\
\hline Maranhão & 1,1 & 1,2 & 1,1 & 1,0 & 1,1 & 1,1 & 1,1 \\
\hline PIAUI & 0,5 & 0,5 & 0,5 & 0,4 & 0,5 & 0,5 & 0,5 \\
\hline Ceará & 1,6 & 1,7 & 1,9 & 1,9 & 1,9 & 1,9 & 1,9 \\
\hline Rio Grande do Norte & 1,1 & 0,9 & 1,0 & 0,9 & 0,9 & 0,9 & 0,9 \\
\hline Paraiba & 0,7 & 0,8 & 0,8 & 0,8 & 0,7 & 0,8 & 0,8 \\
\hline Pemambuco & 2,7 & 2,6 & 2,8 & 2,6 & 2,5 & 2,5 & 2,5 \\
\hline Alagoas & 0,7 & 0,9 & 0,8 & 0,8 & 0,8 & 0,8 & 0,8 \\
\hline Sergipe & 0,8 & 0,8 & 0,8 & 0,8 & 0,8 & 0,7 & 0,7 \\
\hline Bahia & 5,0 & 4,8 & 4,7 & 4,8 & 4,8 & 4,8 & 4,6 \\
\hline
\end{tabular}

Fonte: Dados extraídos de Azzoni (1997, p.377-379). 


\section{APÊNDICE 2}

Tabela A.2. Valores PIB per capita (US\$ constantes de 1995) para o Brasil, Região Nordeste e Estados do Nordeste em 1960, 1970, 1980 e de 1985 a 1995.

\begin{tabular}{|c|c|c|c|c|c|c|c|}
\hline & \multicolumn{7}{|c|}{ PERIODOS } \\
\hline & 1960 & 1970 & 1980 & 1985 & 1986 & 1987 & 1988 \\
\hline NORDESTE & 660,02 & 777,06 & 1447,35 & 1613,65 & 1750,11 & 1774,68 & 1747,01 \\
\hline Maranhão & 445,65 & 526,30 & 900,21 & 1053,87 & 1213,08 & 1191,54 & 1234,96 \\
\hline PIAUÍ & 320,65 & 414,93 & 740,38 & 826,68 & 946,55 & 944,82 & 950,40 \\
\hline Ceará & 579,92 & 619,66 & 1198,60 & 1296,18 & 1398,68 & 1384,45 & 1362,69 \\
\hline Rio Grande do Norte & 765,24 & 652,70 & 1405,31 & 1865,51 & 2055,16 & 2331,79 & 2327,71 \\
\hline Paraíba & 683,71 & 566,92 & 1005,01 & 1062,24 & 1166,90 & 1242,95 & 1130,67 \\
\hline Pernambuco & 858,19 & 1048,38 & 1722,51 & 1640,48 & 1768,22 & 1875,05 & 1858,90 \\
\hline Alagoas & 628,24 & 808,32 & 1406,96 & 1460,70 & 1422,48 & 1594,00 & 1455,68 \\
\hline Sergipe & 642,91 & 902,73 & 1444,43 & 2366,08 & 2866,80 & 2973,54 & 2652,84 \\
\hline Bahia & 708,70 & 933,98 & 1949,35 & 2227,51 & 2368,72 & 2278,35 & 2278,25 \\
\hline \multirow[t]{3}{*}{ BRASIL } & 1445,92 & 1966,88 & 3476,12 & 3395,94 & 3586,89 & 3648,75 & 3582,70 \\
\hline & \multicolumn{7}{|c|}{ PERIOODOS } \\
\hline & 1989 & 1990 & 1991 & 1992 & 1993 & 1994 & 1995 \\
\hline NORDESTE & 1793,96 & 1657,11 & 1655,22 & 1586,30 & 1614,12 & 1680,06 & 1692,57 \\
\hline Maranhão & 1231,16 & 1168,14 & 1092,45 & 1016,56 & 1091,68 & 1156,05 & 1152,87 \\
\hline PIAUI & 924,72 & 968,12 & 861,24 & 766,65 & 863,71 & 939,75 & 964,92 \\
\hline Ceará & 1367,80 & 1312,08 & 1436,38 & 1425,81 & 1439,87 & 1499,63 & 1539,44 \\
\hline Rio Grande do Norte & 2397,65 & 1872,91 & 2066,79 & 1790,07 & 1767,02 & 1957,55 & 1999,59 \\
\hline Paraiba & 1185,62 & 1245,23 & 1250,20 & 1164,85 & 1152,76 & 1237,26 & 1274,45 \\
\hline Pernambuco & 2028,07 & 1804,85 & 1914,29 & 1787,65 & 1777,60 & 1806,26 & 1890,44 \\
\hline Alagoas & 1578,26 & 1719,29 & 1553,00 & 1509,43 & 1521,84 & 1637,79 & 1610,97 \\
\hline Sergipe & 2782,49 & 2735,67 & 2516,62 & 2470,99 & 2450,54 & 2430,89 & 2441,42 \\
\hline Bahia & 2273,96 & 2027,82 & 1962,68 & 1941,98 & 1993,34 & 2050,66 & 2004,47 \\
\hline BRASIL & 3630,92 & 3411,63 & 3362,49 & 3275,48 & 3351,93 & 3480,89 & 3562,59 \\
\hline
\end{tabular}

Fonte: Dados extraidos de Azzoni (1997, p.385-387). 


\section{APENDICE 3}

Tabela A.3.1. Freqüência e freqüência relativa da amostra de $0,8 \%$ do Censo de 1980 para as pessoas economicamente ativas com rendimento, conforme setor; Piauí - 1980 .

\begin{tabular}{l|c|c|c|c}
\hline Setor & freqüência & $\%$ & frequêencia acumulada & $\%$ acumulado \\
\hline Agropecuário & 259.721 & 51,7 & 259721 & 51,7 \\
Urbanos & 69.587 & 13,8 & 329308 & 65,5 \\
Ativ.não def., mal def. e não aplicável & 173.311 & 34,5 & 502619 & 100,0 \\
\hline
\end{tabular}

Fonte: IBGE. Microdados da Amostra de 0,8\% do Censo Demográfico de 1980.

Nota: Ausência de 4.646 pessoas

Tabela A.3.2. Freqüência e freqüência relativa da amostra de $0,8 \%$ do Censo de 1980 para as pessoas economicamente ativas com rendimento, conforme sexo; Piauí - 1980 .

\begin{tabular}{l|c|c|c|c}
\hline Sexo & freqüência & $\%$ & freqüência acumulada & $\%$ acumulado \\
\hline Homem & 380.737 & 75,1 & 380.737 & 75,1 \\
Mulher & 126.527 & 24,9 & 507.265 & 100,0 \\
TOTAL & 507.265 & 100,0 & & \\
\hline
\end{tabular}

Fonte: IBGE. Microdados da Amostra de $0,8 \%$ do Censo Demográfico de 1980

Tabela A.3.3. Freqüência e freqüência relativa da amostra de $0,8 \%$ do Censo de 1980 para as pessoas economicamente ativas com rendimento, conforme idade; Piauí -1980

\begin{tabular}{l|c|c|c|c}
\hline Idade & freqüência & $\%$ & freqüência acumulada & $\%$ acumulado \\
\hline 10 a 14 anos & 13.392 & 2,6 & 13.392 & 2,6 \\
15 a 17 anos & 28.329 & 5,6 & 41.720 & 8,2 \\
18 a 19 anos & 25.516 & 5,0 & 67.236 & 13,3 \\
20 a 24 anos & 80.772 & 15,9 & 148.009 & 29,2 \\
25 a 29 anos & 72.197 & 14,2 & 220.206 & 43,4 \\
30 a 39 anos & 116.611 & 23,0 & 336.817 & 66,4 \\
40 a 49 anos & 83.713 & 16,5 & 420.530 & 82,9 \\
50 a 59 anos & 54.616 & 10,8 & 475.145 & 93,7 \\
60 anos ou mais & 32.119 & 6,3 & 507.265 & 100,0 \\
\hline
\end{tabular}

Fonte: IBGE. Microdados da Amostra de 0,8\% do Censo Demográfico de 1980 


\section{APÊNDICE 4}

Tabela A.4.1. Freqüência e freqüência relativa da amostra de $0,8 \%$ do Censo de 1980 para as pessoas economicamente ativas com rendimento, conforme posição na ocupação; Piauí - 1980.

\begin{tabular}{l|r|r|r|c}
\hline Posição na ocupação & freqüência & $\%$ & $\begin{array}{l}\text { freqüência } \\
\text { acumulada }\end{array}$ & \% acumulado \\
\hline sem remuneração & 734 & 0,1 & 734 & 0,1 \\
trabalhador volante com intermediário & 1.599 & 0,3 & 2.334 & 0,5 \\
trabalhador. Volante sem intermediário. & 19.681 & 3,9 & 22.015 & 4,3 \\
parceiro empregado & 3.725 & 0,7 & 25.740 & 5,1 \\
parceiro empregador & 1.283 & 0,3 & 27.023 & 5,3 \\
parceiro conta própria & 53.155 & 10,5 & 80.177 & 15,8 \\
empregado & 177.156 & 35,0 & 257.334 & 50,8 \\
empregador & 8.290 & 1,6 & 265.624 & 52,4 \\
conta própria & 239.571 & 47,3 & 505.195 & 99,7 \\
s/declaração/ não aplicável & 1.595 & 0,3 & 506.791 & 100,0 \\
\hline
\end{tabular}

Fonte: IBGE Microdados da Amostra de 0,8\% do Censo Demográfico de 1980.

Tabela A.4.2. Freqüência, freqüência relativa da amostra $0,8 \%$ do censo de 1980 para as pessoas economicamente ativas com rendimento, conforme escolaridade; Piauí -1980.

\begin{tabular}{l|c|r|l|c}
\hline Escolaridade & freqüência & $\%$ & $\begin{array}{l}\text { freqüência } \\
\text { acumulada }\end{array}$ & $\%$ acumulado \\
\hline sem instrução e menos de 1 ano & 273.085 & 53,8 & 273.085 & 53,8 \\
1 ano & 23,021 & 4,5 & 296.106 & 58,4 \\
2 anos & 34.808 & 6,9 & 330.914 & 65,2 \\
3 anos & 35.466 & 7,0 & 366.380 & 71,2 \\
4 anos & 52.022 & 10,3 & 418.402 & 82,5 \\
5 a 8 anos & 38.267 & 7,5 & 456.670 & 90,0 \\
9 a 11 anos & 41.018 & 8,1 & 497.689 & 98,1 \\
12 anos e mais & 8.587 & 1,7 & 506.275 & 99,8 \\
não det./s/ decl. e não aplicável & 989 & 0,2 & 507.265 & 100,0 \\
\hline
\end{tabular}

Fonte: IBGE. Microdados da Amostra de 0,8\% do Censo Demográfico de 1980. 


\section{APENDICE 5}

Tabela A.5. Medidas de tendência central e desigualdade para as pessoas economicamente ativas com rendimento; Brasil e Nordeste - 1984 a 1990, 1992, 1993, 1995 e 1996

\begin{tabular}{lr|c|c|c|c|c|c|c}
\hline & ANOS & $\begin{array}{c}\text { renda } \\
\text { média (1) }\end{array}$ & $\begin{array}{c}\text { Mediana } \\
(1)\end{array}$ & $\begin{array}{c}\text { Indice de } \\
\text { Gini }\end{array}$ & $\begin{array}{c}\text { Índice } \\
\text { de Theil }\end{array}$ & $50-$ & $10+$ & $5+$ \\
\hline 1984 & Nordeste & 1,32 & 0,70 & 0,581 & 0,515 & 14,4 & 48,0 & 35,4 \\
1985 & Brasil & 2,19 & 1,06 & 0,586 & 0,501 & 13,2 & 46,9 & 33,4 \\
& Nordeste & 1,49 & 0,75 & 0,603 & 0,556 & 13,3 & 50,1 & 37,4 \\
& Brasil & 2,54 & 1,20 & 0,599 & 0,525 & 12,6 & 48,0 & 34,5 \\
1986 & Nordeste & 2,08 & 1,00 & 0,581 & 0,525 & 14,5 & 48,4 & 35,8 \\
& Brasil & 3,55 & 1,72 & 0,589 & 0,528 & 13,3 & 47,8 & 34,6 \\
1987 & Nordeste & 1,62 & 0,76 & 0,612 & 0,560 & 12,7 & 50,8 & 37,8 \\
1988 & Brasil & 2,73 & 1,34 & 0,595 & 0,523 & 12,7 & 47,8 & 34,1 \\
& Nordeste & 1,55 & 0,72 & 0,635 & 0,599 & 11,6 & 53,5 & 40,5 \\
1989 & Brasil & 2,69 & 1,20 & 0,617 & 0,553 & 11,8 & 50,2 & 36,2 \\
1990 & Nordeste & 1,81 & 0,76 & 0,650 & 0,634 & 11,2 & 55,7 & 42,9 \\
& Brasil & 3,19 & 1,34 & 0,636 & 0,592 & 10,9 & 52,5 & 38,5 \\
1992 & Nordeste & 1,49 & 0,64 & 0,623 & 0,591 & 12,3 & 52,5 & 39,3 \\
& Brasil & 2,60 & 1,21 & 0,607 & 0,546 & 11,9 & 48,7 & 34,9 \\
1993 & Nordeste & 1,36 & 0,75 & 0,589 & 0,522 & 13,7 & 48,1 & 35,3 \\
& Brasil & 2,29 & 1,17 & 0,574 & 0,499 & 14,0 & 45,8 & 32,7 \\
1995 & Nordeste & 1,48 & 0,69 & 0,636 & 0,608 & 11,9 & 53,7 & 41,2 \\
& Brasil & 2,47 & 1,18 & 0,604 & 0,553 & 12,7 & 49,5 & 36,5 \\
1996 & Nordeste & 1,83 & 0,86 & 0,590 & 0,554 & 14,2 & 50,4 & 37,7 \\
& Brasil & 3,16 & 1,51 & 0,589 & 0,527 & 13,1 & 47,6 & 34,0 \\
& Nordeste & 1,94 & 0,88 & 0,598 & 0,563 & 13,7 & 50,9 & 38,2 \\
& Brasil & 3,26 & 1,61 & 0,585 & 0,516 & 13,4 & 47,3 & 33,6 \\
\hline
\end{tabular}

Fonte: IBGE. Dados básicos das PNAD de 1984 a 1996.

(1) em SM de ago./80 


\section{APENDICE 6}

Tabela A.6. Medidas de pobreza para as pessoas economicamente ativas com rendimento; Brasil e Nordeste - 1984 a 1990, 1992, 1993, 1995 e 1996.

\begin{tabular}{|c|c|c|c|c|c|c|}
\hline & & $\begin{array}{l}\text { Proporção de } \\
\text { pobres }(\mathrm{H})\end{array}$ & $\begin{array}{c}\text { Razão de } \\
\text { insuficiência }\end{array}$ & $\begin{array}{l}\text { Indice de } \\
\text { Sen }\end{array}$ & $r(\%)(1)$ & $\begin{array}{l}\text { Indice de } \\
\text { FGT }\end{array}$ \\
\hline 1984 & Nordeste & 0,671 & 0,504 & 0,439 & 25,6 & 0,216 \\
\hline & Brasil & 0,477 & 0,443 & 0,282 & 9,65 & 0,125 \\
\hline 1985 & Nordeste & 0,634 & 0,505 & 0,418 & 21,5 & 0,207 \\
\hline & Brasil & 0,427 & 0,436 & 0,251 & 7,32 & 0,111 \\
\hline 1986 & Nordeste & 0,500 & 0,396 & 0,273 & 9,5 & 0,113 \\
\hline & Brasil & 0,301 & 0,337 & 0,142 & 2,86 & 0,052 \\
\hline 1987 & Nordeste & 0,618 & 0,500 & 0,404 & 19,2 & 0,198 \\
\hline & Brasil & 0,393 & 0,430 & 0,227 & 6,20 & 0,099 \\
\hline 1988 & Nordeste & 0,648 & 0,527 & 0,444 & 22,0 & 0,223 \\
\hline & Brasil & 0,425 & 0,447 & 0,257 & 7,06 & 0,117 \\
\hline 1989 & Nordeste & 0,620 & 0,503 & 0,409 & 17,3 & 0,203 \\
\hline & Brasil & 0,399 & 0,418 & 0,227 & 5,22 & 0,100 \\
\hline 1990 & Nordeste & 0,668 & 0,523 & 0,443 & 23,4 & 0,223 \\
\hline & Brasil & 0,436 & 0,450 & 0,256 & 7,54 & 0,114 \\
\hline 1992 & Nordeste & 0,647 & 0,517 & 0,439 & 24,6 & 0,224 \\
\hline & Brasil & 0,435 & 0,426 & 0,252 & 8,10 & 0,111 \\
\hline 1993 & Nordeste & 0,667 & 0,532 & 0,460 & 24,0 & 0,239 \\
\hline & Brasil & 0,438 & 0,435 & 0,255 & 7,71 & 0,113 \\
\hline 1995 & Nordeste & 0,549 & 0,444 & 0,312 & 13,3 & 0,136 \\
\hline & Brasil & 0,315 & 0,401 & 0,163 & 3,99 & 0,065 \\
\hline 1996 & Nordeste & 0,548 & 0,433 & 0,307 & 12,2 & 0,131 \\
\hline & Brasil & 0,307 & 0,385 & 0,154 & 3,63 & 0,059 \\
\hline
\end{tabular}

Fonte: IBGE, dados básicos das PNADS de 1984 a 1996.

Nota: Considera linha de pobreza 1 SM ago.80, conforme INPC.

(1) Insuficiência da renda como porcentagem da renda total. 


\section{APENDICE 7}

Tabela A.7.1. Proporção de domicílios particulares permanente, segundo algumas características do domicílio urbano; Piauí-1984 a 1996.

\begin{tabular}{|c|c|c|c|c|c|c|c|c|c|c|c|}
\hline Características & 1984 & 1985 & 1986 & 1987 & 1988 & 1989 & 1990 & 1992 & 1993 & 1995 & 1996 \\
\hline \multicolumn{12}{|l|}{ abastecimento d'água } \\
\hline \multirow{2}{*}{$\begin{array}{l}\text { rede geral } \\
\text { outra forma }\end{array}$} & 75,6 & 76,9 & 78,0 & 80,8 & 84,8 & 85,0 & 85,7 & 82,1 & 85,6 & 88,2 & 90,2 \\
\hline & 24,4 & 23,1 & 22,0 & 19,2 & 15,2 & 45,0 & 14,3 & 17,9 & 14,4 & 11,8 & 9,8 \\
\hline \multicolumn{12}{|l|}{ esgotamento sanitário } \\
\hline \multirow{2}{*}{$\begin{array}{l}\text { tinham } \\
\text { nâo tinham }\end{array}$} & 67,6 & $\ldots$ & $\ldots$ & $\ldots$ & $\cdots$ & $\ldots$ & ... & 65,1 & 64,1 & 68,9 & 73,9 \\
\hline & 32,4 & $\ldots$ & $\ldots$ & $\ldots$ & $\ldots$ & $\ldots$ & $\ldots$ & 34,9 & 35,9 & 31,1 & 26,1 \\
\hline \multicolumn{12}{|l|}{ destino do lixo } \\
\hline \multirow{2}{*}{$\begin{array}{l}\text { coletado } \\
\text { outra forma }\end{array}$} & 30,8 & 33,4 & 37,4 & 33,8 & 36,1 & 38,5 & 39,2 & 47,3 & 49,0 & 47,5 & 47,4 \\
\hline & 69,2 & 66,6 & 62,6 & 66,2 & 63,9 & 61,5 & 60,8 & 52,7 & 51,0 & 52,5 & 52,6 \\
\hline \multicolumn{12}{|l|}{ iluminação elétrica } \\
\hline \multirow{2}{*}{$\begin{array}{l}\text { tinham } \\
\text { não tinham }\end{array}$} & 73,0 & 76,1 & 80,0 & 82,6 & 84,1 & 83,3 & 85,7 & 87,4 & 88,6 & 92,5 & 94,2 \\
\hline & 27,0 & 23,9 & 20,0 & 17,4 & 15,9 & 16,7 & 14,3 & 12,6 & 11,4 & 7,5 & 5,8 \\
\hline \multicolumn{12}{|l|}{ telefone } \\
\hline \multirow{2}{*}{$\begin{array}{l}\text { tinham } \\
\text { não tinham }\end{array}$} & $\cdots$ & $\cdots$ & ... & ... & & $\ldots$ & $\cdots$ & 16,5 & 15,9 & 21,9 & 22,4 \\
\hline & & & & & & & & 83,5 & 84,1 & 78,1 & 77,6 \\
\hline
\end{tabular}

Fonte: IBGE, dados básicos das PNAD de 1984 a 1990, 1992, 2993, 1995 e 1996.

Nota: ... dado numérico não disponivel.

Tabela A.7.2. Proporção de domicílios particulares permanente, segundo algumas características do domicílio rural,. Piauí-1984 a 1996.

\begin{tabular}{|c|c|c|c|c|c|c|c|c|c|c|c|}
\hline Caracteristicas & 1984 & 1985 & 1986 & 1987 & 1988 & 1989 & 1990 & 1992 & 1993 & 1995 & 1996 \\
\hline \multicolumn{12}{|l|}{ abastecimento dágua } \\
\hline rede geral & & & 1,9 & 1,2 & 0,3 & 2,0 & 3,3 & 7,0 & 7,0 & 10,5 & 15,3 \\
\hline outra forma & 100,0 & 100,0 & 98,1 & 98,8 & 99,7 & 98,0 & 96,7 & 93,0 & 93,0 & 89,5 & 84,7 \\
\hline esgotamento sanitário & & & & & & & & & & & \\
\hline tinham & 5,6 & $\ldots$ & $\ldots$ & $\ldots$ & $\ldots$ & $\ldots$ & $\ldots$ & 12,1 & 11,8 & 19,5 & 20,0 \\
\hline não tinham & 94,4 & $\ldots$ & $\ldots$ & $\ldots$ & $\ldots$ & $\ldots$ & $\ldots$ & 87,9 & 88,2 & 80,5 & 80,0 \\
\hline destino do lixo & & & & & & & & & & & \\
\hline coletado & & & & & & 0,5 & 0,5 & & & 0,2 & \\
\hline $\begin{array}{l}\text { outra forma } \\
\text { Iluminação elétrica }\end{array}$ & 100,0 & 100,0 & 100,0 & 100,0 & 100,0 & 99,5 & 99,5 & 100,0 & 100,0 & 99,8 & 100,0 \\
\hline tinham & 6,2 & 8,2 & 9,5 & 13,3 & 10,0 & 8,6 & 12,1 & 22,9 & 26,4 & 27,7 & 34,4 \\
\hline $\begin{array}{l}\text { não tinham } \\
\text { telefone }\end{array}$ & 93,8 & 91,8 & 90,5 & 86,7 & 90,0 & 91,4 & 87,9 & 77,1 & 73,6 & 72,3 & 65,6 \\
\hline tinham & $\ldots$ & $\ldots$ & $\ldots$ & $\ldots$ & $\ldots$ & $\ldots$ & $\ldots$ & 0,7 & 0,4 & 0,4 & 0,6 \\
\hline não tinham & $\ldots$ & $\ldots$ & $\ldots$ & $\ldots$ & $\ldots$ & $\ldots$ & $\ldots$ & 99,3 & 99,6 & 99,6 & 99,4 \\
\hline
\end{tabular}

Fonte: IBGE. Dados básicos das PNAD de 1984 a 1990, 1992, 2993, 1995 e 1996.

Nota: ... Dado numérico não disponivel. 
Tabela A.7.3. Proporção de domicílios particulares permanente, segundo alguns bens duráveis existentes no domicílio urbano; Piaú- 1984 a 1996.

\begin{tabular}{|c|c|c|c|c|c|c|c|c|c|c|c|}
\hline Características & 1984 & 1985 & 1986 & 1987 & 1988 & 1989 & 1990 & 1992 & 1993 & 1995 & 1996 \\
\hline \multicolumn{12}{|l|}{ filtro } \\
\hline tinham & 42,8 & 40,9 & 46,7 & 50,1 & 50,4 & 53,8 & 52,4 & 56,4 & 64,0 & 64,0 & 61,2 \\
\hline não tinham & 57,2 & 59,1 & 53,3 & 49,9 & 49,6 & 46,2 & 47,6 & 43,6 & 36,0 & 36 & 38,8 \\
\hline \multicolumn{12}{|l|}{ fogâa } \\
\hline tinham & 81,9 & 78,1 & 83,4 & 85,3 & 87,8 & 87,7 & 87,8 & 87,6 & 94,3 & 94,3 & 95,4 \\
\hline $\begin{array}{l}\text { não tinham } \\
\text { geladeira }\end{array}$ & 18,1 & 21,9 & 16,6 & 14,7 & 12,2 & 12,3 & 12,2 & 12,4 & 5,7 & 5,7 & 4,6 \\
\hline tinham & 50,2 & 48,0 & 55,4 & 58,0 & 59,0 & 58,9 & 60,7 & 61,2 & 65,2 & 65,2 & 70,7 \\
\hline $\begin{array}{l}\text { não tinham } \\
\text { rádio }\end{array}$ & 49,8 & 52 & 44,6 & 42,0 & 41,0 & 41,1 & 39,3 & 38,8 & 34,8 & 34,8 & 29,3 \\
\hline tinham & $\ldots$ & $\ldots$ & $\ldots$ & $\ldots$ & 67,9 & 67,2 & 67,7 & 69,5 & 78,6 & 78,6 & 83,1 \\
\hline $\begin{array}{l}\text { não tinham } \\
\text { televisão }\end{array}$ & $\ldots$ & $\ldots$ & $\ldots$ & $\ldots$ & 32,1 & 32,8 & 32,3 & 30,5 & 21,4 & 21,4 & 16,9 \\
\hline tinham & $\ldots$ & $\ldots$ & $\ldots$ & $\ldots$ & 59,5 & 61,1 & 64,6 & 64,1 & 66,0 & 75,4 & 81,5 \\
\hline $\begin{array}{l}\text { não tinham } \\
\text { freezer }\end{array}$ & $\ldots$ & $\cdots$ & $\ldots$ & $\ldots$ & 40,5 & 38,9 & 35,4 & 35,9 & 34,0 & 24,6 & 18,5 \\
\hline tinham & $\cdots$ & $\ldots$ & $\ldots$ & $\ldots$ & $\ldots$ & $\ldots$ & $\ldots$ & 7,3 & 5,4 & 5,4 & 8,0 \\
\hline $\begin{array}{l}\text { não tinham } \\
\text { máquina de lavar }\end{array}$ & $\ldots$ & $\cdots$ & $\ldots$ & ... & $\ldots$ & $\ldots$ & $\ldots$ & 92,7 & 94,6 & 94,6 & 92,0 \\
\hline tinham & $\ldots$ & $\ldots$ & $\ldots$ & $\ldots$ & $\ldots$ & $\ldots$ & $\ldots$ & 3,6 & 2,2 & 2,1 & 5,5 \\
\hline não tinham & $\ldots$ & $\ldots$ & $\ldots$ & $\ldots$ & $\ldots$ & $\ldots$ & $\ldots$ & 96,4 & 97,8 & 97,9 & 94,5 \\
\hline
\end{tabular}

Fonte: IBGE. Dados básicos das PNAD de 1984 a 1990, 1992, 2993, 1995 e 1996

Nota: Dado numérico não disponivel.

Tabela A.7.4 Proporção de domicílios particulares permanente, segundo alguns bens duráveis existentes no domicílio rural; Piauí- 1984 a 1996.

\begin{tabular}{|c|c|c|c|c|c|c|c|c|c|c|c|}
\hline Características & 1984 & 1985 & 1986 & 1987 & 1988 & 1989 & 1990 & 1992 & 1993 & 1995 & 1996 \\
\hline $\begin{array}{l}\text { filtro } \\
\text { tinham }\end{array}$ & 14,2 & 16,3 & 15,7 & 13,3 & 15,8 & 14,8 & 15,5 & 21,3 & 22,4 & 29,8 & 24,2 \\
\hline $\begin{array}{l}\text { não tinham } \\
\text { fogão }\end{array}$ & 85,8 & 83,7 & 84,3 & 86,7 & 84,2 & 85,2 & 84,5 & 78,7 & 77,6 & 70,2 & 75,8 \\
\hline tinham & 40,2 & 40,2 & 41,2 & 51,2 & 65,5 & 52,8 & 55,1 & 69,4 & 76,9 & 81,9 & 77,7 \\
\hline $\begin{array}{l}\text { não tinham } \\
\text { geladeira }\end{array}$ & 59,8 & 59,8 & 58,8 & 48,8 & 34,5 & 47,2 & 44,9 & 30,6 & 23,1 & 18,1 & 22,3 \\
\hline tinham & 2,7 & 3,7 & 4,3 & 4,5 & 5,6 & 3,7 & 6,7 & 11,4 & 10,2 & 13,3 & 16,6 \\
\hline $\begin{array}{l}\text { não tinham } \\
\text { rádio }\end{array}$ & 97,3 & 96,3 & 95,7 & 95,5 & 94,4 & 96,3 & 93,3 & 88,6 & 89,8 & 86,7 & 83,4 \\
\hline tinham & $\cdots$ & $\ldots$ & $\ldots$ & $\ldots$ & 61,6 & 63,4 & 66,5 & 63,7 & 59,7 & 72,1 & 70,6 \\
\hline $\begin{array}{l}\text { não tinham } \\
\text { televisão }\end{array}$ & $\ldots$ & $\ldots$ & $\ldots$ & $\ldots$ & 38,4 & 36,6 & 33,5 & 36,3 & 40,3 & 27,9 & 29,4 \\
\hline tinham & $\ldots$ & $\ldots$ & $\ldots$ & $\ldots$ & 4,0 & 4,4 & 5,9 & 11,4 & 14,0 & 17,9 & 22,8 \\
\hline $\begin{array}{l}\text { não tinham } \\
\text { freezer }\end{array}$ & $\ldots$ & $\ldots$ & $\ldots$ & $\ldots$ & 96,0 & 95,6 & 94,1 & 88,6 & 86,0 & 82,1 & 77,4 \\
\hline tinham & $\ldots$ & $\cdots$ & $\cdots$ & $\cdots$ & $\ldots$ & $\ldots$ & $\ldots$ & 1,3 & 0,4 & 0,8 & 1,0 \\
\hline $\begin{array}{l}\text { não tinham } \\
\text { máquina de lavar }\end{array}$ & $\ldots$ & $\ldots$ & $\ldots$ & $\ldots$ & $\ldots$ & $\ldots$ & $\ldots$ & 98,7 & 99,6 & 99,2 & 99,0 \\
\hline $\begin{array}{l}\text { tinham } \\
\text { não tinham }\end{array}$ & $\ldots$ & $\begin{array}{l}\ldots \\
\ldots\end{array}$ & $\begin{array}{l}\ldots \\
\ldots\end{array}$ & $\begin{array}{l}\ldots \\
\ldots\end{array}$ & $\ldots$ & $\begin{array}{l}\ldots \\
\ldots\end{array}$ & $\begin{array}{l}\ldots \\
\ldots\end{array}$ & $\begin{array}{r}0,9 \\
99,1 \\
\end{array}$ & $\begin{array}{r}1,6 \\
98,4 \\
\end{array}$ & $\begin{array}{r}3,5 \\
96,5 \\
\end{array}$ & $\begin{array}{r}0,2 \\
99,8 \\
\end{array}$ \\
\hline
\end{tabular}

Fonte: IBGE. Dados básicos das PNAD de 1984 a 1990, 1992, 2993, 1995 e 1996.

Nota: Dado numérico não disponível. 


\section{APENDICE 8}

Tabela A.8. Inflação e salário mínimo nos meses de referência das PNAD, no período de 1984 a 1996.

\begin{tabular}{l|c|c|c|c|c|c}
\hline \multicolumn{1}{c|}{ ANO } & MES & INPC (1) & SM CORRENTE & SM REAL (2) & $\begin{array}{c}\text { INFLACCÃO } \\
\text { MENSAL \% (3) }\end{array}$ & $\begin{array}{c}\text { IPC-Teresina \% } \\
(4)\end{array}$ \\
\hline 1984 & setembro & 16,242 & 97176 & 598,30 & 11,1 & 11,8 \\
1985 & setembro & 51,423 & 333120 & 647,80 & 10,1 & 11,3 \\
$1986(5)$ & setembro & 106,15 & 804 & 757,42 & 1,2 & 1,9 \\
$1987(6)$ & setembro & 406,24 & 2400 & 590,78 & 7,2 & 7,3 \\
1988 & setembro & 3093,61 & 18960 & 612,88 & 26,9 & 27,1 \\
$1989(7)$ & setembro & 40639,85 & 249,48 & 613,88 & 36,3 & 37,6 \\
$1990(8)$ & setembro & 1339050 & 6056,31 & 452,28 & 14,3 & 15,6 \\
$1992(9)$ & setembro & $78806,6.10^{3}$ & 522186,94 & 662,62 & 24,0 & 27,9 \\
1993 & setembro & $1580,16.10^{6}$ & 9606 & 607,91 & 35,6 & 35,7 \\
$1995(10)$ & setembro & $47638,39.10^{6}$ & 100 & 577,27 & 1,17 & 1,0 \\
1996 & setembro & $53820,06.10^{6}$ & 112 & 572,27 & 0,02 & 0,62 \\
\hline
\end{tabular}

Fonte: Dados extraídos de Hoffimann $(1995$, p.2), exclusive a última coluna.

(1) Com base em março de 1986.

(2) Em valores reais deflacionados pelo INPC com base em março de 1986.

(3) Acréscimo percentual do INPC no mês de referência em relação ao mês anterior. No caso de 1982 considerou-se a raiz quadrada da relação entre o INPC de nov. E o INPC de set.

(4) Indice de Preços ao Consumidor (Custo de Vida)-Teresina, variação percentual mensal. Fundação CEPRO/Departamento de Estatística e Informática. A variação de setembro de 1989 foi considerado o valor de

$$
\frac{363}{\frac{269+143}{2}}=\frac{x}{\frac{27,10+1554}{2}} \text {. }
$$

em virtude da paralisação da elaboração do IPC-Teresina por problemas administrativos e financeiros da Fundação CEPRO, retomando apenas em junho/ $/ 90$.

(5) Plano Cruzado em 01.03.86.

(6) Plano Cruzado II ( Bresser) em 15.06.87

(7) Plano Verão em 15.04.89.

(8) Plano Brasil Novo (Plano Collor I) em 15.03.90.

(9) Plano Collor II em 31.01.91.

(10) Plano Real em 01.07.94 


\section{APENDICE 9}

Tabela A.9. Equações ajustadas e coeficientes de determinação para explicar as variações de $P(\text { ou } H)^{(1)}$, em função de $\mu$ e $\mu^{2}$, e de $G$ e $G^{2}$. Piauí 1984 a 1990, 1992, 1993 e 1996.

\begin{tabular}{|c|c|}
\hline Equações Ajustadas & $\begin{array}{l}\text { Coeficiente de determinação } \\
\left(\mathrm{R}^{2}\right) \text {, em } \%\end{array}$ \\
\hline $\begin{array}{c}P=-0,240-0,381 \mu+0,046 \mu^{2}+2,651 G-1,294 G^{2} \\
(-2,791)^{*} \quad(0,844) \quad(1,179) \quad(-0,719)\end{array}$ & 99,79 \\
\hline $\begin{array}{r}P=0,206-0,269 \mu+1,018 G \\
(-30,585)^{*}(20,956)\end{array}$ & 99,75 \\
\hline 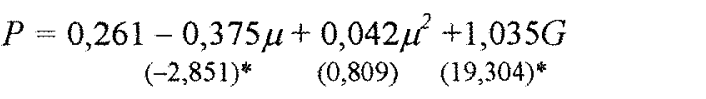 & 99,77 \\
\hline $\begin{array}{c}P=0,436+0,482 \mu-0,334 \mu^{2} \\
(0,565) \quad(-1,008)\end{array}$ & 87,65 \\
\hline$P=-8,194+\underset{(1,371) \quad(-1,273)}{26,225 G-19,623 G^{2}}$ & 75,58 \\
\hline $\begin{array}{c}H=0,748-0,257 \mu+0,449 G \\
(-7,835) \quad(2,479)\end{array}$ & 94,45 \\
\hline $\begin{array}{c}H=0,728-0,220 \mu-0,015 \mu^{2}+0,444 G \\
(-0,429) \quad(-0,072) \quad(2,123)^{*}\end{array}$ & 94,46 \\
\hline
\end{tabular}

Notas: Medidas de pobreza calculadas com linha de pobreza igual a 1 SM ago./80 Teste $t$ entre parênteses.

Os coeficientes assinalados são estatisticamente significativos ao nivel de $5 \%$ 


\section{APÊNDICE 10}

Tabela A.10. Equações ajustadas e coeficientes de determinação para explicar as variações de $P$ (ou $F G T)^{(1)}$, em função de $\mu$ e $\mu^{2}, \Psi^{(2)}$ e de e $s m^{(3)}$; Piauí - 1984 a 1990, 1992, 1993, 1995 e 1996

\begin{tabular}{|c|c|}
\hline Equações Ajustadas & $\begin{array}{l}\text { Coeficiente de determinação } \\
\left(\mathrm{R}^{2}\right), \text { em } \%\end{array}$ \\
\hline $\begin{array}{cccc}P=0,188+1,033 G & -0,273 \mu & -0,010 \Psi+0,00002 s m \\
(19,672) & (-28,926)^{*} & (-0,769) & (1,193)\end{array}$ & $99,81 \%$ \\
\hline 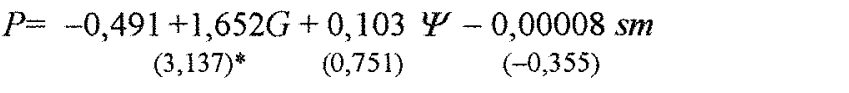 & 73,14 \\
\hline$P=-0,619+\underset{(4,360)^{*}}{1,866-0,00007} \mathrm{sm}$ & 70,97 \\
\hline $\begin{array}{c}F G T=-0,096+0,978 G-0,201 \mu-0,024) \Psi-0,00003 s m \\
(11,519)^{*} \quad(-13,224)^{*} \quad(-1,111) \\
(0,874)\end{array}$ & 99,23 \\
\hline 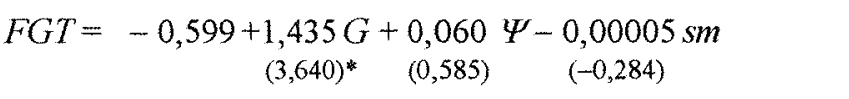 & 76,84 \\
\hline $\begin{array}{c}F G T=-0,672+1,560 G-0,00004 \mathrm{sm} \\
(4,917)^{*} \quad(-0,249)\end{array}$ & 75,71 \\
\hline
\end{tabular}

Notas: Teste $t$ entre parênteses.

Os coeficientes assinalados são estatisticamente significativos ao nivel de $5 \%$.

(1) Medidas de pobreza calculadas com linha de pobreza igual a 1 SM ago./80

(2) Considerou-se a variação mensal do Indice Nacional de Preço ao Consumidor (INPC)

(3) Salário minimo teal deflacionado pelo INPC de março de 1996. 


\section{APÊNDICE 11}

Tabela A.11. Equações ajustadas e coeficientes de determinação para explicar as variações de $\mathrm{G}$, em função de $\mu$ e $\mu^{2}$, de $\Psi$ e $s m$. Piauí - 1984 1996

\begin{tabular}{|c|c|}
\hline Equações Ajustadas & $\begin{array}{l}\text { Coeficiente de } \\
\text { determinação } \\
\left(\mathrm{R}^{2}\right) \text {, em } \%\end{array}$ \\
\hline $\begin{array}{c}G=0,715-0,073 \mu+0,088 \Psi-0,00002 s m \\
(-1,179) \\
(0,994) \\
(-0,164)\end{array}$ & 42,04 \\
\hline $\begin{array}{c}G=0,171+0,759 \mu-0,332 \mu^{2}+0,042 \Psi+0,00004 \mathrm{sm} \\
(0,616) \quad(-0,671) \quad(0,364)\end{array}$ & 46,08 \\
\hline $\begin{array}{c}G=0,638+0,141 \Psi-0,00006 s m \\
(1,827) \quad(-0,421)\end{array}$ & 54,85 \\
\hline $\begin{array}{c}G=0,703-0,075 \mu+0,086 \mathrm{sm} \\
(-1,328) \quad(1,047)\end{array}$ & 41,81 \\
\hline $\begin{array}{c}G=0,758-0,105 \mu-0,000008 \Psi \\
(-1,977) \quad(-0,053)\end{array}$ & 33,86 \\
\hline
\end{tabular}

Notas: Medidas de pobreza calculadas com linha de pobreza igual a 1 SM ago./80 


\section{APÊNDICE 12}

Tabela A.12.1. Coordenadas de pontos das curvas de Lorenz (em \% da renda) para PEA com rendimento; Piauí -1992, 1993 e 1995.

\begin{tabular}{c|c|c|c}
\hline FRAÇÃO DA POPULAÇÃO & 1992 & 1993 & 1995 \\
\hline 10 & 0,6 & 0,6 & 0,8 \\
20 & 1,9 & 1,8 & 2,8 \\
30 & 4,0 & 4,1 & 5,7 \\
40 & 7,1 & 7,7 & 10,1 \\
50 & 11,5 & 12,6 & 14,8 \\
60 & 18,3 & 17,8 & 20,3 \\
70 & 26,1 & 25,0 & 27,4 \\
80 & 36,0 & 34,7 & 37,0 \\
90 & 50,5 & 49,4 & 51,9 \\
95 & 62,2 & 61,6 & 64,3 \\
99 & 83,9 & 82,0 & 84,6 \\
100,0 & 100,0 & 100,0 & 100,0 \\
\hline
\end{tabular}

Fonte: IBGE. Microdados das PNAD 1992, 1993 e 1995.

Tabela A.12.2. Coordenadas de pontos das curvas de Lorenz (em \% da renda) para PEA com rendimento no domicílio urbano; Piauí -1992, 1993 e 1995.

\begin{tabular}{c|c|c|c}
\hline FRAC̆̃̃O DA POPULAC̆̊̃O & 1992 & 1993 & 1995 \\
\hline 10 & 0,5 & 0,6 & 1,1 \\
20 & 1,9 & 1,8 & 3,2 \\
30 & 4,1 & 4,1 & 6,7 \\
40 & 7,3 & 7,7 & 10,3 \\
50 & 12,5 & 12,6 & 14,8 \\
60 & 18,4 & 17,8 & 20,3 \\
70 & 25,6 & 24,9 & 27,9 \\
80 & 35,2 & 34,7 & 38,5 \\
90 & 49,5 & 49,4 & 54,7 \\
95 & 62,3 & 61,6 & 68,7 \\
99 & 85,3 & 82 & 88,5 \\
100,0 & 100,0 & 100,0 & 100,0 \\
\hline
\end{tabular}

Fonte: IBGE. Microdados das PNAD 1992, 1993 e 1995.

Tabela A.12.3. Coordenadas de pontos das curvas de Lorenz (em \% da renda) para PEA com rendimento no domicílio rural; Piauí -1992, 1993 e 1995.

\begin{tabular}{c|c|c|c}
\hline FRAÇÃO DA POPULAÇÃO & 1992 & 1993 & 1995 \\
\hline 10 & 0,8 & 0,8 & 0,9 \\
20 & 2,5 & 2,8 & 2,8 \\
30 & 5,1 & 5,6 & 6,1 \\
40 & 8,9 & 9,6 & 10,5 \\
50 & 14,0 & 15,1 & 16,9 \\
60 & 20,8 & 22,7 & 24,5 \\
70 & 30,9 & 32,4 & 32,4 \\
80 & 44,0 & 42,5 & 42,7 \\
90 & 61,0 & 56,2 & 56,0 \\
95 & 72,9 & 66,1 & 65,1 \\
99 & 88,1 & 81,4 & 76,5 \\
100,0 & 100,0 & 100,0 & 100,0 \\
\hline
\end{tabular}




\section{APÊNDICE 13}

Tabela A.13.1. Distribuição do rendimento da população economicamente ativa, conforme situação do domicílio urbano; Piauí - 1992, 1993 e 1995.

\begin{tabular}{c|c|c|c|c|c|c}
\hline \multirow{2}{*}{$\begin{array}{c}\% \\
\text { acumulado pessoas }\end{array}$} & \multicolumn{2}{|c|}{1992} & \multicolumn{2}{c}{1993} & \multicolumn{2}{c}{1995} \\
\cline { 2 - 7 } & $\begin{array}{c}\text { percentis } \\
\text { (limite superior) }\end{array}$ & $\begin{array}{c}\text { rendimento } \\
\text { médio do estrato }\end{array}$ & $\begin{array}{c}\text { percentis } \\
\text { (limite superior) }\end{array}$ & $\begin{array}{c}\text { rendimento } \\
\text { médio do estrato }\end{array}$ & $\begin{array}{c}\text { percentis } \\
\text { (limite superior) }\end{array}$ & $\begin{array}{c}\text { rendimento médio } \\
\text { do estrato }\end{array}$ \\
\hline 10 & 0,123 & 0,076 & 0,138 & 0,087 & 0,349 & 0,204 \\
20 & 0,230 & 0,180 & 0,253 & 0,192 & 0,359 & 0,394 \\
30 & 0,384 & 0,304 & 0,410 & 0,340 & 0,699 & 0,643 \\
40 & 0,614 & 0,446 & 0,730 & 0,562 & 0,699 & 0,699 \\
50 & 0,802 & 0,726 & 0,736 & 0,735 & 0,978 & 0,814 \\
60 & 0,861 & 0,812 & 0,919 & 0,802 & 1,118 & 1,048 \\
70 & 1,124 & 0,994 & 1,244 & 1,076 & 1,684 & 1,399 \\
80 & 1,588 & 1,321 & 1,774 & 1,501 & 2,375 & 1,977 \\
90 & 2,758 & 1,971 & 2,943 & 2,231 & 3,947 & 3,022 \\
95 & 5,375 & 3,534 & 4,825 & 3,742 & 6,420 & 5,234 \\
99 & 13,214 & 7,947 & 13,512 & 7,748 & 14,307 & 9,241 \\
100 & & 20,315 & & 27,476 & & 21,466 \\
\hline
\end{tabular}

Fonte: IBGE. Microdados das PNAD de 1992, 1993 e 1995.

Nota: O percentil é dado em unidades de valor real igual ao maior salário minimo vigente em agosto de 1980 (utilizando o INPC restrito como deflator).

Tabela A.13.2. Distribuição do rendimento da população economicamente ativa no domicílio rural; Piauí - 1992, 1993 e 1995.

\begin{tabular}{c|c|c|c|c|c|c}
\hline \multirow{2}{*}{$\begin{array}{c}\% \text { acumulado } \\
\text { de pessoas }\end{array}$} & $\begin{array}{c}\text { percentis } \\
\text { (limite superior) }\end{array}$ & $\begin{array}{c}\text { rendimento } \\
\text { médio do estrato }\end{array}$ & $\begin{array}{c}\text { percentis } \\
\text { (imite superior) }\end{array}$ & $\begin{array}{c}\text { rendimento } \\
\text { médio do } \\
\text { estrato }\end{array}$ & $\begin{array}{c}\text { percentis } \\
\text { (limite superior) }\end{array}$ & $\begin{array}{c}\text { rendimento } \\
\text { médio do } \\
\text { estrato }\end{array}$ \\
\hline 10 & 0,077 & 0,048 & 0,103 & 0,064 & 0,140 & 0,082 \\
20 & 0,138 & 0,111 & 0,191 & 0,146 & 0,231 & 0,176 \\
30 & 0,200 & 0,168 & 0,230 & 0,212 & 0,349 & 0,297 \\
40 & 0,284 & 0,238 & 0,356 & 0,304 & 0,489 & 0,406 \\
50 & 0,384 & 0,325 & 0,461 & 0,413 & 0,685 & 0,586 \\
60 & 0,510 & 0,432 & 0,728 & 0,578 & 0,699 & 0,698 \\
70 & 0,768 & 0,649 & 0,736 & 0,736 & 0,838 & 0,727 \\
80 & 0,921 & 0,836 & 0,851 & 0,760 & 1,048 & 0,945 \\
90 & 1,321 & 1,085 & 1,329 & 1,043 & 1,397 & 1,218 \\
95 & 1,723 & 1,518 & 1,731 & 1,491 & 1,935 & 1,664 \\
99 & 3,839 & 2,422 & 5,055 & 2,895 & 5,246 & 2,619 \\
100 & 7,581 & & 14,060 & & 21,552 \\
\hline
\end{tabular}

Fonte: IBGE. Microdados das PNAD de 1992, 1993 e 1995.

Nota: O percentil é dado em unidades de valor real igual ao maior salário mínimo vigente em agosto de 1980 (utilizando o INPC restrito como deflator). 


\section{APÊNDICE 14}

Tabela A.14. Medidas de desigualdade conforme distribuição da renda entre as pessoas economicamente ativas com rendimento nos Estados Nordestinos $1992,1993,1995$ e 1996.

\begin{tabular}{|c|c|c|c|c|c|c|c|c|}
\hline \multicolumn{2}{|c|}{ ESTADOS } & $\begin{array}{l}\text { NUMMERO } \\
\text { DE } \\
\text { PESSOAS }\end{array}$ & $\begin{array}{l}\text { RENDIMENTO } \\
\text { MÉDIO (1) }\end{array}$ & $\begin{array}{l}\text { INDICE } \\
\text { DE GINI }\end{array}$ & $\begin{array}{l}\text { INDICE } \\
\text { DE THEL }\end{array}$ & $\begin{array}{l}50 \% \\
\text { POBRES }\end{array}$ & $\begin{array}{ll}10 \% & \text { MAIS } \\
\text { RICOS } & \\
\end{array}$ & $\begin{array}{l}5 \% \text { MAIS } \\
\text { RICOS }\end{array}$ \\
\hline & 1992 & 1.397 .843 & 1,02 & 0,564 & 0,463 & 13,9 & 43,7 & 30,4 \\
\hline & 1993 & 1.760 .497 & 1,09 & 0,659 & 0,617 & 9,5 & 54,5 & 41,8 \\
\hline & 1995 & 1.796 .621 & 1,37 & 0,591 & 0,526 & 13,8 & 49,1 & 35,7 \\
\hline & 1996 & 1.899 .560 & 1,56 & 0,617 & 0,613 & 12,7 & 51,5 & 38,9 \\
\hline \multirow[t]{4}{*}{ PI } & 1992 & 789.498 & 1,10 & 0,610 & 0,555 & 11,9 & 49,5 & 37,8 \\
\hline & 1993 & 887.623 & 1,23 & 0,613 & 0,593 & 13,0 & 50,8 & 39,1 \\
\hline & 1995 & 917.977 & 1,48 & 0,580 & 0,524 & 14,7 & 48,1 & 35,8 \\
\hline & 1996 & 886.295 & 1,50 & 0,567 & 0,474 & 14,8 & 46,1 & 31,7 \\
\hline \multirow[t]{4}{*}{$\mathrm{CE}$} & 1992 & 2.141 .267 & 1,27 & 0,599 & 0,535 & 13,1 & 48,9 & 36,3 \\
\hline & 1993 & 2.206 .871 & 1,39 & 0,627 & 0,605 & 12,2 & 52,6 & 40,7 \\
\hline & 1995 & 2.409 .383 & 1,80 & 0,603 & 0,569 & 13,4 & 51,4 & 38,8 \\
\hline & 1996 & 2.305 .549 & 1,82 & 0,601 & 0,567 & 13,5 & 51,3 & 38,6 \\
\hline \multirow[t]{4}{*}{ RN } & 1992 & 899.485 & 1,43 & 0,624 & 0,575 & 12,5 & 53,3 & 39,9 \\
\hline & 1993 & 871.194 & 1,39 & 0,602 & 0,537 & 13,8 & 50,8 & 37,2 \\
\hline & 1995 & 949.765 & 1,94 & 0,590 & 0,541 & 14,2 & 50,8 & 36,9 \\
\hline & 1996 & 943.087 & 2,09 & 0,587 & 0,524 & 14,4 & 50,6 & 36,4 \\
\hline \multirow[t]{4}{*}{ PB } & 1992 & 1.071 .624 & 1,23 & 0,611 & 0,529 & 11,9 & 49,8 & 36,1 \\
\hline & 1993 & 1.114 .481 & 1,52 & 0,664 & 0,642 & 10,6 & 57,1 & 44,1 \\
\hline & 1995 & 1.180 .775 & 1,98 & 0,610 & 0,575 & 13,4 & 52,8 & 40,3 \\
\hline & 1996. & 1.163 .914 & 1,87 & 0,604 & 0,559 & 13,7 & 52,0 & 39,1 \\
\hline \multirow[t]{4}{*}{$\mathrm{PE}$} & 1992 & 2.458 .310 & 1,46 & 0,582 & 0,513 & 14,2 & 47,4 & 34,6 \\
\hline & 1993 & 2.420 .950 & 1,50 & 0,624 & 0,585 & 12,5 & 52,6 & 39,9 \\
\hline & 1995 & 2.518 .368 & 2,01 & 0,567 & 0,518 & 15,4 & 48,4 & 35,8 \\
\hline & 1996 & 2.475 .598 & 2,08 & 0,577 & 0,525 & 14,6 & 48,7 & 36,1 \\
\hline \multirow[t]{4}{*}{$\mathrm{AI}$} & 1992 & 885.741 & 1,48 & 0,574 & 0,491 & 14,5 & 46,3 & 33,6 \\
\hline & 1993 & 823.921 & 1,50 & 0,612 & 0,551 & 12,8 & 51,5 & 38,0 \\
\hline & 1995 & 903.742 & 2,13 & 0,621 & 0,598 & 13,1 & 54,9 & 41,8 \\
\hline & 1996 & 823.197 & 2,26 & 0,610 & 0,585 & 13,3 & 52,1 & 39,8 \\
\hline \multirow[t]{4}{*}{$\mathrm{SE}$} & 1992 & 555.165 & 1,46 & 0,577 & 0,500 & 14,6 & 47,7 & 34,1 \\
\hline & 1993 & 548.383 & 1,74 & 0,642 & 0,688 & 12,1 & 55,6 & 43,9 \\
\hline & 1995 & 537.341 & 1,88 & 0,574 & 0,499 & 14,5 & 48,3 & 34,9 \\
\hline & 1996 & 588.583 & 2,09 & 0,598 & 0,575 & 14,0 & 52,5 & 39,8 \\
\hline \multirow[t]{4}{*}{$\mathrm{BA}$} & 1992 & 3.911 .040 & 1,51 & 0,576 & 0,514 & 14,7 & 47,2 & 34,8 \\
\hline & 1993 & 4.030 .282 & 1,70 & 0,636 & 0,617 & 12,1 & 54,3 & 41,7 \\
\hline & 1995 & 4.332 .491 & 1,88 & 0,580 & 0,567 & 14,8 & 50,0 & 38,0 \\
\hline & 1996 & 4.028 .628 & 2,09 & 0,600 & 0,579 & 13,7 & 51,4 & 39,2 \\
\hline
\end{tabular}

Fonte: BBGE. Dados básicos das PNAD de 1992, 1993, 1995 e 1996.

(1) Em unidades igual a 1 SM ago./80. 


\section{APÊNDICE 15}

Tabela A.15. Medidas de pobreza conforme distribuição da renda entre as pessoas economicamente ativas com rendimento nos Estados Nordestinos; 1992, 1993, 1995 e 1996.

\begin{tabular}{|c|c|c|c|c|c|c|c|}
\hline \multicolumn{2}{|c|}{ ESTADOS } & \multirow{2}{*}{$\begin{array}{c}\text { NÚMERO } \\
\text { DE POBRES } \\
991.730\end{array}$} & \multirow{2}{*}{$\begin{array}{c}\text { PROPORCÃO } \\
\text { DE POBRES }(\mathrm{H}) \\
0709\end{array}$} & $\begin{array}{c}\text { RAZÃODE } \\
\text { INSUFICIÊNCIA } \\
\text { DE RENDA (I) }\end{array}$ & $\begin{array}{l}\text { WNDICE DE } \\
\text { SEN }(P)\end{array}$ & \multirow{2}{*}{$\frac{r(\%)(1)}{39,5}$} & \multirow{2}{*}{$\begin{array}{l}\text { INDICE } \\
\text { DE FGT } \\
0,284\end{array}$} \\
\hline MA & 1992 & & & 0,568 & 0,517 & & \\
\hline & 1993 & 1.317 .730 & 0,748 & 0,623 & 0,584 & 42,9 & 0,348 \\
\hline & 1995 & 1.155 .795 & 0,643 & 0,529 & 0,431 & 24,8 & 0,219 \\
\hline & 1996 & 1.204 .159 & 0,634 & 0,513 & 0,415 & 20,8 & 0,205 \\
\hline \multirow[t]{4}{*}{ PI } & 1992 & 563.111 & 0,713 & 0,577 & 0,530 & 37,5 & 0,298 \\
\hline & 1993 & 626.484 & 0,706 & 0,547 & 0,498 & 31,4 & 0,265 \\
\hline & 1995 & 570.678 & 0,622 & 0,487 & 0,390 & 20,4 & 0,186 \\
\hline & 1996 & 547.583 & 0,618 & 0,478 & 0,381 & 19,7 & 0,178 \\
\hline \multirow[t]{4}{*}{$\mathrm{CE}$} & 1992 & 1.438 .977 & 0,672 & 0,541 & 0,474 & 28,7 & 0,252 \\
\hline & 1993 & 1.472 .826 & 0,667 & 0,539 & 0,469 & 25,9 & 0,248 \\
\hline & 1995 & 1.358 .105 & 0,564 & 0,469 & 0,337 & 14,7 & 0,154 \\
\hline & 1996 & 1.310 .261 & 0,568 & 0,457 & 0,334 & 14,3 & 0,149 \\
\hline \multirow[t]{4}{*}{$\mathrm{RN}$} & 1992 & 603.881 & 0,671 & 0,518 & 0,458 & 24,3 & 0,235 \\
\hline & 1993 & 594.242 & 0,682 & 0,503 & 0,446 & 24,6 & 0,220 \\
\hline & 1995 & 512.663 & 0,540 & 0,420 & 0,292 & 11,7 & 0,121 \\
\hline & 1996 & 474.534 & 0,503 & 0,397 & 0,263 & 9,6 & 0,105 \\
\hline \multirow[t]{4}{*}{$\mathrm{PB}$} & 1992 & 728.762 & 0,680 & 0,566 & 0,498 & 31,3 & 0,276 \\
\hline & 1993 & 770.820 & 0,692 & 0,542 & 0,487 & 24,6 & 0,259 \\
\hline & 1995 & 636.024 & 0,539 & 0,441 & 0,308 & 12,0 & 0,135 \\
\hline & 1996 & 662.405 & 0,569 & 0,435 & 0,326 & 13,2 & 0,142 \\
\hline \multirow[t]{4}{*}{ PE } & 1992 & 1.504 .122 & 0,612 & 0,499 & 0,404 & 20,9 & 0,200 \\
\hline & 1993 & 1.577 .180 & 0,651 & 0,517 & 0,441 & 22,4 & 0,225 \\
\hline & 1995 & 1.214 .037 & 0,482 & 0,396 & 0,246 & 9,5 & 0,097 \\
\hline & 1996 & 1.225 .469 & 0,495 & 0,394 & 0,255 & 9,4 & 0,100 \\
\hline \multirow[t]{4}{*}{$\mathrm{AL}$} & 1992 & 548.747 & 0,620 & 0,486 & 0,395 & 20,3 & 0,189 \\
\hline & 1993 & 527.051 & 0,640 & 0,520 & 0,429 & 22,2 & 0,217 \\
\hline & 1995 & 502.052 & 0,556 & 0,406 & 0,285 & 10,6 & 0,113 \\
\hline & 1996 & 437.035 & 0,531 & 0,378 & 0,258 & 8,9 & 0,096 \\
\hline \multirow[t]{4}{*}{$S E$} & 1992 & 349.670 & 0,630 & 0,480 & 0,400 & 20,7 & 0,191 \\
\hline & 1993 & 341.892 & 0,623 & 0,493 & 0,399 & 17,6 & 0,192 \\
\hline & 1995 & 279.406 & 0,520 & 0,436 & 0,290 & 12,1 & 0,124 \\
\hline & 1996 & 307.968 & 0,523 & 0,400 & 0,264 & 10,0 & 0,103 \\
\hline \multirow[t]{4}{*}{$\mathrm{BA}$} & 1992 & 2.403 .528 & 0,615 & 0,477 & 0,386 & 19,5 & 0,182 \\
\hline & 1993 & 2.552 .769 & 0,633 & 0,497 & 0,410 & 18,6 & 0,199 \\
\hline & 1995 & 2.284 .781 & 0,527 & 0,422 & 0,281 & 11,8 & 0,116 \\
\hline & 1996 & 2.125 .661 & 0,528 & 0,410 & 0,275 & 10,4 & 0,110 \\
\hline
\end{tabular}

Fonte: BBGE. Dados básicos das PNAD de 1992, 1993, 1995 e 1996.

(1) Insuficiência da renda como porcentagem da renda total. 


\section{APÊNDICE 16}

Tabela A.16. Coeficientes da equação de regressão ajustada (em logs), conforme situação do domicílio urbano; Piauí- 1992, 1993 e 1995.

\begin{tabular}{|c|c|c|c|}
\hline FATORES & 1992 & 1993 & 1995 \\
\hline \multicolumn{4}{|l|}{ SEXO } \\
\hline Homem & $0,699 *$ & $0,481 *$ & $0,464 *$ \\
\hline Mulher & 0,000 & 0,000 & 0,000 \\
\hline \multicolumn{4}{|l|}{ IDADE } \\
\hline 10 a 14 anos & 0,000 & 0,000 & 0,000 \\
\hline 15 a 17 anos & 0,059 & 0,163 & 0,244 \\
\hline 18 a 19 anos & 0,339 & $0,557^{*}$ & $0,427^{*}$ \\
\hline 20 a 24 anos & $0,472^{*}$ & $0,650^{*}$ & $0,516^{*}$ \\
\hline 25 a 29 anos & $0,615^{*}$ & $0,903^{*}$ & $0,807^{*}$ \\
\hline 30 a 39 anos & $0,768^{*}$ & $1,014^{*}$ & $0,906^{*}$ \\
\hline 40 a 49 anos & $1,016^{*}$ & $1,093^{*}$ & $1,115^{*}$ \\
\hline 50 a 59 anos & $1,096^{*}$ & $1,239^{*}$ & $1,171^{*}$ \\
\hline 60 anos ou mais & $1,777^{\text {* }}$ & $2,080^{*}$ & $1,771^{*}$ \\
\hline \multicolumn{4}{|l|}{ ESCOLARIDADE } \\
\hline sem instrução e menos de 1 ano & 0,000 & 0,000 & 0,000 \\
\hline 1 a 4 anos & 0,146 & $0,254^{*}$ & $0,233^{*}$ \\
\hline 5 a 8 anos & $0,363^{*}$ & $0,579 *$ & $0,403^{*}$ \\
\hline 9 a 11 anos & $0,940^{*}$ & $1,000^{*}$ & $0,881 *$ \\
\hline 12 anos ou mais & $1,408^{*}$ & $1,493^{*}$ & $1,569^{*}$ \\
\hline \multicolumn{4}{|c|}{ POSIÇÃO NA OCUPAÇÃO } \\
\hline empregado carteira assinada & 0,000 & 0,000 & 0,000 \\
\hline funcionário público & $-0,091$ & 0,134 & $0,174^{*}$ \\
\hline outros empregados. & $-0,671 *$ & $-0,672^{*}$ & $-0,320^{*}$ \\
\hline doméstica & $-0,845^{*}$ & $-1,038^{*}$ & $-0,380^{*}$ \\
\hline conta própria & $-0,390^{*}$ & $-0,403^{*}$ & $-0,113$ \\
\hline empregadores & 0,261 & $0,503^{*}$ & $0,695^{*}$ \\
\hline \multicolumn{4}{|c|}{ ATIVIDADE DO TRABLHO PRINCIPAL } \\
\hline agricola & 0,000 & 0,000 & 0,000 \\
\hline não-agricola & $0,730^{*}$ & $0,591^{*}$ & $0,689^{*}$ \\
\hline \multicolumn{4}{|c|}{ HORAS DE TRABALHO } \\
\hline até 14 & 0,000 & 0,000 & 0,000 \\
\hline 15 a 39 & $0,734^{*}$ & $0,361^{*}$ & $0,595^{*}$ \\
\hline 40 a 44 & $0,966^{*}$ & $0,623^{*}$ & $0,803^{*}$ \\
\hline 45 a 48 & $0,958^{*}$ & $0,654^{*}$ & $0,879^{*}$ \\
\hline 49 ou mais & $1,002^{*}$ & $0,829^{*}$ & $1,026^{*}$ \\
\hline
\end{tabular}

Fonte: IBGE. Microdados das PNAD de 1992, 1993 e 1995.

Nota: Resultados do Procedure GIM/SAS.

Todos os coeficientes assinalados são estatisticamente significativos ao nivel de $5 \%$. 


\section{APENDICE 17}

Tabela A.17. Coeficientes da equação de regressão ajustada (em logs) situação do domicílio rural; Piauí- 1992, 1993 e 1995.

\begin{tabular}{|c|c|c|c|}
\hline FATORES & 1992 & 1993 & 1995 \\
\hline \multicolumn{4}{|l|}{ SEXO } \\
\hline Homem & $0,921^{*}$ & $0,745^{*}$ & $0,386^{*}$ \\
\hline Mulher & 0,000 & 0,000 & 0,000 \\
\hline \multicolumn{4}{|l|}{ IDADE } \\
\hline 10 a 14 anos & 0,000 & 0,000 & 0,000 \\
\hline 15 a 17 anos & 0,603 & 0,264 & 0,197 \\
\hline 18 a 19 anos & 0,691 & 0,462 & 0,413 \\
\hline 20 a 24 anos & 0,583 & 0,495 & 0,393 \\
\hline 25 a 29 anos & $0,870^{*}$ & 0,454 & $0,617^{*}$ \\
\hline 30 a 39 anos & $1,007^{*}$ & 0,778 & $0,665^{*}$ \\
\hline 40 a 49 anos & $1,262^{*}$ & 0,804 & $0,805^{*}$ \\
\hline 50 a 59 anos & $1,524 *$ & $1,160^{*}$ & $0,868^{*}$ \\
\hline 60 anos ou mais & $2,122^{*}$ & $1,936^{*}$ & $1,965^{*}$ \\
\hline \multicolumn{4}{|l|}{ ESCOLARTDADE } \\
\hline sem instrução e menos de 1 ano & 0,000 & 0,000 & 0,000 \\
\hline 1 a 4 anos & $0,187 *$ & $0,236^{*}$ & 0,090 \\
\hline 5 a 8 anos & 0,222 & $0,371^{*}$ & 0,042 \\
\hline 9 a 11 anos & $1,291 *$ & $0,706^{*}$ & $0,719^{*}$ \\
\hline 12 anos ou mais & $2,422 *$ & $2,960^{*}$ & $2,475^{*}$ \\
\hline \multicolumn{4}{|c|}{ POSIÇÃO NA OCUPAÇÃO } \\
\hline empregado com carteira assinada & 0,000 & 0,000 & 0,000 \\
\hline funcionário público. & 0,578 & 0,134 & 0,005 \\
\hline outros empregados. & $-0,202$ & $-0,341$ & $-0,150$ \\
\hline doméstica & 0,282 & $-0,438$ & $-0,269$ \\
\hline conta própria & $-0,079$ & $-0,270$ & $-0,379^{*}$ \\
\hline empregadores & $0,561 *$ & 0,166 & 0,046 \\
\hline \multicolumn{4}{|c|}{ ATIVIDADE DO TRABLHO PRINCIPAL } \\
\hline agrícola & 0,000 & 0,000 & 0,000 \\
\hline não-agrícola & $0,327^{*}$ & $0,446^{*}$ & $0,422^{*}$ \\
\hline \multicolumn{4}{|l|}{ HORAS DE TRABALHO } \\
\hline ate 14 & 0,000 & 0,000 & 0,000 \\
\hline 15 a 39 & 0,314 & 0,022 & 0,062 \\
\hline 40 a 44 & 0,426 * & 0,448 & 0,175 \\
\hline 45 a 48 & $0,549^{*}$ & $0,636^{*}$ & $0,537^{*}$ \\
\hline 49 ou mais & $0,907^{*}$ & $0,792 *$ & $0,793^{*}$ \\
\hline
\end{tabular}

Fonte: IBGE. Microdados das PNAD de 1992, 1993 e 1995.

Nota: Resultados do Procedure GLM/SAS.

Todos os coeficientes assinalados são estatisticamente significativos ao nível de $5 \%$. 


\section{APENDICE 18}

Tabela A.18. Coeficientes da equação de regressão ajustada (em logs) atividade do trabalho principal agrícola; Piauí- 1992, 1993 e 1995.

\begin{tabular}{|c|c|c|c|}
\hline FATORES & 1992 & 1993 & 1995 \\
\hline \multicolumn{4}{|c|}{ SITUAÇÃO DO DOMTCILIO } \\
\hline urbano & $-0,003$ & $-0,106$ & 0,020 \\
\hline \multirow{2}{*}{\multicolumn{4}{|c|}{ SEXO }} \\
\hline & & & \\
\hline Homem & $0,670^{*}$ & $0,680^{*}$ & 0,115 \\
\hline Mulher & 0,000 & 0,000 & 0,000 \\
\hline \multicolumn{4}{|l|}{ IDADE } \\
\hline 10 a 14 anos & 0,000 & 0,000 & 0,000 \\
\hline 15 a 17 anos & 0,400 & 0,219 & 0,117 \\
\hline 18 a 19 anos & 0,690 & 0,556 & 0,159 \\
\hline 20 a 24 anos & 0,479 & 0,425 & 0,127 \\
\hline 25 a 29 anos & $0,855^{*}$ & $0,761^{*}$ & 0,341 \\
\hline 30 a 39 anos & $0,917^{*}$ & $0,893^{*}$ & 0,434 \\
\hline 40 a 49 anos & $1,387^{*}$ & $0,833^{*}$ & $0,752^{*}$ \\
\hline 50 a 59 anos & $1,402^{*}$ & $1,096^{*}$ & $0,834^{*}$ \\
\hline 60 anos ou mais & $2,204^{*}$ & $2,039^{*}$ & $1,751^{*}$ \\
\hline \multicolumn{4}{|l|}{ ESCOLARIDADE } \\
\hline sem instrução e menos de 1 ano & 0,000 & 0,000 & 0,000 \\
\hline 1 a 4 anos & $0,184^{*}$ & 0,171 & 0,177 \\
\hline 5 a 8 anos & 0,134 & $0,508^{*}$ & 0,176 \\
\hline 9 anos ou mais & $1,460^{*}$ & $1,972^{*}$ & $0,987^{*}$ \\
\hline \multicolumn{4}{|c|}{ POSIÇÃO NA OCUPAÇÃO } \\
\hline empregado com carteira assinada & 0,000 & 0,000 & 0,000 \\
\hline outros empregados. & $-0,818$ & $-0,708$ & 0,006 \\
\hline conta própria & $-0,862$ & $-0,816$ & $-0,450$ \\
\hline empregadores & $-0,207$ & $-0,005$ & 0,144 \\
\hline \multicolumn{4}{|c|}{ HORAS DE TRABALHO } \\
\hline até 14 & 0,000 & 0,000 & 0,000 \\
\hline 15 a 39 & $0,659^{*}$ & $-0,714$ & $-0,285$ \\
\hline 40 a 44 & 0,577 & $-0,842$ & $-0,390$ \\
\hline 45 a 48 & $0,706^{*}$ & $-0,631$ & $-0,042$ \\
\hline 49 ou mais & $1,149^{*}$ & $-0,299$ & 0,203 \\
\hline
\end{tabular}

Fonte: IBGE. Microdados das PNAD de 1992, 1993 e 1995

Nota: Resultados do Procedure GLM/SAS.

Todos os coeficientes assinalados são estatisticamente significativos ao nivel de $5 \%$. 